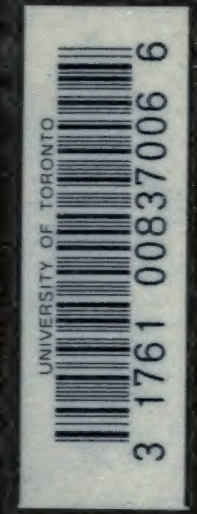



Digitized by the Internet Archive in 2008 with funding from Microsoft Corporation 


37

$370^{4}$. 



\section{Leaders in science}





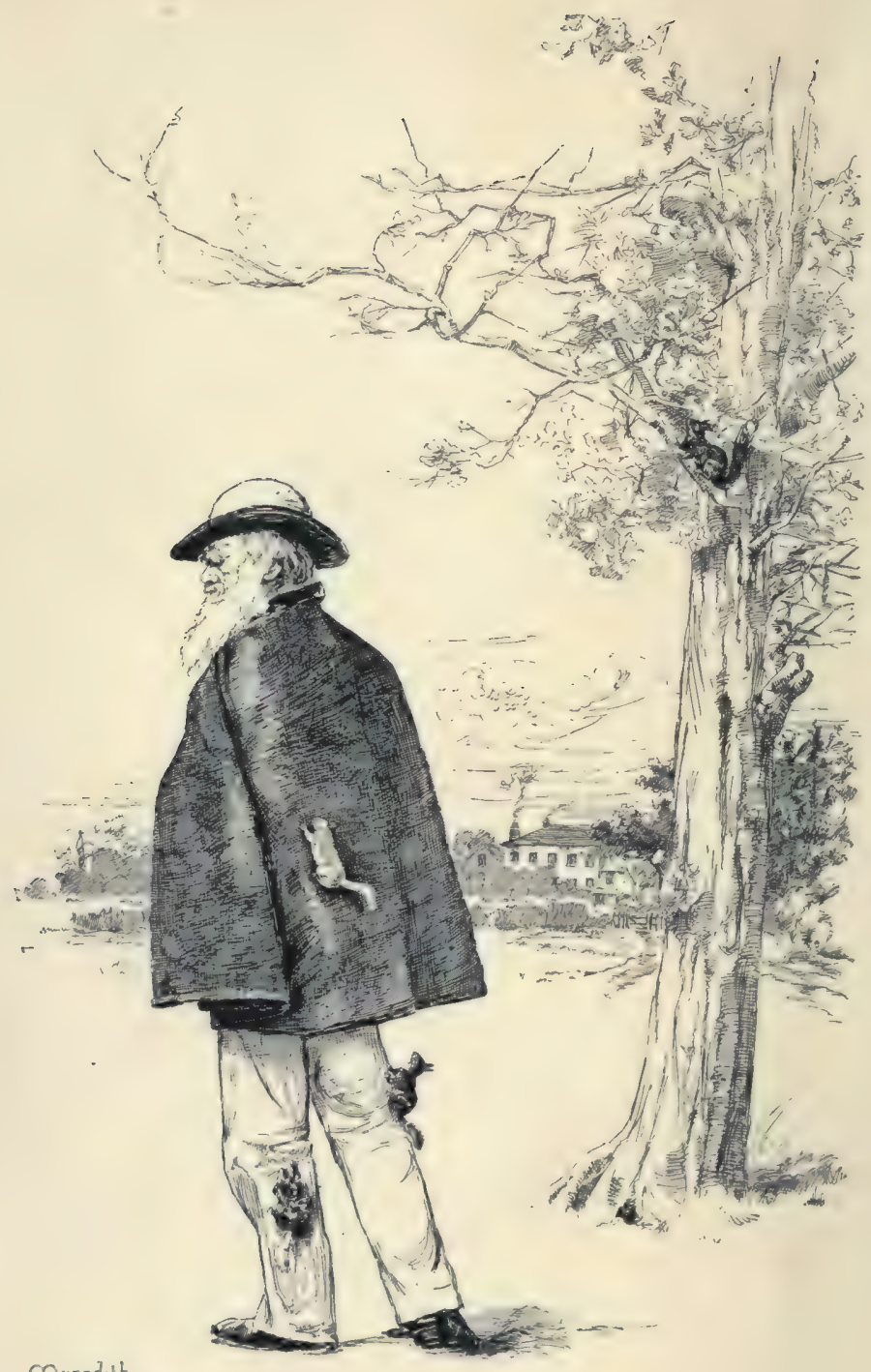

Coredith

DARWIN AND THE SQUIRRELS. 


\title{
Ueaders in Fcience
}

\section{CHARLES DARWIN}

\author{
HIS LIFE AND WORK
}

\section{CHARLES FREDERICK HOLDER}

PBLLOW OF THE N.Y. ACADEMY OF SCIENCES, CORKESPONDING MEMBER OF THE

LINNAAX SOCIETY, RTC., ALTHOR OF " ELEMENTS OF ZOÖLOGY" " " LIVING LIGHTS," "THE IVORY KWWG," "A STRANGE COMPANY," ITC.

G. P. PUTNAM'S SONS NEW YORK LONDON

27 WIST TWENTY-THIRD ST. 27 KING WILLIAM ST., STRAND

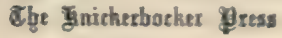




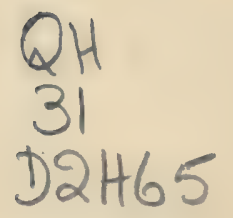

Copyright, 1891

BY

CHARLES FREDERICK HOLDER

$\frac{604311}{18.3 .55}$

The Tenickerbocker press, New york

Electrotyped, Printed, and Bound by G. P. Putnam's Sons 

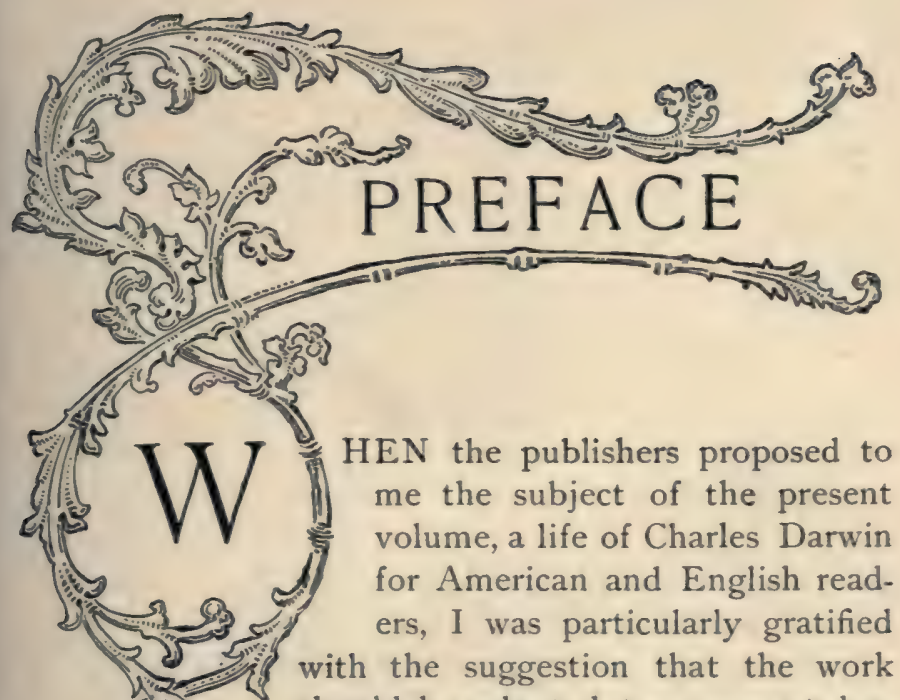

HEN the publishers proposed to me the subject of the present volume, a life of Charles Darwin for American and English readers, I was particularly gratified with the suggestion that the work if should be adapted to young readers 53 as well as old. It has always seemed to me that the life of Charles Darwin was one eminently fitted to be held up as an example to the youth of all lands. He stood as the central figure in the field of natural science in this century, and while it is yet too early to present his life with any approximation of its results upon the thought of the future, it is apparent to every one that his influence upon the intellectual growth of the country, and upon biological science in particular, has been marked and epoch making.

In the preparation of the work I have not attempted an analytical dissertation upon Darwin's life-work, neither have I discussed his theories or their possible effect upon the scientific world, but 
have simply presented the story of his life, that of one of the greatest naturalists of the age; a life of singular purity; the life of a man who, in loftiness of purpose and the accomplishment of grand results, was the centre of observation in his time; revered and honored, yet maligned and attacked as few have been.

I have asked my readers to follow with me the footsteps of the naturalist from school-days in England to foreign shores, seeking to interest them in the pursuits which he loved and to enable them to observe the things which he saw, believing that in this way the remarkable traits of the man as an observer and thinker can be best and most forcibly shown. I have had an object beyond that of simply telling his story, and one which I believe would commend itself to the great investigator were he living: it is, by tracing and following his work and investigations, to encourage young men and women to emulate his methods, become students in the great field of nature, and enjoy the delights of actual contact with the world of which he was an active worker. That such a career is ennobling I trust the following pages will demonstrate.

In the preparation of this volume I am indebted to Francis Darwin, Esq., of Cambridge, England, whose life of his father is the only work extant giving fully the life and letters of the naturalist. My thanks are also due the Biological Society of Washington for the extracts from the Darwin Memorial, which I conceive to be of especial interest to English readers as an expression from the leading 
naturalists of America on the English scientist. My acknowledgments are also given to Professor True, of the Smithsonian Institution, for the loan of a rare and excellent likeness of Darwin, and important papers; and to my wife, whose aid and coöperation have been invaluable.

C. F. H.

Pasadkna, Cal., November r, 1890. 



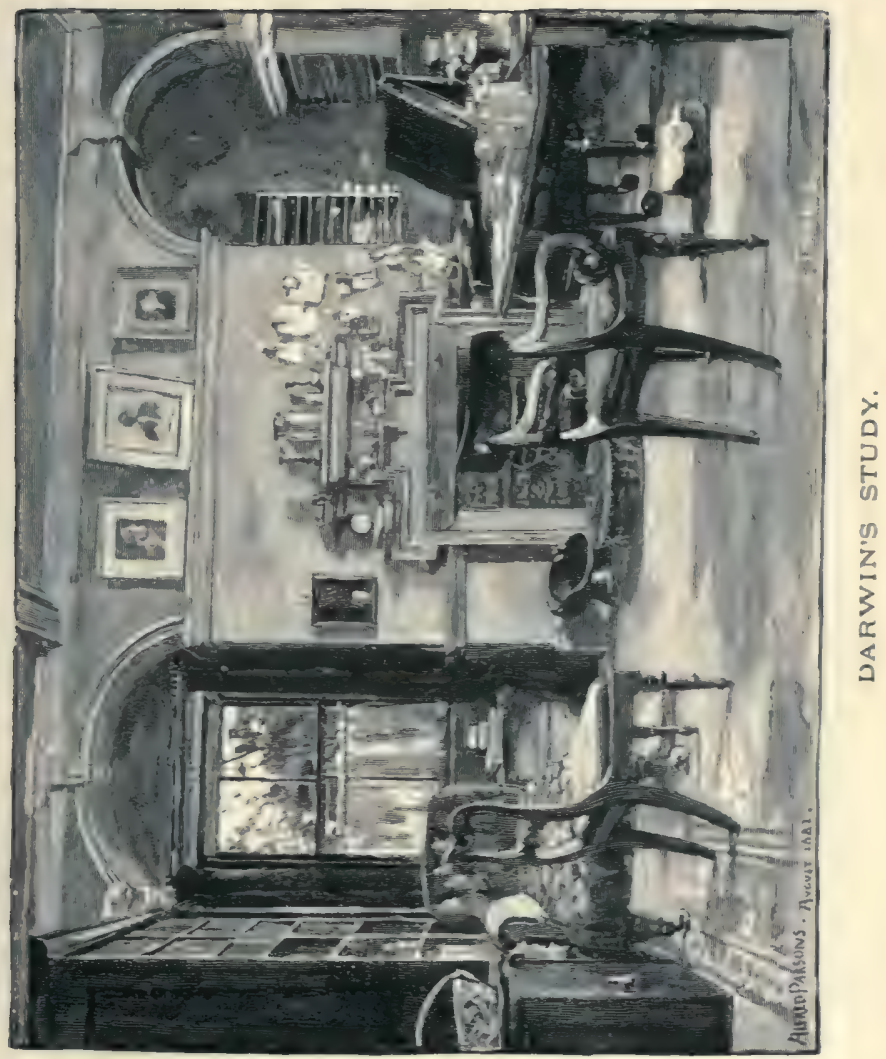





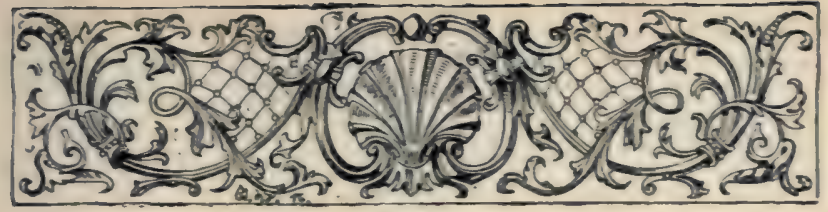

\section{CONTENTS.}

\section{CHAPTER I.}

The First Paper-Taste for Natural History-BirthplaceEarly School-Days-Religions Nature-Books Which Influenced Him-Associates-Introduction to Scientific MenTaste for Sport.

\section{CHAPTER II.}

COLLEGE DAYS .

College Life-Thoughts of Entering the Church-A Poor Mathematician - Beetle Collecting-First Appearance in Print-Associations with Eminent Men-Scientific Reading -Favourite Authors-Interest in Geology.

\section{CHAPTER III.}

\section{THE YUUNG NATURALIST .}

The Beagle-An Offer of Importance-The Young Naturalist-The Voyage-Powers of Observation-Cape Verd Islands-Tours of Investigation-Dust-Showers-Wonderful Phenomena-Geological Studies-St. Paul's Rocks-Fernando de Noronha. 
CHAPTER IV.

IN SOUTHERN SEAS . . . . . . 31

The Log-Book-Bahia-Singular Appearance of the Water -The Vampire Bat-Slavery-Trips into the CountryRare Collections-In the Brazilian Forest-Shooting Monkeys-The Click of a Butterfly-Jumping Spiders-Electrical Displays-The Plata.

\section{CHAPTER V.}

IN THE LAND OF THE SACRED TREE .

The Rio Negro-Trips into the Interior-The Sacred Tree -Superstition of Natives-Salt Lakes-Bahia Blanca-A Tomb of Giants-The Mylodon Darwinii-The Armadillo - Hibernation-Careful Work-War-General Rosas-Brutal Natives-Skilled Equestrians.

\section{CHAPTER VI.}

AMONG THE FOSSILS .

A Long Bullock Ride-Santa Fé-An Animal CollectorLarge Fossils-Indian Superstitions-Darwin Ill-A Native Doctor-Geology-Gigantic Armoured Animals-DroughtThe Parana-The Jaguar-Darwin a Prisoner-Swimming Horses-Shower of Butterflies-Phosphorescence.

CHAPTER VII.

THE LAND OF GIANTS

The Patagonians-Guanaco Hunting-Singular Burial Customs-A Horse with a Proboscis-Extinction-Up the Santa Cruz-Puma Tracks-Catching the Condor-Falkland Islands-Among the Glaciers-The Fuegians-Giant SeaWeed and Its Work.

CHAPTER VIII.

THE FOOT OF THE ANDES.

At Valparaiso-Andean Life-An Old Schoolmate-An 
Ocean Bottom-In the Mines-Hot Springs-Darwin Excites Suspicion-Volcanoes-Tame Birds-The Myopotamus-Predaceous Gulls-Birds Killed by Them.

\section{CHAPTER IX.}

IN THE EARTHQUAKE COUNTRY

At the Bay of San Carlos-Earthquakes-Destruction of Concepcion-At Talcahuana-Tidal Waves-Poverty of the Victims-Elevation of the Coast-Darwin's Coolness in Danger-Narrow Escapes.

\section{CHAPTER $\mathrm{X}$.}

IN THE RED SNOW COUNTRY

Valparaiso-The Portillo Pass-Land of the Red SnowElectrical Conditions-A Swarm of Locusts-Experiments with the Reduvius-A Forest of Stone-Valley of the Copiapó-Ruins at Old Callao-Antiquity of Man.

CHAPTER XI.

AMONG THE OCEAN VOLCANOES

Galapagos Islands-Number of Craters-Gigantic Tortoises-Land and Marine Lizards-New Marine FormsFlora-Number of Cryptogamic Plants-Variety of Forms on the Different Islands-Tameness of the Birds.

\section{CHAPTER XII.}

IN THE GARDENS OF THE SEA.

Keeling Island-Among the Corals-Towed by a TurtleSagacity of the Birgos-Stinging Corals-Coral-Eating Fish -Theories Regarding Reef Structure-Mauritius-Extinction of Animals at St. Helena-Return to England. 
CHAPTER XIII.

DARWIN THE NATURALIST

Ambition of Darwin-Future Work Decided upon-Scientific Friends-Papers Read before Various SocietiesExperiments with Farthworms-Marriage of DarwinMethods of Work-Various Publications.

CHAPTER XIV.

\section{HOME LIFE}

Appearance of Darwin-Continued Ill-Health-Daily Habits-Change in Musical and Literary Tastes-Affection for His Children.

\section{CHAPTER XV.}

THE WORK OF A LIFE

Early Papers-Publications by Scientific Societies- "The Formation of Mould"- "The Cirripedia"-The Wallace Incident-Collecting Material for the "Origin of Species" - Success of the Work-Time Spent in Authorship-Religion-Final Work and Death.

\section{CHAPTER XVI.}

Membership in Societies-The Institute of France-Prizes, Medals, Degrees, Portraits, Gifts, etc.

\section{CHAPTER XVII.}

\section{THE DARWIN FAMILY}

The First Known Darwin-The Head of the FamilyNatural-isistory Tastes-Poets, Doctors, and Military Men -Erasmus Darwin-Carlyle's Description of ErasmusEvidences of Genius. 


\section{CHAPTER XVIII.}

\section{DARWINISM}

The Coining of the Word-What it Means-Its Relation to Evolution-" The Survival of the Fittest "- "The Struggle for Existence"-The Descent-Examples of Evolution.

\section{CHAPTER XIX.}

DARWINISM CONTINUED

How Change is Produced-Vast Eras of Time-The Age of the Earth-Evidences of Evolution-Extinct Animals.

\section{CHAPTER XX.}

THE DARWIN MEMORIAL . $\left(-1+n^{2}\right.$

Addresses by American Scientists: Dr. Theodore Gill-W. H. Dall-Major John W. Powell-Richard RathbunCharles V. Riley-Lester F. Ward-Frank Baker-Frederick W. True.

\section{APPENDIX}

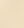

List of Works by Charles Darwin-List of Books containing Contributions by Charles Darwin-List of Scientific Papers, including a Selection of Letters and Short Communications to Scientific Jouruals-Works on Darwinism for Further Reference.

INDEX

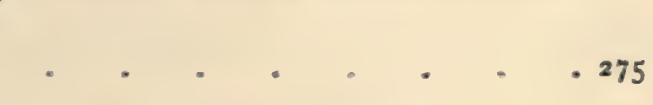





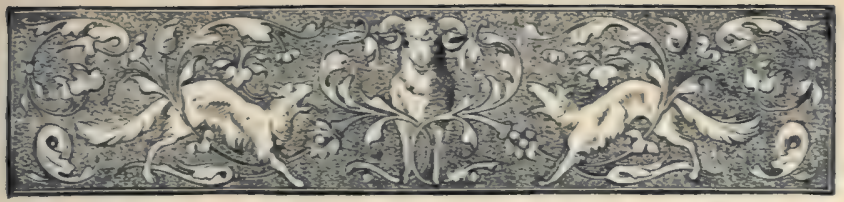

ILLUSTRATIONS.

PAGB

DARWIN AND THE SQUIRRELS . . . Frontispiece ST. PAUL'S ROCKS FROM THE EAST-From Spry's "Voyage of the Challenger" . . . . 24 SHARK FISHING AT ST. PAUL'S KOCKS-From Gosse's

"Romance of Natural History" . . . . 26 A BRAZILIAN COLLECTING-GROUND-From Gosse's

"Romance of Natural History" . . . 28 PORCUPINE FISH (DIODON) FLOATIXG ON THE SURFACE

DARWIN FINDING A VAMPIRE BAT BITING A HORSE, 32 BRAZILIAN HUNTERS AND ANIMAL COLLECTORS • 36 SOUTH AMERICAN NATIVE HUT OF LEAVES • . 38 A PLANTER'S HOUSE IN BRAZIL . . . . 40 A HOME ON THE PARAHIBA RIVER, BRAZIL • • 42 CAMP IN A BRAZILIAN FOREST . . . . . . 44 SOUTH AMERICAN OSTRICH (RHEA) AND YOUNGFrom Brehm's "Natural IIistory" . . . 50 SOUTH AMERICAN OSTRICHES FORDING A RIVER 52 NATIVE AUSTRALIANS HUNTING THE EMU-From Figuier's "Birds" . . . . . . . 54 
DIAGRAM ILLUSTRATING THE EVOLUTION OF THE HORSE

THE PATAGONIAN CAVY-From Brehm's " Natural History" . . . . . . . 74 THE CAPYBARA-From Brehm's "Natural History " 76 DARWIN SHOOTING AT A CONDOR . . . 78 CAPE FROWARD, STRAITS OF MAGELLAN-From Spry's "Voyage of the Challenger" . . . 80 MUD VOLCANOES, TURBACO, SOUTH AMERICA-From Figuier's "World before the Deluge" . . 90 BARK-GATHERERS' CAMP IN PERU-From Figuier's "Vegetable World". . . . . . ELEPHANT TORTOISE, GAIAPAGOS ISLANDS-From Brehm's "Natural History" . . . . 106 DARWIN TESTING THE SPEED OF AN ELEPHANT TORTOISE (GALAPAGOS ISLANDS) • . . I08 A CORAL ISLAND, OR A TOLL-From Figuier's" Ocean World" . . . . . . . . 112 BIRGOS, OR COCOA-NUT CRAB . . . . . II4 DARWIN'S STUDY-From "The Century Magazine" I 28 PORTRAIT UF CHARLES DARWIN-From" The Century Magazine" . . . . . . . . . . I50 COLLECTING IN THE SARGASSO SEA . . . . I I6 


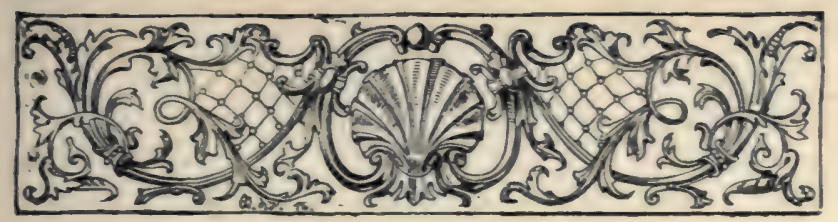

\section{CHARLES DARWIN.}

\section{CHAPTER I.}

THE BOY DARWIN.

The First Paper-Taste for Natural History-Birthplace-Early School Days-Religious Nature-Books Which Influenced Him -Associates-Introduction to Scientific Men-Taste for Sport.

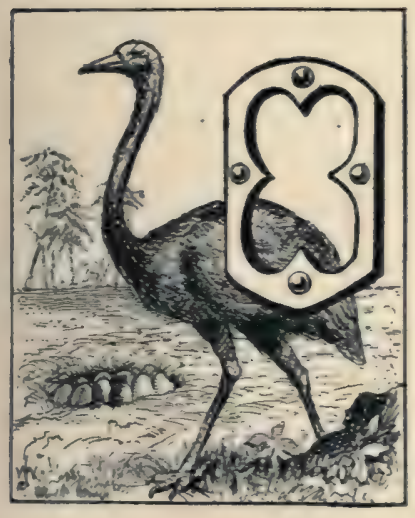

$\mathrm{NE}$ evening, in the year I826, a tall, slender youth rose at a meeting of the Plinian Society of Edinburgh, and with some embarrassment and hesitation unfolded a paper and addressed the chair.

The speaker was Charles Darwin, and this was his first public attempt to convey to others information which he had acquired regarding natural objects. At this time Darwin was seventeen 
years of age; yet his paper, which was on the common Flustra, or sea-mat, attracted no little attention, and was the first in an ever increasing series that gave him in later years a world-wide reputation.

While this was Darwin's first public appearance as a naturalist, he had long been an ardent collector. When but nine years of age he was the happy possessor of a collection of seals, franks, coins, and minerals which were the admiration of his young friends and acquaintances.

Our hero was born at Shrewsbury in 1809 , and began his school-boy life at a day-school, later, in I8I 8, attending the large establishment of Dr. Butler, a mile from the old homestead. This school, like many of the time, was a strictly classical institution, where the young mind was regaled with ancient geography and history almost exclusively. The lessons, so he tells us, were "learned by heart," with interminable verses, - a feature much esteemed by educators of the day, and were mastered in boyish fashion by a combination of the talent of the school. $\mathrm{He}$ was singularly deficient in language, yet possessed, like other members of his family, a remarkable memory, so that, as he writes in his quaint Autobiography: "Much attention was paid to learning by heart the lessons of the previous day; this I could effect with great facility, learning forty or fifty lines of Virgil or Homer whilst I was in morning chapel ; but this exercise was utterly useless, for every verse was forgotten in forty-eight hours."

Our young hero, while manly and thoughtful, was simple-hearted, and often a victim to the deceptions 
practised by boys upon each other. Among his comrades was a boy named Garnett, who one day invited young Darwin into a store and treated him to cakes. Darwin noticed that his friend did not pay for them, and the occurrence, so unusual, moved him to ask for an explanation. Mischievous Garnett eyed his young schoolmate a moment, much as $\mathrm{Mr}$. Jingle did Mr. Pickwick on their famous ride, and replied: "Why, my uncle left a large sum to each tradesman in the town with the understanding that anyone who wore his old hat and moved it in a peculiar way should obtain what he wished free." Young Darwin was naturally seized with a burning desire to exercise this wonderful power, which his comrade was only too eager to grant; so the next store they came to Darwin took the hat, walked bravely in, and ordered a supply of good things, giving the old hat a move as directed. He was passing out, when the storekeeper, who was at first amazed, dashed over the counter after the singular customer, who stood not upon the order of going, but dropped hat and cakes and ran as if for his life to the measure of the hearty laughter of his companion.

While Darwin was fond of sport and a true boy in his pranks and games, there was a vein of unconscious dignity in him that the average youth did not possess. He tells us that in running to school he prayed to the Lord to aid him in arriving before it was too late, which would show a strong religious nature; and that he was humane and honourable to a marked degree is well known. How many boys in 
collecting eggs think of the rights of the birds? Yet our young naturalist, while an indefatigable collector of birds' eggs and nests, was invariably careful to take but one egg from each nest,--recognising in this the rights of the lower animals. His humanitarian ideas were carried to what some would consider extremes; thus, hearing at his uncle Josiah Wedgwood's, that it was cruel to spit living worms, he - killed them first by a bath of salt and water.

As a boy he was fond of solitary walks, and often rambled away by himself, loving the quiet seclusion of the forests, the haunts and fishing-pools at Maer, or the old fortifications about Shrewsbury. At such times he frequently became lost in meditation, so that in one instance, while deeply absorbed, he walked over a parapet, falling a distance of seven or eight feet. In referring to this, he naïvely remarks : "The number of thoughts which passed through my mind during this very short, but sudden and wholly unexpected, fall was astonishing, and seem hardly compatible with what physiologists have, I believe, proved about each thought requiring quite an appreciable amount of time."

The young naturalist early developed habits of observation, and entered into investigations, especially of difficult and complex subjects, with an ardour and interest that was infectious. He experienced intense pleasure in geometrical problems, enjoying the reasoning that was involved, and showed marked evidence of the care and patience in attaining certain ends that produced such results in his later career. The books which influenced his 
boyish mind were Horace, certain odes of which appear to have been the one bright feature in his school life; many hours were spent poring over the historical plays of Shakespeare, while the poetry of Byron and Scott, and especially Thomson's "Seasons," seem to have given him pleasure and satisfaction. A book that had a strong influence upon him was the "Wonders of the World," over whose varied contents he often pored, discussing the strange facts set forth with his companions. Small things often have much to do in shaping our lives, and in this volume we undoubtedly find the germ that excited in his mind the love for travel and exploration which ultimately resulted in the famous voyage which he made around the world in the Beagle. Darwin testifies to the correctness of this, and in later years, in referring to the book, wrote to a German publisher: "I believe that this book first gave me a wish to travel in remote countries, which was ultimately fulfilled by the voyage of the Beagle."

While we may trace the love of travel to hours spent over this volume, his passion for natural history was accelerated by White's "Selborne." From its pages he obtained his fondness for birds, learning to note their ways and habits, and becoming an ardent ornithologist.

Darwin had a decided natural inclination to literature of a scientific character. He read during these days several books on chemistry, and worked with his elder brother in his laboratory, making gases and various other chemical compounds; and that it was an unusual taste among the boys of the time is 
shown by the fact that he was nicknamed "Gas" by his fellows, while even the head-master rebuked him for wasting his time upon subjects that could be of no possible use to him in later life. The opinions of this teacher seem to have been entertained by Darwin the elder, who, concluding that our hero was accomplishing little at the school, took him away in October, I825, and sent him to the University of Edinburgh to study medicine. Unfortunately, Darwin now discovered that his father was a wealthy man, and, being of an argumentative mind, he failed to see that it was necessary for him to make any especial exertion when he was certain of coming into a goodly heritage. It is interesting to note this resolution-notably, not an evidence of ambition or lofty ideas - appearing in a life whose history in later years is marked by its high and lofty aims and fixity of purpose.

Darwin entered the University of Edinburgh, where his brother was studying, without ambition, and, like many boys, drifted with the current. $\mathrm{He}$ found the lectures, with the exception of those on his favourite chemistry, dull and uninteresting, while those on materia medica by Dr. Duncan he describes as something fearful to remember in their dullness. The subjects were distasteful to him, causing him to neglect dissection, which in later years he appears to have greatly regretted, being an absolute necessity in the elaborate and minute investigations that formed his life-work. Despite his lack of interest as a student he obtained patients, and, in all probability, would have succeeded under the tutelage 
of his father, an eminent physician, had not a painful operation in the hospital at Edinburgh practically ended his career in medicine, as he tells us that he bore it as long as he could, and then rushed from the room ; the scene, which was enacted before the days of chloroform, haunting him for years. This is suggestive of the extremely sympathetic temperament of the boy Darwin; his entire nature was one of tenderness, not only to his companions, but to all living things. While his school days were not resulting in any apparent accumulation of knowledge in the lines indicated by the curriculum, we find the love of natural history steadily growing.

He was an ardent collector of minerals; and the love for insect studies, which he developed when but ten years of age, down by the sea-shore in Wales, was one of the delightful memories in later life. At Edinburgh he found congenial friends in young men who were interested in natural science, and the associations and friendships then formed had no little influence in shaping his future career. Here he met Ainsworth, who afterwards became a famous geologist, and wrote a book on Assyria; Dr. Coldstream, a writer on zoölogical subjects; and Hardie, who was a promising botanist. Of all the friends made at this time, perhaps Dr. Grant exercised the greatest influence over him. With this zoölogist he made many trips to the sea-coast, became familiar with the methods of current investigation, and it was during these days that the observations regarding the Flustra, mentioned in the beginning of this chapter, were made. Dr. Grant referred to Darwin's investigations 
in his memoir on the Flustra, in which our young naturalist saw his name for the first time in print. Dr. Grant introduced him to many persons interested in science, and invited him to the meetings of the Royal Medical Society, where, according to Darwin, "much rubbish was talked." Dr. Grant also took him to the Wernerian Society, where he listened to Audubon, who was then in Europe in the interests of his great work on birds, and who read several papers before the Society. These days were rich in future promise for the young student, all his associations being such as to increase his interest in science. He enlarged his acquaintance on all sides, took lessons in taxidermy, with a man who had travelled with Waterton, and with Mr. Leonard Horner visited the Royal Society of Edinburgh, where he listened to Sir Walter Scott, who was at that time its president. The proceedings produced a profound impression, shown by his statement in later years: "If I had been told at that time that I should one day have been thus honoured (with membership), I should have thought it as ridiculous and improbable, as if I had been told that I should be elected King of England."

Darwin's taste for science was supplemented by a course of studies, and in his second year he attended a series of lectures on geology and zoölogy, those in the former making a decided impression upon him, as he says : "The sole effect they produced on me was the determination never, as long as I lived, to read a book on geology." In other words, the lecturer had the unhappy faculty of making sub- 
jects naturally of interest exceedingly dry. While the lectures of this instructor were of no especial advantage, they were the means of his meeting $\mathrm{Mr}$. Macgillivray, the curator of the local museum, who in after years wrote a work on Scottish birds, and was an enthusiastic naturalist.

During the long-vacation period Darwin threw aside his books, and with some congenial friend took long walks over the country, enriching his mind by personal contact with nature, thus building up the taste for investigation which formed so prominent a feature in his after-life. These walks were something more than would be attempted by the average American school-boy. He thought nothing of covering thirty miles in a day; and, during the summer of 1826 , with two friends, with knapsack on back, he travelled over a large part of Wales, later going over the ground again with his sister, that she might be a participant in his enjoyment.

After the summer trips the autumn was generally passed at Mr. Owen's, at Woodhouse, or at his uncle Josiah Wedgwood's, at Maer, where he found opportunity to indulge in shooting, which was as much a passion with him as collecting minerals or insects. Days were spent on the heath and among the Scotch firs, following the gamekeeper after black game, and no young American trout fisherman kept a closer record than did our sportsman naturalist. Every bird shot during the season was carefully noted,- - a fact which shows the method, thoroughness, and detail that marked every subject in which he was interested. His care to 
credit himself with the results of his skill was often the subject of practical jokes on the part of his friends, and he relates the following: "One day, when shooting at Woodhouse with Captain Owen, the eldest son, and Major Hill, his cousin, afterwards Lord Berwick, both of whom I liked very much, I thought myself shamefully used, for every time after I had fired, and thought that I had killed a bird, one of the two acted as if loading his gun, and cried out, "You must not count that bird, for I fired at the same time,' and the gamekeeper, perceiving the joke, backed them up. After some hours they told me the joke, but it was no joke to me, for I had shot a large number of birds, but did not know how many, and could not add them to my list, which I used to do by making a knot in a piece of string tied to a button-hole; this my wicked friends had perceived."

As enthusiastic as he was, Darwin had some doubts in his mind as to whether such excessive zeal was to be commended, and we find he argued with himself on the question, quieting his doubts at one time by assuming and almost convincing himself that the perfection to which he had attained was really an evidence of high intelligence on his part. The fact that he could find game when no one else could, and manage the dogs with consummate skill, seemed to his mind sufficient reason for pursuing the pastime.

At Maer he met many distinguished people, and in the home of the famous Wedgwood there was an air of refinement and culture most valuable in rounding and shaping the ideas of so thoughtful and 
clever a youth. Here he made the acquaintance of Sir J. Mackintosh, whose well-known conversational powers appear to have impressed the young naturalist, and that the elder man foresaw something in his young friend may be surmised from his remark, long remembered by Darwin: "There is something in you that interests me." In these boyhood days we see many qualities that Darwin himself modestly disclaims : a steadfastness of purpose, a perceptive faculty, and demand for something beyond the limited educational facilities of the day. His actual schooling may be said to have been a failure, as he neglected the dry classical studies or forgot them; yet the lessons he drew from the broad field of nature were well learned and never forgotten.

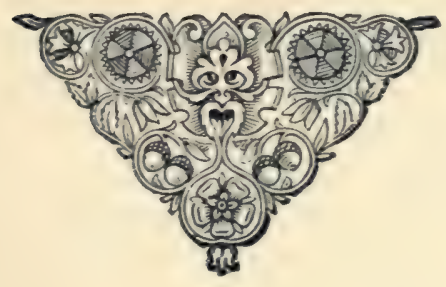




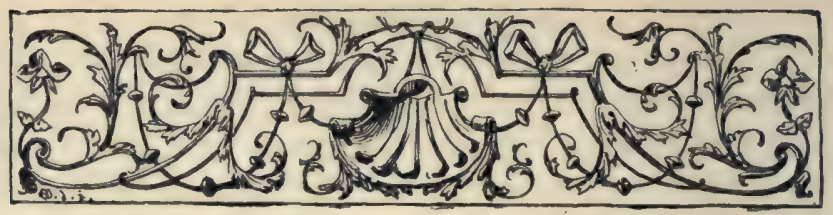

\title{
CHAPTER II.
}

\author{
COLLEGE DAYS.
}

College Life-Thoughts of Entering the Church-A Poor Mathematician-Beetle Collecting-First Appearance in Print-Associations with Eminent Men-Scientific Reading-Favourite Authors -Interest in Geology.

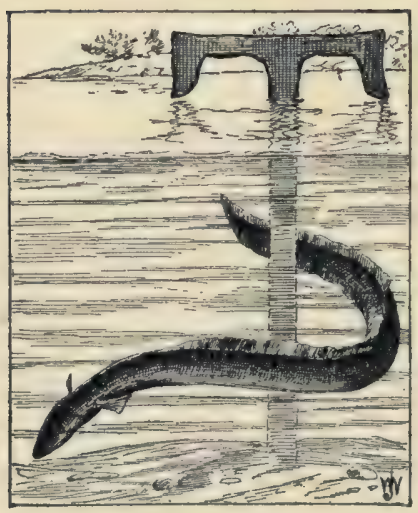

$\mathrm{HE}$ college life of Darwin constitutes one of the epochs of his career, as during these days, so happy in their memory, occurred many of the incidents that shaped his future. $\mathrm{He}$ entered college in 1828 , this movement being the result of a decision on the part of his family, that as he had failed as a doctor, he might possibly be induced to enter the Church. This proposition was made to the young man, who asked time in which to consider, during which deliberation he read attentively several religious works, including "Pearson on the Creed," and questioned himself thoroughly as to his 
beliefs and disbeliefs. He confesses to having some scruples about accepting all the dogmas of the Church, but as he believed in the Bible implicitly and literally, he soon satisfied himself that he could accept the creed without any reservation. In referring to this interesting period in his life, Darwin in his Autobiography says that years after a German psychological society sent for his photograph, and after much discussion reported that he had the bump of reverence developed enough for ten priests; so that it might be assumed that he was well equipped by nature for order taking.

Darwin, however, was not destined for the Church, though he entered Cambridge with this purpose in view, and took up a course of studies which would give him the desired degree. He found that he had forgotten his Latin and Greek, which necessitated work with a private tutor, so that he did not enter college until Christmas of the year 1828 .

As far as academical studies were concerned we learn that his three years' work here was almost a perfect blank. Mathematics was never mastered without extreme difficulty - a fact which he emphasised in a letter written to Dr. J. B. Holder, father of the author, some years ago, when the two were discussing the flight of birds. So difficult was it for Darwin to master this study that he was almost discouraged, and in referring to it he says: "I do not believe that I should ever have succeeded beyond a very low grade." Though the young student may have lacked application it is evident that he acquired information very readily, as, while confessing what 
might seem unusual indifference, he took the degree of B.A. without apparent exertion. At this time he read such works as Paley's "Evidences of Christianity" and "Moral Philosophy," and the thoroughness of his reading may be judged from the fact that he could have written out from memory almost the entire former work. This course of reading, without the demand for memorising, which was a part of the educational methods in former years, he conceived to be the only part of the academical course of any actual advantage to him. There were several lectures in the course, but those by Professor Henslow, on botany, were the only ones he attended. The walks and strolls with this naturalist in search of rare plants and flowers were highly enjoyed, and what proved a life-long friendship was begun. During the college days his love for natural history was steadily increasing. He was now especially interested in the study of beetles; not to dissect them, but for the simple delight of possessing great numbers and comparing them one with another, and his collection was a large and really valuable one. How enthusiastic he was may be seen from the following incident: In ripping down the bark from an old tree he saw two rare beetles, which he captured, one in each hand. Just then out ran a third, equally rare and beautiful; but what was to be done? There was no time for deliberation, so he put one beetle in his mouth, thus freeing a hand to seize the fleeing prize; but the second beetle, objecting to this unceremonious treatment, emitted a secretion so bitter that he was forced to eject it, losing in the confusion of the attack two of the insects. 
Darwin was an indefatigable collector, and having an ample allowance was enabled to give full bent to his tastes and inclinations. He collected in a most systematic manner, following methods of his own devising. He employed a workman, who spent his time during the winter in scraping the decayed moss from trees and in collecting suitable material from various sources, all of which was placed in a bag and brought to the young naturalist, who in this way found many rare and choice specimens.

Of the delights of this study Darwin was fond of talking, and in his Autobiography he wrote: "No poet ever felt more delighted at seeing his first poem published than I did at seeing, in Stephen's 'Illustrations of British Insects,' the magic words, 'captured by C. Darwin, Esq.' "

Our hero had as a companion during his college days a cousin, W. D. Fox, a Christ's-College man, who encouraged him in his studies and introduced him to a number of well-known naturalists. Here he met Albert Way of Trinity, who in after years became a distinguished archæologist. He was intimate with Whitley, Senior Wrangler, afterwards Hon. Canon of Durham, who, being a man of refined and cultivated tastes, influenced the young man for the best and inculcated in him a love for the beautiful in art, as well as nature. Whitley became his guide and censor to a certain extent, and trips were made together to the various art galleries, where Darwin, through observation and talks with his friend and the curator, acquired a good knowledge of the standard and various schools of art. This taste, he tells us, was not a natural one, and was perhaps in 
accord with his fondness for music at this time, though he was not a musician and could not distinguish harmony from discord.

I have said that the college life of Darwin constituted one of the important epochs in his career; this was mainly due to his acquaintance and ultimate friendship with Professor Henslow, the naturalist. He was presented to the latter by his cousin already alluded to, and went weekly to his house, which was the acknowledged centre of scientific interest. The intimacy increased, and Darwin soon became his constant companion during walks and strolls, when we may naturally suppose that the conversation turned on natural history. Professor Henslow was one of the best-posted men of his time in geology, botany, and the various branches of science. $\mathrm{He}$ was also a close investigator and, according to Darwin, extremely fond of drawing conclusions from long-continued and minute observations.

If there is one feature more than another in the life of Darwin that impresses the reader it is the time he spent in careful investigations, and the thoroughness which characterised all his scientific work, and that his methods, which were so eminently successful and telling, were the result of this companionship to a great extent there can be no doubt. Darwin himself says: "My intimacy with such a man ought to have been, and I hope was, an inestimable benefit."

This intimacy with Henslow naturally enlarged the young man's scientific acquaintance, among whom were Dr. Whewell, a man of distinguished attain- 
ments, and a conversationalist ranked by Darwin next to Sir John Mackintosh; Leonard Jenyns, a well-known zoölogist, who in later years was associated with Darwin in scientific work; Mr. Ramsay, a brother of Sir Alexander Ramsay, and many more with whom he was thrown in more or less intimate relationship, which must have had an effect upon his character and tastes. The young man at this time must have shown many evidences of the brilliant future that was before him. Older men sought his company and listened to his ideas and views, and he was an acceptable companion in their walks and excursions. His college mates must also have recognised his talents in the direction of science, as one of his companions, after watching him at work at his insect collection, volunteered the prophecy, which seemed to Darwin preposterous, that one day he would be a Fellow of the Royal Society. In his last year at college the young naturalist took up a course of scientific reading, which had no little influence in determining his career. Humboldt's "Personal Narrative" was read and discussed, exciting in his mind a desire to travel, while Herschel's "Introduction to the Study of Natural Philosophy " created a strong wish to indulge in original investigation and to become one of the scientific workers of the world. These works so interested him that he copied extracts which he read to his friends while on their expeditions, and Humboldt's description of the beauties of Teneriffe excited so intense a desire to see the island that he was about negotiating for a passage when another plan prevented. 
Step by step Darwin advanced in scientific learning. The vacation days were devoted to beetlecollecting, while the shooting season in the autumn, a sport to which he was passionately attached, as has been shown, gave him an opportunity to study the larger forms.

In his last college days, or in I831, Henslow had so interested him in geology that he took up the study and began a systematic investigation of the local rocks. He examined sections, made maps, and finally, in the summer of this year, undertook a geological tour through North Wales with Professor Sedgwick, which proved of inestimable value in later years.

In this period we see that the taste and love for natural science are uppermost in our hero's mind and steadily developing,- the natural preparation which ultimately culminated in producing the greatest scientist of the age.

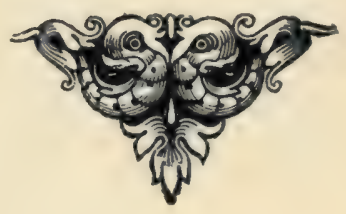




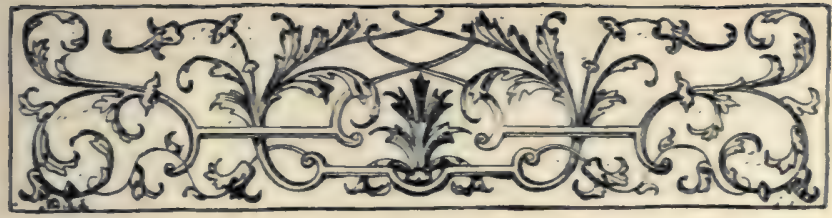

\section{CHAPTER III.}

THE YOUNG NATURALIST.

The Beagle-An Offer of Importance-The Young Naturalist-The Voyage-Powers of Observation-Cape Verd Islands-Tours of Investigation-Dust-Showers-Wonderful Phenomena-Geological Studies-St. Paul's Rocks-Fernando de Noronha.

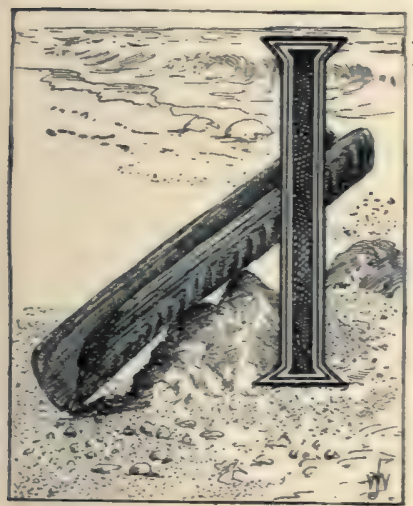

N I83I the British Government decided to send out a well-equipped vessel to complete the survey of the South American coast, begun by Captain Shaw some years previous. The vessel selected for this work was the Beagle, a six - gun brig, and Captain Fitz-Roy of the Royal Navy was given the important command. An enthusiast in science, Fitz-Roy conceived the idea of taking a naturalist with him to study the fauna and flora of the different countries he might visit, and in his search for a competent person he wrote to Professor Henslow, who, in turn, made the offer to Charles 
Darwin, who had just graduated from Cambridge. The latter returned from a geological trip to find the communication, and to say that he was delighted but faintly expresses it. He determined to accept should his father not object, but, unfortunately, the latter looked with great disfavour upon the plan. He finally said that he would give his consent if his son could find a sensible person who would encourage it.

Young Darwin very reluctantly gave up what appeared to him a veritable dream of promise and an opportunity to make for himself a scientific career. As good-fortune would have it he mentioned the matter to his uncle, Josiah Wedgwood, who offered to undertake the rôle of one sensible person, and as a result the elder Darwin relented and the position was accepted. This step was the beginning of a new epoch in the life of the young naturalist. It was, as he says, by far the most important event of his life, and in a letter to Captain Fitz-Roy he wrote: "What a glorious day the 4 th of November will be to me! My second life will then commence, and it shall be as a birthday for the rest of my life."

After many delays attendant upon fitting a large ship for a long voyage, the Beagle put to sea, and the expedition, which had so material an effect, not only upon Darwin, but upon preconceived ideas of many natural-history questions, began.

The Beagle was what we now term a barque, and of two hundred and thirty-five tons burthen. She represented a class facetiously known as coffins by 
the men, from the fact that many of her type had gone down in heavy gales. She was fairly well equipped; had a crew of thirty-five men, and was fitted with all the conveniences that one might expect to find at this time. Young Darwin went as a volunteer; he paid his own expenses, and was to mess with the captain; so that the voyage began under pleasant auspices and with the promised companionship of a man who was fully interested in science and in complete sympathy with his aims and ambitions.

Darwin was at this time in the full flush of manhood; in every way a delightful companion, and essentially a man to make friends and keep them. His tender and lovable nature, consideration for others, and evident desire to share with all the hardships which really could have been avoided, did not fail to create for him the warmest friends not only on shipboard, but wherever he went. An idea of the ship life has been given by Admiral Lord Stokes in the London Times of April 25, I883:

"May I beg a corner for my feeble testimony to the marvellous persevering endurance in the cause of science of that great naturalist, my old and lost friend, Mr. Charles Darwin, whose remains are so very justly to be honoured with a resting-place in Westminster Abbey?

"Perhaps no one can better testify to his early and most trying labours than myself. We worked together for several years at the same table in the poop-cabin of the Beagle during her celebrated voyage, he with his microscope and myself at the charts. 
It was often a very lively end of the little craft, and distressingly so to my old friend, who suffered greatly from sea-sickness. After perhaps an hour's work he would say to me, 'Old fellow, I must take the horizontal for it,' that being the best relief position from ship motion; a stretch out on one side of the table for some time would enable him to resume his labours for a while, when he had again to lie down.

"It was distressing to witness this early sacrifice of Mr. Darwin's health, who ever afterwards seriously felt the ill-effects of the Beagle's voyage."

In following our hero on his long voyage the reader cannot fail to be impressed with two things: his remarkable powers of observation, and the care and patience with which he made his investigations and consequent deductions; and when it is borne in mind that the investigator was still a very young man fresh from college, the nature of his observations and the comprehensiveness of the ground covered will appear more remarkable. Darwin, as we have seen from the letter of Admiral Stokes, was a victim to sea-sickness, and, curiously enough, it clung to him with unrelenting pertinacity during the entire voyage. After an uneventful trip the Cape Verd Islands were reached, where the young naturalist for the first time found himself in a tropical field. St. Jago, the largest island of the group, was the first examined; here he saw actual volcanic effects, barren rocks, a torrid sun, and deep groves of graceful bananas and cocoa-nuts. The barren stretch of rocks and denuded portions of the island attracted his attention, and investigation showed that it was due partly to 
human intervention, the trees having been cut away and destroyed, thus allowing the rains to wash down quickly, leaving the island almost sterile in parts.

Many expeditions were made over the island: one to the town of Ribeira Grande, where a fine old ruin, a cathedral and fort were found, the former containing many objects of interest dating back to the sixteenth century. The dignitaries of the church were buried here, and Darwin noticed one tombstone which bore the date 1497 , five years after the discovery of America, and three after that of the islands.

The atmosphere of St. Jago was, as a rule, hazy, and here our young naturalist made some observations which created much interest among scientific men. Investigation showed him that the haze, which often obscured the mountains, was occasioned by a fall of dust so impalpable and fine that it rested in the air as haze or a very light fog. Some of this was collected and sent back to Professor Ehrenberg for examination, and in 1845 Darwin forwarded an elaborate paper on the subject to the Royal Geographical Society. The dust in some places was offensive, covering every thing and soiling the sails and clothing of the men.

In the course of the voyage pieces larger than the thousandth of an inch square were noticed. Whence came this strange shower? was the question he wished to solve, and the problem could only be answered by a determination of the elements which composed it. This Professor Ehrenberg was enabled to accomplish. He found that the dustshower did not come from the Cape Verd Islands 
but must have originated thousands of miles away. The dust was made up to a certain extent of infusoria-minute fossil forms that could be readily transported by the wind, and Darwin, by the identification of the fossils, was enabled to demonstrate that they had been borne not from the adjacent coast of Africa, but from South America, several thousand miles distant. The shower referred to here was estimated by the young naturalist to have a breadth of sixteen hundred miles and an area equal to one million square miles.

These dust-showers produce what are known as blood-rains in Europe, and Professor Ehrenberg estimated that in one shower over seven hundred and twenty thousand pounds of matter fell, out of which ninety thousand pounds consisted of the remains of minute animal forms.

The dust-shower had a greater significance to our young naturalist than a mere phenomenon, and here we see how his every discovery or observation resulted in a deduction of value to the scientific world. If dust, and such large particles, could be carried vast distances, why not seeds? and he assumed at once that the light and delicate sporules of cryptogamic plants could be transported from continent to continent, - $\mathrm{a}$ thought which in later years he elaborated with interesting and valuable results.

Darwin made his first foreign geological examinations at Porto Praya, and his report on the ancient volcanic activity of the island shows how close a student he was. Here he first observed tropical marine forms, and the large brown sea-slug, or Aply- 


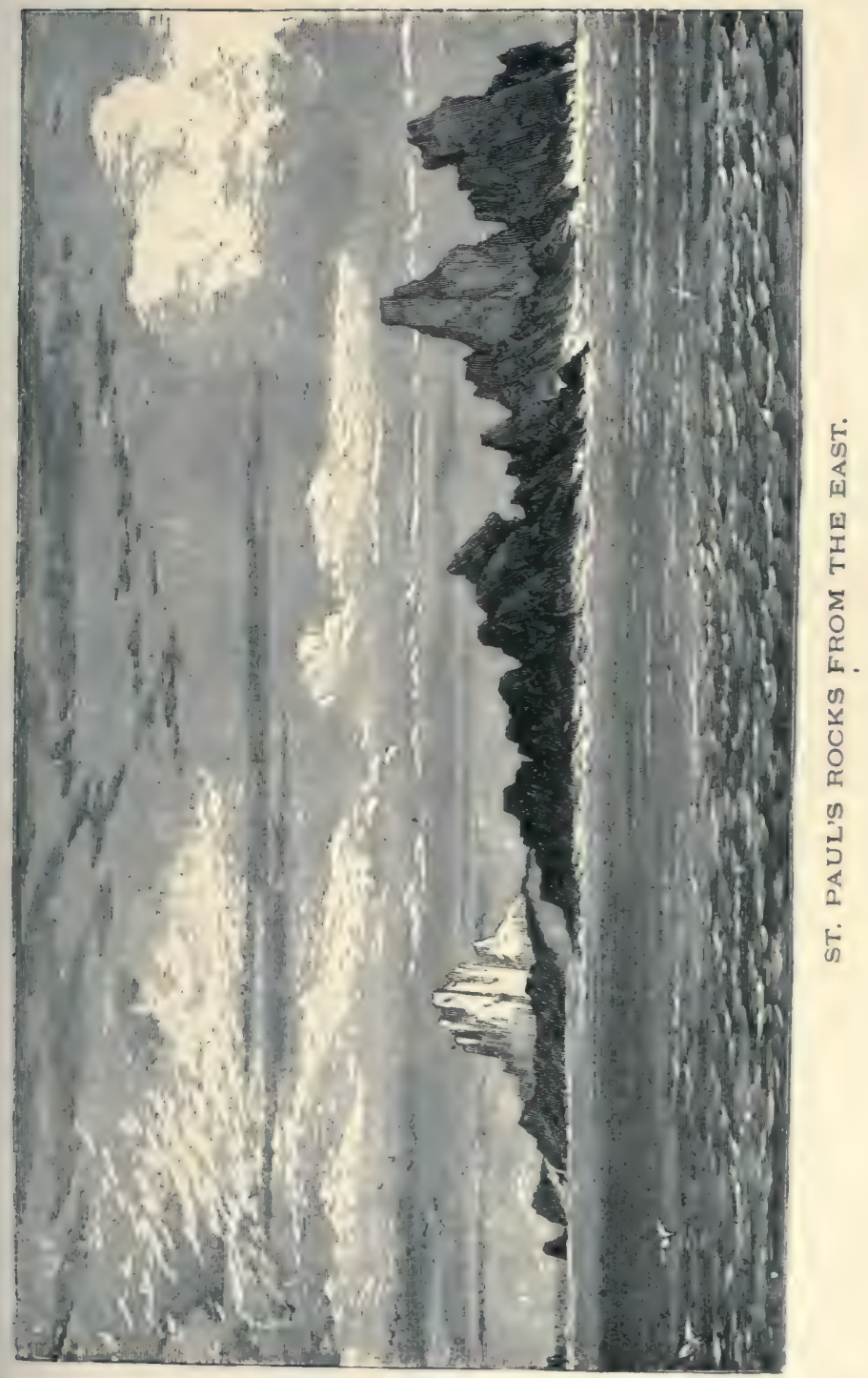



sia particularly, interested him. He found it feeding on the sea-weed, and when disturbed it emitted the peculiar purple fluid for which it is noted. The pools of water left by the outgoing tide formed aquaria of more than ordinary interest. The octopus was the subject of many observations, numbers of which were seen clinging to the rocks by their eight sucker-lined arms, or dashing across the pool, ejecting the cloud of ink which constitutes a part of their defence.

The young naturalist was quick to note their power of mimicry,- - a fact in this and other animals that was dwelt upon in later years by himself and Wallace. He noticed that they changed their tints according to the ground over which they passed, and a close examination showed that clouds of colour were continually passing over them, varying from hyacinth-red to chestnut-brown in tint.

Darwin was probably the first to apply a galvanic battery to these beautiful creatures, with the result that the part touched became almost black. He noticed that they changed colour under all circumstances, whether swimming or resting, and was the first to call attention to the fact that the ink was used as a means of concealing the direction of retreat. One cuttle-fish in this natural aquarium ejected water above the surface from a hole in which it lay concealed, and he suspected that it could direct its aim by turning its tube or siphon in a given direction. Whether this is true or not would be difficult to ascertain, but the author has seen a squid force its stream of ink a foot or more 
above the surface, striking an inquisitive observer full in the face.

Darwin was perhaps the first also to observe that the octopus is luminous at times. One which he kept in his cabin gleamed with a slight phosphorescence, which we can imagine might be used as a decoy, or perhaps to menace its foes.

In February, 1831, the Beagle sighted the famous St. Paul's Rocks, one of the most desolate spots on the globe, consisting of a few rocks five hundred and forty miles from the American coast and three hundred and fifty from Fernando de Noronha. The rocks are somewhat difficult to find, as they rear themselves but fifty feet above the sea and are but little over three-quarters of a mile in circumference. From a distance they appear white, from the constant presence of vast numbers of birds which have made the location their roosting-place for generations.

The birds, principally the noddy and tern, were so tame that any number could have been killed by hand. They laid their eggs on the rocks where the sun hatched the young. Desolate as the spot was, warfare existed; the parent birds provided the young with small fish for food, the flying-fish being considered an especial dainty; but no sooner was it placed by the nest than the young naturalist, who was concealed behind some rock, saw a handsomely mottled crab-the Grapsus-come slowly up, edging along in an innocent, disinterested fashion, then suddenly when within reach seize the fish and dash away. 


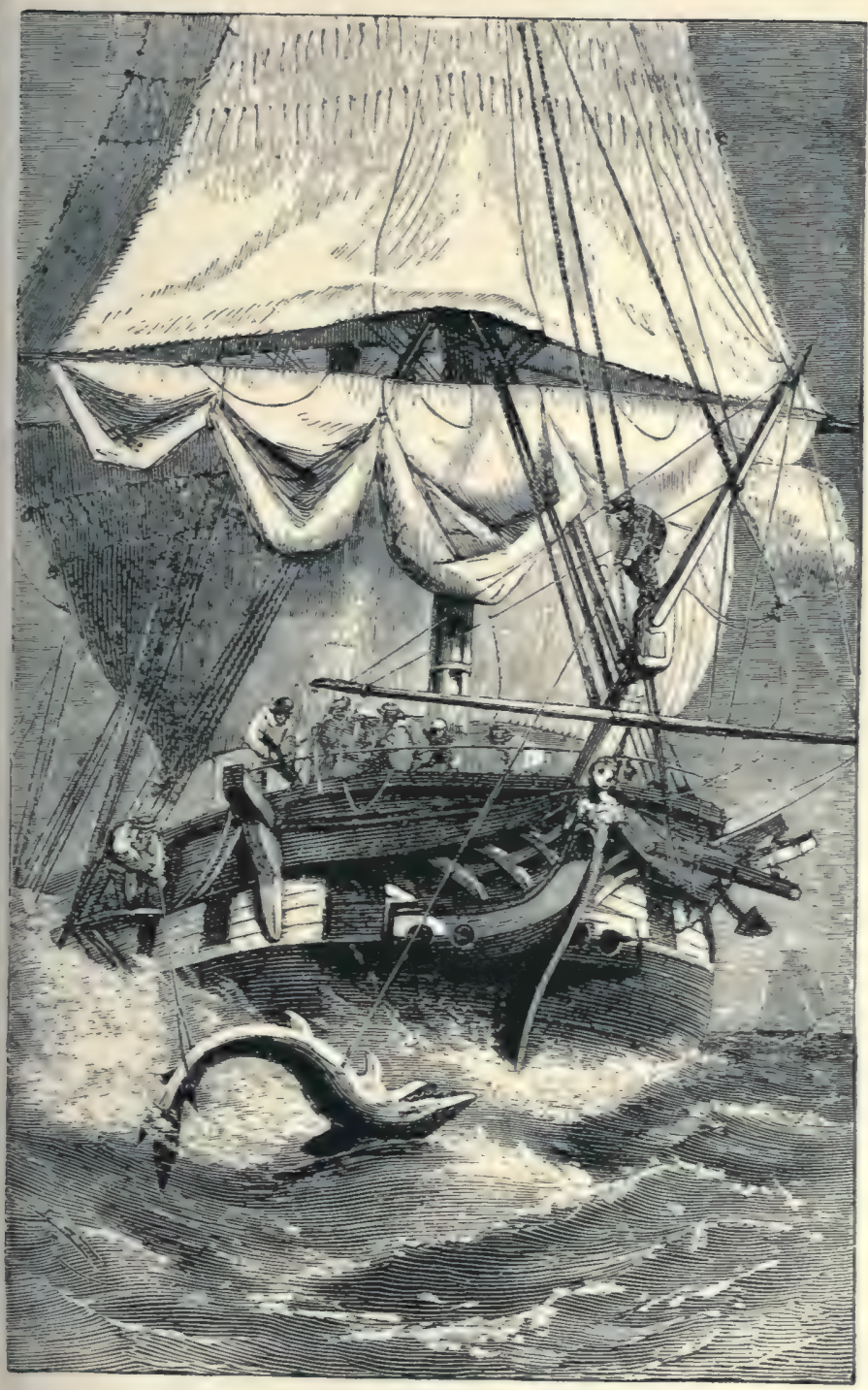

SHARK-FISHING AT ST. PAUL'S ROCKS. 

In this island robber the observer must have found a suggestion for his famous theory of the struggle for existence and the survival of the fittest. The author has watched a similar scene in the Gulf of Mexico, where the Grapsus would attack even the birds. Sir W. Symonds states that he has witnessed the same at St. Paul's, the crab dragging young birds away to devour them.

Darwin found little of interest here from a botanical standpoint, not even a single plant or lichen appearing, though several spiders, flies, moths, and beetles made the barren rock their home. If St. Paul's was deficient in vegetation, it abounded in marine forms of interest, the vast area of submerged rock, with its sea-weed masses, affording ample ground for fishes of infinite variety, while sharks were so plentiful that it was a constant struggle between them and the men. The moment an edible fish was hooked a watchful shark rushed at it, carrying it away before it could be taken in, this occurring so frequently that one man was required to fight these pirates of the sea while another hauled in the fish.

These days were marked by indefatigable energy on the part of the young naturalist. When not investigating or peering among the rocks with hammer or collecting-glass in hand, he was at work in his cabin studying the strange animals he had found, and making notes in his log, as to the colour, habits, and the thousand and one points of interest to the lover of science.

From St. Paul's the Beagle bore away for Fernando de Noronha, a desolate ancient volcanic rock upon 
which Darwin landed with great difficulty, owing to the heavy sea, and found to be completely covered with a dense jungle hard to cross or penetrate. It was in this neighbourhood that the young naturalist underwent the experience of crossing the line. Neptune came aboard, as usual, and claimed as a victim every one who had not crossed the equator. Darwin submitted with his accustomed good-humour; was lathered with soft-soap and tar, then shaved with a saw, and finally dumped unceremoniously into a sail full of water, having as a consolation the reflection that he was but one of many predecessors.

On the last day of February the Beagle made Bahia, where Darwin for the first time found himself in a purely Southern country with a wealth of tropical verdure on every hand. The ocean teemed with animal life, new and striking to his eye, while it was but a step into the tropical forest, where vegetation ran wild and flourished with a rank exuberance that he had never dreamed of. In his Journal he penned the following: "Delight itself, however, is a weak term to express the feelings of a naturalist who, for the first time, has wandered by himself in a Brazilian forest. The elegance of the grasses, the novelty of the parasitical plants, the beauty of the flowers, the glossy green of the foliage, but, above all, the general luxuriance of the vegetation, filled me with admiration. A most paradoxical mixture of sound and silence pervades the shady parts of the wood. The noise from the insects is so loud that they may be heard even in a vessel anchored several hundred yards from the shore; yet within the recesses of the 


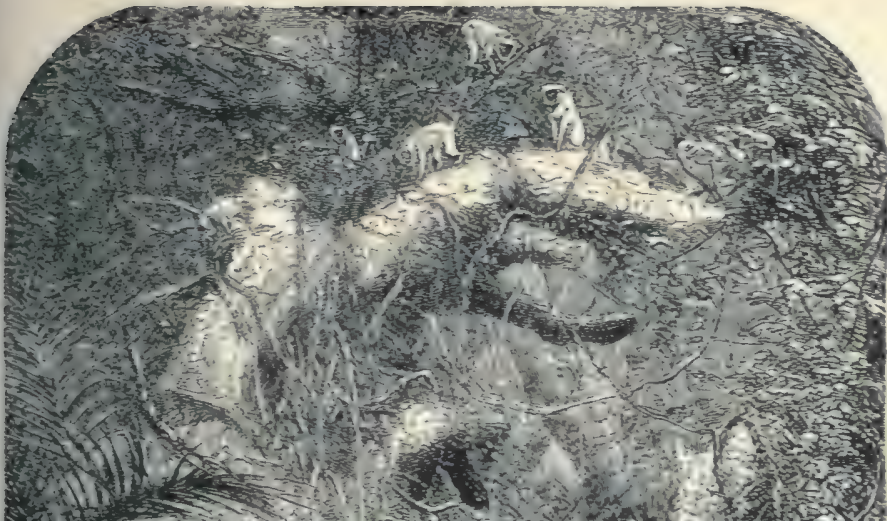

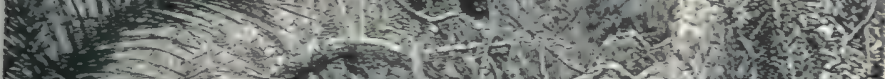

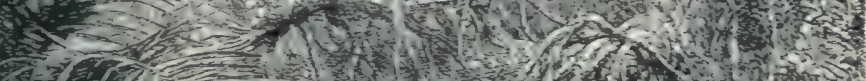

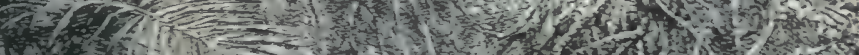

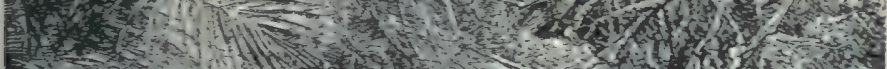

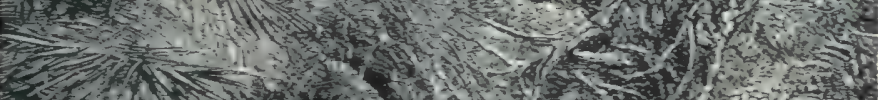

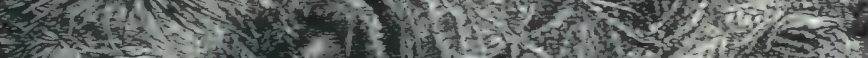

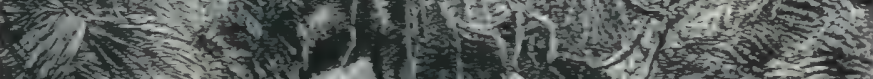

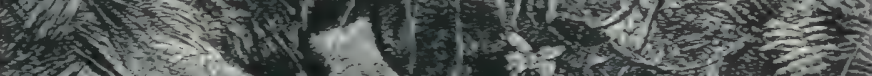

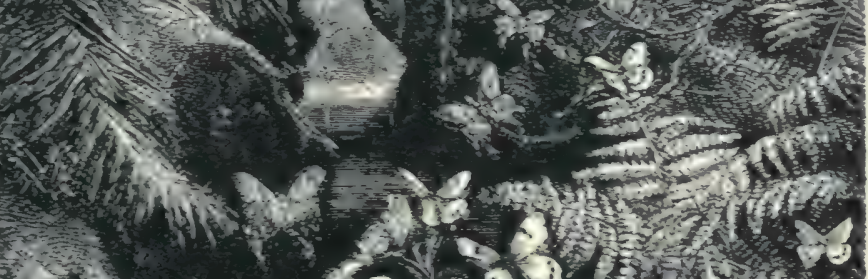

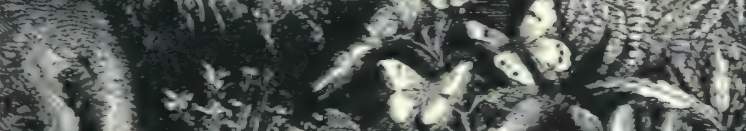

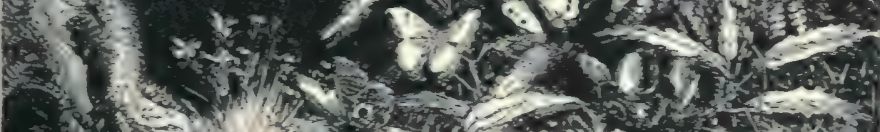
mat nom

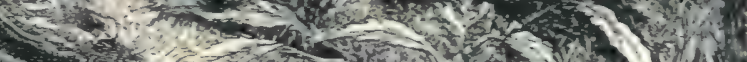

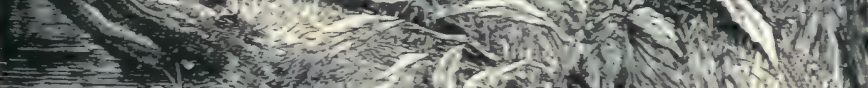
3.5.

A BRAZILIAN COLLECTING-GROUND. 

forest a universal silence appears to reign. To a person fond of natural history, such a day as this brings with it a deeper pleasure than he can ever hope to experience again."

Here Darwin divided his time equally with animate and inanimate forms. We find him to-day at Botofogo Bay among the treasures of undescribed species, not merely novelties, but forms which had never been seen by scientific eyes before. We can imagine his joy as he compared these discoveries at night with the authorities he had at hand, and realised that here was not one but hundreds of creatures actually undescribed. He compares his geological studies here to gambling in their excitement, and his reflections upon the structure of the rocks were farreaching and valuable.

It is difficult to determine which he enjoyed most, geology, botany, or marine zoölogy, but to the last he gave perhaps the most attention. Among the curious fishes he noticed here was the Diodon antennatus, which has a peculiar habit of inflating itself. Placing one in a boat, flabby and flat, it immediately began drawing in air, all the while assuming a more rotund appearance, until finally it rocked to and fro a veritable ball covered with spines, and upon being tossed over floated upon the surface like a balloon. The author has often tried the same experiment with the Diodon of the Gulf of Mexico, it invariably ridding itself of air in a few moments.

Darwin found that the expanding or blowing-up process was produced in two ways. This little fish when inflated could swim feebly, though drawing but 
little water, and would use its tail like a propeller. Its short spines were like those of a hedgehog, and it would hardly be supposed to have enemies, yet our naturalist was told by a Dr. Allan, that sharks would swallow them alive, and that in one instance the Diodon, objecting to this Jonah-like programme, actually ate its way out through the side of the shark, killing it with its sharp, bony, ivory-like teeth. A peculiarity of this fish is that from the lower portion a rich crimson dye exudes which is almost indelible.

For two weeks the Beagle lingered at Bahia, during which time the young naturalist made some remarkable collections, which added materially to the existing knowledge of science, then she bore away to the south.

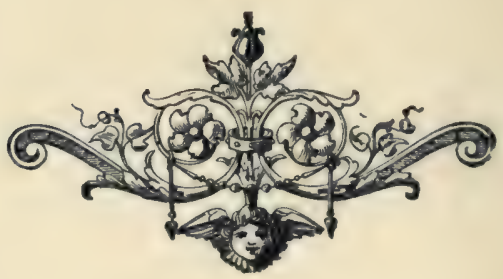




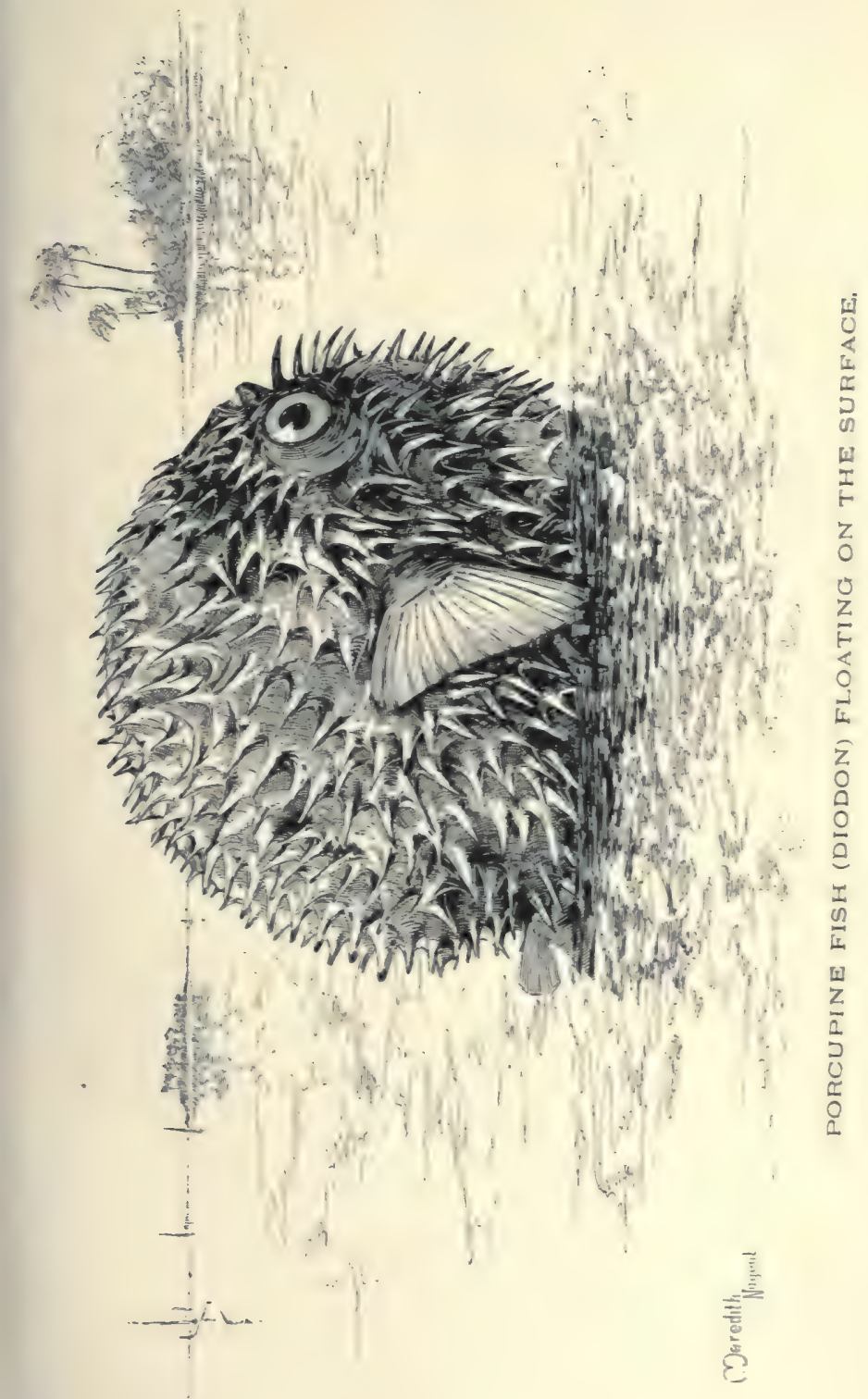





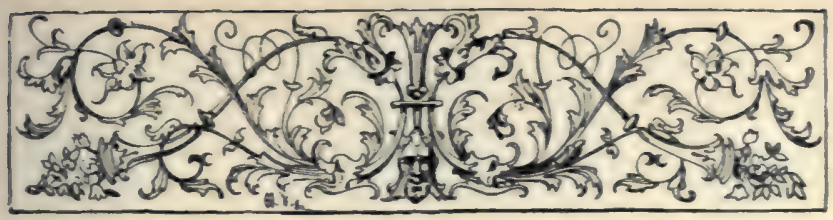

\section{CHAPTER IV.}

\section{IN SOUTHERN SEAS.}

The Log-Book-Bahia-Singular Appearance of the Water-The Vampire Bat-Slavery-Trips into the Country-Rare Collections-In the Brazilian Forest-Shooting Monkeys-The Click of a Butterfly-Jumping Spiders-Electrical DisplaysThe Plata.

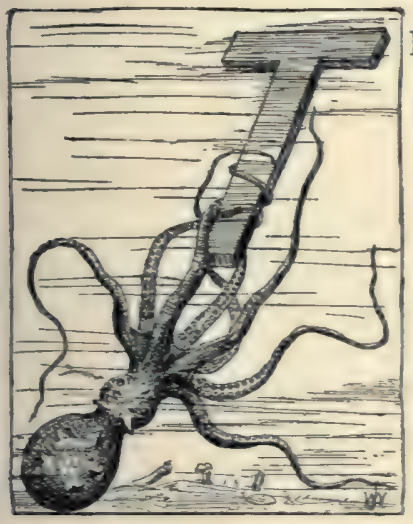

HE sea life of our young hero was a time of continued activity. Every moment when not completely incapacitated by sea-sickness was devoted to his studies, and to the natural history log-book which he was keeping. From the stern of the vessel he swung various kinds of nets to entrap the smaller forms of floating or pelagic animal life, while fishing-lines were employed to capture rare and unknown members of the finny tribe. A few miles from Bahia, Darwin's attention was called to the strange 
appearance of the water through which the Beagle was sailing. From a rich opalescent-blue, it had changed to a reddish-brown, so that the entire ocean seemed to reflect a copper-bronze hue, weird and uncanny in its aspect. Some of the water, upon being placed under the microscope, appeared to contain large masses of chopped hay, which proved to be conferv'e of a reddish tint. Some of the patches covered several miles in extent, entirely changing the tint of the ocean. Darwin comments on the fact as remarkable, that these minute forms could keep together in the lines and bands that extended so many miles over the sea.

The colour of the ocean, from this and similar causes, seems to have engaged his interest at various times. On the coast of Chili he noticed that the water was a dull-red hue, that might have come from some muddy river. This was due, he found, to some minute animal which was, to use his term, continually exploding or throwing out a mass of dark-brown granular matter, probably eggs. $\mathrm{He}$ noticed, in one instance, a patch of these animals that covered several square miles, and comments upon the vast numbers of individuals which must have made up the concourse. Later, at Tierra del Fuego, he found the ocean coloured a deep red by the presence of innumerable crustaceans, while near Galapagos the ship forged through water of a rich yellow, due to another source. These are among the causes which give the names yellow, white, and red to the various seas.

The objective point of the Beagle, after leaving 


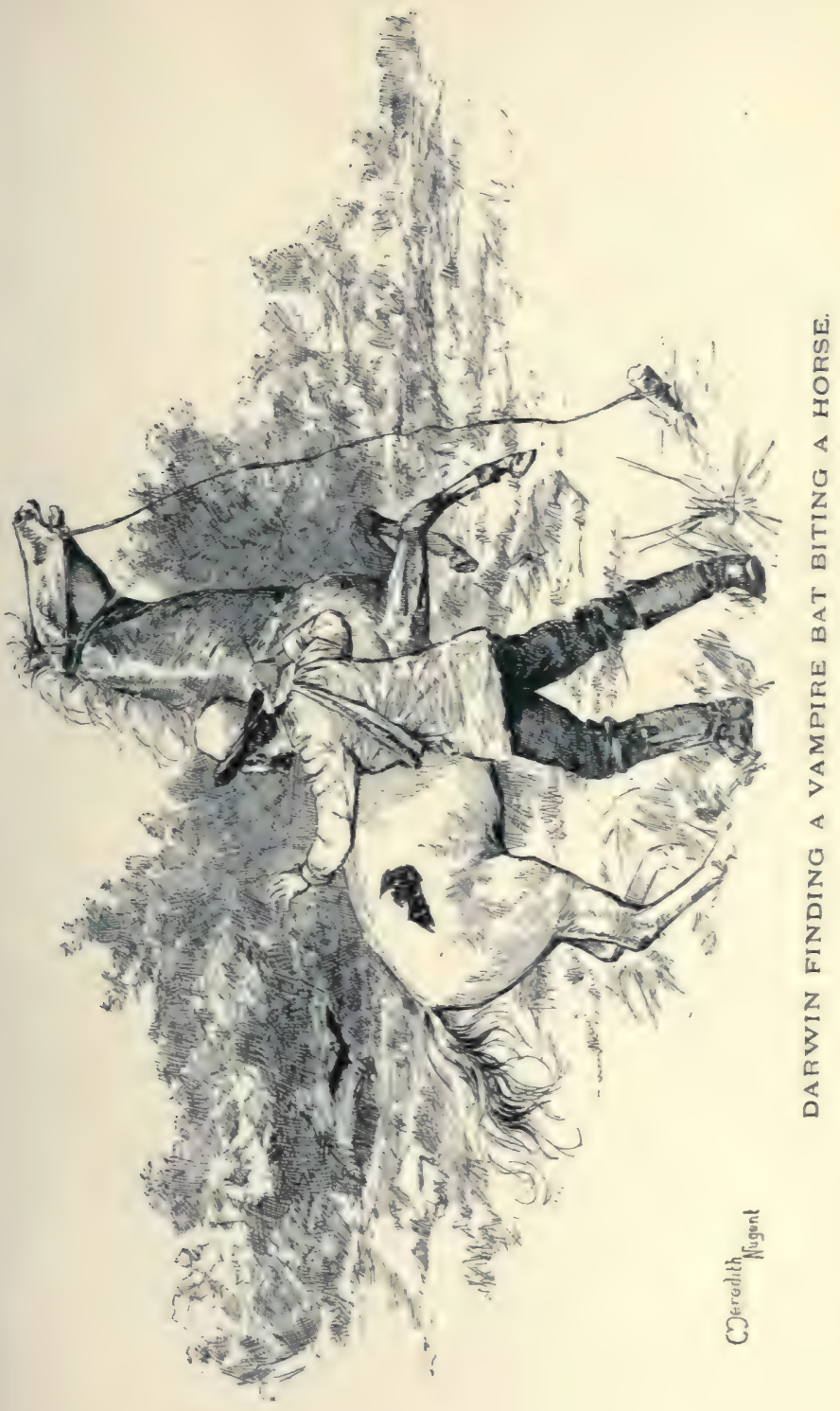



Bahia, was Rio de Janeiro, and while here Darwin went on an extended trip into the interior, going over ground which no naturalist of his attainments had passed before. The country was rich in promise, and, being made up of forest and clearing and abounding in lakes and streams, specimens were everywhere found. The birds engaged his attention, especially the white cranes and egrets, while in the forests he was particularly attracted by the luxuriant vegetation and the wonderful and beautiful flowering parasites.

It was during this trip that Darwin was enabled to give the world definite information regarding the vampire bat. In England and other countries this creature was popularly considered a monster of enormous size that sucked the blood of its victims, often destroying them. While this belief did not prevail among scientific men, the latter doubted that the vampire fed upon blood at all.

The party had arrived at Engenhodo, and the worn and exhausted animals had been tied out, when one of the men noticed a small bat resting upon the withers of one of the horses. Darwin secured it while in the act of sucking blood from the animal, so determining the question. The bat was the one known to science as the vampire or Desmodus d'orbignyi.

Darwin, as might have been expected from one of his nature, had views upon slavery from which no extenuating circumstances could swerve him. He was radically and utterly opposed to it in any form, and his indignation was continually aroused by the 
evidences, which were ever apparent during this trip, of its existence. On a large estate to which he was invited, some trouble occurred which nearly resulted in the sale of all the women and children in the public auction at Rio. He refers to the fact that self-interest, not compassion, was the sole preventive to what he considered the grossest of crimes. Indeed, he says: "I do not believe the inhumanity of separating thirty families who had lived together for many years ever occurred to the owner, yet I pledge myself that in good-feeling and humanity he was the superior to the common run of men. It may be said there exists no limit to the blindness of interest and selfish habit."

So outspoken was our hero upon this subject that it was the cause, later, of an open rupture between himself and his friend Fitz-Roy. Fitz-Roy not only defended slavery, but praised it, which led to so indignant a response from the young man that what may be said to be the entire future of Darwin as a scientist hung in the balance. Fitz-Roy apologised, and requested Darwin to overlook his offensive remarks, and the breach was healed, but our hero never overcame his repugnance for the institution, and would, in America, have been a rigid Abolitionist.

During the trip in the country back of Rio, he made many observations, which may be found in his later works on botanical subjects. $\mathrm{He}$ noted the prodigious growth, the binding together of the forest trees by a maze of lianes, and here he made his first important studies with the sensitive plants, 
noting the strange effects occasioned in the mimosæ, as they drooped their sensitive petioles when disturbed. From the forest he returned to the shores of Botofogo Bay, where he devoted himself to a study of the invertebrate animals which abounded there. The Planarian worms were a constant source of interest, specimens found near here possessing a singular tenacity to life even when the body appeared dead or lifeless, the mouth parts protruding as he touched them with his forceps, showing a high state of irritation and vitality. Darwin discovered twelve species of these interesting creatures, which he fully describes in the "Annals of Natural History." One of his experiments was to cut a planarian in two parts and devote a certain amount of time to an examination of the several members. For nearly a month he watched a marvellous transformation, namely, the formation of two separate individuals out of the single worm.

The forest in which these worms were found abounded in game, and with an old priest and a native Darwin often wandered far from the ocean. Here he first witnessed the skill with which the natives employed the knife to cut vines and creeping plants. So clever had they become that it was used as the American Indians do the tomahawk, the blade being thrown a long distance with unerring skill.

Ring-tailed or prehensile monkeys were common, and two of the bearded variety occasioned them no little trouble to capture. Though shot dead, they still clung to the limbs of a lofty tree, and the latter had to be cut down to obtain them-an arduous and 
laborious operation. The forest afforded constant opportunities for observing the wonders of phosphorescent insects, the brilliant fire-fly (Lampyris occidentalis) illumining the darkest recesses with its light. Darwin's investigations with these insects showed that the light was most intense when they were irritated; where the skin was injured the light was bright, while other portions gave no evidence of phosphorescence. Decapitating one he found that the light was still uninterrupted though not as brilliant, and in a specimen which he killed the strange light gleamed for an entire day.

He collected the various forms of these insects, the larvæ and adults, and made a series of experiments that have ever been of value to those who have made them a study. The larvæ he kept alive by feeding them upon raw meat, and while watching them, he learned that they used their tails as suckingorgans, and that the latter contained saliva glands which were employed in a singular manner. Thus when the larva felt the pangs of hunger, it reached its tail over and deposited upon its mouth, or the food it was preparing to eat, a drop of saliva.

The elater, or Pyrophorus luminosus, was the most conspicuous luminous insect here, abounding in vast numbers and dashing through the gloomy recesses of the forest, often followed by an apparent blaze of light.

Darwin discovered during this expedition the true explanation of the leaping powers of the elater, finding that it was due to the elasticity of the spine, which threw the insect whirling into the air like a veritable spring. 


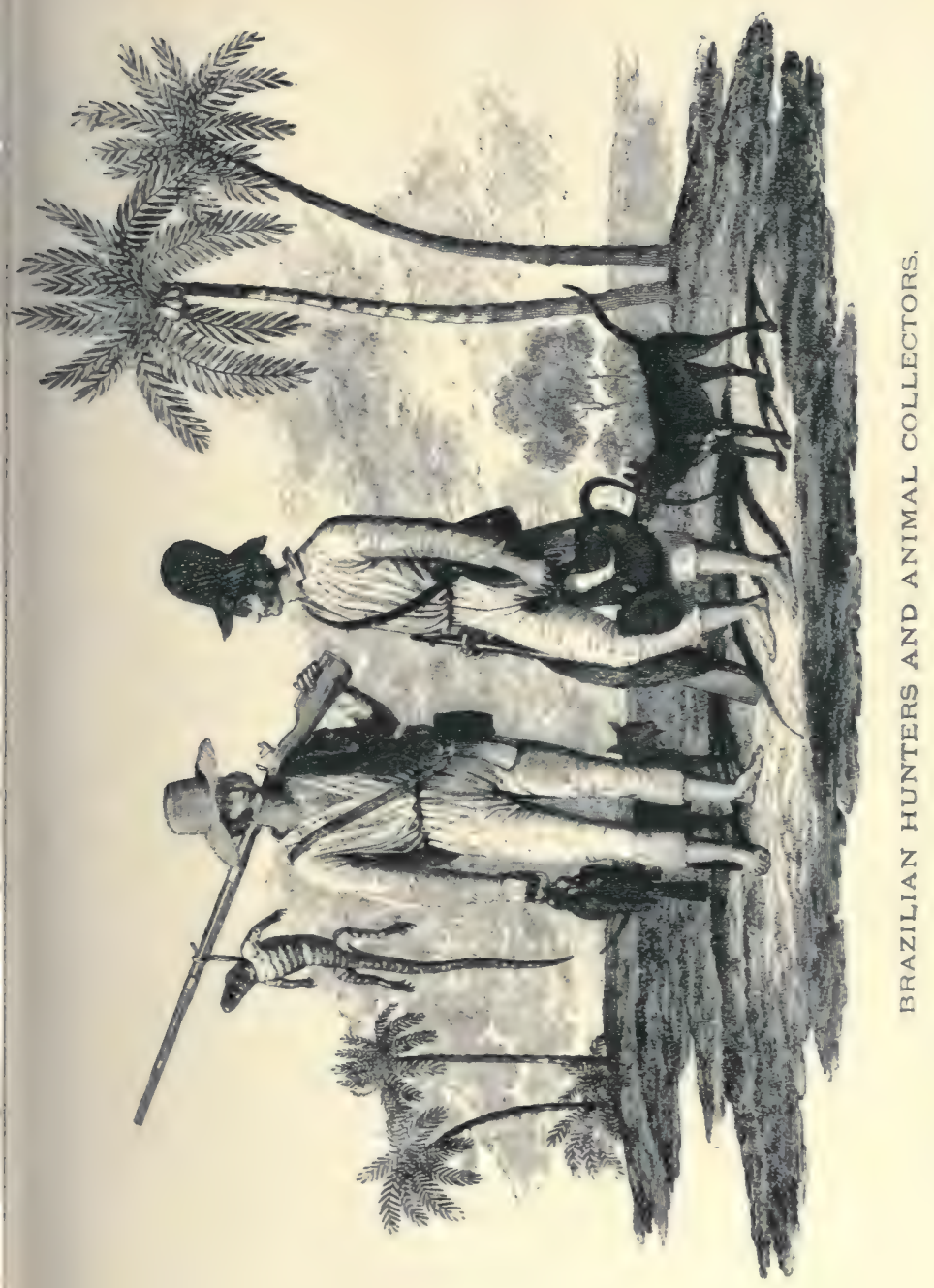



That these woods and their immediate surroundings impressed our young hero deeply, we can readily see, as he frequently refers to the beauties and wealth of the tropical foliage, and in one instance he compares the effect to the "gayest scenery of the operahouse or the great theatres."

While in Brazil, Darwin formed the finest collection of insects ever made in this country, and remembering his youthful fondness for beetle collecting, his pleasure and enthusiasm can be appreciated. In his notes on this work, we see evidences of the theories that he formulated in laterlife. He was impressed with the fact that the large butterflies seemed highly coloured to conform with the gorgeous foliage and flowers of their home.

The beautiful Papilio feronia attracted his especial attention, and he made a careful study of its peculiarities, which might well be an example to young naturalists. He noticed that it invariably alighted with its head downward, with wings extended in a horizontal plane, instead of being folded vertically. When it moved, instead of edging off it ran, using its legs nimbly for the purpose, surprising the young naturalist with its agility.

While watching this interesting creature, Darwin discovered that it made a noise, and thus was the first to listen, if not to the voice of the butterfly, to a sound that is used for a similar purpose. He noticed the noise when two butterflies were chasing each other, a slight resonant clicking coming to his ear, distinctly audible twenty yards away. He describes it as resembling a "toothed wheel passing 
under a spring catch." Later, when examined, the butterfly was found to possess a drum, the organ being found, according to Mr. Doubleday, at the base of the fore wings, between the costal nervure and the sub-costal. With the beetles Darwin was disappointed: there were not so many large and attractive forms as he had expected, though small ones existed in vast numbers, and we find him expressing surprise at the absence of carnivorous beetles when the hot tropical country is the home of the carnivora or flesh-eaters among larger animals. Bees and wasps were so abundant that the thought was suggested that perhaps they supplied the place of carnivorous insects.

Many hours were spent in watching the ant armies traversing the wood, and experimenting to test their intelligence and bravery. The habits of the wasp were a constant source of pleasure to him. In the corner of a veranda a certain species had made celllike homes of clay; these they stuffed full of insects of various kinds, which had been paralysed by the sting of the wasp, and while helpless the eggs of the latter were deposited in them, where they ultimately hatched out, the grub obtaining its food from the comatose victim.

The habits of the larger wasps were also closely studied, and the bull-dog-or bloodhound-like tenacity of the creatures, now so familiar, observed carefully for the first time.

Darwin noticed that the number of spiders here was greater, in proportion to other insects, than in England. The jumping spiders particularly inter- 


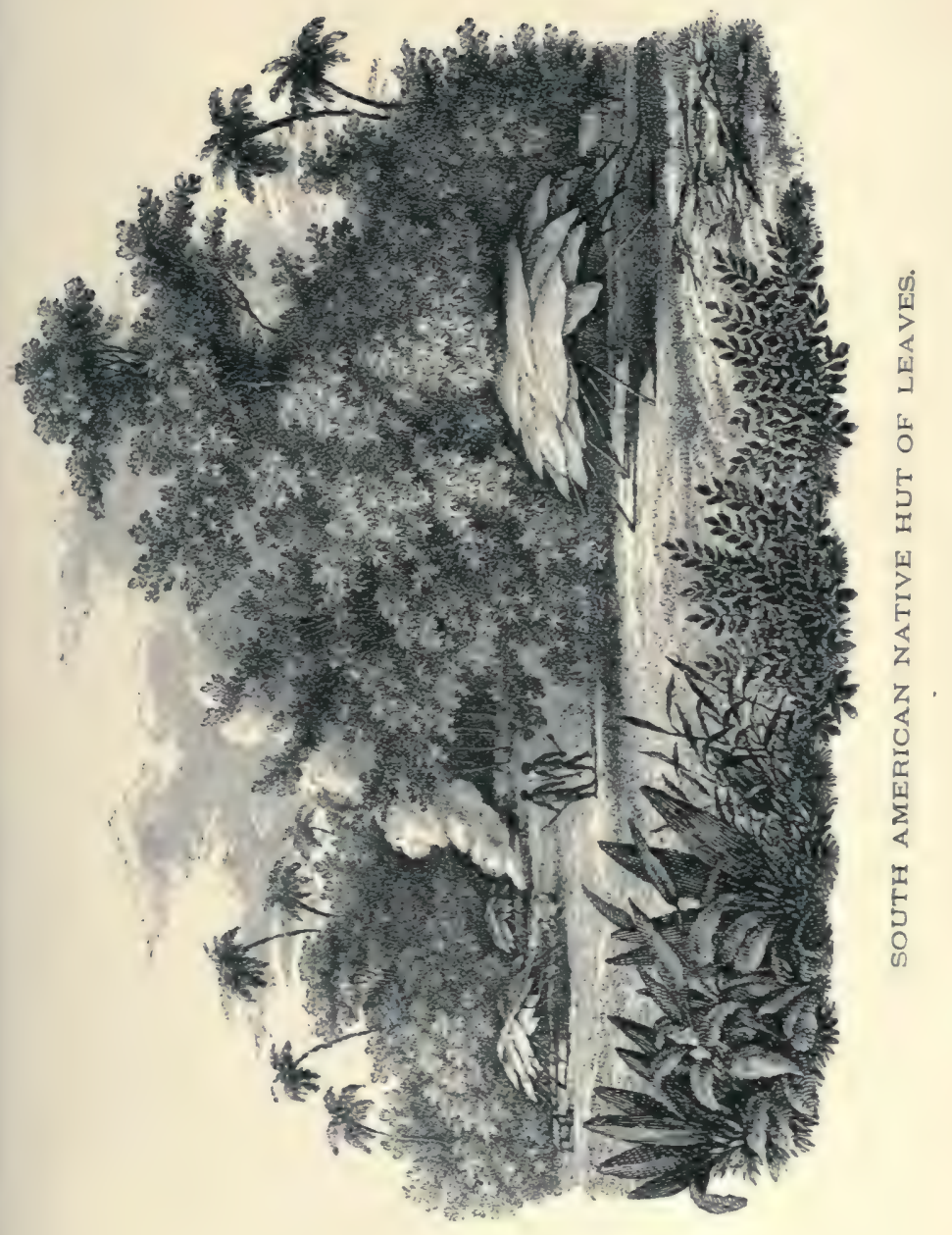



ested him; their leaps upon their prey reminding him of the tiger in pursuit of its victim. Over every pathway in the forest he found a strong elastic yellow web of a spider, allied to the Epeira clavipes, and note how carefully he examined them! In every web was found a small parasitic form, which lived here undisturbed by its giant ally, feeding upon the minute insects entrapped,- - the crumbs from the big spider's table. The young naturalist here observed a remarkable instance of defence on the part of a spider. As he approached, the little insect imparted to its web a swinging movement, which increased so rapidly that in a few moments the cunning insect was invisible, or nearly so, from the rapidity of its motions. This spider had a most skilful method of disposing of its victims. The moment a wasp or fly became entangled, the Epeira held it at arm's length, and, in some miraculous way, whirled it over and over, winding it up in a broad band of threads, taken from its spinners, so that in a few moments the captive appeared to be encased in a cocoon, and then helpless was killed by the deadly jaws of the monster.

To show the virulence of the poison, Darwin found that half a minute was sufficient to kill a large wasp.

On July 5, 1832, the Beagle left Rio, sailing for the Plata. In the mouth of the latter he studied the porpoise, watching its movements across the bow as the vessel rushed along at full speed. Seals and penguins were present in great numbers, and were so demonstrative at night that the officer of 
the deck thought the noises proceeded from the shore.

The Plata is somewhat noted for its electrical displays, and the young naturalist was witness to some remarkable phenomena. The tip of the masts and ends of the booms became illuminated with balls of fire, while the vane upon the topmast looked as though it had been rubbed with phosphorus. The ocean itself seemed to vie with the atmosphere here in its phosphorescent displays, and gleamed with lights so brilliant that Darwin could trace everywhere the movements of seals and penguins, and even distinguish the forms as they were outlined by the mysterious phosphorescent light. Accompanying these displays was an electrical storm, which caused vivid flashes of lightning to play about the ship.

The Beagle had now reached the first point of her projected work, which was to survey the coast of South America from the Plata south, an undertaking which it was estimated would take two years to accomplish.

Darwin went ashore, and made his headquarters at Maldonado,--a rich collecting district from a zoölogical standpoint. Collecting had its drawbacks here, as, a few days previous, a man had been found murdered, hard by a cross which formed the record of a similar crime. A guard, then, seemed necessary, and perhaps no naturalist ever went forth after bugs, birds, and reptiles with so singular an escort. To see the cavalcade approaching, one might well have supposed that men, not simple specimens, were the object. The troop consisted of a dozen or more 


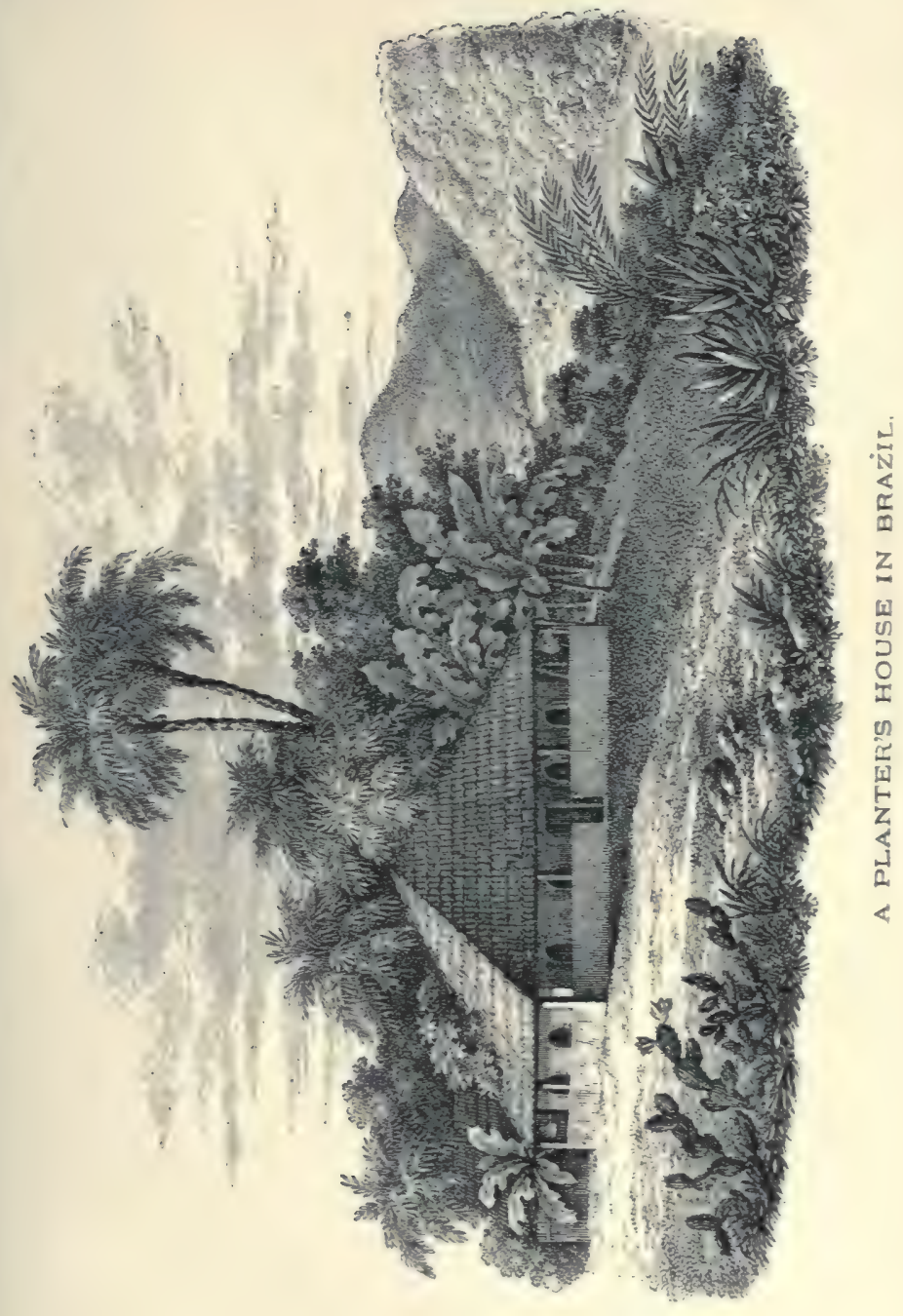



horses, the men in charge being armed with long sabres and pistols. The equipment was unusual but effective, as a fine and representative collection of the fauna of the locality was made by the indefatigable naturalist.

The human inhabitants of this region possessed an interest to our hero, due to their extreme ignorance. They looked upon him as a necromancer, and his fame spread far and near. The rich who could not visit him sent for him, and begged that he would exhibit the compass by which he made his way over their country. They could not understand it, and their ignorance was a continual surprise to the visitor. He found that they did not know the shape of the earth, or anything of geography, while the matches which he carried and ignited by biting excited the liveliest curiosity. Upon one occasion an entire family, with a number of friends, gathered to witness this performance, which Darwin goodnaturedly repeated. Indeed he was a mystery to the entire people. Why he washed his face in the morning, allowed his beard to grow aboard ship and removed it when ashore, his handling snakes, and apparent knowledge of those which were venomous, were all features that caused him to be looked upon with suspicion and wonder.

At Maldonado Darwin first met the Gauchos, the men who correspond to the cowboys of America, -a wild, daring race that, with their enormous clanking spurs, sharp daggers, and picturesque costumes, presented a striking spectacle as they dashed away upon their wild horses. It was here that the 
naturalist first encountered the rhea, the great bird that is the ostrich of South America. They were so tame that he approached within a few yards of a flock, when they turned, spread their great wings, and sped along like the wind. Putting his horse to its greatest speed to keep up with them, Darwin enjoyed the novelty of a race with thirty or more of the huge birds, but even then they left him far behind, with an ease that was surprising.

The Gauchos employed a weapon that so aroused the particular attention of our hero that he endeavoured to learn its use, finally succeeding after a varied experience. The weapon was called the bolas, and consisted of two or three balls of stone bound in leather and connected to a common centre by thongs of the same. In using it the natives held one ball in the hand and whirled the others about in a rotary motion, then let go, the victim being completely wound up in the tangle that ensued and falling helpless to the ground. The bolas is of different sizes and material, according to the game, large balls being used for the ostrich and small ones for lesser forms.

Darwin soon became an expert thrower of the bolas on foot, but one day, in essaying a throw on horseback, by some accident he hurled one of the balls about the leg of his own horse, which jerked the other balls from his hand, which went whirling about his charger, who stood for a moment completely wound up. The Gauchos found much amusement in this, and laughed heartily at his discomfiture, having never before seen a bolas thrower catch himself. 


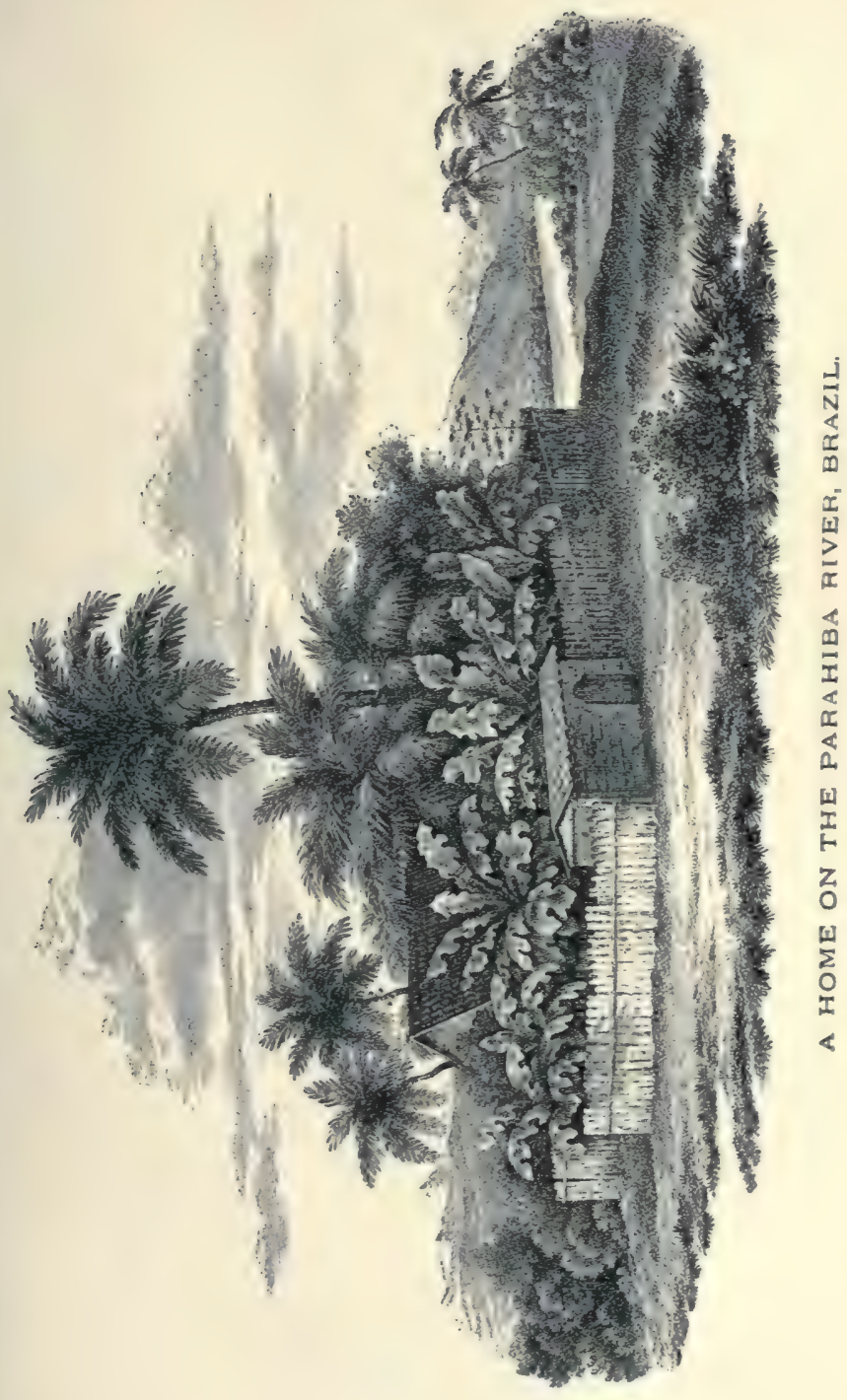



Among the birds of this locality the South American quail (Nothura major) attracted his notice by its numbers. He found that the natives were in the habit of catching them by walking around them in a circle, gradually drawing nearer and nearer, the birds becoming confused and huddling together, until finally they could be knocked over with the hand.

Another method was employed by the children, and consisted in walking around them on a slow horse and throwing a small lasso over them. In this simple manner, says Darwin, a child would take thirty or forty birds a day.

Darwin's studies at Maldonado were carefully made, and as a result he had a large collection representing the fauna of the place. He took eighty species of birds here, nine species of snakes, and many of the large mammals. In hunting the deer he found that it was easily approached on foot, but fled like the wind before a horse. This was due to the fact that every one rode here, and the animals did not recognise an enemy in the unmounted hunter. Darwin took advantage of this, and assuming strange positions so aroused the curiosity of the deer that he could pick them off with ease.

His collection included eight kinds of gnawers, but, best of all, the king of the tribe, the great capybara or Hydrochorus. This singular animal he found in the Maldonado streams in large numbers, which offered him ample opportunities to observe its ways and habits. One, which he shot at Monte Video, weighed nearly one hundred pounds. They were extremely tame, allowing him to approach within 
several yards, when they would run into the water and dive, coming up to utter their singular bark. Their tameness he ascribed to the fact that the jaguar had almost disappeared from that locality, and the Gauchos rarely hunted them.

In the woods of Maldonado Darwin often heard curious noises, arising apparently from the ground, and resembling a bark or grunt. Investigation resulted in finding a curious little subterranean and nocturnal animal, the Tucutuco. Many of them were blind or partly so, and we find the naturalist speculating on the subject. "Lamarck," he says, "would have been delighted with this fact had he known it, when speculating (probably with more truth than usual with him) on the gradually acquired blindness of the Aspalax, a gnawer living underground, and of the proteus, a reptile living in dark caverns filled with water; in both of which animals the eye is in an almost rudimentary state, and is covered by a tendinous membrane and skin. In the common mole the eye is extraordinarily small, but perfect, though many anatomists doubt whether it is connected with the true optic nerve; its vision must certainly be imperfect, though probably useful to the animal when it leaves its burrow. In the Tucutuco, which I believe never comes to the surface of the ground, the eye is rather larger, but often rendered blind and useless, though without apparently causing any inconvenience to the animal; no doubt Lamarck would have said that the tucutuco is now passing into the state of the Aspalax and Proteus."

We observe here that the young naturalist had 


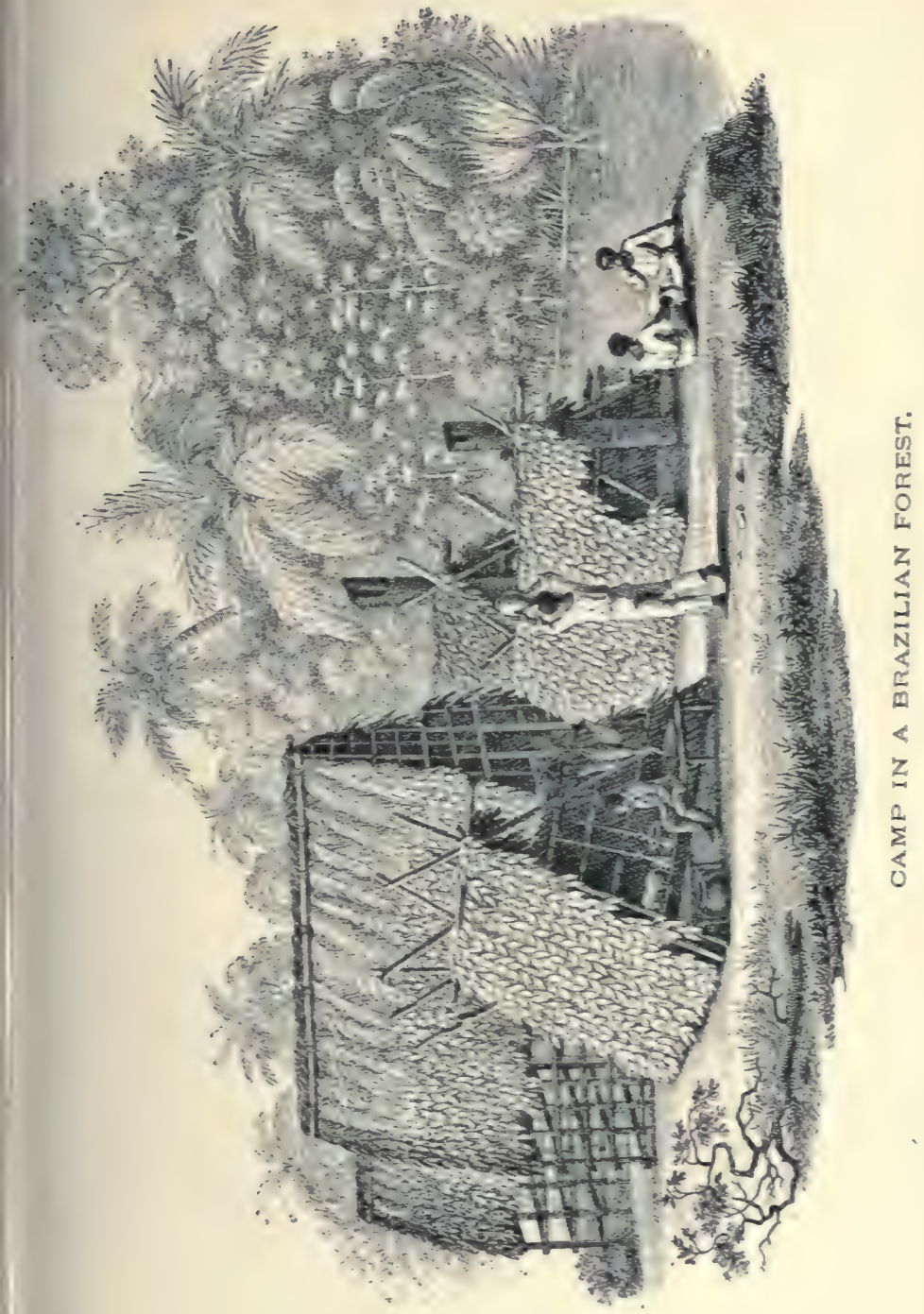



already begun to think seriously of the great problems to which he devoted his life in later years.

Among the birds at Maldonado Darwin noticed one resembling a starling, which had a peculiar habit of sitting upon the backs of horses or cattle and pluming its feathers. It was interesting to him for another reason: Azara had ascribed to it the cuckoolike habit of depositing its eggs in the nests of other birds. Darwin found that the same was true of the South American ostrich, which laid its eggs in the nests of others indiscriminately.

Of all the singular birds seen here the Polyborus chamango was perhaps the most interesting. It was a carrion feeder, and Darwin often saw several within the ribs of the skeleton of a horse. They were extremely savage, pouncing upon dogs, seizing rabbits as they came from their holes, and even tearing the leather from the rigging of the ship in what appeared mere destructiveness. One was seen to carry off a heavy bolas, while another seized a large glazed hat belonging to a sailor and bore it nearly a mile from the ship; a small compass in a red morocco case shared the same fate, and was not recovered.

As we have seen, Darwin found the mouth of the Plata famous for its electrical disturbances, and in the sand-banks here he discovered some curious evidences of the frequency of the bolts. Protruding from the sand heaps were numerous vitrified and siliceous tubes formed as the lightning entered the loose sand. The sand was continually being blown about by the wind, thus exposing the tubes; similar ones in other places have been traced for thirty feet. 
Darwin found that the internal surface was smooth and completely vitrified. The walls of the tube were about the twentieth of an inch in thickness. The most remarkable feature about this was the number of tubes in so restricted an area. The entire region bore a bad name. In a single electrical storm thirty-seven places were struck in the city of Buenos Ayres and nineteen persons killed.

In referring to this Darwin says: "I am inclined to suspect that thunder-storms are very common near the mouths of great rivers. Is it not possible that the mixture of large bodies of fresh and salt water may disturb the electrical equilibrium? Even during our occasional visits to this part of South America, we heard of a ship, two churches, and a house having been struck. Both the church and the house I saw shortly afterwards: the house belonged to Mr. Hood, the consul-general at Monte Video. Some of the effects were curious: the paper, for nearly a foot on each side of the line where the bellwires had run, was blackened. The metal had been fused, and although the room was about fifteen feet high, the globules, dropping on the chairs and furniture, had drilled in them a chain of minute holes. A part of the wall was shattered as if by gunpowder, and the fragments had been blown off with force sufficient to dent the wall on the opposite side of the room. The frame of a looking-glass was blackened, and the gilding must have been volatilised, for a smelling-bottle, which stood on the chimney-piece, was coated with bright metallic particles, which adhered as firmly as if they had been enamelled." 


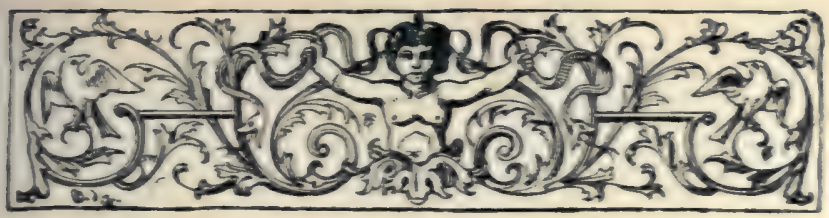

\section{CHAPTER V.}

\section{IN THE LAND OF THE SACRED TREE.}

The Rio Negro-Trips into the Interior-The Sacred Tree-Superstition of Natives-Salt Lakes-Bahia Blanca-A Tomb of Giants-The Mylodon Darwinil-The Armadillo-Hibernation -Careful Work-War-General Rosas-Brutal Natives-Skilled Equestrians.

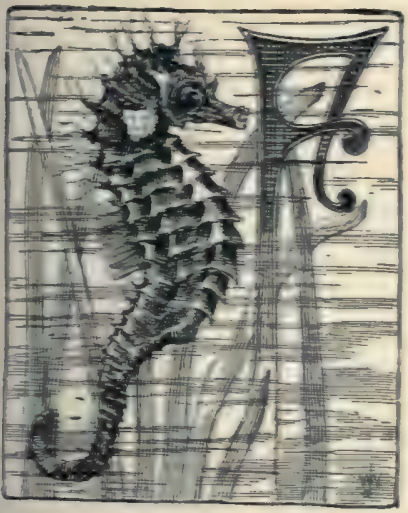

ROM Maldonado the Beagle sailed south, arriving at the mouth of the Rio Negro in August, 1833 . Here Darwin found a newer and more interesting field for work, and applied himself assiduously to the investigation of the local fauna and flora. Nothing escaped his watchful eye, and he not only collected but made careful observations regarding the habits of the various animals, all of which were recorded in the growing log-book, which was to prove such a treasure-house of zoölogical facts in the future. 
He made his headquarters for his land expeditions at El Carmen, about eighteen miles up the river, a town built on the face of a high cliff, some of the houses or homes of the natives being excavated in its face. One of the first objects of interest to attract his attention was a famous salt lake. During the rainy season it was a basin of the strongest brine, but when the dry time came, and the hot summer sun poured down, the water evaporated, leaving a pure white patch of gleaming salt, in remarkable contrast to the surrounding verdure.

This lake was found to be two miles in length, with a layer of salt ranging in thickness from several inches at the border to as many feet in the centre. The interest of the explorer naturally centred in the life of the lake, and he was repaid by the discovery of a worm that existed in sufficient quantities to attract flamingoes here to feed. "Well may we affirm," writes Darwin in his log-book, "that every part of the world is habitable! Whether lakes of brine, or those subterranean ones hidden beneath volcanic mountains-warm mineral springs - the wide expanse and depths of the ocean-the upper regions of the atmosphere, and even the surface of perpetual snow-all support organic beings."

During a trip to the Colorado River with a band of Gauchos Darwin came upon the sacred tree, about which so much has been said and written, it having been described as taking up foreign objects upon its branches. The tree is a low thorny variety, not common, yet conspicuous on the plains by its peculiar appearance. As the party approached, the tree was 
seen to be leafless, the branches being covered by hundreds of objects, the offerings of the Indians, who reverenced it as the altar of Walleechu, such as cigars, pieces of cloth, bits of meat, strings, fruit, and a variety of singular articles. Around the tree was a circle of bones, the sacrifices of horses, which the Indians had made. The Gauchos, though ignorant, as we have seen, looked with contempt upon the tree, and said that they had often witnessed the ceremonies of the Indians, waiting until the latter had disappeared, to help themselves to such articles as possessed any value.

The young naturalist here first encountered the agouti, and he notes it as a singular fact that, while in 1670 the animal was found much farther to the south, it now occupied a restricted area.

From Bahia Blanca, which was reached in the latter part of August, Darwin travelled overland to Buenos Ayres. The former was one of the most interesting localities he had visited, as here he discovered a veritable tomb of the lost races of a former age. Upon the beach, within an area of two hundred yards, he took out, after no little labour, the remains of nine large quadrupeds. They included the megatherium - a sloth-like animal, the megalonyxan allied form, the scelidotherium - an animal as large as a rhinoceros, with a head, according to Professor Owen, who described the remains, resembling that of the Cape ant-eater, or the armadillos. Besides these, he found another giant, which when described was named after him, Mylodon Darwinii; also a gigantic armadillo, with a colossal armour, separated 
into rings; and finally a toxodon-a creature as large as an elephant, but related to the rats and mice and other gnawers.

These gigantic remains aroused the greatest enthusiasm in the young naturalist, and he had the satisfaction of being the first to present to English scientists specimens from this locality. He pictured the appearance of the huge animals when alive, and with Professor Owen later gave graphic descriptions of them. He says: "The great size of the bones of the megatheroid animals, including the megatherium, megalonyx, scelidotherium, and mylodon, is truly wonderful. The habits of life of these animals were a complete puzzle to naturalists, until Professor Owen lately solved the problem with remarkable ingenuity. The teeth indicate, by their simple structure, that these megatheroid animals lived on vegetable food, and probably on the leaves and small twigs of trees; their ponderous forms, and great, strong, curved claws seem so little adapted for locomotion, that some eminent naturalists have actually believed that, like the sloths, to which they are intimately related, they subsisted by climbing back downwards on trees, and feeding on the leaves. It was a bold, not to say preposterous, idea to conceive even antediluvian trees with branches strong enough to bear animals as large as elephants. Professor Owen, with far more probability, believes that, instead of climbing on the trees, they pulled the branches down to them, and tore up the smaller ones by the roots, and so fed on the leaves. The colossal breadth and weight of their hinder quarters, 


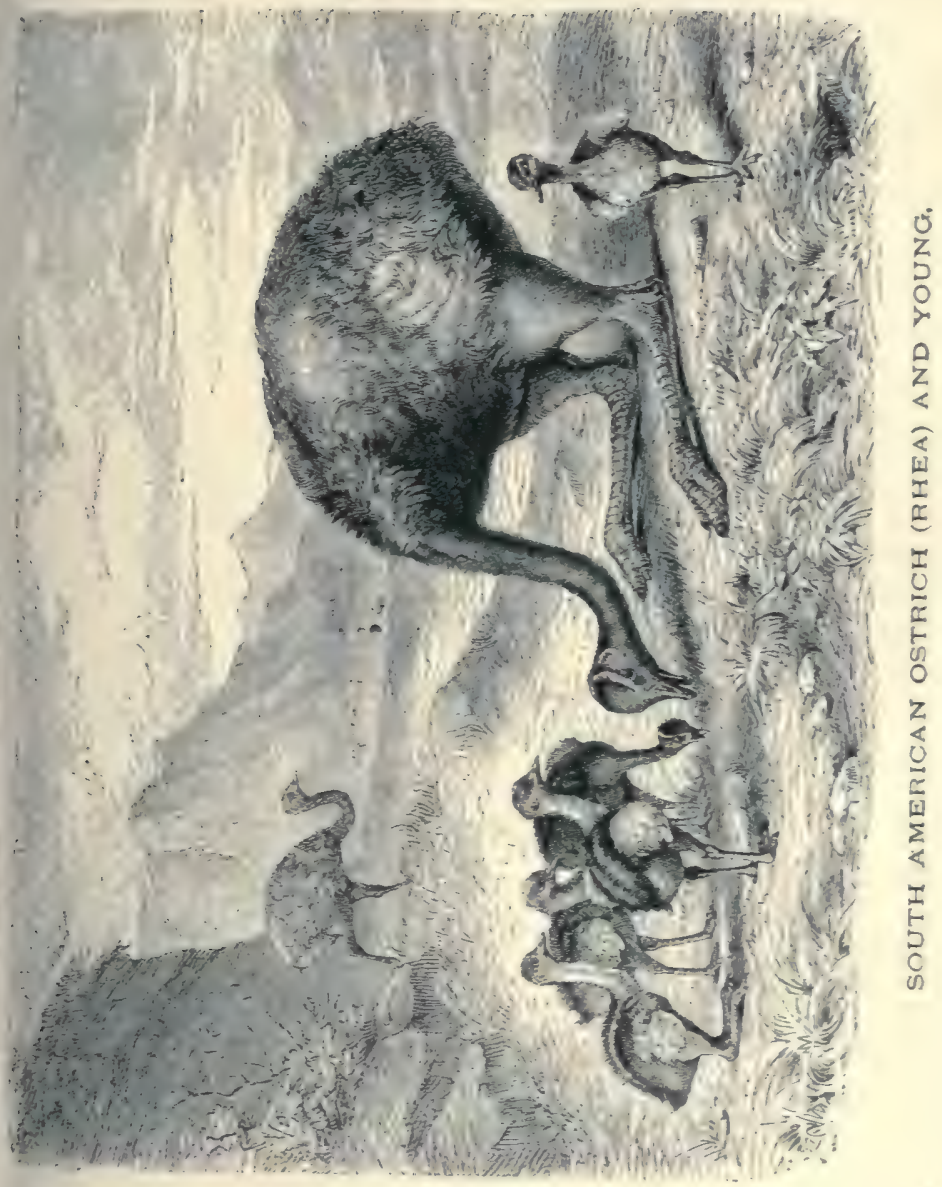



which can hardly be imagined without having been seen, become, on this view, of obvious service, instead of being an incumbrance; their apparent clumsiness disappears. With their great tails and their huge heels firmly fixed like a tripod on the ground, they could freely exert the full force of their most powerful arms and great claws. Strongly rooted, indeed, must that tree have been which could have resisted such force! The mylodon, however, was furnished with a long extensile tongue like that of the giraffe, which, by one of those beautiful provisions of nature, thus reaches, with the aid of its long neck, its leafy food. I may remark, that in Abyssinia the elephant, according to Bruce, when it cannot reach with its proboscis the branches, deeply scores with its tusks the trunk of the tree, up and down and all around, till it is sufficiently weakened to be broken down."

Darwin was particularly interested in the rhea or South American ostrich, and was the first to give a careful account of its habits. As we have seen in a previous chapter, he followed it on horseback, racing with the huge bird in sport, watching it at once with the eye of a naturalist and sportsman. The rhea he found, though living upon grasses and tender roots, by no means confined itself to this diet, as one day while lying in concealment at Bahia Blanca he saw a number come down to the mud flats and feed there, obtaining, according to the Gauchos, small fish; and that they take to the water readily he was convinced on a later occasion by observing several swim the Santa Cruz River, which was at least four hundred yards wide, with a rapid current. In swimming, 
the body of the bird was almost entirely concealed from view, the head and neck alone appearing above the surface, presenting a most comical appearance as they moved slowly along. The cock rhea is the larger, darker coloured, and can be distinguished by the natives from the female at a long distance. While standing in the brush one day the young naturalist heard a deep-toned hissing sound, which he at first thought proceeded from some large wild beast, but soon discovered that it was the cry of the cock ostrich.

Darwin found bird-nesting for ostrich eggs an easy task, the nests being very plentiful everywhere at Bahia Blanca in the months of September and October. Four nests were found to contain twentytwo eggs, while another bore twenty-seven. The egg-hunting was followed on horseback, and one day Darwin almost ran over a cock sitting on a nest. The Gauchos informed him that at times the males were exceedingly fierce, attacking all intruders, leaping at them much after the fashion of an African ostrich.

While observing the ostrich the Gauchos told our hero of another kind which they called the Avestruz Petise, which they said was smaller and more easily captured. But one of these was taken, and not until it had been skinned and cut up for the table did the young naturalist learn that it was the unknown species. The principal parts were preserved, and from these Mr. Gould described the new species, naming it after Darwin, Struthio Darwinii. The specimen is now in the museum of the Zoölogical Society. The rhea proper, according to Darwin, 


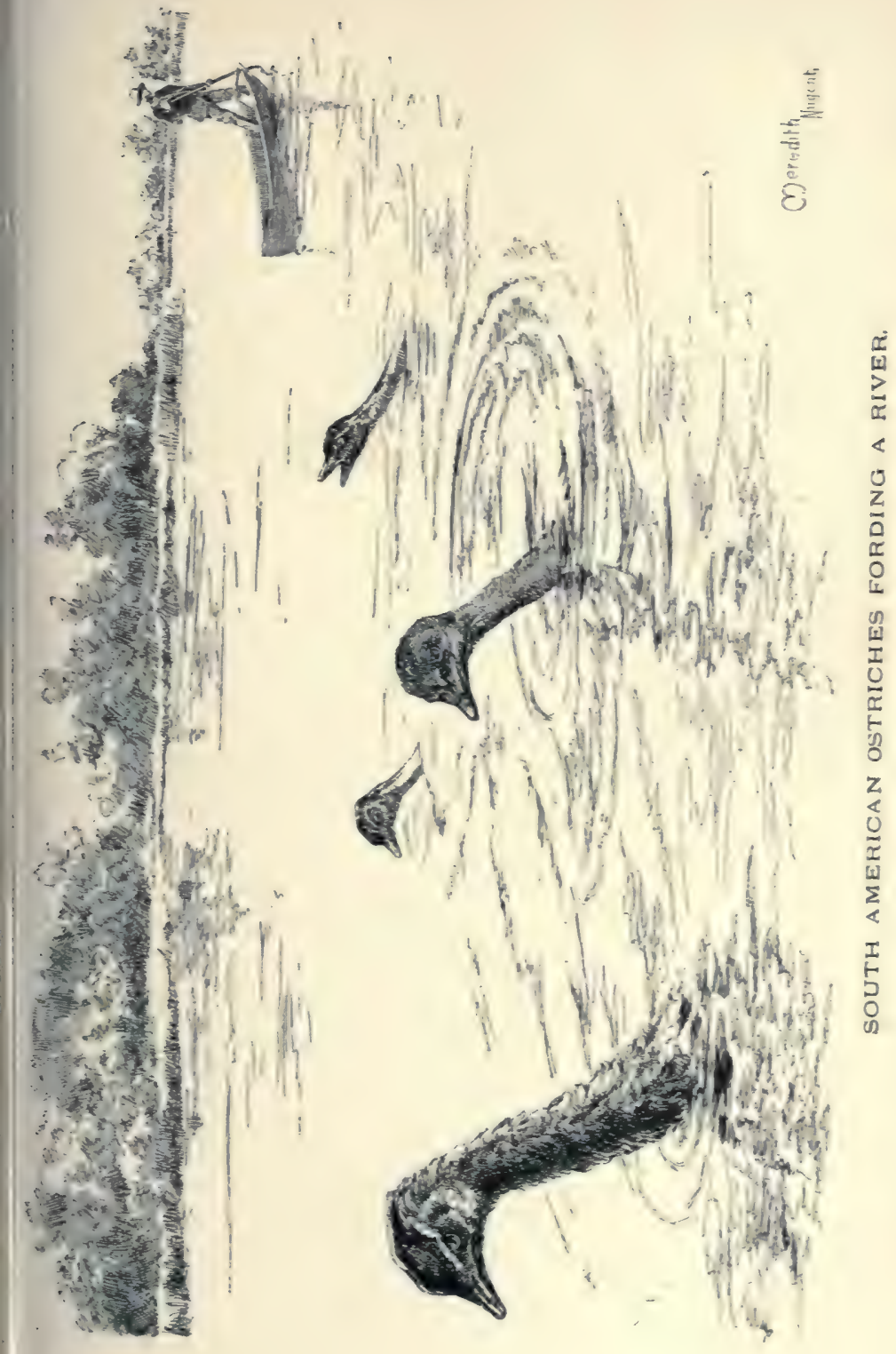



is confined to the La Plata country, while his species takes its place in Patagonia.

Among the strange animals observed here were the armadillos, four species being found; some were day travellers, while others only appeared at night, wandering over the plains. When approached the little creatures would roll up into a ball-like shape, and were then safe from all but human attack. In riding over the country they were frequently seen, but so rapidly did they dig and burrow that it was necessary to leap from the horse immediately, as their hind quarters would almost disappear before one could alight.

In the woods Darwin discovered a singular snake, Cophias, which, while without rattles, produced a warning almost similar to the rattlesnake. The tip of the tail was slightly enlarged, and as the snake moved through the brush it vibrated, and, striking against the reeds and grasses, produced a rattling noise distinctly audible six or seven feet distant. Here was also found a toad, with black upon the upper surface and the brightest vermilion below, living not in damp spots, but crawling about in the sunlight. A remarkable mimic among the lizards (Proctotretus) was noticed on the sea-shore, living on the open rocks, where its close resemblance to its surroundings protected it from various enemies, when attacked or alarmed. Darwin was astonished to see it stretch out its legs, stiffen its limbs, and feign death, even closing its eyes.

The interesting phase of life, hibernation, did not escape the observant eye of the young naturalist, 
and his notes on this one point were voluminous. When frost came at Bahia Blanca, few small animals were to be found except by digging, the lizards and insects having taken to the earth. Later they reappeared, and we here have an interesting example of the care and thoroughness which Darwin gave to all his work. In his log-book he writes: "During the first eleven days, whilst nature was dormant, the mean temperature, taken from observations made every two hours on board the Beagle, was $5 \mathrm{I}^{\circ}$; and in the middle of the day the thermometer seldom ranged above $55^{\circ}$. On the eleven succeeding days, in which all living things became so animated, the mean was $58^{\circ}$, and the range in the middle of the day between $60-70^{\circ}$. Here, then, an increase of seven degrees in mean temperature, but a greater one of extreme heat, was sufficient to awaken the functions of life. At Monte Video, from which we had just before sailed, in the twenty-three days included between the 26th of July and the Igth of August, the mean temperature from 276 observations was $58^{\circ} .4$; the mean hottest day being $65^{\circ} .5$, and the coldest $46^{\circ}$. The lowest point to which the thermometer fell was $4 \mathrm{I}^{\circ} \cdot 5$, and occasionally in the middle of the day it rose to $69^{\circ}$ or $70^{\circ}$. Yet with this high temperature, almost every beetle, several genera of spiders, snails and land-shells, toads and lizards, were all lying torpid beneath stones. But we have seen that at Bahia Blanca, which is four degrees southward, and therefore a climate only a very little colder, this same temperature, with a rather less extreme heat, was sufficient to awake all orders 


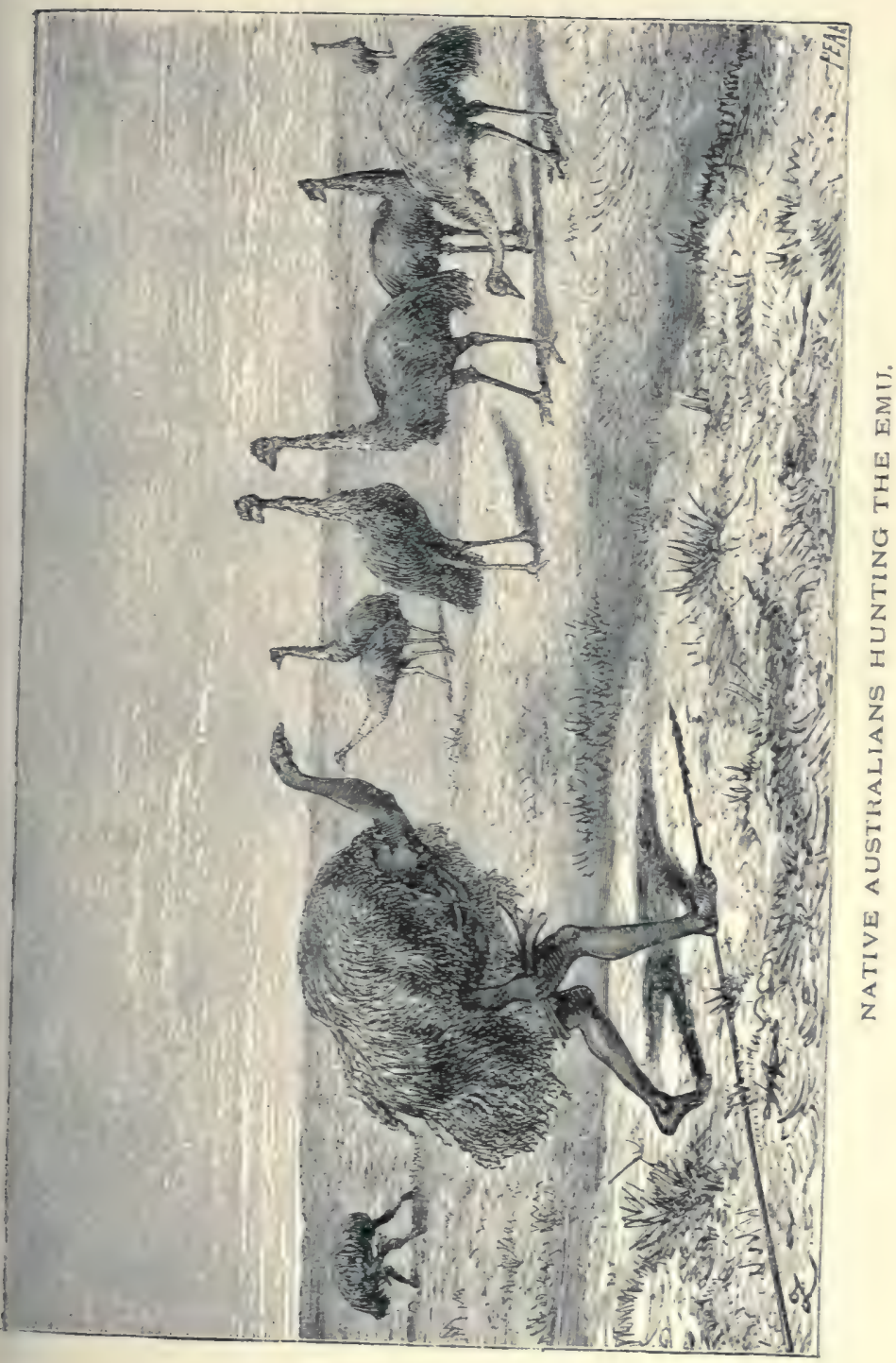



of animated beings. This shows how nicely the stimulus required to arouse hibernating animals is governed by the usual climate of the district, and not by the absolute heat. It is well known that within the tropics, the hibernation, or more properly xstivation, of animals, is determined, not by the temperature, but by the times of drought. Near Rio de Janeiro, I was at first surprised to observe, that, a few days after some little depressions had been filled with water, they were peopled by numerous full-grown shells and beetles, which must have been lying dormant. Humboldt has related the strange accident of a hovel having been erected over a spot where a young crocodile lay buried in the hardened mud. He adds, "The Indians often find enormous boas, which they call Uji, or water serpents, in the same lethargic state. To reanimate them, they must be irritated or wetted with water." "

While waiting for the Beagle at Bahia Blanca, Darwin witnessed some of the incidents of a war which was then in progress with the natives. The troops of the famous South American dictator and general, Rosas, had declared war against the Indians, and proposed to exterminate them if possible. A report received, that a squad of men had been murdered, occasioned no little excitement, and as a result a troop of three hundred men came in from the Colorado. They were not Spaniards, as Darwin expected, but "tame Indians" of the tribe of the Cacique Bernantio, and they afforded him as interesting material for study and observation as so many wild beasts. They were wild, reckless, even brutal, 
in the extreme. Many, crazed with intoxication, threw themselves upon the cattle slaughtered for them, and drank the streaming blood like so many brutes. The following day they started on the trail of the Indians, but the latter had made good their escape on the great pampas.

Darwin gives these Indians no little credit for skill and intelligence in obtaining results from what would be unintelligible to a white man. Thus they could examine the tracks of a thousand horses and tell how many were mounted by men, how many bore loads, whether they were fresh or fatigued, and whether they were going fast or slowly. For this they did not not need a fresh trail, one ten days old being read with equal ease. The Indians exhibited in their warfare a ferocity that would do credit to some of the red men of America. To show their nature, Darwin found that a man struck down seized his assailant by the thumb with his teeth and clung to it like a bull-dog while his eyes were torn out. Another feigned death, hoping an enemy might approach within reach of his knife, so that he might die red-handed. Another fled crying for mercy, and was seen trying to clear his bolas all the time. Darwin's informant nonchalantly said that he squared accounts with this fellow by striking him down with a sabre, then, dismounting, cut his throat with his knife-a horrible picture, and seemingly impossible in a civilised land.

That the Indians are disappearing before the Spaniards, as they have in North America, is a wellknown fact, and their extermination is only a matter 
of time. Darwin learned that in 1535 there were villages which contained two or three thousand people, while at the time of his visit the remnants were wanderers upon the face of the earth.

To show the remarkable equestrian skill of these Indians, Darwin cites an incident of the escape of a chief. Pursued by the Spaniards and closely pressed, he sprang upon a fresh white horse, which had neither saddle nor bridle, drew his little son up behind him, and dashed away at full speed. When fired at he threw an arm about the horse's neck and fell to one side, and though the follower changed horses three times, the Indian made good his escape.

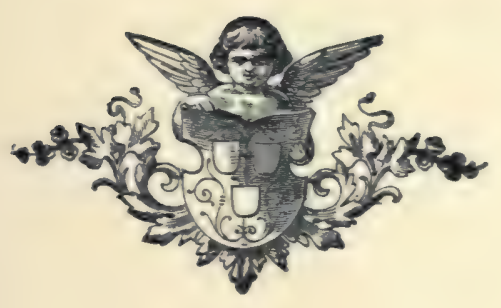




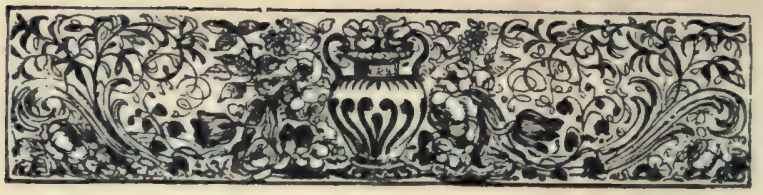

\section{CHAPTER VI.}

AMONG THE FOSSILS.

A Long Bullock Ride-Santa Fé-An Animal Collector-Large Fossils-Indian Superstitions-Darwin Ill-A Native DoctorGeology-Gigantic Armoured Animals-Drought - The ParanaThe Jaguar-Darwin a Prisoner-Swimming Horses-Shower of Butterflies-Phosphorescence.

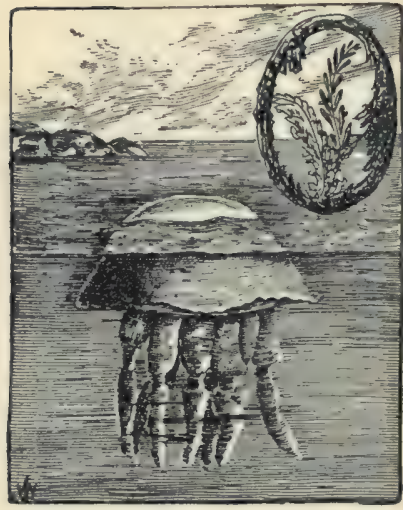

$\mathrm{NE}$ of the most interesting expeditions made by Darwin was from Buenos Ayres to Santa Fé, a distance of about three hundred miles. The conveniences for travelling were limited, the trip being made in bullock waggons - a tedious operation at best, but which had at least one commendable

feature: it afforded the naturalist ample opportunities to collect en route without the danger of being left behind should he stray from the road. This country was the home of the biscacha (Lagostomus trichodactylus), a little rodent somewhat resembling a rab- 
bit, but with a longer tail. Its ways and habits were of the greatest interest to the explorer, who made voluminous notes upon it. $\mathrm{He}$ cites as a singular circumstance that it was never seen east of the Uruguay, the great river forming a barrier to its progress, and that it was a very conspicuous feature in the zoölogy of the pampas region.

The biscacha attracted his attention particularly on account of its peculiar habit of collecting. Its holes were common about the pampas, and were conspicuous for the variety of curious articles found around them, gathered from far and near by the biscacha. The objects included stones, bones, lumps of earth, pieces of wood, thistle stalks, and various things. So confirmed is this habit that when the natives lose any thing along the road they immediately go to the holes of the biscacha, generally finding the missing articles in the heap. Thus Darwin was informed that spurs, whips, and even a gold watch which had been lost were recovered in this manner.

On October Ist the exploring party arrived at Rio Tercero, famous as the burying-ground for many large fossil animals. Among other specimens our young naturalist discovered two enormous skeletons, standing out in relief against the cliff-like sides of the Parana. They were in the last stages of decay, and the teeth only could be preserved.

It is interesting to note that the Indians believed the animals to be subterranean like the biscacha, from the fact that the skeletons were found underground, a supposition entertained by the Chinese 
and Siberians regarding the mammoth. At Santa Fé Darwin was much impressed with the great climatic differences which resulted from a change of merely three degrees of latitude. Everything suggested it: the costumes of the people, the cacti, and the superior size of certain trees.

At this place the naturalist was taken ill, and was attended by an old woman, who, if she did not succeed in curing him, added largely to his store of information on native remedies. He was troubled with severe headache, to cure which his nurse suggested that he bind an orange leaf on his temple, or split a bean and place one half on each side of the head. He also found that it was the custom to allow these medicines to cling upon the skin until they dropped off ; so that if a man or woman was seen with a bit of plaster or a leaf adhering to the temple, the inference was that they either were suffering with a headache or had had one a few days previous. Another curative was to kill two small dogs and bind them to an injured limb, while the common little hairless dogs he found were in no little demand to warm the feet of invalids - an animated plaster.

Darwin included the Governor of Santa Fé, one Lopez, among the natural curiosities of the place. He learned that his favourite sport was hunting Indians, he having recently destroyed forty or more, the adults being killed outright, while the children were sold at a rate of ten or twelve dollars apiece!

Across the Parana River, at Santa Fé Bajada, Darwin found one of the richest geological collect- 
ing fields of his entire voyage, and nearly a week was spent in working over what appeared to be the graves of innumerable monsters of the olden time. He discovered at the base of the lofty cliff a stratum containing sea-shells and sharks' teeth, while higher up came a red clay earth, which contained the remains of some remarkable forms.

Darwin read the explored section as the pages of a book, assuming that here was once a large bay of salt water, which had gradually been encroached upon, and into which the bodies of huge animals had been swept and buried. Out on the pampas beyond Bajada he came upon a worderful deposit, in which he unearthed the gigantic armour of an extinct armadillo-like animal, which he compared to a huge caldron, large enough for several men to find protection in. In the vicinity were the remains of a mastodon, showing that the elephant once roamed the plains. With these was a horse's tooth, of which Darwin wrote in his note-book: "This latter tooth greatly interested me, and I took scrupulous care in ascertaining that it had been embedded contemporaneously with the other remains, for I was not then aware that amongst the fossils from Bahia Blanca there was a horse's tooth hidden in the matrix, nor was it then known with certainty that the remains of horses are common in South America. Mr. Lyell has lately brought from the United States a tooth of a horse, and it is an interesting fact that Professor Owen could find, in no species, either fossil or recent, a slight but peculiar curvature characterising it, until he thought of comparing it with my specimen found 
here. He had named this American Equus curvidens. Certainly it is a marvellous fact in the history of the mammalia, that in South America a native horse should have lived and disappeared, to be succeeded in after ages by the countless herds descended from the few introduced with the Spanish colonists!"

In later years, Professor Marsh has shown that a long line of horses once lived in America, this being one of the most interesting and perfect links of evidence in the geological chain.

These remains suggested to the mind of Darwin many questions pregnant with interest, not the least of which was the geographical distribution of animals. He divided North and South America at the lofty table-land of Mexico, which would naturally affect migration, and saw in the separation two important and strongly contrasted zoölogical fields. "Some few species," he writes, " alone have passed the barrier, and may be considered as wanderers from the south, such as the puma, opossum, kinkajou, and peccary. South America is characterised by possessing many peculiar gnawers, a family of monkeys, the llama, peccary, tapir, opossums, and, especially, several genera of Edentata, the order which includes the sloths, ant-eaters, and armadillos. North America, on the other hand, is characterised (putting on one side a few wandering species) by numerous peculiar gnawers, and by four genera of hollowhorned ruminants, of which great division South America is not known to possess a single species. Formerly, but within the period when most of the now existing shells were living, North America 


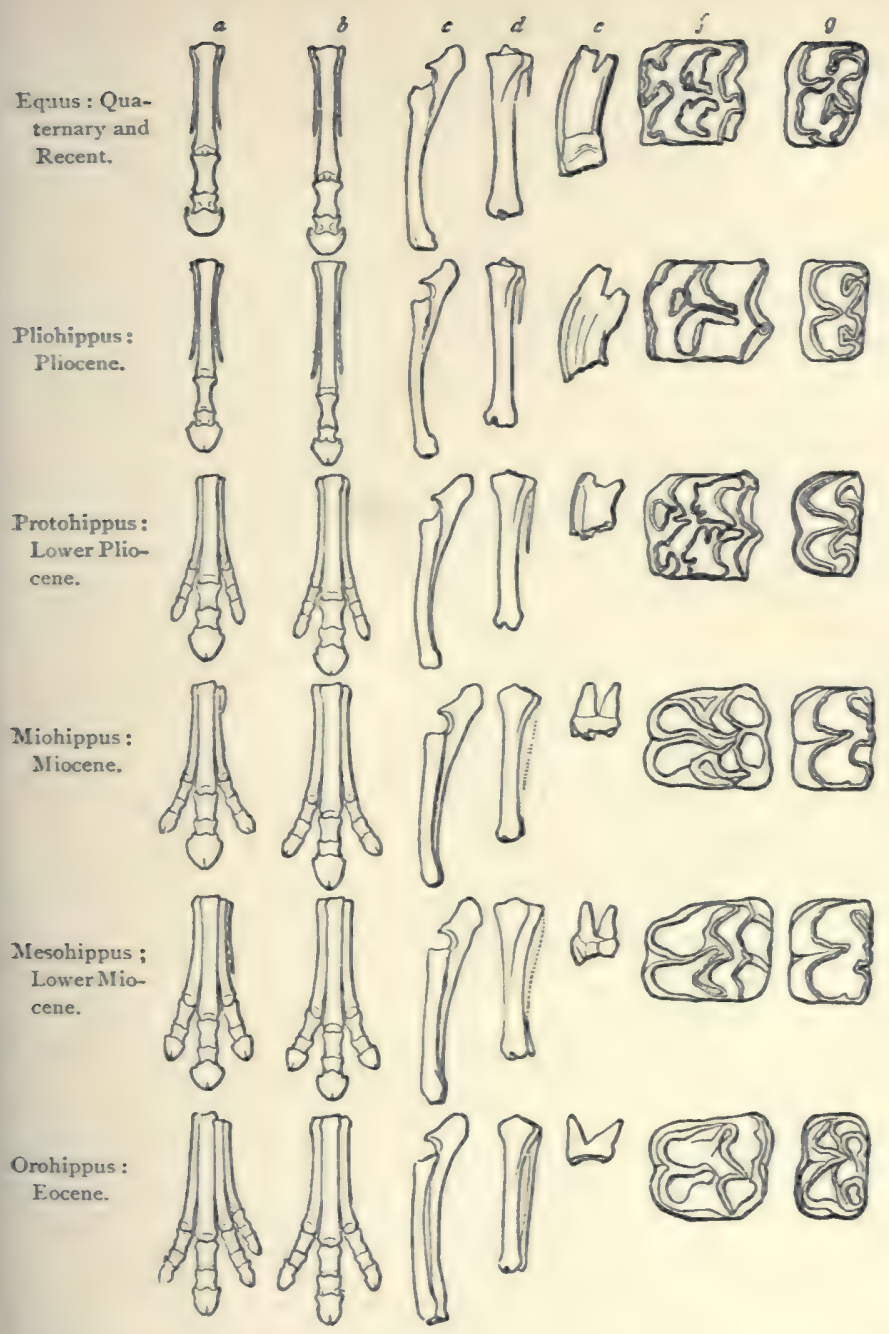

DIAGRAM ILLUSTRATING THE EVOLUTION OF THE HORSE.

Throughout $a$. is fore-foot; $b$, hind-foot; $c$, fore-arm; $d$, shank; e, molar on side-view; $f$ and $s$ grinding surface of upper and lovver molars. (After Marsh.) 

possessed, besides hollow-horned ruminants, the elephant, mastodon, horse, and three genera of Edentata. Within nearly this same period (as proved by the shells at Bahia Blanca) South America possessed a mastodon, horse, hollow-horned ruminant, and the same three genera of Edentata. Hence it is evident that North and South America, in having within a late geological period these several genera in common, were much more closely related in the character of their terrestrial inhabitants than they are now. The more I reflect on this case, the more interesting it appears: I know of no other instance where we can almost mark the period and manner of the splitting up of one great region into two well-characterised zoölogical provinces. The geologist, who is fully impressed with the vast oscillations of level which have affected the earth's crust within late periods, will not fear to speculate on the recent elevation of the Mexican platform, or, more probably, on the recent submergence of land in the West Indian Archipelago, as the cause of the present zoölogical separation of North and South America. The South American character of the West Indian mammals, seems to indicate that this archipelago was formerly united to the southern continent, and that it has subsequently been an area of subsidence.

"When America, and especially North America, possessed its elephants, mastodons, horse, and hollow-horned ruminants, it was much more closely related in its zoölogical characters to the temperate parts of Europe and Asia than it now is. As the remains of these genera are found on both sides of 
Behring's Straits and on the plains of Siberia, we are led to look to the north-western side of North America as the former point of communication between the Old and so-called New World. And as so many species, both living and extinct, of these same genera inhabit and have inhabited the Old World, it seems most probable that the North American elephants, mastodons, horse, and hollow-horned ruminants migrated, on land since submerged near Behring's Straits, from Siberia into North America, and thence, on land since submerged in the West Indies, into South America, where for a time they mingled with the forms characteristic of that southern continent, and have since become extinct."

While travelling through this region, Darwin learned that between the years $1827-30$, a terrible drought had occurred, during which myriads of animals had perished. $\mathrm{He}$ was told that wild deer became so thirsty that, devoid of fear, they came into the yards of native houses and endeavoured to obtain water from the wells; while game birds could be caught by the hand. It was estimated that one million head of cattle were lost during this time.

A most interesting deduction from facts obtained here was made by Darwin. He learned that many animals frenzied with thirst rushed down the banks of streams in herds, and were often so weak that they were unable to climb up again. Then followed the flood, and their bodies were washed away and buried. He concluded that several hundred thousand creatures may easily have been destroyed at 
certain points, and he quotes Azara as having seen the carcasses of a thousand wild horses in one place.

Darwin noticed that several of the small streams of the pampas appeared to be paved with a breccia of bones. "What," he asks, " would be the opinion of a geologist, viewing such an enormous collection of bones, of all kinds of animals and of all ages, thus embedded in one thick earthy mass? Would he not attribute it to a flood having swept over the surface of the land, rather than to the common order of things?"

His discerning eye immediately connected these modern fatalities with those that had occurred ages in the past, and saw a possible explanation of the great deposits of fossil bones found to-day mingled in such an inexplicable confusion.

In coming down the Parana, our young naturalist, who was inclined to wander ashore and visit the many islands which abounded, was warned to be on his guard against the jaguar, which was common here. The canebrakes of the river were the favourite haunts of the American tiger, and its tracks were found everywhere. When their natural food is scarce they do not hesitate to attack man. A sailor fought with one on the deck of a vessel, losing his arm in the contest; while a few years previous to Darwin's visit, a "man-eater" found its way into the church at Santa Fé and killed two padres, one after the other, as they entered, and badly wounding a third. The naturalist was shown certain trees which had been scratched by the tiger, the marks being so frequent that the natives were in the habit of look- 
ing at the trees to see if a jaguar was near. The common cat has a similar habit, as well as the black bear, especially in the Gulf States of North America, and Darwin believed the same was true of the puma from marks he had seen, and suggested that it was done to tear off the ragged points of their claws, and not to sharpen them as the Gauchos thought.

The sail down the Rio Parana was enlivened by one incident not on the programme. Upon reaching the mouth of the river, Darwin landed at the little town of Las Conchas, hoping to reach Buenos Ayres sooner, and there was made a prisoner. A revolution had suddenly broken out, and no one was allowed to leave the place, so that he could not even return to the vessel. After many disappointments, and much red tape, an audience was obtained with the commanding officer, when, upon mentioning that he had received courtesies from Rosas, he was allowed to pass the line, and escorted to the city, where he took passage in a small vessel for Monte Video.

Between this city and Colonia del Sacramiento an opportunity was afforded of observing the skill with which horses swam streams. Darwin's own animal readily passed over rivers a quarter of a mile wide, while an instance was related of a native horse which swam from a wreck a distance of nearly seven miles.

Darwin observed a Gaucho swimming a stream with his horse, holding the animal by his tail, and refers to the fact that he himself was towed across a river with three others in a boat in the same manner. 
On an estancia at the Arroyo de San Juan, Darwin met with a curious breed of cattle, which aroused his interest and curiosity to a high degree. They were called nata, or niata, and seemed to him to bear the same relation to their tribe in general that the bulldog does to its fellows of the canine race. "The forehead," he says, "is very short and broad, with the nasal end turned up, and the upper lip much drawn back; their lower jaws project beyond the upper, and have a corresponding upward curve: hence their teeth are always exposed. Their nostrils are seated high up, and are very open; their eyes project outwards. When walking they carry their heads low, on a short neck; and their hinder legs are rather longer, compared with the front legs, than is usual. Their bare teeth, their short heads, and up-turned nostrils give them the most ludicrous, self-confident air of defiance imaginable."

Darwin secured the skull of one of these oxen, which is now in the museum of the College of Surgeons, London, and upon investigation learned that the singular breed originated among the Indians south of the Plata. He remarks that it is a curious fact that an almost similar structure to this abnormal one of the niata is found in the fossil sivatherium.

Our young naturalist was always on the look-out for good collecting fields, and was in constant receipt of reports from the natives of wonders of various kinds, which in many instances amounted to nothing. Hearing of some gigantic bones, he visited a ranch on the Sarandis, a small tributary of the Rio Negro, where he found a fine head of the toxodon, 
which he purchased for twenty-five cents, and ultimately conveyed safely to England. He judged from the specimens found here that the huge animal was common at one time. With it he discovered more specimens of the gigantic armadillo-like animal, and the massive skull of a mylodon; and, more remarkable still, he found that the bones of the latter were so fresh that they retained seven per cent. of animal matter.

Darwin was impressed by the vastness of the deposit here, and he estimated that it would be impossible to draw a line through the pampas in any direction without striking a skeleton of some kind. The natives were familiar with the remains, and often named places for them : thus an elevation was called "the hill of the giant," and a river "the stream of the animal." The investigations of the naturalist were not confined to the inanimate and the lower animals alone; while constantly at work in the departments of his choice, he made extensive studies of the social life of the people, giving a graphic description of their life and habits.

$\mathrm{He}$ found the Gauchos obliging and polite to strangers, but among themselves belligerent, and with little or no regard for life. Every man carried a knife, and murders and affrays were common occurrences. At one town he asked two men why they did not work; one replied that he was too poor, while the other gave as an excuse that the days were too long. This was characteristic of a country, where justice was a mockery and the grossest crimes went unpunished if the offender was rich. 
On December 6th, Darwin again set sail in the Beagle, after a most successful trip through the country, and carried aboard collections that well represented the fauna of the locality. Being at sea, he found, did not entirely prevent the collection of shore animals. Thus one evening, when ten miles off shore, near the bay of San Blas, the Beagle was fairly surrounded by a shower of butterflies, which extended as far as the eye could reach. Even with a telescope no spot could be discovered free from them, so their numbers can be imagined. The sight was so marvellous that the men remarked that it was snowing butterflies.

Darwin found it difficult to explain the presence of the insects off shore, as there was no storm or squall which could have driven them out to sea.

Upon various occasions insects were taken while at sea, some in the nets which were dragged astern. The most remarkable case recorded is of a grasshopper, which flew aboard the Beagle when she was three hundred and seventy miles from land, off the African coast. Spiders were captured sixty miles from shore, all sailing on little balloons made of their own silk. When they came aboard it was found that they were extremely thirsty, and eagerly drank from drops of water.

These spiders were, according to Darwin, the aëronauts of the tribe, and he devoted many hours to them. When wishing to rise, the abdomen was elevated and several skeins of silk ejected, which passed up into the air for several yards in the ascending current, and then, releasing its hold, the spider 
was carried away. During the passage south numbers of interesting marine animals were added to the collections, among which were singular crabs with suckers for clinging to other animals. The phosphorescent forms were particularly numerous, of which he writes:

"While sailing a little south of the Plata on one very dark night the sea presented a most wonderful and beautiful spectacle. There was a fresh breeze, and every part of the surface, which during the day is seen as foam, now glowed with a pale light. The vessel drove before her bows two billows of liquid phosphorus, and in her wake she was followed by a milky train. As far as the eye reached the crest of every wave was bright, and the sky above the horizon, from the reflected glare of these livid flames, was not so utterly obscure as over the vault of the heavens.

"As we proceed further southward the sea is seldom phosphorescent; and off Cape Horn I do not recollect more than once having seen it so, and then it was far from being brilliant. This circumstance probably has a close connexion with the scarcity of organic beings in that part of the ocean. After the elaborate paper by Ehrenberg on the phosphorescence of the sea, it is almost superfluous on my part to make any observations on the subject. I may, however, add that the same torn and irregular particles of gelatinous matter, described by Ehrenberg, seem, in the southern as well as in the northern hemisphere, to be the common cause of this phenomenon. The particles were so minute as easily to 
pass through fine gauze; yet many were distinctly visible by the naked eye. The water, when placed in a tumbler and agitated, gave out sparks, but a small portion in a watch-glass scarcely ever was luminous. Ehrenberg states that these particles all retain a certain degree of irritability. My observations, some of which were made directly after taking up the water, gave a different result. I may also mention that, having used the net during one night, I allowed it to become partially dry, and having occasion twelve hours afterwards to employ it again, I found the whole surface sparkled as brightly as when first taken out of the water. It does not appear probable, in this case, that the particles could have remained so long alive. On one occasion, having kept a jelly-fish of the genus Diancea till it was dead, the water in which it was placed became luminous."

Since Darwin made his famous trip scores of animals have been added to the list of those which emit light, yet the true secret of the illumination has not yet been determined. 


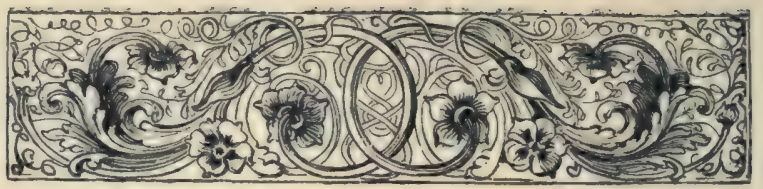

\section{CHAPTER VII.}

\section{THE LAND OF GIANTS.}

The Patagonians-Guanaco Hunting-Singular Burial Customs-A Horse with a Proboscis-Extinction-Up the Santa Cruz-Puma Tracks-Catching the Condor-Falkland Islands-Among the Glaciers-The Fuegians-Giant Sea-Weed and Its Work.

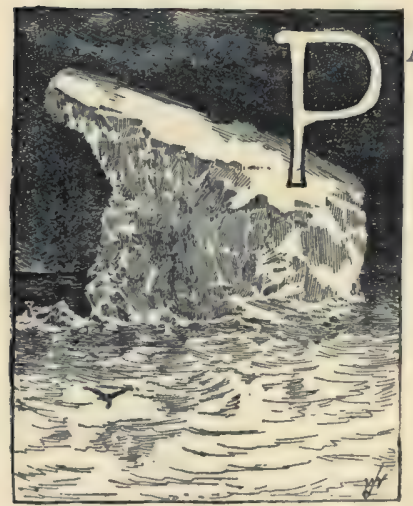

ATAGONIA was looked forward to by Darwin with no little pleasure, and on December $22 \mathrm{~d}$ the Beagle cast anchor in the harbor of Port Desire, near the ruin of an old Spanish settlement. The animal life here was somewhat limited, as was the flora, the most characteristic animal being the curious little wild llama or guanaco, which was found in large herds on the plains. They were shy, but Darwin took advantage of their curiosity by making various motions and assuming strange postures, and succeeded in shooting a number. When discovered several miles off they immediately took fright and ran, while one, 
surprised near at hand, moved away slowly. Another which Darwin met with on the mountains squealed, snorted, and pranced about when he approached, defying him, as it were.

The guanaco is altogether a curious creature, and our naturalist found that they actually had certain places in which to die. In one spot he counted the remains of at least twenty of these animals in a restricted area. Referring to this in his note-book he says: "I do not at all understand the reason of this, but I may observe that the wounded guanacos at the Santa Cruz invariably walked towards the river. At St. Jago, in the Cape Verd Islands, I remember having seen in a ravine a retired corner covered with bones of the goat; we at the time exclaimed that it was the burial-ground of all the goats in the island. I mention these trifling circumstances because in certain cases they might explain the occurrence of a number of uninjured bones in a cave, or buried under alluvial accumulations; and likewise the cause why certain animals are more commonly embedded than others in sedimentary deposits."

Among the interesting fossils found in Patagonia was the skeleton of the macrauchenia-an animal equalling a camel in size, having a long neck and, according to Bermeister, a South American geologist, a short trunk like that of an elephant. These singular discoveries were of great import to Darwin. We find him reflecting upon the causes which produced their extinction, and it is interesting to note how correct were his deductions. He was impressed 
with the evidences of change that were apparent on every hand. The remains which he found showed that in the past the country was peopled with a race of giants which had given way to pigmies. The land which once trembled under the tread of the huge sloth, and saw the monster armadillo, was now roamed by the little guanaco. Darwin prover that the huge forms were contemporaneous with the shells which then flourished in the ocean, consequently were of comparatively recent date. What, then, was the cause of their extinction? Darwin's first thought, and a most natural one, was that some great cataclysm had taken place which destroyed entire races in Patagonia and Brazil. $\mathrm{He}$ argued from the results of his investigations that all the physical features were the result of gradual changes, consequently it could not have been a change of temperature at once sudden and death-dealing. Many of the animals which passed away so mysteriously existed after the ice age, which has been supposed to have been the exterminator. What, then, could have been the cause of such widespread destruction? That early man might have been the destroyer evidently passed through the mind of the young naturalist, as he says: "Did man, after his first inroad into South America, destroy, as has been suggested, the unwieldy Megatherium and the other Edentata?"

Yet he believed the extinction of the smaller forms, as the little tucutuco, could not have been effected in this way. He considered an extreme drought and reflected upon its possibilities, also 


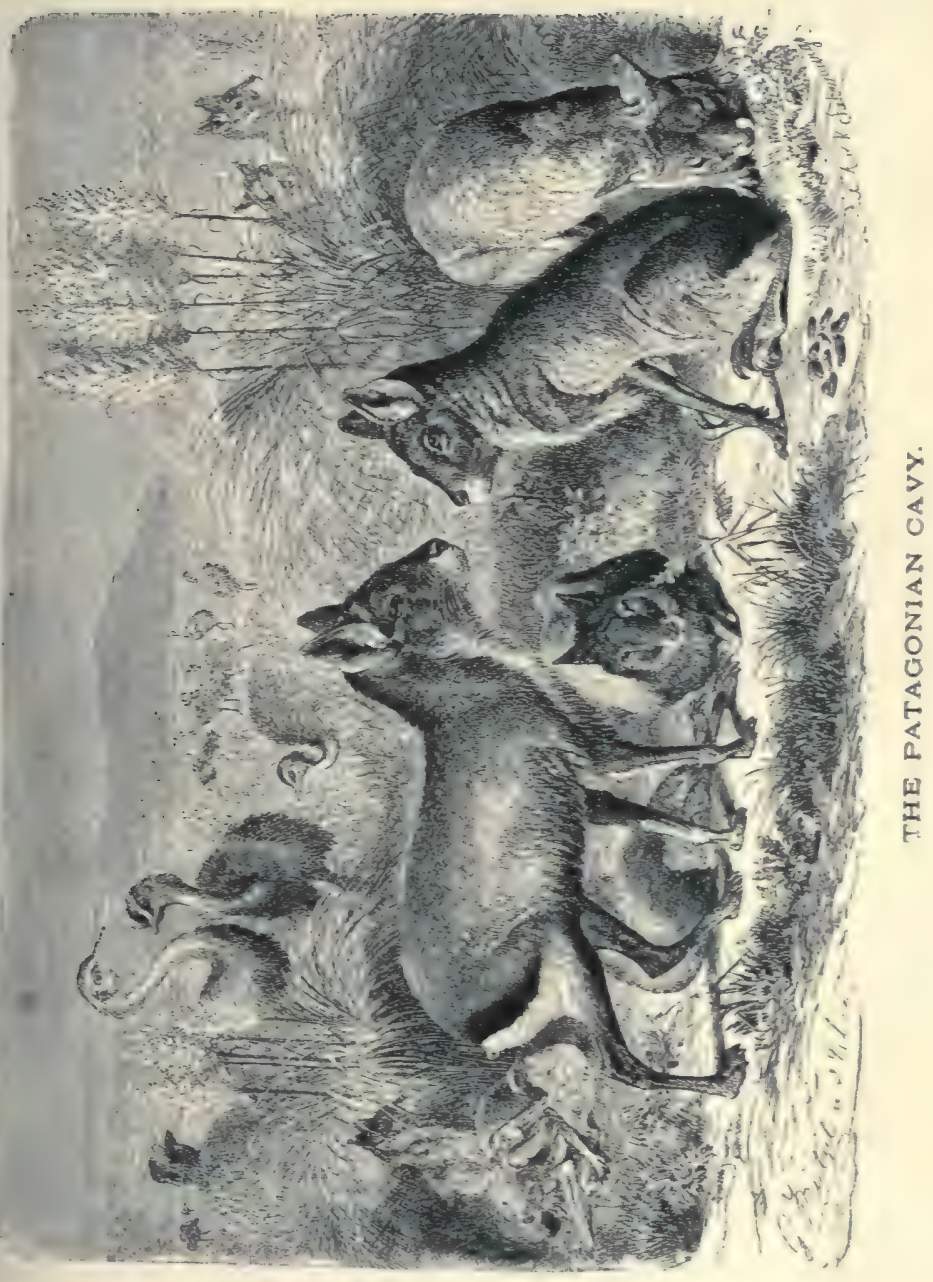



upon the failure of a food supply. "Did those plains fail of pasture, which have since been overrun by thousands and hundreds of thousands of the descendants of the stock introduced by the Spaniards? Have the subsequently introduced species consumed the food of the great antecedent races? Can we believe that the Capybara has taken the food of the Toxodon, the Guanaco of the Macrauchenia, the existing small Edentata of their numerous gigantic prototypes? Certainly no fact in the long history of the world is so startling as the wide and repeated exterminations of its inhabitants."

In these thoughts and conclusions of the young naturalist we see the germs of the genius that resulted long after his trip in the greatest of his works, the "Origin of Species." He did not assign any direct cause for their disappearance, but concluded that the laws of nature regulated the increase and decrease of forms. For some the conditions were favourable for perpetuation; for others they were not, so that in one direction we might find rapid multiplication, and in another a tendency to extinction or running out.

The reasoning of Darwin at this time is so prophetic of his later work that it will add to the interest to quote his words as given in his note-book: "In the cases where we can trace the extinction of a species through man, either wholly or in one limited district, we know that it becomes rarer and rarer, and is then lost; it would be difficult to point out any just distinction between a species destroyed by man or by the increase of its natural enemies. The 
evidence of rarity preceding extinction is more striking in the successive tertiary strata, as remarked by several able observers; it has often been found that a shell very common in a tertiary stratum is now most rare, and has even long been thought to be extinct. If, then, as appears probable, species first become rare and then extinct-if the too rapid increase of every species, even the most favoured, is steadily checked, as we must admit, though how and when it is hard to say-and if we see, without the smallest surprise, though unable to assign the precise reason, one species abundant and another closely allied species rare in the same district, why should we feel such great astonishment at the rarity being carried a step further to extinction? An action going on on every side of us, and yet barely appreciable, might surely be carried a little further without exciting our observation. Who would feel any great surprise at hearing that the Megalonyx was formerly rare compared with the Megatherium, or that one of the fossil monkeys was few in number compared with one of the now living monkeys? and yet in this comparative rarity we should have the plainest evidence of less favourable conditions for their existence. To admit that species generally become rare before they become extinct-to feel no surprise at the comparative rarity of one species with another, and yet to call in some extraordinary agent and to marvel greatly when a species ceases to exist, appears to me much the same as to admit that sickness in the individual is the prelude to death-to feel no surprise at sickness-but when the sick man 


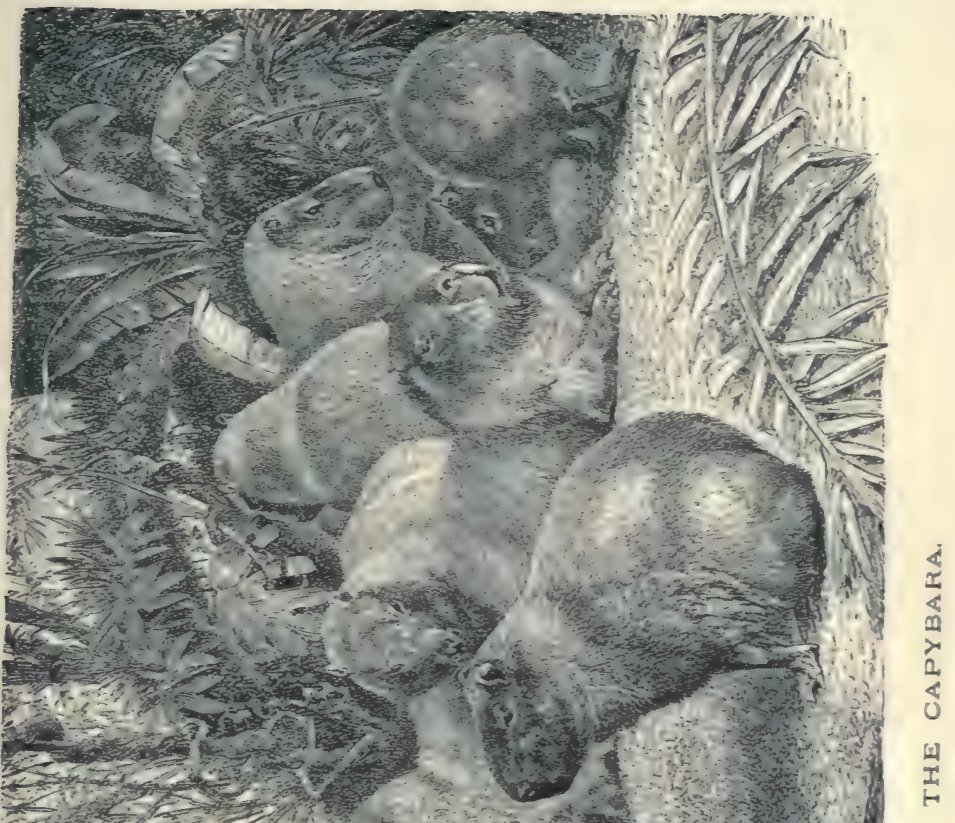



dies, to wonder, and to believe that he died through violence."

An interesting trip made in this country was up the Santa Cruz River, concerning which very little was known, Europeans having gone but thirty miles from the mouth in previous voyages. The expedition into the unknown land was composed of three whale-boats provisioned for three weeks and manned by Darwin, an officer, and twenty-five men as a guard against Indians. The river was about one third of a mile wide, seventeen feet deep, and very rapid, terraces rising on either side, forming a valley nearly ten miles in width. It was hard and tedious work, as canal tactics had to be adopted; the boats were fastened together, the men walking along the banks and hauling them by a rope. A few days out they saw smoke, and found evidences of a camp. Puma tracks were seen everywhere, and an occasional guanaco with its neck broken told of the power of this great cat. The geology of the region was carefully studied by the naturalist and was of no little interest. He found deposits of lava one hundred and twenty feet in thickness, and later two hundred feet thicker, showing that a mighty volcanic eruption had taken place at some early time.

When well up the river our hero shot his first condor, the bird measuring from tip to tip of wings eight and a half feet. Near the river, among the basaltic cliffs, he discovered a rookery of the noble birds, and as he approached the edge of the precipice he saw thirty or more fly away at once, presenting a magnificent spectacle. He was particularly 
observant of their flight, and in a letter, written to the late Dr. J. B. Holder, expressed his astonishment that these birds could circle about, moving up and down, covering great distances without apparently vibrating the wings.

While the condors live upon carrion, they often attack young animals; hence the natives trained their dogs to dash out and bark as they approached.

The Indians caught them in an ingenious way: they surrounded a dead animal with a fence of sharp sticks, and when the condor became gorged with food, rushed in on horseback and shut the enclosure before the bird could escape. Another method witnessed by Darwin consisted in creeping up to where the birds roosted and dropping a noose over their heads while they were asleep.

In March, 1833, the party arrived at East Falkland Island, in Berkeley Sound, where wild-cattle hunting formed one of the exciting incidents. Many hard and fatiguing rides were taken, on one of which Darwin states that his horse fell no less than six times, and frequently all the animals ridden by the party were floundering in the mud. In Berkeley Sound Darwin found a curious geological feature, nothing less than a river of stones, the valley being made up of rocks thrown together in the wildest manner possible and apparently flowing down to the sea. The width of the stream varied from a few hundred feet to a mile, and was of unknown depth, water being distinctly heard trickling far below the surface. In one valley south of Berkeley Sound one of these stone rivers was seen, where for a quarter 


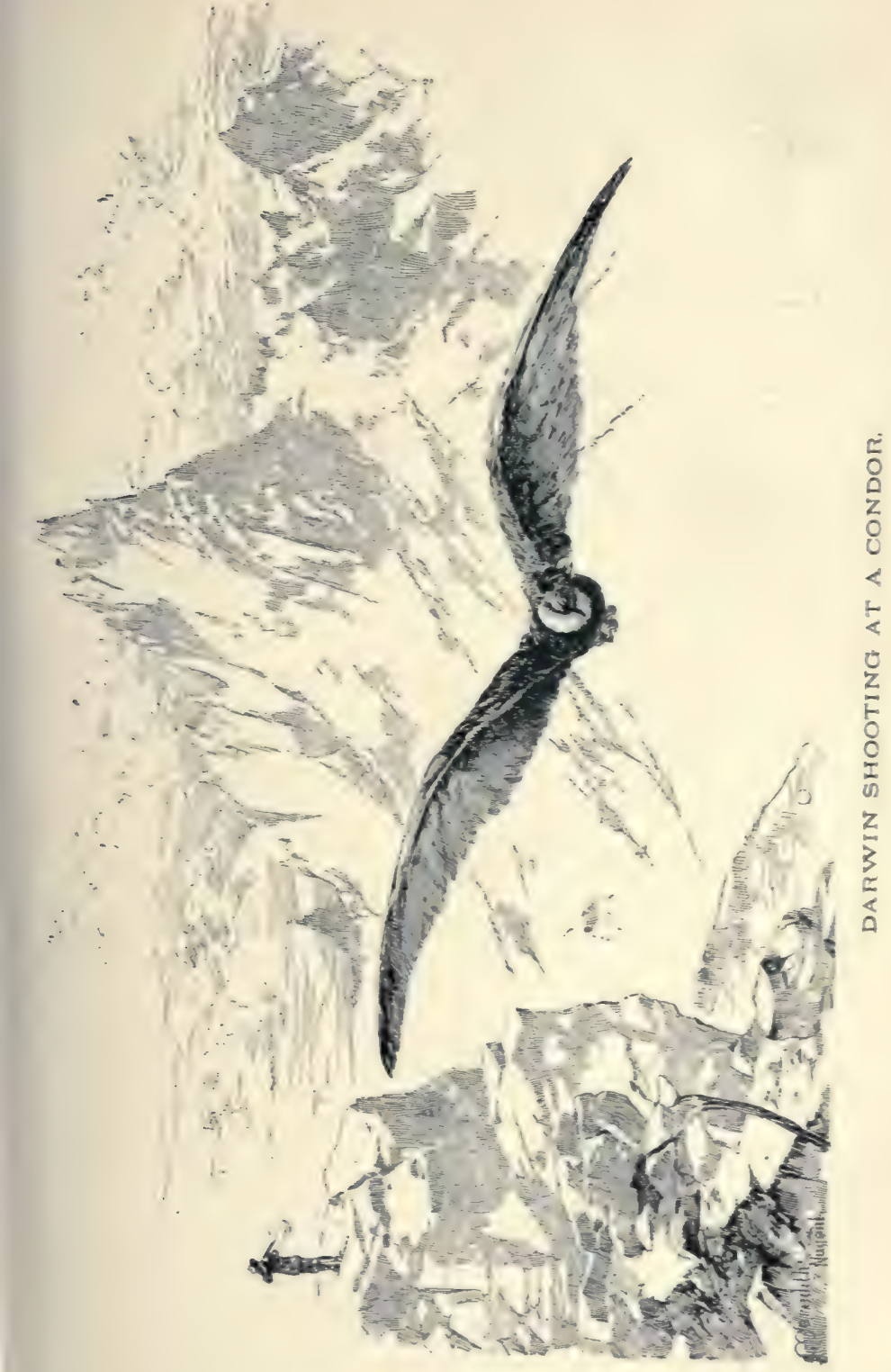



of a mile the observer crossed without stepping from the rocks, some of which were so large that protection from the rain was found beneath them. The native inhabitants of Tierra del Fuego were looked for with interest, and the first view of them was had at the Bay of Good Success, a group appearing on the shore waving their tattered garments at the voyagers. These were the popularly called giants, as the natives of the land were supposed to be much larger than any others, and are so to a certain extent. A boat was sent ashore and communication held with them. They were fine lusty fellows fully six feet in height, and giants when compared to the natives previously seen. They were of a dirty copper color, and, though the climate was rigorous, clothed in a simple guanaco skin thrown over the shoulders.

Darwin presented an old man with some slight gift, at which he patted the donor's breast, uttering a sound like that of calling chickens, then bared his breast for a return of what was considered a courtesy. Darwin noticed that they were skilful mimics, as every action of his, even a yawn, was repeated, and, more remarkable yet, they repeated the words and sentences spoken to them with exactness.

The visit to these people had a significance, as aboard the Beagle were several Fuegians, who had been taken to England on a previous trip to be educated and civilised,- - philanthropic act of Captain Fitz-Roy, who was now bringing them back with a missionary, who proposed to live with their people and undertake the work of elevating them to a 
higher plane. The result was that the educated natives were robbed of all their property by their relatives, and when visited some years later were found to have lapsed again into savages.

At Beagle Inlet Darwin had an adventure with a glacier. Wishing to examine it the boat was hauled upon the beach, and the masses of ice watched as they fell away. Finally a large berg became detached and fell with a thundering crash, sending an immense wave in upon the beach. Darwin and party rushed for the boats to save them if possible, reaching them just as the wave came crashing in, knocking one of the men over and lifting their boat high in air, fortunately doing no damage, as they were over one hundred miles from the Beagle.

At Cape Gregory some fine types of the giant natives were seen, though Darwin says they appeared larger than they really were from their style of dress. They averaged six feet in height, some of the men being taller, and as Darwin describes them as being the tallest people he met on the entire voyage around the world, they may be considered the tribal giants of the human race.

In referring to them he says: "I believe, in this extreme part of South America, man exists in a lower state of improvement than in any part of the world. The South Sea Islanders of the two races inhabiting the Pacific are comparatively civilised. The Esquimau, in his subterranean hut, enjoys some of the comforts of life, and in his canoe, when fully equipped, manifests much skill. Some of the tribes of Southern Africa, prowling about in search 


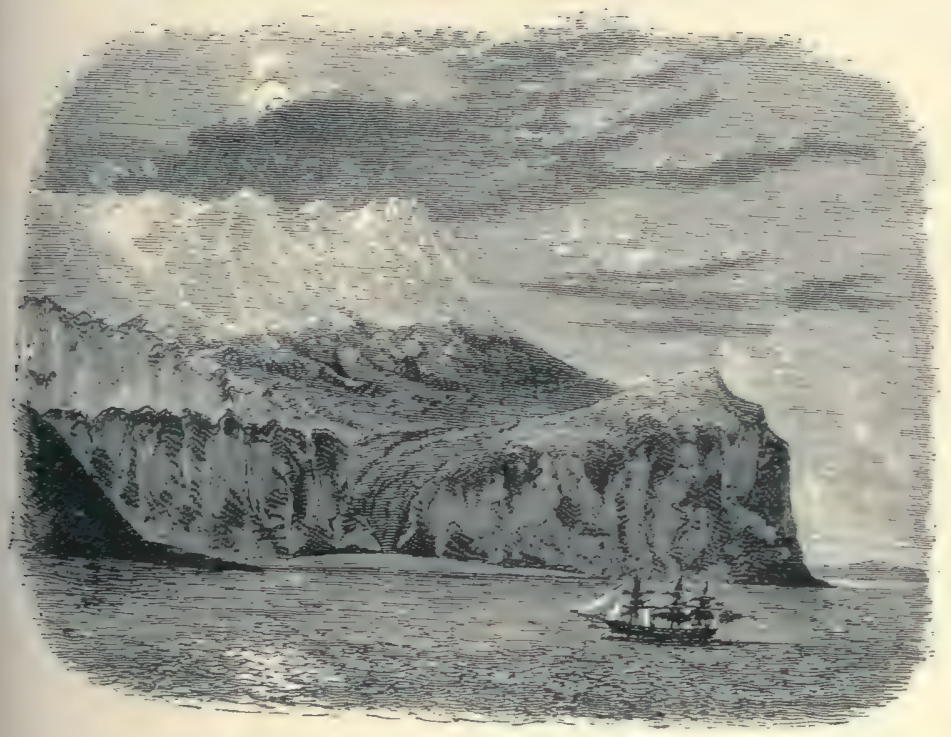

CAPE FROWARD, STRAITS OF MAGELLAN. 

of roots, and living concealed on the wild and arid plains, are sufficiently wretched. The Australian, in the simplicity of the arts of life, comes nearest the Fuegian; he can, however, boast of his boomerang, his spear, and throwing-stick, his method of climbing trees, of tracking animals, and of hunting. Although the Australian may be superior in acquirements, it by no means follows that he is likewise superior in mental capacity; indeed, from what I saw of the Fuegians when on board, and from what I have read of the Australians, I should think the case was exactly the reverse."

Darwin found the zoology of this region more or less disappointing, though the ocean and rocky shores gave protection to numbers of interesting animals, which he added to his collection. He observed that the giant sea-weed, Macrocystis pyrifera, flourished off shore in the midst of a terrific sea, and he at once recognised in it an important factor in the preservation of animal life. He found it growing in water three hundred and sixty feet deep, reaching to the surface, and proved that it formed a natural breakwater, and gave shelter in its leaves and branches to innumerable animals, from delicate shells and crustaceans up to fishes. Indeed he considered that the actual existence of the natives depended upon it, as he says: "Amidst the leaves of this plant numerous species of fish live, which nowhere else could find food or shelter; with their destruction the many cormorants and other fishing-birds, the otters, seals, and porpoises, would soon perish also; and lastly, the Fuegian savage, the miserable lord of this 
miserable land, would redouble his cannibal feast, decrease in numbers, and perhaps cease to exist."

Tierra del Fuego was found to be the land of the glacier, and numerous opportunities were afforded to study them, many valleys being filled with these moving rivers of ice which formed in the low ranges of mountains. Some of them gave their icebergs to the sea with blasts and roars like the broadside of a ship of war. In Eyre's Sound Darwin saw fifty ice. bergs of large size floating about at once, borne from the adjacent glaciers. One of the largest observed, and the farthest from the Pole, was in the Gulf of Penas, where the ice river was fifteen miles in length and seven broad. Darwin's studies on these glaciers, and the laws which govern them, were of no little value to scientists, and many of the theories regarding their action which have found place as facts originated with him.

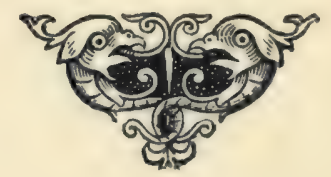




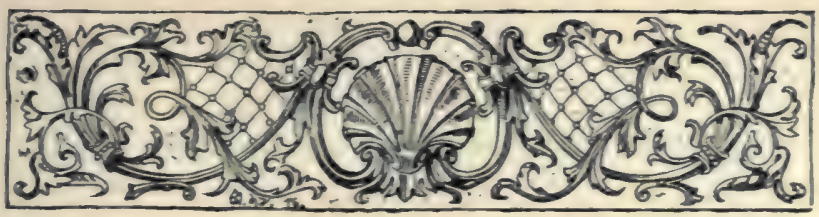

CHAPTER VIII.

THE FOOT OF THE ANDES.

At Valparaiso-Andean Life-An Old School-mate-An Ocean Bottom-In the Mines-Hot Springs-Darwin Excites SuspicionVolcanoes-Tame Birds-The Myopotamus-Predaceous Gulls -Birds Killed by Them.

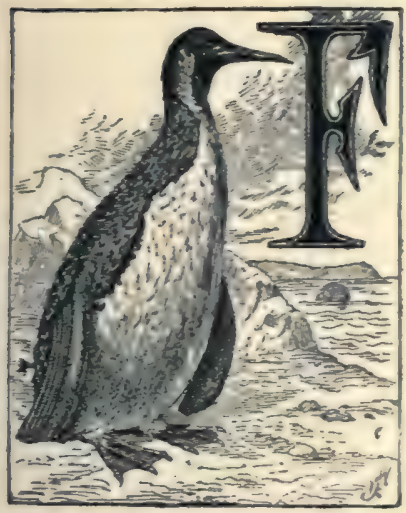

ROM the barren, desolate shores of Tierra del Fuego and Patagonia the Beagle sailed for Valparaiso, where Darwin was to study the features of life along the base of the Andes. $\mathrm{He}$ was enthusiastic over the change, finding in the dry, bracing air and clear blue skies entirely new conditions. The general aspects of the country reminded him of Santa Cruz in Teneriffe, and from the bay he had his first glimpse of the Andes proper, and gazed upon the great volcano of Aconcagua, with an altitude estimated by his fellow-officers at 23,000 feet. 
At Valparaiso Darwin found an old school-mate, with whom he took up his residence, making daily trips into the surrounding country, ever showing that care and earnest research that forms so prominent a feature in all his work. One of the rides which he took along the base of the Andes was to the hacienda of Quintero, for the purpose of examining an ancient section of ocean bottom, portions of which were burned for the lime its shells contained. The mass was almost entirely composed of shells, while the mould which covered them was found, under microscopical examination, to be marine mud, made up of minute portions of organic matter. In this deposit the young naturalist saw further evidence of the vast upheaval which had taken place here, and the presence of this ancient beaeh thirteen hundred feet above the present ocean level was viewed by him with no little interest and wonder.

Many mines were visited in the neighbouring country, there being at that time a mining craze for gold and copper. The life of the miners was one to be commiserated. They began work at daylight, continuing until dark, with scarcely any intermission. They received for their labour five dollars per month, and food which consisted of the following: For breakfast, sixteen figs and two small loaves of bread; dinner, boiled beans; for supper, roasted wheat grain. They rarely tasted meat.

A visit was made by Darwin to the hot springs of Cauquenes, where mineral water of some little medicinal value bursts forth from the rocks. In 1822 an earthquake stopped the flow, which did not re- 
commence until the following year. The temperature was said to change according to the season; thus in summer it was hotter than in winter, a condition which the young naturalist found difficult to explain. On his way to the Yaquil mines Darwin passed by the famous Lake Tagua-tagua, in the surface of which are several islands which float about, carrying various animals with them. The wind governs their position entirely; sometimes they are upon one side of the lake, sometimes upon the other. The Yaquil miners were found to be in even a worse condition than those previously referred to. The men, often very young, were obliged to descend four hundred and fifty feet, and bring up two hundred pounds of the mineral. Their food consisted of boiled beans and bread, and their pay was about twenty-eight shillings per month. Stealing was prevented by deducting from the pay of all the men the value of the ore taken.

Near these mines Darwin discovered some ancient Indian ruins, and secured some of the perforated stones now so common in collections from these countries. During his stay here an old German collector of natural objects called upon him. A Spaniard happening in at the same time, asked the former in the native language if he did not consider it very singular that the King of England should send a man to their country to pick up lizards and beetles. The German, after some consideration, replied: "No man is so rich as to send out people to pick up such rubbish. I do not like it. If one of us were to go to England and do such things, do you not 
think the king would very soon send us out of his country?"

This conversation, which was repeated to the young English collector, amused him not a little. The Spaniard was evidently much interested in the same work as Darwin, as some time after he collected some caterpillars, which he left in charge of a young girl to feed that he might observe them when they came out. This fact becoming rumoured through the town, the governour and padres met, and concluding that there was something heretical about the unfortunate would-be naturalist, he was thrown into jail, which probably put a stop to all enthusiasm in the direction of natural history research.

Here Darwin had many opportunities to observe and study the habits of the puma. He learned that it ranged over the entire continent, and he saw its foot-prints 10,000 feet up in the Cordillera of Chili. Its food in La Plata was the ostrich, deer, and various small animals. In Chili it frequently killed horses and cattle, and occasionally man. Its method of attack was to spring upon the shoulders of it prey ; then drawing the head back until the neck of the animal was broken. When its meal was finished the big cat would lie by the body, and thus was often discovered, as the condors flew down to share the feast, and were in turn observed by the hunters, who unloosed their dogs and attacked the big game.

In the open country the puma was lassoed, and dragged by the horses until it was helpless, while in other cases it was driven into trees and shot.

The puma was famous here for its cunning in 
avoiding enemies. Often to throw dogs from its trail it would leap suddenly to one side, and run backward on the trail, effectually evading them.

A portion of the work of the Beagle was the survey of the islands of the Chonos Archipelago, which gave the young naturalist an opportunity to examine what was a rich zoölogical region. He made his first excursion over the island of Chiloe on horseback, which was made fairly possible by the log-roads which were found everywhere. The natives were astonished at the boats and men, and thought it an attempt to capture the island. From the village of Chacao the volcano of Osorno was seen belching smoke and cinders, which, in contrast to the snow which covered it, presented a magnificent spectacle. Near this was the volcano of Corcovado, emitting jets of steam and smoke. Near by was still another, so that three active volcanoes of large size were seen at a glance.

The principal quadruped noticed in the Chonos Archipelago was the Myopotamus, so valued for its fur. When swimming in salt water the young were often seen sitting upon the mother's back. A small otter was occasionally taken here, while in the forests a number of interesting birds made melody. One little red-breasted songster was an especial favourite, and when Darwin stood still they would often approach so near that he could almost touch them.

This little bird he found was much respected by the natives, its singular cries having to them a peculiar significance: thus one was a good sign; another the reverse, while another still had a third meaning. 
Another bird observed here was termed the barker, on account of the similarity of its note to the bark of a dog. Along the shore were various petrels and gulls. The larger of the latter Darwin observed preying upon small sea-birds, striking them down while on the wing,-a veritable sea-hawk.

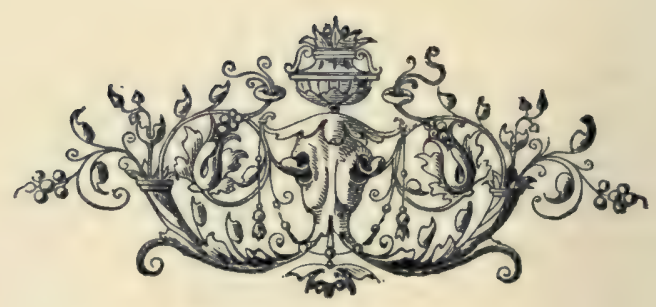




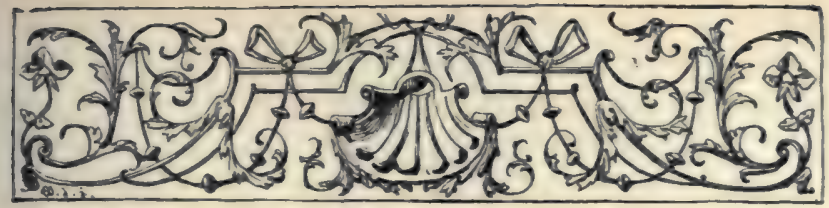

\section{CHAPTER IX.}

IN THE EARTHQUAKE COUNTRY.

At the Bay of San Carlos-Earthquakes-Destruction of Concepcion - At Talcahuana - Tidal Waves - Poverty of the VictimsElevation of the Coast-Darwin's Coolness in Danger-Narrow Escapes.

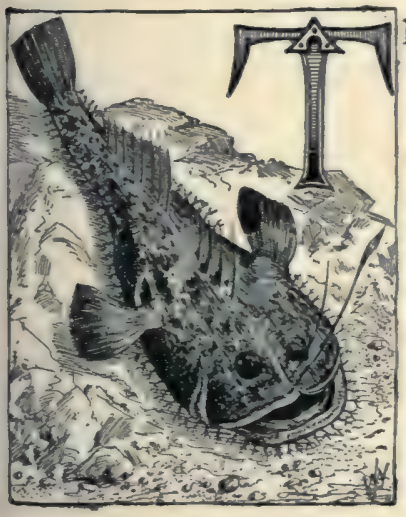

$\mathrm{HE}$ volcanoes, which reared their white crests high in air, were ever an attraction to the young naturalist, and one night, when at San Carlos Bay, an opportunity was offered for observing one in active play. The sentry on guard first noticed it as a star, but it gradually increased until early in the morning, when Darwin with a glass could distinctly see black masses of matter thrown up against the red glaring reflection of the subterranean fires. He learned that Aconcagua was active on this night, and that a wonderful eruption had occurred at Coseguina, two thousand seven hundred miles 
distant. The phenomenon was accompanied by an earthquake, which was felt over an area covering one thousand miles. This same night Vesuvius, Etna, and even Hecla in Iceland burst out with unwonted splendours, - a fact which when known to Darwin was pregnant with suggestions as to the cause of the phenomena.

Our hero was fortunate, if so we may term it, in being a witness to one of the most disastrous of South American earthquakes in many years, or within the memory of the oldest inhabitant. $\mathrm{He}$ was on shore at the time, and, wearied from a long tramp after specimens, was lying in the shade with a companion, when suddenly he experienced a dizzy feeling; the ground rocked, and apparently moved with undulations, which he judged passed from east to west. He sprang to his feet and had no difficulty in standing, though he states that the motion made him giddy, and he describes it as resembling that of the movement of a vessel in a cross ripple. There seemed to be a breeze, the trees swaying and the branches moving to and fro. In the town of Valdivia and upon the sea-shore the scene was different. In the former the inhabitants rushed from the houses into the streets terror stricken, while the wooden buildings creaked and groaned. It was low tide at the time, and the ocean rose almost immediately to high-water mark, then returned again. After the principal shocks smaller ones occurred of lesser strength.

At the time Darwin little dreamed of the destruction this earthquake caused a few miles away, but 


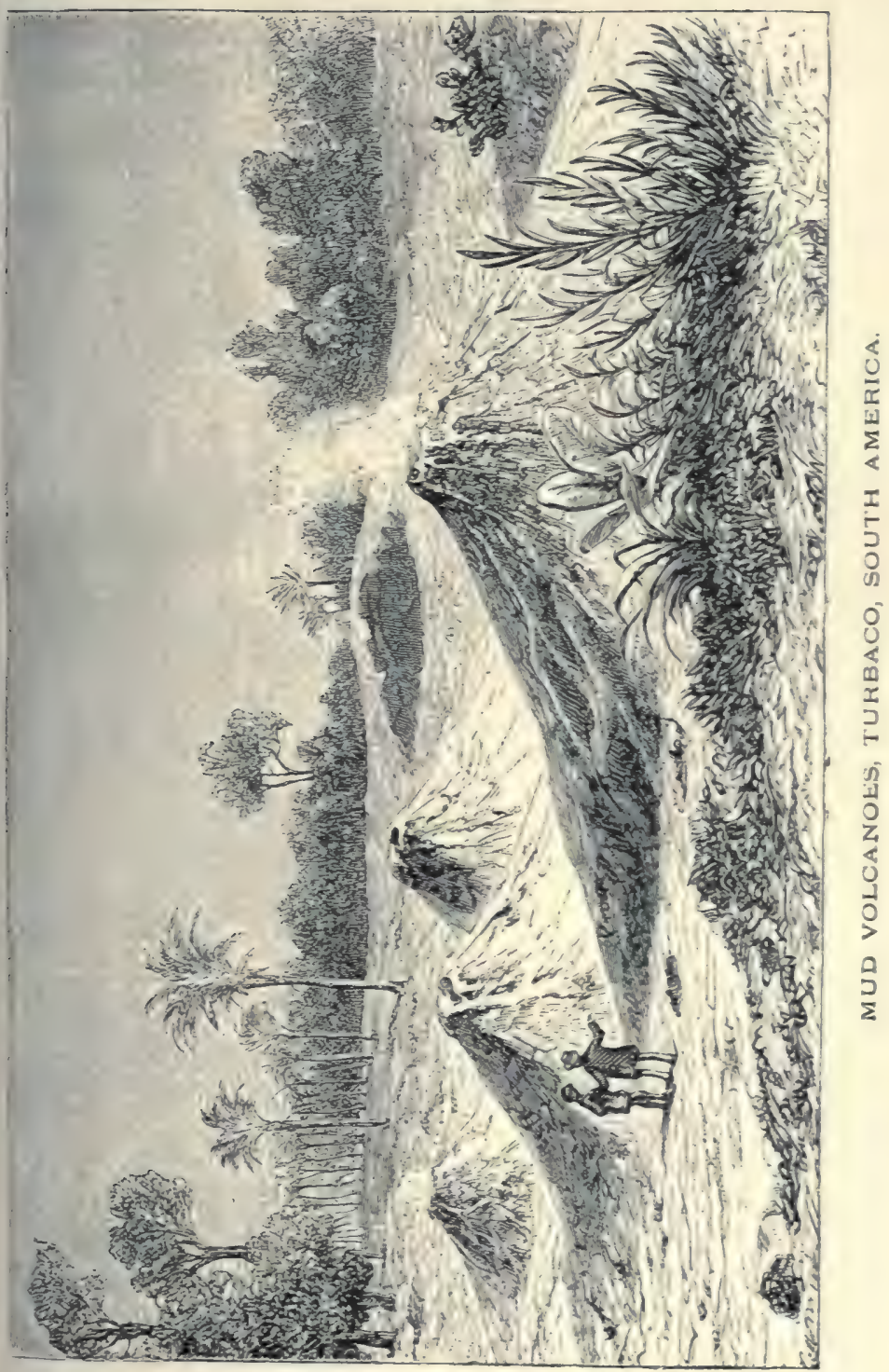



when the Beagle sailed into Concepcion harbour a few days later he landed at the island of Quiriquina, where he was told that the destruction of Concepcion was complete, and that seventy villages were destroyed.

The moment he stepped upon the beach he saw evidences of this, the sands being covered with wreckage of all kinds: furniture, casks, pieces of houses, and objects of a most varied character, which had been brought from the land by the tidal wave of February 2oth. Great rocks were found high above the water, that had a few days before been submerged, and huge fissures crossed the island in various directions, while masses of high land had fallen to the beach; this was on so large a scale that Darwin estimated that the destruction caused a reduction in the size of the island more than equal to the natural wear and tear of a century.

The day following his examination of the island Darwin landed at Talcahuana and rode to the site of Concepcion. What had been a prosperous and substantial city was an unrecognisable ruin - a mass of broken stone thrown this way and that, heaped in inexplicable confusion. The first shock was felt at II:30, identical with the one experienced by the naturalist as he lay in the woods. At the first quiver the people rushed into the streets, as they had done many a time before, and thinking there would be no more, turned to go back when another shock came, and every house crumbled and fell with a crash. The shrieks of dead and dying rent the air, while a white suffocating cloud rose and hung like a 
pall over the dreadful spectacle. Fires added to the horrors of the scene, while thieves, ghoul-like, stole among the ruins, beating their breasts, pretending to cry for mercy, while robbing the dead and dying. The earthquake left not a single building standing in the town. The wreck was complete. The English consul informed Darwin that he was at breakfast when the shock came; he rushed out of the house, reached the middle of the court-yard just in time to escape the side of the house, which thundered down behind him. He had sufficient presence of mind to crawl upon this heap, and thus narrowly escaped the other wall. It was some time before confidence was restored and the people could realise the completeness of the ruin which had come upon them. At the town of Talcahuana, near by, the horrors of a tidal wave were added to those of the earthquake. The people were slowly crawling out of the ruins, gasping for breath and vainly peering through the white dust, when some one uttered cries of fear and pointed to the bay three or four miles away, where a strange greenish wall was seen moving landward. The terrified natives knew not which way to turn. Some rushed for their boats and pulled out to sea, hoping to ride over it; others fell upon their knees in fright, while many more fled to the hills. That in some cases they succeeded in reaching a place of safety shows the deliberation with which the wave came in. It rose twenty feet above the water line, sweeping inland, carrying away houses and every thing in its path. At the head of the bay it broke, the mightiest wave ever seen by mortal 
man, and with a hissing, seething roar rushed upon the town, crushing down the crumbling walls, leveling them like chaff, and in many instances utterly removing all evidence of human habitation. As the wave swept by the fort it caught a cannon weighing four tons and threw it one side. A large schooner was carried six hundred feet from the beach and left amid the ruins.

This wave was followed by two others that carried off a large amount of wreckage. A large ship was lifted high and dry upon the shore, then borne off by a second wave, to be again forced up and carried off by the third wave. Another vessel anchored in thirty-six feet of water was suddenly left aground, while another was whirled around so that her anchorchain became twisted about that of a vessel anchored near by ; these being but a few of the singular features of the catastrophe.

To illustrate the utter destitution of the people, Darwin states that Mr. Rouse, the English consul, took a party under his care for a week, the protection being simply an apple-tree in his garden. At the end of that time it began to rain, and even then the people could find no shelter, so complete had been the ruin.

In his inquiries Darwin learned that the natives laid all the trouble to an old Indian woman, who, two years previous, was supposed to have stopped up the volcano of Antuco in a fit of rage, and as this particular volcano did not burst forth with the others at this time, it was all the more difficult to convince them that they were in the wrong. 
The young naturalist made a careful examination of Concepcion. He found that one set of walls in the city extended south-west by west, another northwest by north, and that the former stood the shock by far the best, showing in his estimation that the undulations came from the north-west, from which direction subterranean noises and rumblings were heard. The fissures in the earth generally extended south-east by north-west, corresponding to some degree with the undulations. The disturbance in the ocean was found to be of a varied nature. With the first shock the water moved up gently, then withdrew to the former position; almost immediately it began to retreat seaward, as if to collect itself, and then came in again with a rush upon the shore. The first movement Darwin judged to be the immediate result of the earthquake affecting differently a fluid and a solid, the levels being disarranged. He considered the permanent elevation of the land perhaps the most remarkable phenomenon, as about Concepcion it was elevated two or three feet. At the island of Santa Maria Captain Fitz-Roy found beds of putrid mussels ten feet above high water, projected there by the earthquake; and as Darwin came across beds of shells at an elevation of a thousand feet, he assumed that it had been effected by a series of small risings. To give a realistic idea of the area of this disturbance, Darwin says :

"It will give a better idea of the scale of these phenomena if (as in the case of the glaciers) we suppose them to have taken place at corresponding distances in Europe: then would the land from the 
North Sea to the Mediterranean have been violently shaken, and at the same instant of time a large tract of the eastern coast of England would have been permanently elevated, together with some outlying islands; a train of volcanoes on the coast of Holland would have burst forth in action, and an eruption taken place at the bottom of the sea, near the northern extremity of Ireland; and, lastly, the ancient vents of Auvergne, Cantal, and Mont d'Or would each have sent lip to the sky a dark column of smoke, and have long remained in fierce action. Two years and three-quarters afterwards, France, from its centre to the English Channel, would have been again desolated by an earthquake, and an island permanently upraised in the Mediterranean."

The naturalist's last experience with the earthquake was in Copiapó, a town of eight thousand inhabitants. He was invited, with Captain Fitz-Roy, to dine with a Mr. Edwards, an English resident, and the dinner was partly over when a shock came, quick, sharp, and decisive. Darwin heard the rumble in advance, and remained quiet, watching the effect. He näively says: "But from the screams of the ladies, the running of the servants, and the rush of several gentlemen to the doorway, I could not distinguish the motion."

This was characteristic of Darwin, and his im. perturbability must have amazed some of the others.

The earthquake was a severe one. Some of the ladies cried with terror, while the gentlemen were badly demoralised. The father of one of the guests had recently experienced the earthquake at Talca- 
huana, and one of the gentlemen had nearly lost his life in 1822 at Valparaiso, jurst escaping a falling roof. That they were easily startled and understood the danger may well be imagined.

Darwin relates a singular incident told by one of these gentlemen. He was playing cards with a party when a German, one of the players, started up saying that he would not sit in a room in an earthquake country with the door closed, as he had nearly lost his life at Copiapo, whereupon he opened the door. As he did so the rumble of the great earthquake was heard, and the entire party sprang through, just in time to escape.

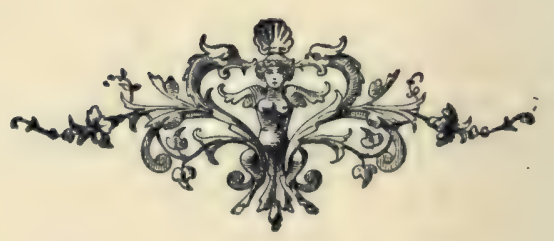




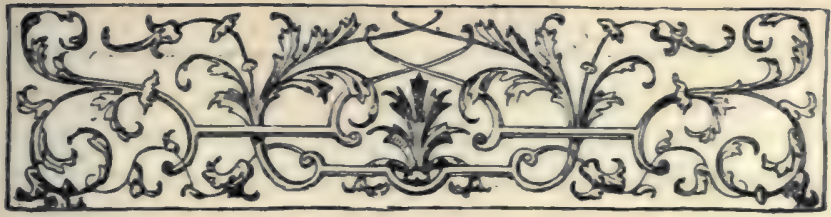

\section{CHAPTER X.}

IN THE RED SNOW COUNTRY.

Valparaiso-The Portillo Pass-Land of the Red Snow-Electrical Conditions-A Swarm of Locusts-Experiments with the Reduvius-A Forest of Stone-Valley of the Copiapó-Ruins at Old Callao-Antiquity of Man.

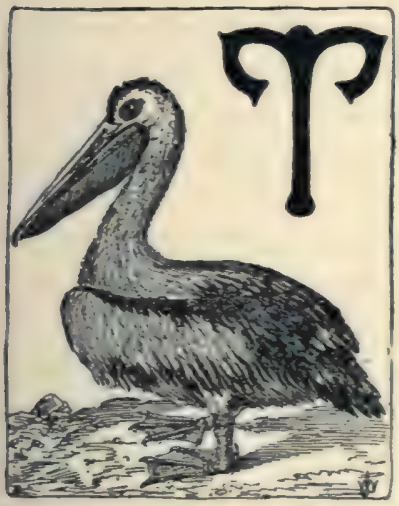

HE Beagle reached Valparaiso on March IIth, from which place Darwin started on a trip across the Cordillera Mountains. The party went by the Portillo, a lofty and dangerous pass which led across the Andes to Mendoza. The scenery was grand in the extreme, and offered a wide and varied field for geological investigation. As they ascended the flora changed, and the gradual replacement of tropical forms by those of an alpine character was observed. The vast mountains spread away on all sides, offering every inducement to the geological hammer of the naturalist; and that a well-defined idea 
of the geological structure of the entire region was obtained by him is evident. He found shells, that formerly lived in the ocean, in beds fourteen thousand feet above the sea. Here was a bed which he surmised was of the age of the chalk cliff of England.

The altitude affected Darwin not a little, especially in walking rapidly, but he entirely forgot it in the delight of collecting fossils, with which the region abounded. The natives called shortness of breath "puna," and suggested various remedies, having singular and original ideas of the cause.

The upper peaks here have been called the land of the red snow, and Darwin was constantly on the lookout for its appearance. One day as he was walking behind the mules he noticed in the track of one a reddish line, and then another, until finally the tint was very distinct, and the famous red snow was discovered-a very common phenomenon in this lofty altitude. At first Darwin thought the pale red hue came from the dust, blown from neighbouring mountains, of red porphyry. The colour was most distinct when the snow was thawing, and if some of the latter was rubbed on a paper a faint red hue was seen, while under the microscope were found groups of minute spheres in colourless cases, each about a thousandth part of an inch in diameter. The red snow was, in reality, a microscopic plant, Protococcus nivalis, and in the Arctic regions especially it often produces wonderful displays.

Crossing the mountains the party descended on the other side into a deep valley between the two ranges, and into the republic of Mendoza. The 
altitude was still over two miles, and vegetation extremely scant. Here the night was passed, in a locality that, from the possibility of a heavy snow, was extremely dangerous, a cave being the only retreat in case of a storm. There was scarcity of fuel, and, owing to the altitude, it required four or five hours to boil potatoes; indeed, Darwin boiled his two days, and found them as hard as at first.

The electrical condition of the atmosphere was very noticeable, as well as its transparency. In referring to this, he says: "The increased brilliancy of the moon and stars at this elevation, owing to the perfect transparency of the atmosphere, was very remarkable. Travellers having observed the difficulty of judging heights and distances amidst lofty mountains, have generally attributed it to the absence of objects of comparison. It appears to me that it is fully as much owing to the transparency of the air confounding objects at different distances, and likewise partly to the novelty of an unusual degree of fatigue arising from a little exertion, habit being thus opposed to the evidence of the senses. I am sure that this extreme clearness of the air gives a peculiar character to the landscape, all objects appearing to be brought nearly into one plane, as in a drawing or panorama. The transparency is, I presume, owing to the equable and high state of atmospheric dryness. This dryness was shown by the manner in which woodwork shrank (as I soon found by the trouble my geological hammer gave me); by articles of food, such as bread and sugar, becoming extremely hard; and by the preservation of the skin 
and parts of the flesh of the beasts which had perished on the road. To the same cause we must attribute the singular facility with which electricity is excited. My flannel waistcoat, when rubbed in the dark, appeared as if it had been washed with phosphorus; every hair on a dog's back crackled; even the linen sheets, and leathern straps of the saddle, when handled, emitted sparks."

The descent was made on the east side of the Cordilleras, where a magnificent view of the pampas was obtained. An immediate difference between the vegetation was apparent, though the soil and climate were materially like that of the country recently passed. The same was true of the fauna, many Patagonian forms being seen, among them the Agouti, Biscacha, three species of armadillo, and ostrich.

As they descended into the valley Darwin had his first experience with the locust. He was near the village of Luxan, when he noticed a large ragged cloud, reddish brown in colour. It was at first supposed to be smoke from a pampas fire, but soon developed into a swarm of locusts. The vast congregation was moving to the north at a rate of fifteen miles an hour. They completely filled the air from a height of twenty feet from the ground to nearly half a mile above it, and made a noise as they flew like the rustling of a mighty wind, or, as Darwin said, of a breeze through the rigging of a ship. Where they were the thickest the sky was wholly obscured. They occasionally alighted upon the ground, so completely covering it that it changed 
before the observer's eye from green to brown. The locusts were a common pest here, and often threatened the crops of the natives, their only salvation being to wage a war of fire against them.

Crossing the Luxan, the village of that name was reached, where the night was spent in repelling the attacks of the reduvius-a black bug that is a most courageous blood-sucker. To test the pugnacity of this creature Darwin placed one upon a table, where, if a finger was pointed at it, the blood-thirsty insect would protrude its sucker and charge at it.

Of the people of Mendoza Darwin quotes the description of Sir F. Head: "They eat their dinners, and it is so very hot they go to sleep-and could they do better?" Darwin adds: "I quite agree with Sir F. Head : the happy doom of the Mendozinos is to eat, sleep, and be idle."

Darwin returned to Chili by the Pass of Uspullata, and here also he made careful geological studies. To show his prescience, upon discovering a layer of tertiary beds resembling some in which he had found fossil trees, he began to search for them here with most satisfactory results, as in the central portion of the range, a mile above the sea, he noticed numbers of snow-white columns projecting from a cliff. Here was a forest of stone, one of the most interesting finds he made, the trees extending in every direction, some silicified, and others coarsely crystallised white calcareous spar. Nearly all were broken off near the ground, and were from four to five feet in circumference. Darwin took sections of them as specimens, and found that they were firs, or 
allied to that family. In the following graphic terms he describes the wondrous changes that resulted in producing this group of trees: "It required little geological practice to interpret the marvellous story which this scene at once unfolded; though, I confess, I was at first so much astonished that I could scarcely believe the plainest evidence. I saw the spot where a cluster of fine trees once waved their branches on the shores of the Atlantic, when that ocean (now driven back seven hundred miles) came to the foot of the Andes. I saw that they had sprung from a volcanic soil which had been raised above the level of the sea, and that subsequently this dry land with its upright trees had been let down into the depths of the ocean. In these depths the formerly dry land was covered by sedimentary beds, and these again by enormous streams of submarine lava-one such mass attaining the thickness of a thousand feet,- - and these deluges of molten stone and aqueous deposits five times alternately had been spread out. The ocean which received such thick masses must have been profoundly deep; but again the subterranean forces exerted themselves, and I now beheld the bed of that ocean forming a chain of mountains more than seven thousand feet in height."

Darwin completed this trip, collecting all the way, and from Valparaiso rode on to Copiapó, where Captain Fitz-Roy proposed to pick him up. It was an excursion to his liking. Travelling on horseback, camping at night, the day spent in collecting and investigating every interesting feature, while at even- 


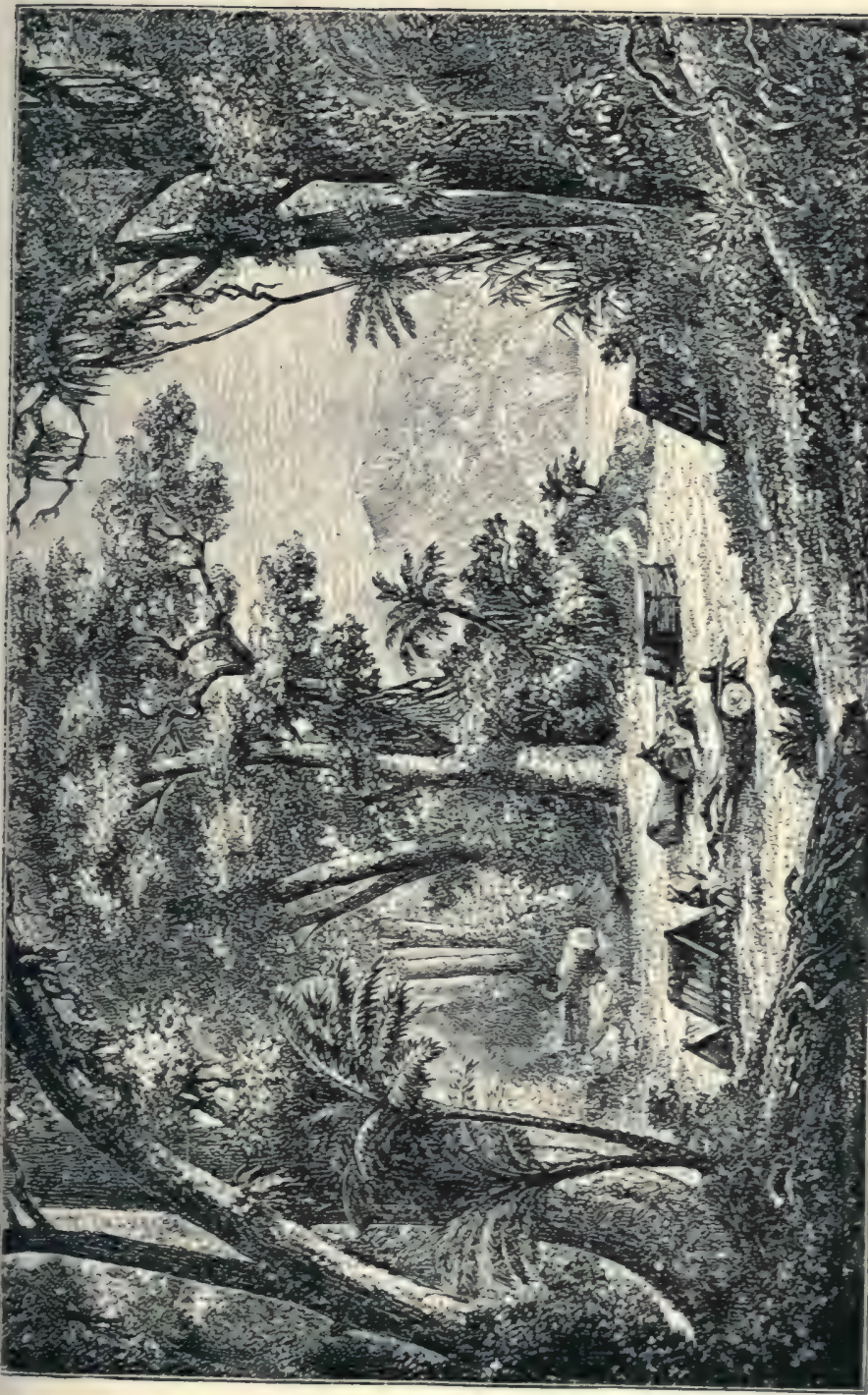

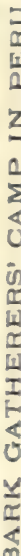



ing the treasures of birds, insects, and fossils were cared for and packed upon the mules.

On these expeditions he was a constant source of wonderment to the natives. Some thought him mad or simple, for who, they argued, would spend time and money in killing birds one could not eat, and picking up the most worthless rocks and leaving the minerals. As he paid well for services, they were content, but he was ever a mystery.

The valley of the Copiapó was a delightful region, and among its interesting features was a hill the natives called "El Bramador," or the roarer, as when persons attempted to climb its sides it emitted an audible warning sound, especially if sand was sent whirling down its sides. From Copiapó Darwin rode to the port where the Beagle was lying, and which at once set sail for Iquique, on the coast of Peru, a small town at the base of a rocky cliff, so barren that even water had to be brought in boats forty miles to supply the inhabitants. Darwin bought a bottle of water here, paying threepence for it. Almost every article had to be imported, yet the town was important for its nitrate of soda works, which the naturalist visited, finding the deposit to consist of a stratum near the surface which had been traced for one hundred and fifty miles, and represented, he assumed, an ancient arm of the ocean, though now elevated thirty-three hundred feet above the sea. From here the Beagle sailed for Callao, where though a stay of six weeks was made, Darwin saw little of the country, as it was not safe to venture into the open on account of 
a war that was impending. Near Lima he examined the burial mounds, or huacas, and the ruins of some ancient Indian villages; but the ruins which most impressed him were those of old Callao, all that remained after a most destructive tidal wave in 1746. His trip to the island of San Lorenzo in Callao Bay was pregnant with results, the field being rich, geologically. In one terrace eighty-five feet up, his quick eye discovered some bits of cotton thread and plaited rushes embedded with shells and other rubbish from the ocean, the former comparing with material he took from the old Peruvian tombs.

This discovery gave him many new ideas concerning the antiquity of man, and he writes in his notebook: "The antiquity of the Indo-human race here, judging by the eighty-five feet rise of the land since the relics were embedded, is the more remarkable, as on the coast of Patagonia, when the land stood about the same number of feet lower, the Macrauchenia was a living beast; but as the Patagonian coast is some way distant from the Cordillera, the rising there may have been slower than here. At Bahia Blanca, the elevation has been only a few feet since the numerous gigantic quadrupeds were there entombed; and, according to the generally received opinion, when these extinct animals were living man did not exist. But the rising of that part of the coast of Patagonia is perhaps noways connected with the Cordillera, but rather with a line of old volcanic rocks in Banda Oriental, so that it may have been infinitely slower than on the shores of Peru. All these speculations, however, must be 
vague; for who will pretend to say that there may not have been several periods of subsidence intercalated between the movements of elevation? for we know that along the whole coast of Patagonia there have certainly been many and long pauses in the upward action of the elevatory forces."

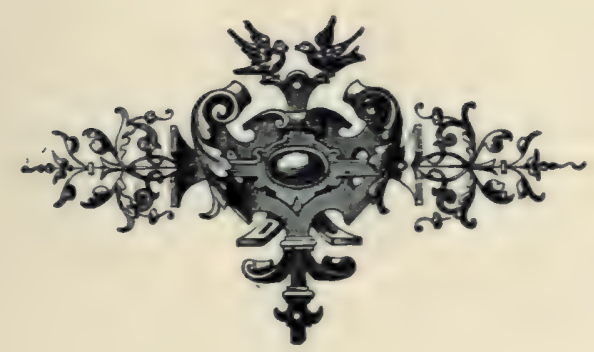




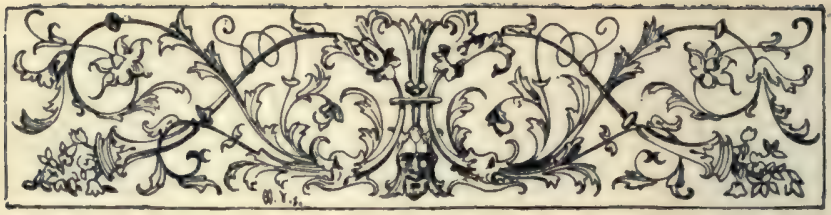

\section{CHAPTER XI.}

AMONG THE OCEAN VOLCANOES.

Galapagos Islands-Number of Craters-Gigantic Tortoises-Land and Marine Lizards-New Marine Forms-Flora-Number of Cryptogamic Plants-Variety of Forms on the Different Islands - Tameness of the Birds.

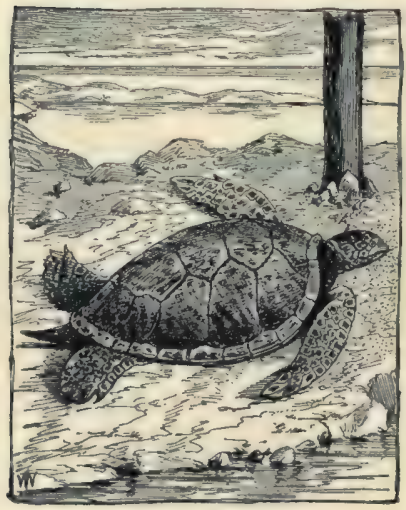

$\mathrm{N}$ the month of September the Beagle crossed the line again, this time on the $\mathrm{Pa}$ cific side, and cast anchor among the islands of the Galapagos Archipelago, that are simply a group of oceanic craters that have forced their way up through the ocean here, and in the course of time attained a somewhat limited fauna and flora.

The islands Darwin found were all volcanic rock, some of the craters which he visited being of vast dimensions, rising three or four thousand feet, their sides pierced with small but ancient orifices from which in the olden time lava had flowed. A some- 


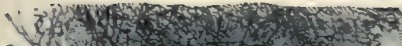

57 .

in $3 x+3$

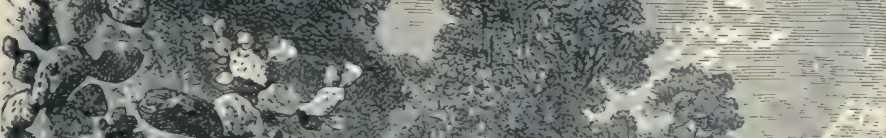

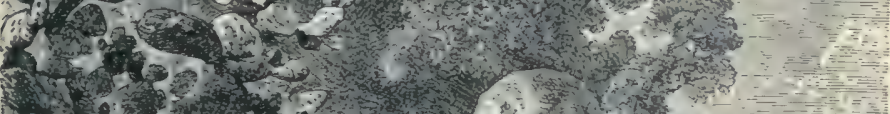
(25)

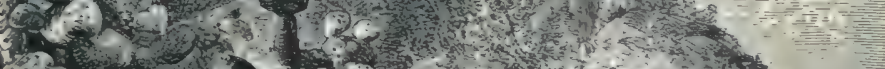

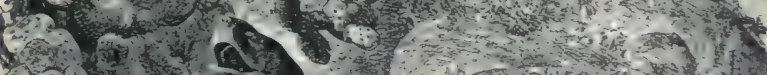
\&.ting

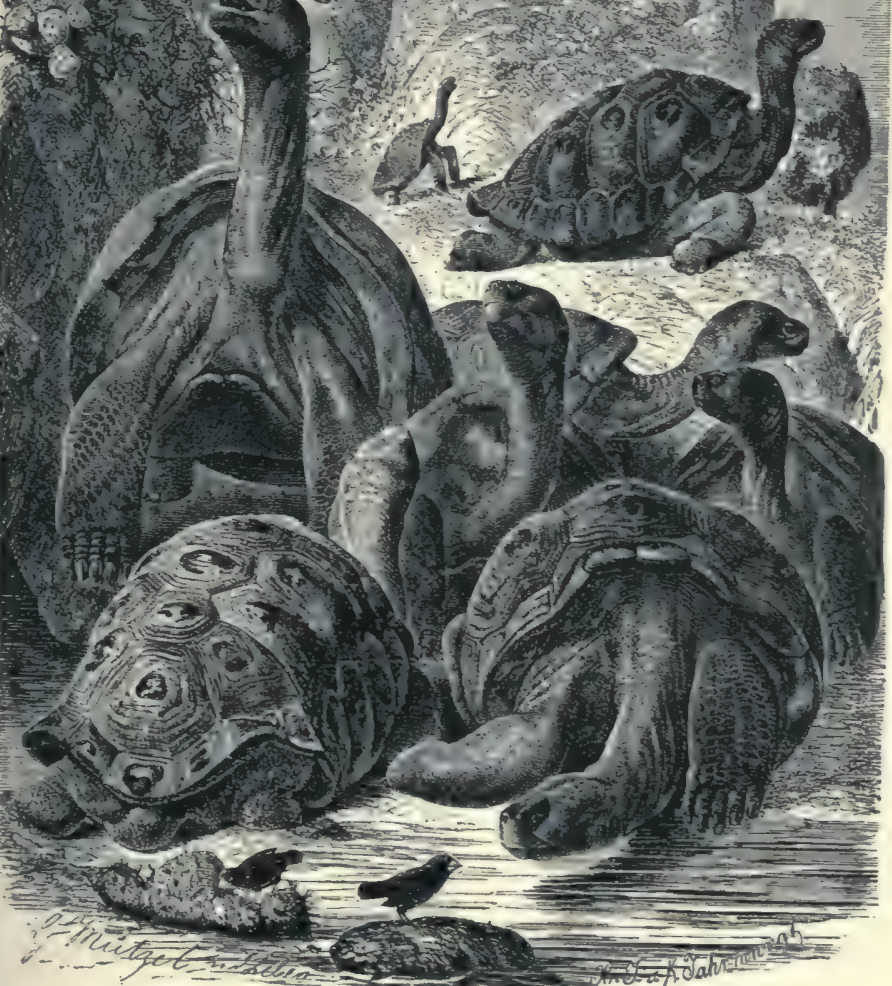

ELEPHANT TORTOISE, GALAPAGOS ISLANDS. 

what careful estimate made by him resulted in showing that in the entire archipelago there were probably not less than two thousand craters. On Chatham Island Darwin camped, surrounded by black truncated cones, which were so numerous that he counted sixty from one spot.

As the name suggests, the islands are called after the large tortoises which abound there, and it was not long before several were found by Darwin, who estimated their weight at two hundred pounds each. One was feeding upon some cactus and hardly noticed him. Some of the tortoises attained to large size, specimens being heard of which required eight men to lift and afforded two hundred pounds of meat alone.

One of the first peculiarities on Chatham Island noticed by the naturalist was the lanes and paths which led in every direction. These were the trails worn by the island giants. The springs to which the animals were obliged to crawl for water were situated in the interior, and here he had an opportunity to watch them wallowing about and covering themselves up in the mud.

To test the speed of the turtles, Darwin watched one for some time, and found that it walked at the rate of one hundred and eighty feet in ten minutes, or 1,080 feet in an hour, or at a rate of four miles per day. To show the strength of the animal, he states that he frequently stood upon the back of one and struck it, whereupon it would move away, generally throwing him off.

Chatham Island and its life had a peculiar interest 
to the naturalist, as he found that the animals were unlike those of other lands, there being even a difference in the forms living upon the various islands. He says: "The archipelago is a little world within itself, or rather a satellite attached to America, whence it has derived a few stray colonists, and has received the general character of its indigenou's productions. Considering the small size of these islands, we feel the more astonished at the number of their aboriginal beings, and at their confined range. Seeing every height crowned with its crater, and the boundaries of most of the lava-streams still distinct, we are led to believe that within a period geologically recent the unbroken ocean was here spread out. Hence, both in space and time, we seem to be brought somewhat near to that great fact-that mystery of mysteries-the first appearance of new beings on this earth."

Darwin was indefatigable in his collecting, and succeeded in finding twenty-six species of birds, all with one exception peculiar to the group.

The most striking objects, next to the tortoises, were the lizards, which, especially the one known to science as Amblyrhynchus - a most singular creature, -were indigenous to the spot. Two species were found, one being a land-loving form, while the other took to the water readily and lived on seaweed. The lizards ranged from four to five feet in length, and weighed about twenty pounds, and were extremely disagreeable creatures in every way. Their tails were flat and used as paddles, and numbers had been seen swimming out in the water in 


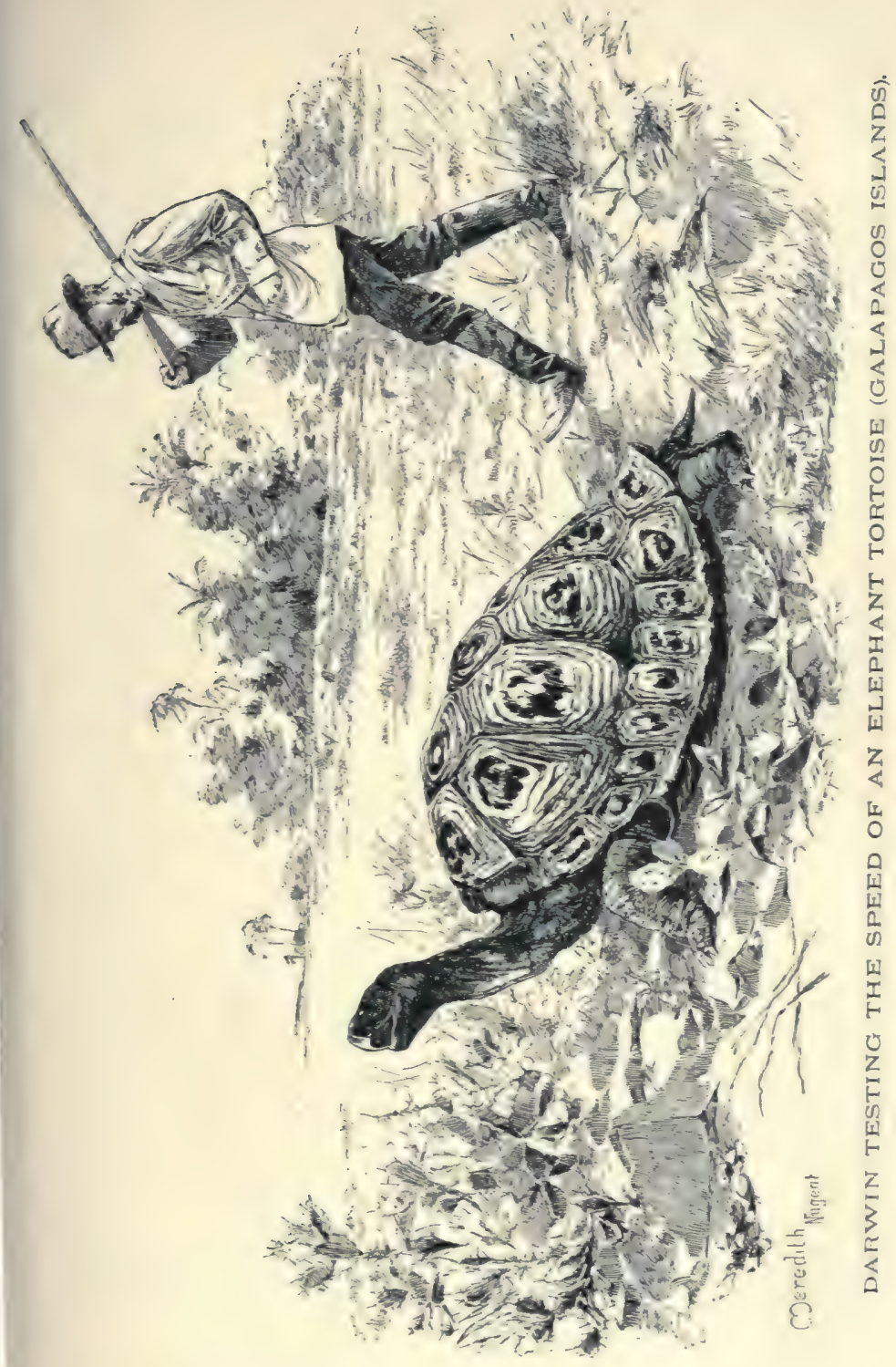



droves or herds. It might be assumed that they lived upon fish, but Darwin opened the stomach of several and found their food to consist of sea-weed, which he found they obtained by diving. When approached, they lazily crawled away, squirting a drop of fluid from the nostrils when suddenly alarmed.

In examining the land species Darwin found that it had a round tail, and feet without webs, and so plentiful were they on James Island that it was difficult to find a place to pitch the tent free from their burrows. Like the turtles, they lived upon the cactus.

The islands proved a rich collecting ground for marine forms, fifteen fish being found here new to science; also sixteen new land-shells. The insects proved a disappointment to Darwin, who remarks that he never saw so poor a country in this respect, though twenty-five species of beetles were collected, among which were several new genera. Of flowering plants he discovered one hundred and eighty-five species, and forty-eight cryptogamic forms, one hundred of the former being new to science and indigenous to the archipelago.

The fact that seemed to have made the most impression upon the naturalist's mind was that the various islands, all in a group by themselves, should possess different inhabitants. "My attention," he says, "was first called to this fact by the vice-governour declaring that the tortoises differed from the different islands, and that he could with certainty tell from which island any one was brought. I did 
not for some time pay sufficient attention to this statement, and I had already partially mingled together the collections from two of the islands. I never dreamed that islands about fifty or sixty miles apart, and most of them in sight of each other, formed of precisely the same rocks, placed under a quite similar climate, rising to a nearly equal height, would have been differently tenanted. It is the fate of most voyagers no sooner to discover what is most interesting in any locality than they are hurried from it ; but I ought, perhaps, to be thankful that I obtained sufficient materials to establish this most remarkable fact in the distribution of organic beings."

Even the birds varied in the different islands, and in an examination of the insects collected by Darwin $\mathrm{Mr}$. Waterhouse states that none were common to any two of the islands. The same was to a certain extent true with the plants. As to the reason for this Darwin says: "The only light which I can throw on this remarkable difference in the inhabitants of the different islands is, that very strong currents of the sea, running in a westerly and westnorth-westerly direction, must separate, as far as transportation by the sea is concerned, the southern islands from the northern ones; and between these northern islands a strong north-west current was observed, which must effectually separate James and Albemarle Islands. As the archipelago is free to a remarkable degree from gales of wind, neither the birds, insects, nor lighter seeds would be blown from island to island. And lastly, the profound depth of 
the ocean between the islands, and their apparently recent (in a geological sense) volcanic origin, render it highly unlikely that they were ever united; and this, probably, is a far more important consideration than any other, with respect to the geographical distribution of their inhabitants. Reviewing the facts here given, one is astonished at the amount of creative force, if such an expression may be used, displayed on these small, barren, and rocky islands, and still more so at its diverse yet analogous action on points so near each other. I have said that the Galapagos Archipelago might be called a satellite attached to America, but it should rather be called a group of satellites, physically similar, organically distinct, yet intimately related to each other, and all related in a marked though much lesser degree, to the great American continent."

One of the most singular, indeed remarkable, features of life here was the tameness of the birds. They did not appear to know what a man was, and could be picked up by the hand or killed with a switch. Darwin frequently caught them in his hat, and actually pushed a hawk from a limb on which it was perched. While lying upon a rock, a mockingbird alighted upon a pitcher by his side, and began to sip the water, allowing him to take the vessel from the ground while upon it. On Charles Island he saw a boy sitting by a well with a bunch of dead birds which he had killed with a switch as they came there to drink.

From these observations the naturalist concluded that "the wildness of birds with regard to man is a 
particular instinct directed against him, and not dependent on any general degree of caution arising from other sources of danger; secondly, that it is not acquired by individual birds in a short time, even when much persecuted, but that in the course of successive generations it becomes hereditary. With domesticated animals we are accustomed to see new mental habits or instincts acquired and rendered hereditary, but with animals in a state of nature it must always be most difficult to discover instances of acquired hereditary knowledge. In regard to the wildness of birds towards man there is no way of accounting for it except as an inherited habit: comparatively few young birds, in any one year, have been injured by man in England, yet almost all, even nestlings, are afraid of him ; many individuals, on the other hand, both at the Galapagos and Falklands, have been pursued and injured by man, but yet have not learned a salutary dread of him. We may infer from these facts what havoc the introduction of any new beast of prey must cause in a country before the instincts of the indigenous inhabitants have become adapted to the stranger's craft or power." 


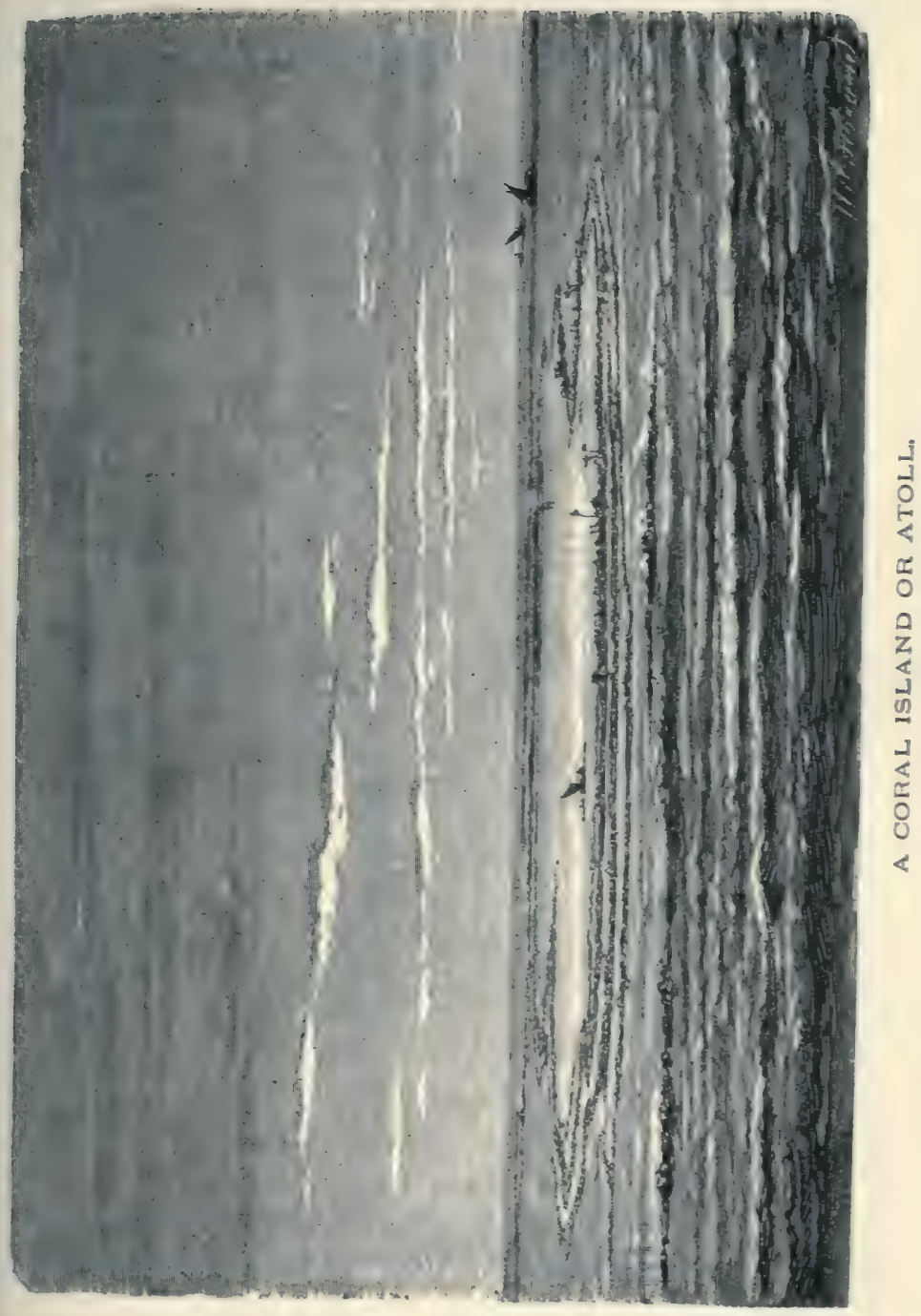





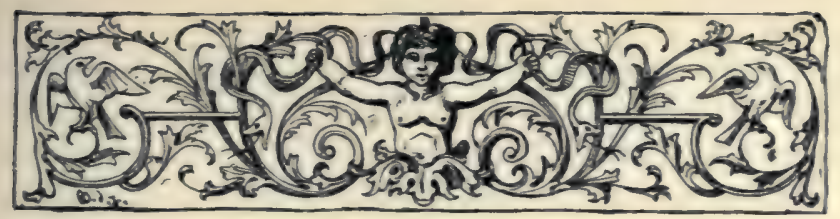

\section{CHAPTER XII.}

IN THE GARDENS OF THE SEA.

Keeling Island-Among the Corals-Towed by a Turtle-Sagacity of the Birgos-Stinging Corals-Coral-Eating Fish-Theories Regarding Reef Structure-Mauritius-Extinction of Animals at St. Helena-Return to England.

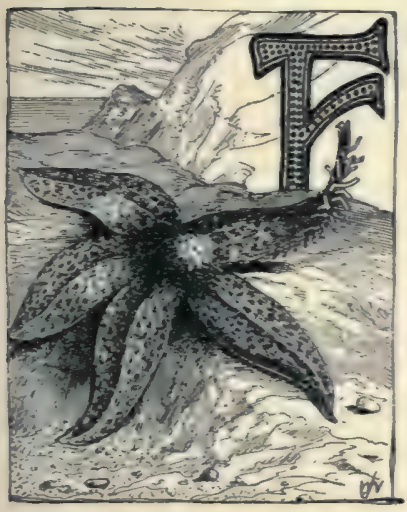

ROM the Galapagos Islands Darwin sailed to Tahiti, thirty-two hundred miles, and then to New Zealand and Australia, reaching Keeling Island in the month of April. Here he found one of the richest fields for operation of the entire voyage, vast beds of growing coral extending in every direction, concealing myriads of forms new to his eyes, and of striking beauty. It was here that he formed some of his theories regarding the nature and origin of coral reefs, that created so much discussion in later years.

Collecting on shore he found disappointing, the 
list of animals and plants being very restricted, but when he turned to the ocean, here indeed was a field in which months might be expended without exhausting its treasures. Hardly a day passed but the young naturalist went out on the great reef and wandered among the coral groves, often combining no little sport with the more æsthetic pleasures of collecting. Thus one day, with Captain Fitz-Roy, he was pulled up a lagoon, which abounded in turtles. A man was stationed in the bow, and as one was sighted asleep on the bottom, he dived over, caught it by the neck, and was borne away at a high rate of speed, much to the amusement of the lookers on. Here, buried in the mud, was found the giant clam, that is so powerful that natives have been caught and held until the shell was dug out and the animal killed.

Keeling, as well as the other islands of the group, was an atoll, a narrow reef, surrounding a shallow lagoon, the former bearing cocoa-nut trees and other plants, the seeds of which had washed ashore. To show the divining mind of Darwin, a green stone rock was found in the conglomerate of one of the outer islands that was so entirely foreign to the surroundings that it was evident that it must have been brought there. Darwin assumed that it must have come in the grasp of a tree root, and his theory was shown to be plausible later, when he learned from Chamisso, the naturalist, that the natives of the Radack Archipelago obtained stones for various purposes by hunting in the roots of trees that washed ashore. 


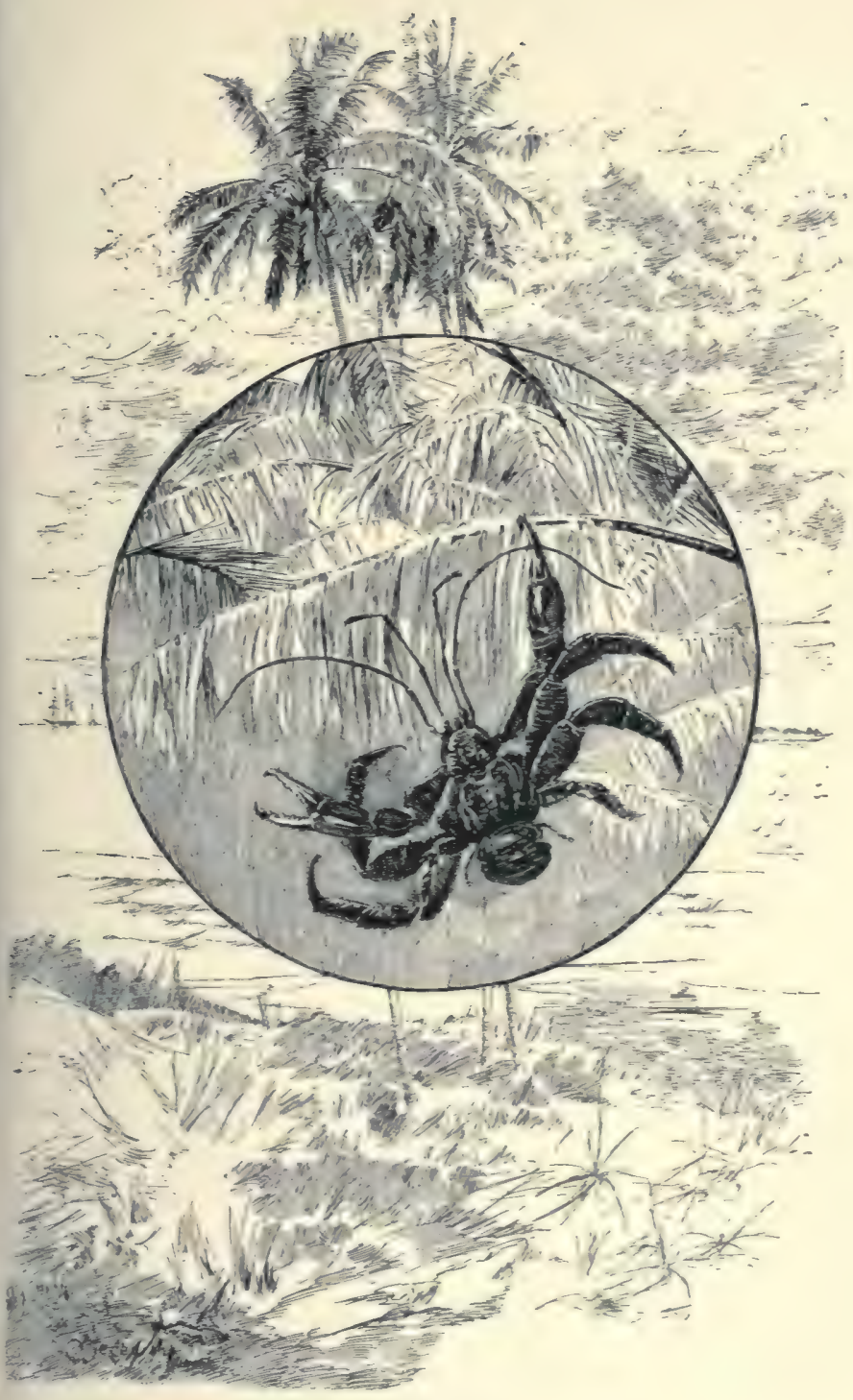

DIRGOS OR COCOA-NUT CRAB. 

In wandering over Keeling Island the naturalist's attention was immediately attracted by the giant land-crab, Birgos, which lived here, feeding upon cocoa-nuts. The crab is, in reality, a close ally of the hermit variety, having, instead of a shell, an abdomen protected by an armor. That such a creature can open a cocoa-nut, which man finds difficult, even with a hatchet, seems incredible, yet it is a very simple matter for the big crustacean. It begins by tearing away the husk, bit by bit, fibre by fibre, and, what is remarkable, always at the end bearing the two eye-holes. When the husk has been removed, the crab hammers away at the holes with its large claw until an opening is made. But then one may ask, how can it obtain the meat? The crab solves this by turning around and inserting its long slender fifth claw into the orifice, which, being armed with pincers, takes out the meat bit by bit. "I think," says Darwin, "this is as curious a case of instinct as ever I heard of, and likewise of adaptation in structure between two objects apparently so remote from each other in the scheme of nature as a crab and a cocoanut tree. The Birgos is diurnal in its habits; but every night it is said to pay a visit to the sea, no doubt for the purpose of moistening its branchiæ. The young are likewise hatched, and live for some time on the coast. These crabs inhabit deep burrows, which they hollow out beneath the roots of trees, and where they accumulate surprising quantities of the picked fibres of the cocoa-nut husk, on which they rest, as in a bed. The Malays sometimes take advantage of this, and collect the fibrous 
mass to use as junk. It has been stated by some authors that the Birgos crawls up the cocoa-nut trees for the purpose of stealing the nuts; I very much doubt the possibility of this. I was told by $\mathrm{Mr}$. Liesk that on these islands the Birgos lives only on the nuts which have fallen to the ground. To show the wonderful strength of the front pair of pincers, I may mention that Captain Moresby confined one in a strong tin box, which had held biscuits, the lid being secured with wire; but the crab turned down the edges and escaped. In turning down the edges it actually punched many small holes quite through the tin!"

Among the discomforts of the reef were the stinging corals, millepora, the big black echini, whose long slender spines projected everywhere above the surface. Among the coral were many fish of resplendant colouring, the parrot-fish, or Scarus, attracting Darwin's attention for the reason that it was a coral eater, the jaws being provided with bony ivory-like teeth well adapted for this purpose. Darwin saw in these coral-eating fish, the holothurians that ate mud and ground it up, the worms and shells, the agents which were at work here in lagoon-making, the white deposit of mud being mainly due to them-a suggestion that has been shown to contain much truth.

The dredging about Keeling Island was suggestive to Darwin of interesting theories regarding the structure of reefs. Thus he found that at a distance of twenty-two hundred yards from the shore the water suddenly deepened, so that a line over a mile in length found no bottom; hence he assumed that the 
atoll was a submerged and lofty mountain, with a summit ten miles across, and sides more precipitous than any peak on land. "Every single atom," he says, "from the least particle to the largest fragment of rock in this great pile, which, however, is small compared with very many other lagoon-islands, bears the stamp of having being subjected to organic arrangement. We feel surprise when travellers tell us of the vast dimensions of the Pyramids and other great ruins, but how utterly insignificant when compared to these mountains of stone, accumulated by the agency of various minute and tender animals! This is a wonder which does not at first strike the eye of the body, but, after reflection, the eye of reason."

Much time and attention was devoted to the study of coral reefs while here, and later was given to the world the results of the naturalist's investigations on the theory of subsidence, which caused no little controversy between Darwin, Semper, and several others.

Darwin found three classes of reefs : atolls, barrier, and fringing reefs, and by a careful system of dredging from the Beagle became convinced that reef coral does not grow in a greater depth than one hundred and eighty feet. From this he assumed that there must have been an original base for all the coral islands at a depth greater than that given. He saw banks and shoals in the ocean miles in length, and in one case fifteen hundred miles long where it would seem impossible for the deposit to have been made by currents or winds. How, then, was the base of the coral island deposited? An elevation of beds of 
sediment he considered impossible, as had this been the case the atolls would have shown lofty pinnacles and rocks elevated above the surface.

From a consideration of this he formulated a theory of subsidence, which he says "at once solves the difficulty." He assumed that these islands were formed in areas of subsidence, that mountains and plateaux were sinking or subsiding, and that the coral was, in brief, forming at a sufficiently rapid rate to keep it at the surface,- - a belief in which Dana, the American naturalist, joined and which was generally accepted. Professor Semper was one of the first to suggest another theory, and the following letter from Darwin, written many years later, may be read with interest in this connection as illustrating the extreme courtesy with which he met those who differed with him, and the evident desire to coöperate with others in bringing out the great truths of nature at whatever cost :

“ October 2, 1879.

"My dear Professor Semper :-I thank you for your extremely kind letter of the Igth and for the proofsheets. I believe that I understand all, excepting one or two sentences where my imperfect knowledge of German has interfered. This is my sole excuse for the mistake which I made in the second edition of my Coral-book. Your account of the Pelew Islands is a fine addition to our knowledge on coral reefs. I have very little to say on the subject; even if I had formerly read your account and seen your maps, but had known nothing of the proofs of recent 
elevation, and of your belief that the islands have not since subsided, I have no doubt that I should have considered them as formed during subsidence. But I should have been much troubled in my mind by the sea not being so deep as it usually is round atolls, and by the reef on one side sloping so gradually beneath the sea; for this latter fact, as far as my memory serves me, is a very unusual and almost unparalleled case. I always foresaw that a bank at the proper depth beneath the surface would give rise to a reef which could not be distinguished from an atoll formed during subsidence. I must still adhere to my opinion that the atolls and barrier-reefs in the middle of the Pacific and Indian Oceans indicate subsidence; but I fully agree with you that such cases as that of the Pelew Islands, if of at all frequent occurrence, would make my general conclusions of very little value. Future observers must decide between us. It will be a strange fact if there has not been subsidence of the bed of the great oceans, and if this has not affected the forms of the coral reefs.

"Yours very sincerely, "Charles Darwin."

Darwin's descriptions of the three classes of coral reefs are too well known to require especial mention, and have been presented by him to the world in a work entitled "Structure and Distribution of Coral Reefs," which if read in connection with Semper's "Animal Life" and other works on corals of to-day, will show the remarkable care and reasoning which 
the young naturalist gave to a subject with which he was then totally unfamiliar.

His investigations at Keeling Island were not confined to corals alone; the natives, their ways and customs, styles of dress, religious ideas, the atmospheric conditions, the currents of the ocean, the flora-in fact, every thing received attention. Darwin was in no sense a specialist; every feature of life, every page in the book of nature, was studied with care and interest, and the amount of material collected and the variety of facts obtained at every place were astonishing.

From these attractive coral islands the Beagle sailed for Mauritius, where Darwin studied every feature of life from the habits of the simplest insect to what he considered the crime of slavery. Stopping at St. Helena he noted the extinction of several animals, and the cause-the denudation of vegetation. In his note-book he writes: "The history of the changes which the elevated plains of Longwood and Deadwood have undergone, is extremely curious. Both plains, it is said, in former times were covered with wood, and were therefore called the Great Wood. So late as the year I 716 there were many trees, but in 1724 the old trees had mostly fallen; and as goats and hogs had been suffered to range about, all the young trees had been killed. It appears also from the official records that the trees were unexpectedly, some years afterwards, succeeded by a wire grass, which spread over the whole surface. The extent of surface, probably covered by wood at a former period, is estimated at no less than two 
thousand acres; at the present day scarcely a single tree can be found there. It is also said that in 1709 there were quantities of dead trees in Sandy Bay; this place is now so utterly desert, that nothing but so well tested an account could have made me believe that they could ever have grown there. The fact that the goats and hogs destroyed all the young trees as they sprang up, and that in the course of time the old ones, which were safe from their attacks, perished from age, seems clearly made out. Goats were introduced in the year 1502 ; eighty-six years afterwards, it is known that they were exceedingly numerous; more than a century afterwards, in I73I, when the evil was complete and irretrievable, an order was issued that all stray animals should be destroyed. It is very interesting thus to find that the arrival of animals at St. Helena in 1501 did not change the whole aspect of the island until a period of two hundred and twenty years had elapsed, for the goats were introduced in 1502 , and in 1724 it is said the old trees had mostly fallen. There can be but little doubt that this great change in the vegetation affected not only the land-shells, causing eight species to become extinct, but likewise a multitude of insects."

From St. Helena the Beagle made Ascencion, a volcanic island, where was found an interesting geological field, and from here bore away for Bahia again, to complete the chronometrical measurement of the world, around which she had passed. On the way up the coast the ship stopped at Pernambuco until about the middle of August. In his note-book 
Darwin says: "I thank God I shall never again visit a slave-country. To this day, if I hear a scream, it recalls with painful vividness my feelings, when, passing a house near Pernambuco, I heard the most pitiable moans, and could not but suspect some poor slave was being tortured." The Cape Verd Islands were next visited, from there sailing to the Azores, and on the $2 \mathrm{~d}$ of October the Beagle cast anchor at Falmouth after an absence of nearly five years.

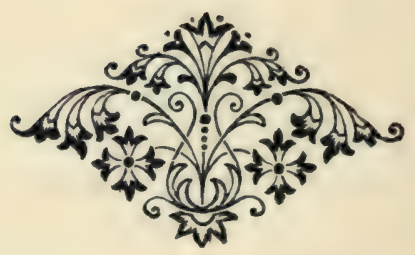




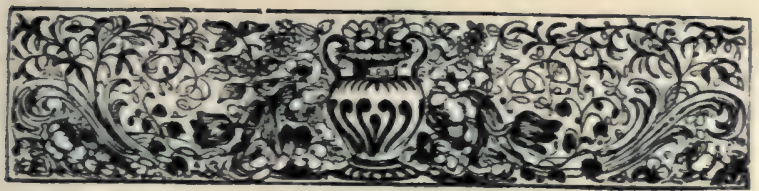

\section{CHAPTER XIII.}

\section{DARWIN THE NATURALIST.}

Ambition of Darwin-Future Work Decided upon-Scientific Friends-Papers Read before Various Societies-Experiments with Earthworms-Marriage of Darwin-Methods of WorkVarious Publications.

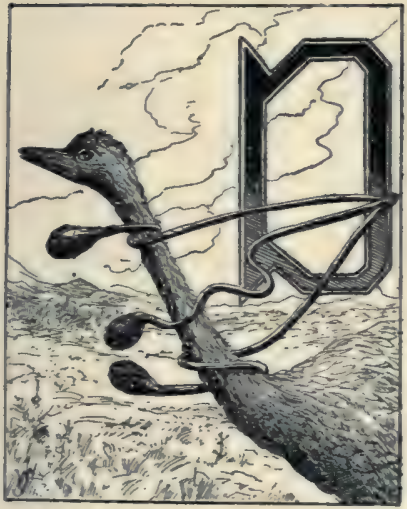

been at the early age of twenty-eight one of the best-equipped naturalists of the age. Having followed him around the world and watched the earnestness with which he carried on his investigations and his indefatigable industry, we may accord him at once a position, not simply as a successful collector,

ARWIN left England a young man without experience, but with a lofty ambition to attain by hard, earnest work a position among the scientists of the day. $\mathrm{He}$ returned after an absence of five years, possessed of information on so great a variety of subjects, that he may be said to have

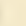


but as a thorough and conscientious worker in almost every branch of science.

There was but one drawback to his pleasure and delight at returning to his native land: this was his failing health. Sea-sickness, which had troubled him from the first, followed him through the entire voyage, and this and the hardships through which he passed undoubtedly undermined his vigorous constitution. His physical condition determined his future career. At the suggestion of Sir Charles Lyell he gave up all thought of professional life, and at once devoted himself to the work of his choice-the study of natural science, and the elaboration of theories and ideas conceived during his life on the Beagle.

Darwin's success had preceded him, and while on the return voyage he received a letter which stated that Sedgwick, the naturalist, had called upon his father and expressed the opinion that his son would take a position among the leading scientific men of the country -an opinion based upon some papers or letters read in 1835 before the Philosophical Society of Cambridge. Darwin had sent some of his fossils to Professor Henslow, so that the attention of palæontologists was also directed to his work.

After a few days spent in the enjoyment of the home-circle-days of delight, after so protracted an absence,- - he returned to Greenwich and began the arduous labour of unpacking and arranging the vast collections he had made. That he was to some extent disappointed in the interest exhibited in the result of his work among eminent men is evident, 
but this was more than compensated by the attention bestowed upon him by Sir Charles Lyell, Professor Owen, Dr. Grant, and others. He soon found that the major part of the work would devolve upon himself, and that it was a labour of years. Professor Owen desired to dissect some of his alcoholic specimens, and Professor Bell, of King's College, expressed an interest in his crustaceans and reptiles ; Professor Broderip offered to undertake the classification of his collection of shells; Gould proposed to arrange the birds, and Jenyns the fish,- -all of which delighted and cheered the young naturalist, whose enthusiasm was so great that it was imparted to those about him.

The College of Physicians and Surgeons offered to take his fossils, describe and classify them, while during a three months' stay at Cambridge Professor Miller aided him in examining the rocks and minerals.

Once having his collections disposed of or in good hands, Darwin began work upon his "Journal of Travels," and in March, 1837, moved up to London, taking apartments in Great Marlborough Street. This period was one of constant activity; he was now well before the scientific world, and apparently upon the threshold of a distinguished career. His scientific friends aided him in every way, especially Sir Charles Lyell, whom Darwin found to be extremely sympathetic, and to take a great interest in all that he did.

He was now proposed as a fellow of the Geographical Society, and a short time after Sir Charles Lyell proposed him as a member of the Royal 
Academy, and so the prophecy of his schoolmate, who was impressed by his devotion to beetle collecting, came true sooner than either expected. $\mathrm{He}$ read several papers before both societies, one especially on the Rhea Americanus attracting attention. Another paper, read before the Geological Society, was on the "Connection of Volcanic Phenomena with the Elevation of Mountain Chains," of which Lyell says: "He opened upon De la Beche, Phillips, and others" - the veterans of the science- " his whole battery of the earthquakes and volcanoes of the Andes."

Darwin was now contemplating the production of the important results of his trip, the zoölogy of the voyage of the Beagle, and, aided by other naturalists, he endeavoured to obtain Government coöperation in the illustration and making of plates. To the petition he secured the names of nearly all the prominent naturalists, including that of the Duke of Somerset, who was then president of the Linnæan Society - also Lord Derby, - and a month later received a Government grant of $\$ 5,000$.

Darwin's geological notes had attracted wide-spread notice, especially the fact that he had brought back many undescribed species, and in 1837 he was tendered the honourable position of secretary of the Geological Society, which he accepted with some little reluctance, owing to the demands upon his time that the duties would entail.

Darwin occasionally found leisure to go into society, and some of the most delightful hours were spent at the house of his friend Professor Henslow, 
where he always met congenial acquaintances. $\mathrm{He}$ also varied his work with readings of the poets, Wordsworth and Coleridge delighting him particularly, while Milton's "Paradise Lost" was, as formerly, a favourite.

In January, 1839, Darwin married his cousin, Emma Wedgwood, daughter of Josiah Wedgwood, and began wedded life at I2 Upper Gower Street, London.

His principal work now was upon coral reefs, upon which he devoted twenty months of hard, unremitting labour. He took an active interest in the societies, read a paper before the Geological Society on the "Erratic Boulders of South America," another on "Earthquakes," and still another on the "Formation by the Agency of Earth-Worms of Mould." The zoölogy of the Beagle was in progress now, and received a portion of his time as well.

Ill-health continued to follow him, and he tells us that scarcely twenty-four hours went over his head without some suffering. Yet this did not deter him from work; on the contrary, it seemed to spur him on to greater exertion. With Sir Charles Lyell he became intimately associated, and no man outside of his own family saw so much of him or knew him so well. Darwin entertained the highest respect for his friend's intelligence, considering him the leading geological thinker of the age. Lyell was remarkable for his sound judgment and caution, exhausting every subject he entered into, and doubtless Darwin imbibed some of this spirit. 
Among the men whose acquaintance he made at this time was Robert Brown, who had similar characterists, showing the greatest care for detail in all his work. Darwin met Sir John Herschel at the Cape of Good Hope, and afterwards often in London. Humboldt, who had delighted him by his works, was a disappointment personally, and he refers to him simply as a good talker. Sydney Smith, Macaulay, Motley, and Grote were other distinguished men whom he met during these years. Comparatively little time was passed from home; his work was the magnet that prevented him from straying far away, and holidays and excursions were rare.

As a working naturalist Darwin was a model of exactness, patience, and perseverance; he rarely lost a moment, and while not a rapid worker, he compensated for this by the attention he gave the subject. His study was adapted for work, his appliances being essentially simple. A dissecting board, with a low, revolving stool, was a principal feature, while a table bore his tools, and various drawers containing the various articles he was likely to use.

Darwin's library was a curiosity, as he considered books simply as a part of his working material, and had not the reverence for them that we find in the bibliophile. They were marked with memoranda, and divided if too large. He often laughed with Sir Charles Lyell over the fact that he had made him bring out an edition of his book in two volumes by informing him that he was obliged to cut the book in halves for use. Pamphlets he cut up, often throwing 
away all the leaves which did not relate to his work. When books were filled with notes he frequently added an index at the end with the number of the pages marked, and thus had a list of the subjects in which he was interested, so at short notice he could command all the material bearing on a certain point in his possession. Fortunately Darwin had ample means, which enabled him to devote his entire time to scientific work without the distraction which would naturally have come from an attempt to make his labour pay a yearly dividend or income. His habits were simple and methodical, and within a short distance of the hum and bustle of the great city of London he carried on his experiments for forty years, happy in the companionship of such men as Huxley, Hooker, Owen, Lubbock, and others, producing results that will place him among the leaders of science as long as time endures.

One of Darwin's experiments will illustrate his method of work, and the consideration and labour which he gave to it. While on a visit to his uncle the latter suggested that the supposed sinking of stones on the surface was really due to the castings of earth-worms. The idea made so strong an impression upon the mind of the naturalist, that he read the paper previously referred to on the subject before the Geological Society. When the farm at Down was secured, in 1842 , he set apart some of the ground for his experiment, which was to cover a part of the field with broken chalk, and note, among other things, the disappearance of the layer through the agency of the worm castings. The plat was covered in De- 
cember, I842, Darwin, waiting twenty-nine years, or until November, 1871, before noting the results; a trench was then dug across the field exposing a series of white dots or nodules; the original deposit of chalk being found on both sides of the trench at a depth of seven inches from the surface. Another portion of this field was spread with cinders in 1842 , and twenty-nine years later the stratum was also found seven inches below the surface, so that Darwin assumed that the mould, exclusive of the turf, had been thrown up at an average rate of .22 inches per year.

These and other experiments resulted in the work, "Formation of Vegetable Mould," published in 1882. All experiments were carried on in the same methodical manner, exactness, conclusiveness, and simplicity being the characteristics of all the work of the great naturalist.

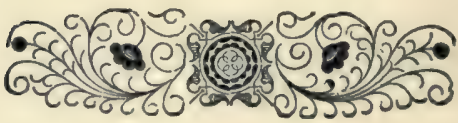




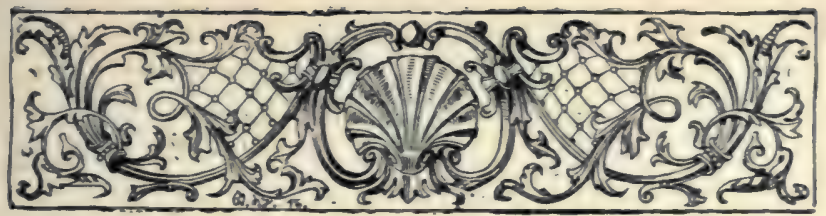

\title{
CHAPTER XIV.
}

\author{
HOME LIFE.
}

Appearance of Darwin-Continued Ill-Health-Daily HabitsChange in Musical and Literary Tastes-Affection for His Children.

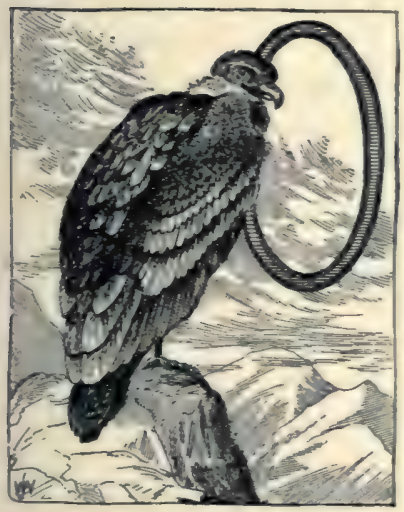

$\mathrm{NE}$ of the most speaking descriptions, or rather impressions, of Darwin, as he appeared late in life in his own home, has been given by Professor Haeckel, of Jena. He writes: "In Darwin's own carriage, which he had thoughtfully sent for my convenience to the railway station, I drove one sunny morning in October through the graceful hilly landscape of Kent, that with the chequered foliage of its woods, with its stretches of purple heath, yellow broom, and evergreen oaks, was arrayed in its fairest autumnal dress. As the carriage drew up in front of Darwin's pleasant country-house, clad in a vesture of 
ivy and embowered in elms, there stepped out to meet me from the shady porch, overgrown with creeping plants, the great naturalist himself, a tall and venerable figure, with the shoulders of an Atlas supporting a world of thoughts, his Jupiter-like forehead highly and broadly arched, as in the case of Goethe, and deeply furrowed by the mental plough of labour ; his kindly mild eyes looking forth under the shadow of prominent brows; his amiable mouth surrounded by a copious silver-white beard. The cordial, prepossessing expression of the whole face, the gentle mild voice, the slow, deliberate utterance, the natural and näive train of ideas which marked his conversation, captivated my whole heart in the first hour of our meeting, just as his great work had formerly, on my first reading it, taken my whole understanding by storm. I fancied a lofty world sage out of Hellenic antiquity-a Socrates or Aristotle stood before me."

While Darwin was an invalid in every sense, and a great sufferer, he did not receive credit for it. His herculean form and a ruddy countenance conveyed the impression of perfect health. In a letter to Dr. Hooker he says: "Every one tells me I look quite blooming and beautiful ; and most think I am shamming, but you have never been one of those."

Generally Darwin wore a large black cloak and slouch hat, when indoors throwing a shawl around his shoulders and drawing over his shoes fur-lined slippers. His habits of work and a desire to economise time made him an early riser, and after a short walk he breakfasted about a quarter of eight, then retiring to his study, considering the hours previous 
to half-past nine the most productive of the day. When the mail arrived, usually about ten o'clock, the letters were read to him, sometimes as he lay stretched upon the sofa, and often an unfinished novel was taken up and perused-a rest which he particularly enjoyed. After this diversion he would retire to his study again, refreshed and ready for work. At mid-day he usually went out for a stroll, either to see some friend in connection with his work or to the green-house where some of his experiments were being conducted. A favourite spot was the "Sand-walk,"-a path about a group of trees of his own planting. It was his custom to walk around this and kick aside a piece of flint from a heap at every turn, thus recording the distance covered. In his walks he almost always had an object. On one occasion he was seen standing like a statue for some time, fixed and immovable. He had stopped to watch a family of squirrels, the young of which urged by intense curiosity left the tree, and notwithstanding the chirping protests of their mother, ran up his legs and back. Early in the afternoon he generally attended to his correspondence, then rested upon the sofa smoking a cigarette, a habit which he contracted in South America among the Gauchos. He was also addicted to snuff-taking, which he deprecated and in a mild way endeavoured to keep in check. He once attempted to break up the habit, and resolved not to indulge in it at home, which one of his friends, a clergyman, called " a most satisfactory arrangement," as the latter kept a box in his study and Darwin often strolled in that direction. 
After four o'clock he would take another walk, then work from half-past four till half-past five. In the evening he played backgammon with his wife, then usually reading some scientific work until the hour for retiring. He enjoyed good music though his ear was not correct, and in this respect and in his literary tastes he considered himself to be deficient, judging from the popular standard. Darwin tells us that he underwent a singular change in this connection as he advanced in years. We have seen that in his youth he was enthusiastically fond of the poets, Milton, Shakespeare, Shelley, Gray, and others, but soon after attaining the age of thirty, his desire for literature of this kind began to cease, until finally he could not endure poetry, while the historical plays of Shakespeare were found "intolerably dull." His taste for a certain class of music and art also failed, while his pleasure in novels, where the imagination was called into play, increased. Darwin considered it a loss of the higher æsthetic tastes, and an atrophy of that portion of the brain upon which they depended, and the fact that he still enjoyed histories, biographies, travels, and various abstruse works puzzled him not a little. In all probability, the five years of active association in so varied a field had blunted his sensibilities for the artificial unless it was of a highly exciting or imaginative character.

One might expect to find in a man whose daily life was a constant fight against suffering, and who worked with a regularity that was almost unparalleled, a break or flaw at times in the evenness of disposition, but Darwin's life was wonderful in its 
patience and example of loving-kindness to all, in its exhibition of gentleness. His married life was perfect in its tender realisation of all that can come from the mingling of well-adapted natures. To his children Darwin was indulgent and kind, tender and sympathetic; he early gained their full love and confidence, and always retained it. That he made them the objects of his scientific investigations is shown by his great work, "The Expression of the Emotions"; yet that he had all the love and affection of the unscientific parent is seen in the following extract from a letter written to a friend: " $\mathrm{He}$ (i.e., the baby) is so charming that I cannot pretend to any modesty. I defy anybody to flatter us on our baby, for I defy anyone to say anything in its praise of which we are not fully conscious. . . . I had not the smallest conception there was so much in a five-months baby. You will perceive by this that I have a fine degree of paternal fervour." His son Francis states that he does not remember ever hearing his father speak an angry word, yet the children never thought of disobeying him. "I well remember," says his son, "one occasion when my father reproved me for a piece of carelessness; and I can still recall the feeling of depression which came over $\mathrm{me}$, and the care which he took to disperse it by speaking to me soon afterwards with especial kindness. He kept up his delightful, affectionate manner towards us all his life. I sometimes wonder that he could do so, with such an undemonstrative race as we are; but I hope he knew how much we delighted in his loving words and manner. How 
often, when a man, I have wished when my father was behind my chair, that he would pass his hand over my hair, as he used to do when I was a boy. He allowed his grown-up children to laugh with and at him, and was, generally speaking, on terms of perfect equality with us."

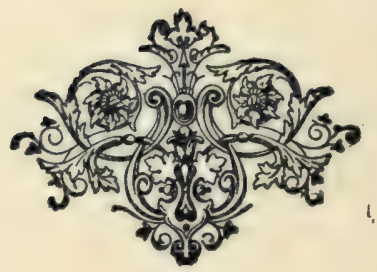




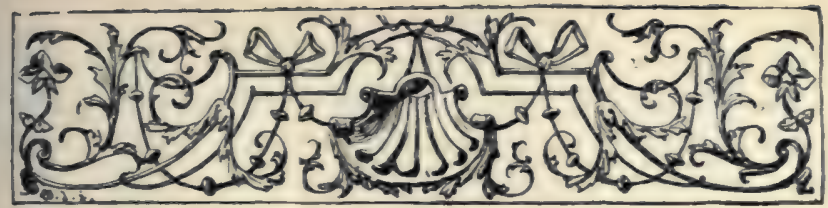

\section{CHAPTER XV.}

\section{THE WORK OF A LIFE.}

Early Papers-Publications by Scientific Societies- "The Formation of Mould"-"The Cirripedia"-The Wallace Incident-Collecting Material for the "Origin of Species"-Success of the Work-Time Spent in Authorship-Religion-Final Work and Death.

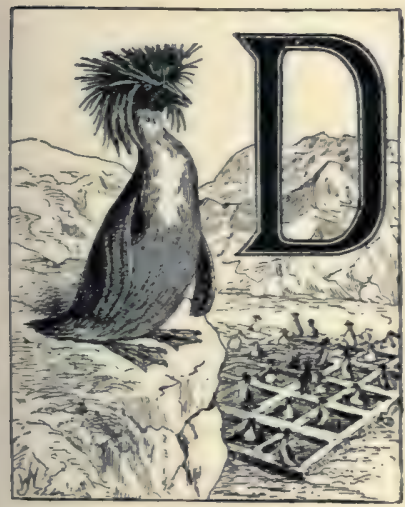

ARWIN'S life-work can only be realised and appreciated by an examination of the papers, monographs, and books which he produced between the years 1835 and 1882 , and with a full understanding of the years of labour entailed in the material and fact-storing process. The voyage of the Beagle was the preparatory time, the season during which he stored his mind with truths bearing upon every possible branch of natural science. He was not simply a biologist; his attention was not given to life alone, but to nature in its broadest sense, and that his re- 
ceptive mind was well equipped to retain the enormous fund of information he acquired, is shown by the elaborate works he has handed down to posterity. We have seen him as a youth reading his paper on the Flustra to the Solons of the Plinian Society; a few years later, when still a young man, we find him a leading and central figure among all the naturalists of Europe, a leader of science in all the term implies.

In 1837 Henslow caused to be published some extracts from his private letters which he considered of public scientific value, and during the same year several important papers appeared in the "Proceedings of the Royal Zoölogical Society of London." In I 838 papers and monographs followed each other rapidly: "The Formation of Mould," " Observations on the Recent Elevation of the Coast of Chili," "A Sketch of the Extinct Mammalia of the Pampas," "Elevation and Subsidence in the Pacific," and "Volcanic Phenomena," produced in this year, all attracted attention in the scientific world. Up to the time of his death Darwin published twenty-three works, each of which is a record of indefatigable research, and an exhaustive treatise on the subject in hand. Besides these he produced eighty-one or eighty-two papers, which were read and published by the various scientific societies of Europe.

The "log-book," which we have followed in the trip around the world, was carefully written during the voyage, and afterwards revised and published in 1839 as a part of Captain Fitz-Roy's report. In I845 it was published separately, proving an imme- 
diate success; and Darwin tells us that "the success of this, my first literary child, always tickles my vanity more than that of any of my other books."

The book had a large sale; the direct and simple method of treatment, so unlike the abstruse and technical scientific works of the day, finding ready acceptance among the great masses of the people. The first edition was soon exhausted ; foreign publishers translated it into French, German, and other languages, and even to-day it commands a large and constant sale. A second edition was brought out, to be followed by others, and it is estimated that fifteen or twenty thousand copies of the book have been sold. This work may be said to have occupied five years in its production.

In 1846 Darwin published his "Geological Observations on South America "; this and two others, including the "Coral Reefs," representing four and a half years of continued and steady labour. Darwin modestly disclaims any merit for them, but they were essentially epoch-making, and in many ways revolutionised existing thought and theory. While in Chili he discovered a new and singular barnacle burrowing in a shell. To understand its affinities necessitated a study of the entire Cirripedes, which resulted in the grand work "Cirripedia," which was published in 1846 . The study and investigations, which resulted in this monograph, required eight years of constant attention, about two of which he considered lost on account of illness, though it is known that he laboured even when ill. The book was, when published, a complete history of these 
forms, both recent and fossil, comprising two thick volumes, and Darwin humorously remarks that he does not doubt that Sir Edward Lytton Bulwer had him in mind when he introduced a Professor Long, a character in one of his novels, as a person who had written two huge volumes on limpets.

This work contained, not only the life-histories of well-known forms, but chronicled many new discoveries. Thus he explained the cementing apparatus, and made the remarkable discovery of minute complementary males.

In all his work, and in every effort of his life, Darwin underestimated his services to science. His modesty was proverbial, and even on subjects of which he was the acknowledged master, he would, with a rare and delightful sense of justice, express the opinion that some one else might have produced greater results with the matter at command. This was so with his master-piece, as he says, in referring to the time he had spent upon it: "I doubt whether the work was worth the consumption of so much time." The great work of our hero's life was his "Origin of Species," and the voyage of the Beagle was the time during which he was insensibly storing up facts which were destined, under his skilful treatment, to make him a leader in the scientific world. That the theory of the great conception entered his thoughts and left an indifferent impression long before he realised its true import, there can be but little doubt. The incidents which focussed his mind on the great idea were the discovery of the huge fossil animals on the South American pampas. $\mathrm{He}$ 
was also impressed with the manner "in which closely allied animals replaced each other in proceeding southwards over the continent; and thirdly, by the South American character of most of the productions of the Galapagos archipelago, and more especially by the manner in which they differ slightly on each island of the group; none of the islands appearing to be very ancient in a geological sense."

The conclusions which he deduced from these facts were that species became modified; in other words, their environment or conditions of life produced changes and modifications. This idea created a profound and lasting impression; as he says, the subject haunted him, and he naturally began to look for other facts bearing upon the same line of thought. Upon his return to England he commenced a systematic collection of data referring to this subject. He read with great care monographs, papers, and reports. He interviewed people of all grades and professions, sent out printed slips with questions and answers, and rapidly accumulated a mass of facts that would have appalled one less enthusiastic. The idea was not yet fully developed; he was still groping in the dark when "Malthus on Population" fell in his way, and was read simply as a recreation. This was in 1838 , fifteen months after he began his collection of facts, and from this source he obtained the idea that in the struggle for existence between various forms, "favourable variations tend to be preserved, and unfavourable ones to be destroyed. The result of this would be the formation of a new species." The idea must have come to him like a sudden 
flash of light that was, indeed, to illumine the scientific world. Yet so cautious was he, so fearful of being prejudiced, that it was not until 1842 that he gave himself the pleasure of even writing out his theory in tangible shape. This copy embraced, he tells us, about thirty-five pages, which was elaborated in 1844 to two hundred and thirty pages. Year after year facts were accumulated and added, and discussions indulged in with his friends, until, in 1856, eighteen years later, Sir Charles Lyell advised him to elaborate his previous work and prepare it for publication. This suggestion was acted upon, and the work was about half completed when a singular incident occurred which, more than anything else, shows the complete and thorough unselfishness of Darwin's nature. He was at work one day when a letter was received from Alfred Russel Wallace, a young Welsh naturalist, who was then travelling in the Malay country. To his amazement, it contained an article embodying the exact theory upon which he had been labouring for so many years in comparative secret. The paper was accompanied by a letter in which the young naturalist requested that Darwin, if he thought the paper deserving, should send it to Sir Charles Lyell for consideration at the Linnæan Society. Never had a man greater temptation, and the result shows the full measure of Darwin's greatness and the breadth and scope of his sense of justice. He sent the article to Sir Charles Lyell, as Wallace had suggested, but Lyell and Sir Joseph Hooker immediately saw the injustice to Darwin which would ensue, and protested against 
the publication of the Wallace article without a statement from Darwin, who, they well knew, had been working on the same subject for years. Darwin was at first not willing to take any action in the matter to protect himself, fearing that he would do an injustice to Wallace; but the difficulty was finally arranged through the mediation of friends, so that the rights of both naturalists, who had almost simultaneously conceived the same idea, were protected, and not for a moment were the relations between them strained. Both were preëminently great, and possessed of natures above the suspicion of jealousy. The result was that the paper of Wallace, accompanied by a letter from Professor Asa Gray, and an abstract of Darwin's work, was published in the transactions of the Linnæan Society, July, 1858 , being, in reality, the first gun in what became one of the greatest discursive scientific warfares of the age.

This publication did not arouse any especial comment, as one might have supposed what was really the birth of modern evolutionism would have done, yet the interest came later on. Sir Charles Lyell and Sir Joseph Hooker now urged Darwin to produce his work, and, after thirteen months and ten days of hard labour, he brought out the now famous work, "The Origin of Species," which immortalised him. Darwin considered this the chief object of his life, and it was a constant delight that the book always had a good sale, though by no means a work for popular reading.

The publishers, supposing that so "stiff" a book 
would have a limited sale, published an edition of twelve hundred and fifty, but no popular novel went off faster. The entire edition was taken up the first day, and, soon after, an edition of three thousand was exhausted. $U_{p}$ to date, about twenty-five thousand copies have been sold in almost every land, the work being translated into many tongues.

We have noticed in this review of Darwin's life that there were, at intervals, incidents which seemed to bring him continually into a brighter light, and the publication of this book was one. It not merely marked an epoch in his life, but, in the language of his friend, Professor Huxley, "the boldness and originality of his speculations, or the profound and universal interest which the book awakened, must be looked upon as marking an era in the progress of science."

The direct result of the publication of this work was to bring the author prominently before the world at large. Darwinism was born, and Darwin's theory was upon every tongue. He was attacked upon all sides, the principal abuse coming from churchmen, who claimed that the theory was an encouragement to infidelity and atheism. It is not my intention to give the details of Darwin's work and ideas here; it is sufficient to say that evolution-which means the coming out, the unfolding of one species from a preceding-did not originate with Darwin, but the latter's theory was his explanation of the methods by which evolution was accomplished. He saw that man, by care in breeding animals, by carefully selecting individuals, could produce strange and singular 
results. He substituted nature for man in the case of wild animals, and saw, in the conditions of life, the climate, the lack or even supply of food, etc., elements which would produce varieties, then species, in long eras of time. So bold a theory could but shake the scientific world to its very centre, and a Darwinian war waged for years. In the end the quiet, unassuming naturalist won the battle, one opponent after another laying down his arms, until, to-day, scientists, almost to a man, accept his grand idea as the embodiment of truth.

About the year I 839 , when collecting facts relating to the preceding work, Darwin was attracted to the cross-fertilisation of flowers by insects, and for many succeeding summers he made careful observations and studies, which, in 1862, resulted in a work entitled "The Fertilisation of Orchids," the actual labour on which, he tells us, cost him ten months of close application. This is one of his most delightful books, leading the reader into what has aptly been termed the fairy-land of science, and telling a wondrous story of the devices of nature to secure perpetuation.

In 1864 Darwin sent an elaborate paper on "Climbing Plants" to the Linnæan Society, which represented the labour of four months, during which time he was often seriously ill. This was published in book form in 1875 , and received a hearty recognition from the scientific world. It contained many original observations, and created active interest in botanical studies. Another work on the "Variation of Animals and Plants under Domestication" 
was begun in 1860 , and published eight years later. The facts collected for this covered many years, while the actual time in the preparation of the volume represented over four years. A second edition, revised and corrected, followed in 1875 . While collecting material for his great work on the "Origin of Species," I 837, Darwin became convinced that man in his present form was the outcome of the evolutionary law, and as a result of his speculations on the question we have the "Descent of Man," published in I87I, to which he gave three years of his life -years of intense application, broken only by the inroads of ill-health. This production added fuel to the flame of criticism, and was the sensation of the day, resulting in an almost endless controversy, which extended from the pulpit to the workshop.

In all these works we see that Darwin had conceived the ideas years before, had been collecting data and working them out through a quarter of a century, and his next publication, the "Expressions of the Emotions of Animals," was the result of similar methods.

In I839 his first child was born, and its expressions and emotions excited not only the intense paternal love that was dominant in his nature, but a desire to observe carefully the gradual development of the human intellect. Almost daily notes were made which will be found in the work given to the world in 1872 . This, too, was an immediate success, 5,227 copies being sold on the day of publication, and the book, like all the others, is still in active demand.

One of the most charming of Darwin's works, to either layman or scientist, is his "Insectivorous 
Plants." Early in 1860 , while on one of his rare vacation trips at Hartfield, he observed the insects which had been caught by the leaves of the little Drosera. The subject so interested and attracted him that he carried some of the plants home, hoping to learn more of them. The idea which he conceived was that possibly the insects were caught for some special purpose. For a period covering sixteen years he studied these and other plants, making a series of experiments wonderful in their detail. The plants were fed with food of various kinds and facts elicited of a most surprising nature, not the least of which was that a plant could secrete, when properly excited, a fluid containing an acid and ferment closely analogous to the digestive fluid of an animal.

In 1876 "The Effect of Cross- and Self-Fertilisation in the Vegetable Kingdom "was published, and in 1880 "The Different Forms of Flowers on Plants of the Same Species." This was followed by a life of Erasmus Darwin, a translation from the German of Krause, in 1879, "The Power of Movement in Plants," and finally, in 188I, he published the work previously referred to, "The Formation of Vegetable Mould through the Action of Worms," that was the outcome of the paper read forty years previous before the Linnæan Society, comprising, as we have seen, experiments which entailed a wait of twenty years before the exact result desired could be determined. This was the last great work of the naturalist.

In Darwin's works there is rarely any reference to religion; this was due to several reasons, one being that he desired not to hurt the feelings of any reader 
by giving publicity to views which might differ from theirs, while another was that he held a man's religious belief should not be paraded in public print. $\mathrm{He}$ has been called an infidel and atheist so often that there is a wide-spread belief to this effect, but nothing could be further from the truth. Darwin was a firm believer in a First Cause. $\mathrm{He}$ was in theory an agnostic, in practice an orthodox Christian of the broadest type. Honourable in the smallest things in life, thoughtful of others, doing as he would be done by, sensitive for others to an extreme that was often injustice to himself, kind, lovable, ready to help the young, charitable, and possessed of extreme modesty, - such was the greatest naturalist of the age, a hero of heroes, a model for all men; and when we remember that for forty years of this life there was not one day without its physical suffering, we can understand the true greatness of his nature.

In February of the year I 882 Darwin was seized with severe heart trouble, which continued, with some intermission, until the Igth of April of this year, when he passed away.

It was the desire of the family to have him rest at Down, but in response to a general request from nearly all the eminent men of the day they consented to his interment in Westminster Abbey, where he lies within a few feet of the tomb of Sir Isaac Newton. The inscription upon the stone is as follows :

Charles Robert Darwin, Born 12 February, I809, Died I9 April, 1882. 


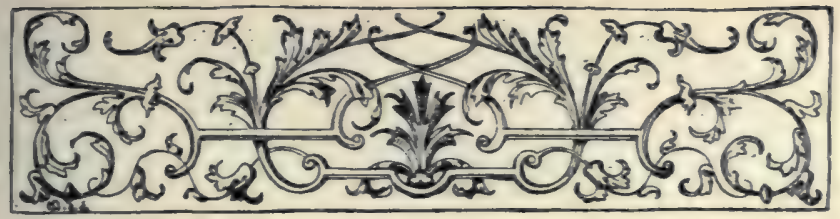

\section{CHAPTER XVI.}

\section{HONOURS OF A LIFETIME.}

Membership in Societies-The Institute of France-Prizes-Medals -Degrees-Portraits-Gifts, etc.

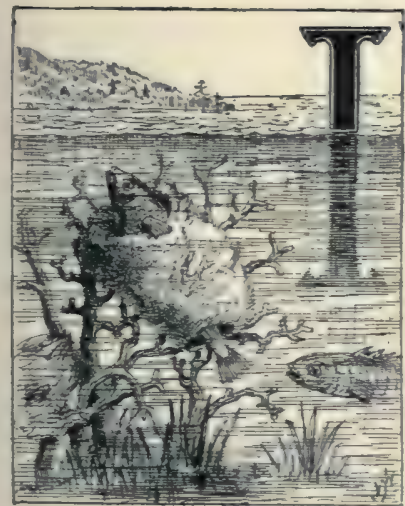

T may be said that Darwin was a member of nearly every scientific society of any prominence. In I831 he was elected a member of the London Zoölogical Society, first being a corresponding member, later becoming a fellow for distinguished services in the cause of science. In I833 he was elected to the Entomological Society, being an original member, and in 1836 he became a member and secretary of the Geological Society. In 1838 he joined the Royal Geographical Society, the following year the Royal Society, the Linnæan in 185 I, and the Ethnological in 1861. Every year new honours poured in upon him in elections to societies or in the form of medals 
or degrees, so that at the end of his ripe and wellrounded life he had received seven or eight degrees, three from Cambridge, and one each from Breslau, Bonn, and Leyden. He was a member of nine London scientific societies, nine in the Provinces, thirteen in America, four in Austria-Hungary, three in Belgium, four in France, ten in Germany, three in Holland, six in Italy, and eight in Portugal, Spain, Sweden, and Switzerland. While he cared little for honours of this kind, they must have impressed him with the fact that his great work was appreciated by the world at large. In 1877 he received the muchtreasured LL.D. of Cambridge. This called to mind the fact that the university had no memorial of Darwin, and forthwith $£ 400$ were subscribed and Darwin asked to sit for his portrait, which he did in $1879, \mathrm{Mr}$. W. Richmond making an excellent likeness, which now hangs in the library of the Philosophical Society at Cambridge. The picture represents him in his doctor's gown, with head facing the observer.

This was followed by a request from the Linnæan Society for a sitting, which was given in I88I, Mr. John Collier being the artist. This shows him standing, in the clothes he habitually wore. Neither of these pictures is perfectly satisfactory to his son Francis Darwin.

In 1878 Darwin was elected corresponding member of the French Institute. A previous attempt had been made to elect him, in 1872 , to the Zoölogical Section, but he received but fifteen votes out of forty-eight, - a fact that Sir Charles Lyell refers to 


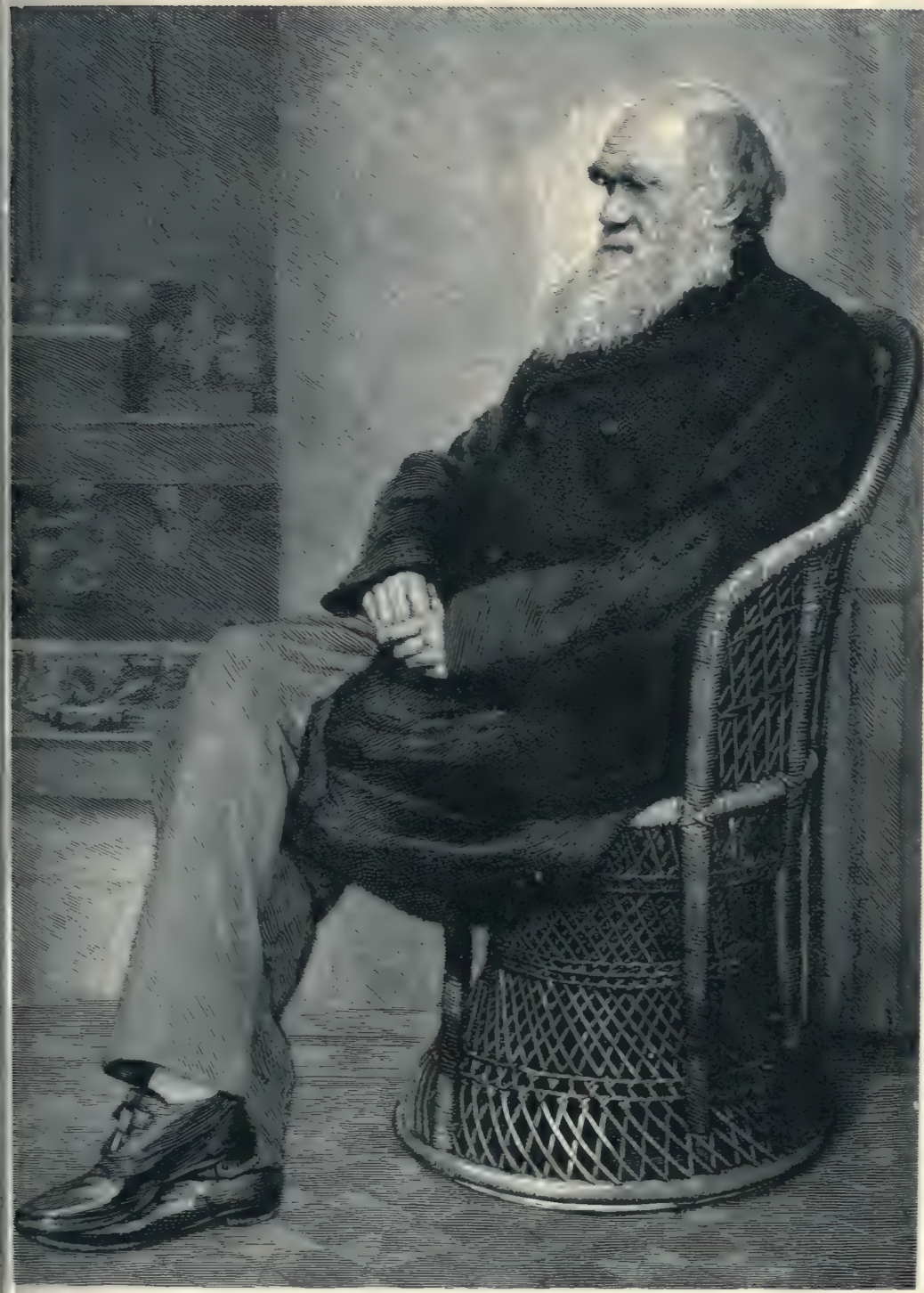

Ch. Darwin 

as " a great scandal." The reason for it will appear amusing to-day, and is as follows, if we may believe an eminent member of the Academy:

"What has closed the doors of the Academy to Mr. Darwin is that the science of those of his books which have made his chief title to fame, the 'Origin of Species,' and still more the 'Descent of Man,' is not science, but a mass of assertions and absolutely gratuitous hypotheses, often evidently fallacious. This kind of publication and these theories are a bad example, which a body that respects itself cannot encourage."

In 1879 he was honoured with the corresponding membership of the Berlin Academy of Sciences, the seconders to the nomination being Helmholtz, Peters, Ewald, Pringsheim, and Virchow.

In 1879 he was presented with the Baly Medal of the Royal College of Physicians, and the same year the Royal Academy of Turin gave him the Bressa Prize for the years $1875-78$, equalling twelve thousand francs, a sum which he in turn presented to the zoölogical station at Naples to enable them to purchase some needed apparatus.

On every birthday he received gifts from his many friends; one which he appreciated highly"being a set of albums from Holland and Germany, presented on his birthday in 1877 . The idea originated in the mind of Herr Emil Rade, of Münster, and the gift was tendered by one hundred and fifty scientific men. The album, which contained the photographs of these gentlemen, was magnificently bound and illuminated in the highest style of art. 
This Darwin considered one of the highest compliments ever paid him.

In 1880 he was much gratified upon receiving an address presented by members of the Council of the Birmingham Philosophical Society.

The following is a partial list of the societies which honoured him and which he honoured by membership :

HONOURS, DEGREES, SOCIETIES, ETC.

Order.-Prussian Order, "Pour le Mérite," 1867.

Office.-County Magistrate, 1857.

Degrees.-Cambridge $\left\{\begin{array}{l}\text { B.A., I83x [1832]. } \\ \text { M.A., I837. } \\ \text { Hon. LL.D., I877. }\end{array}\right.$

Breslau . Hon. Doctor in Medicine and Surgery, 1862.

Bonn . . Hon. Doctor in Medicine and Surgery, 1868.

Leyden - Hon. M.D., 1875.

Societies.-London - Zoölogical. Corresp. Member, I831.

Entomological. 1833. Orig. Member.

Geological. 1836. Wollaston Medal, 1859.

Royal Geographical. 1838.

Royal. 1839. Royal Medal, 1853. Copley Medal, I864.

Linnæan. 1854.

Ethnological. 1861.

Medico-Chirurgical. Hon. Member. 1868.

Baly Medal of the Royal College of Physicians, 1879 .

Royal Society of Edinburgh, r865.

Royal Medical Society of Edinburgh, 1826. Hon. Member, 186r.

Royal Irish Academy. Hon. Member, 1866.

Literary and Philosophical Society of Manchester. Hon. Member, I868.

Watford Nat. Hist. Society. Hon. Member, 1877.

Asiatic Society of Bengal. Hon. Member, I871.

Royal Society of New South Wales. Hon. Member, 1879 . 
Philosophical Institute of Canterbury, New Zealand. Hon. Member, 1863.

New Zealand Institute. Hon. Member, 1872 .

Sociedad Científica Argentina. Hon. Member, 1877 .

Academia Nacional de Ciencias, Argentine Republic. Hon. Member, 1878 .

Sociedad Zoolójica Arjentina. Hon. Member, 1874.

Boston Society of Natural History. Hon. Member, 1873 .

American Academy of Arts and Sciences (Boston). Foreign Hon. Member, 1874 .

California Academy of Sciences. Hon. Member, 1872.

California State Geological Society. Corresp. Member, 1877.

Frankliu Literary Society, Indiana. Hon. Member, I878.

Sociedad de Naturalistas Neo-Granadinos. Hon. Member, I860.

New York Academy of Sciences. Hon. Member, 1879.

Gabinete Portuguez de Leitura em Pernambuco. Corresp. Member, 1879.

Academy of Natural Sciences of Philadelphia. Correspondent, 1860. American Philosophical Society, Philadelphia. Member, I869.

\section{AUSTRIA-HUNGary.}

Imperial Academy of Sciences of Vienna. Foreign Corresponding Member, 1871 ; Hon. Foreign Member, 1875.

Anthropologische Gesellschaft in Wien. Hon. Member, I872.

K. k. Zoölogisch-botanische Gesellschaft in Wien. Member, 1867. Magyar Tudományos Akadémia, Pest, I872.

\section{Belgrum.}

Société Royale des Sciences Médicales et Naturelles de Bruxelles. Hon. Member, 1878 .

Société Royale de Botanique de Belgique. "Membre Associé," $188 \mathrm{r}$.

Académie Royale des Sciences, etc., de Belgique. " Associé de la Classe des Sciences," 1870.

\section{DENMARK.}

Royal Society of Copenhagen. Fellow, 1879. 
France.

Société d'Anthropologie de Paris. Foreign Member, 187r.

Société Entomologique de France. Hon. Member, 1874.

Société Géologique de France (Life Member), I837.

Institut de France. " "Correspondant," Section of Botany, 1878.

Germany.

Royal Prussian Academy of Sciences (Berlin). Corresponding Member, 1863; Fellow, 1878.

Berliner Gesellschaft für Anthropologie, etc. Corresponding Member, IS 77 .

Schlesische Gesellschaft fur Vaterländische Cultur (Breslau). Hon. Member, 1878 .

Cæsarea Leopoldino-Carolina Academia Naturæ Curiosorum (Dresden), 1857 .

Senkenbergische Naturforschende Gesellschaft zu Frankfurt am Main. Corresponding Member, 1873.

Naturforschende Gesellschaft zu Halle. Member, 1879.

Siebenbürgische Verein für Naturwissenschaften (Hermannstadt). Hon. Member, 1877 .

Medicinisch-naturwissenschaftliche Gesellschaft zu Jena, Hon. Member, 1878 .

Royal Bavarian Academy of Literature and Science (Munich). Foreign Member, 1878 .

\section{HOLLAND.}

Koninklijke Natuurkundige Vereeniging in Nederlandsch-Indie (Batavia). Corresponding Member, 1880.

Société Hollandaise des Sciences \& Harlem. Foreign Member, 1877 .

Zeeuwsch Genootschap der Wetenschappen te Middleburg. Foreign Member, 1877 .

\section{ITALY.}

Società Geografica Italiana (Florence), 1870.

Società Italiana di Antropologia e di Etnologia (Florence). Hon. Member, 1872 . 


\section{Honours, Degrees, Societies, Etc.}

Società dei Naturalisti in Modena. Hon. Member, 1875 .

Academia de' Lincei di Roma. Foreign Member, 1875.

La Scuola Italica, Academia Pitagorica, Reale ed Imp. Societa (Rome). "Presidente Onoraria degli Anziant Pitagorici," 1830.

Royal Academy of Turin. 1873. Bressa Prize, 1879.

\section{Portugal.}

Sociedade de Geographia de Lisboa (Lisbon). Corresponding Member, 1877 .

\section{Russia.}

Society of Naturalists of the Imperial Kazan University. Hon. Member, 1875 .

Societas Cæsarea Naturæ Curiosorum (Moscow). Hon. Member, I870.

Imperial Academy of Sciences (St. Petersburg). Corresponding Member, 1867 .

SPAIN.

Institucion Libre de Enseñanza (Madrid). Hon. Professor, 1877.

SWEDEN.

Royal Swedish Acad. of Sciences (Stockholm). Foreign Member 1865.

Royal Society of Sciences (Upsala). Fellow, r860.

\section{SWITZERLAND.}

Société des Sciences Naturelles de Neuchatel. Corresponding Member, 1863. 


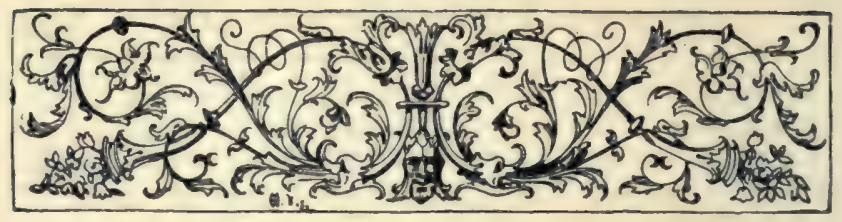

\section{CHAPTER XVII.}

THE DARWIN FAMILY.

The First Known Darwin-The Head of the Family-Natural-History Tastes-Poets, Doctors, and Military Men-Erasmus Darwin-Carlyle's Description of Erasmus-Evidences of Genius.

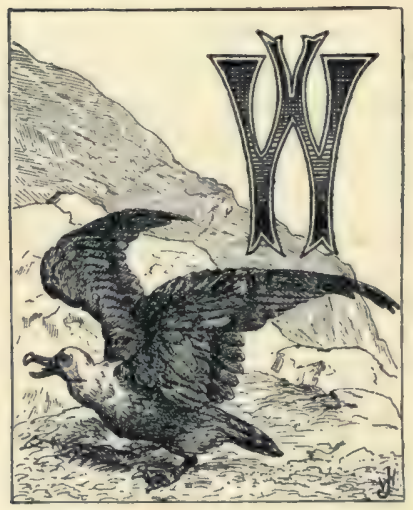

$E$ have seen that Darwin possessed all the elements of greatness; that he was not merely a hero of science in name, but by virtue of his attainments rose to the highest eminence among scientific men, and in the broad field of natural history was the recognised head and leader.

The ancestry of such a man has a peculiar interest, especially after a review of the salient features of his life.

The name has been traced back to the year I 500 , when in Lincolnshire and some other counties it was spelled Derwent, Darwen, and Darwynne. 
The first known ancestor of the present Darwin family was, in I 500 , a resident of the village of Marton, near Gainsborough. His name was William, and the records show that his great-grandson Richard became heir to property in Marton. A clause in the latter's will shows that he "bequeathed the sum of 3s. $4 d$. towards the settynge up of the Queen's Majestie's armes over the quearie(choir) doore in the parishe churche of Marton." Richard's son, named William, was a successful man, and a "gentleman." He retained the ancestral land at Marton, and increased his possessions through marriage, adding an estate at Cleatham, where he settled, the property remaining in the family until the year 1760 . To-day all that remains of the place is a thick-walled cottage, an old fish-pond, some large trees, and a field still called "Darwin Charity," from the fact that it was subject to a charge in favour of the poor of Marton parish. In 16 33 William Darwin was appointed to the post of Yeoman of the Royal Armoury at Greenwich by King James the First. The office was one of honour rather than profit, and he appears to have held it until his death.

The son of this William, called also William, when very young entered the King's service, receiving a commission as "Captain-Lieutenant" in Sir William Pelham's mounted troop. During the troubles of the times, when the royal armies were almost dispersed and driven to Scotland, his estates were seized, but finally returned upon his signing the Solemn League and Covenant and paying a heavy fine, which almost ruined him. Later he became a 
barrister at Lincoln's Inn, and finally married the daughter of Erasmus Earle, from whom Erasmus Darwin the poet received his name. In the course of time he was made Recorder of the city of Lincoln.

In 1655 a son was born to him, also named William, who married a Miss Waring, a lady of good family and heritage, who ultimately inherited from the Lassells the manor and hall of Elston, near Newark-property which is still in the family.

The sons of this William were William and Robert; the latter a lawyer, who finally became heir to the property at Cleatham, there being no male child in his brother's family.

Robert, on the death of his mother, retired from the practice of his profession, and resided at Elston Hall.

In this member of the Darwin family the first evidence of a taste for science is observed. Robert was a member of the Spaulding Club, and Dr. Stukeley, a well-known antiquary of the time, in "An Account of the Almost Entire Sceleton of a Large Animal," etc., published in the "Philosophical Transactions," April and May, I719, says: "Hearing an account from my friend Robert Darwin, Esq., of Lincoln's Inn, a person of curiosity, of a human sceleton impressed in stone, found lately by the rector of Elston," etc.

The eldest son of this Darwin was Robert Waring, who came into the estate of Elston and died a bachelor at the advanced age of ninety-two. He developed a decided taste for poetry, and acquired a local reputation as a rhyme-maker. 
He had a strong liking for botany, and when advanced in years published the results of his studies and observations in a work entitled "Principia Botanica." He was the second of the Darwins to show an inclination for natural history pursuits, and the first to write a scientific work. The book, like those of his illustrious descendant, was a success, passing through several editions.

A brother of Robert Waring, William Alvey Darwin, inherited the Elston homestead, and from him it passed to his granddaughter. His brother John was rector of Elston, while a fourth son was Erasmus Darwin, grandfather of the subject of this sketch.

Erasmus was a tall, striking man, and his stature and love for nature are among the many characteristics he appears to have bequeathed to his grandson. Both had a charm of manner that was irresistible, strong feelings of sympathy, and a love for theorising. Erasmus possessed an inventive faculty, was fond of mechanics, and also had a decided literary and philosophical tendency.

We have seen that Charles Darwin was remarkable for his modesty-the absence of over-appreciation of his own talents, - and it is interesting to see how he resembled his grandfather in this respect. In his "Life of Erasmus Darwin," Charles writes: "Throughout his letters I have been struck with his indifference to fame, and the complete absence of all signs of any over-estimation of his own abilities, or of the success of his works."

The principal works of Erasmus Darwin were: 
"Zoönomia" (I 794-6) and "Botanic Garden," while others were "The Temple of Nature; or, The Origin of Society, a Poem, with Philosophical Notes," and "The Shrine of Nature," a posthumous publication ; "The Loves of the Plants," the second part of "The Botanic Garden," was published anonymously in 1789 , the entire poem appearing in I79I. This production showed more scientific than poetic genius, being especially remarkable for the grandiloquent phraseology and high-sounding words and sentences employed. It was caricatured by Canning in his "Loves of the Triangles." The poem to-day is well deserving a place among the curiosities of literature, and while its decasyllabic rhymed couplets may not be admired, they evidently emanated from no ordinary mind.

An interesting feature in his life is the fact that, to quote his grandson, he undoubtedly " anticipated the views and erroneous grounds of opinions of Lamarck," the fundamental principle of the theory of evolution being traced in his writings. Thus he says " that one and the same kind of living filaments is and has been the cause of all organic life":

"Would it be too bold to imagine that, in the great length of time since the earth began to exist, perhaps millions of ages before the commencement of the history of mankind, - would it be too bold to imagine that all warm-blooded animals have arisen from one living filament, which the great First Cause endued with animality, with the power of acquiring new parts, attended with new propensities, directed by irritations, sensations, volitions, and associations, 
and thus possessing the faculty of continuing to improve by its own inherent activity, and of delivering down these improvements by generation to its posterity, world without end?"

Erasmus Darwin also published a paper on " $\mathrm{Fe}$ male Education in Boarding-Schools." His work, "Zoönomia," was reviewed in 1799 by Thomas Brown, the psychologist, and in 1804 Anna Seward published an account of his life.

The sons of Erasmus inherited their father's intellectual ability-Charles, who was born in 1758 and died when just of age, giving promise of high scientific attainments. He was engaged in dissecting the brain of a child when he recelved the wound which caused his death. He was a writer of verse, and the possessor of a rich collection of natural objects, which he made during extensive travels on the continent. He studied medicine at Edinburgh, and received the first gold medal of the Æsculapian Society for a paper on a medical suoject.

Erasmus, a second son, was also a poet. He was especially interested in coins and statistics, and, when a boy, made a complete and accurate census of the city of Litchfield. Kobert Waring Darwin, born May 30, 1766, inherited his father's taste for the medical profession, and went to the University of Leyden, taking his degree of M.D. in February, 1785. He proved a very successful physician, securing a large practice even in the very beginning of his career.

In 1796 he married Susannah Wedgwood, of Etruria, a woman of rare intelligence and great force 
of character. They lived at the "Crescent," and later at the "Mount," in Shrewsbury, where all but one of their children were born. The old house, a large red-brick building, is now owned by $\mathrm{Mr}$. Spencer Phillips. It stands on the banks of the Severn, commanding a fine view, and supplied with all the acceptable features of an English country home.

Dr. Darwin was something of a botanist, though not in a scientific sense. He was tall, like his son Charles, standing six feet two inches, and very large and fleshy. His mental characteristics were similar to those of his son, having a broad, tender nature, with great sympathy for others. He was a man of remarkable memory, and could recall the names of so many persons and the date of their birth, marriage, and death, that it was absolutely painful to him. He was extremely skilful in prognosticating disease, and was so prophetic in many of his sayings that he was considered a wonder by the ignorant. Dr. Darwin became the father of six childrenMarianne, Caroline, Erasmus Alvey, Susan, Charles, and Catherine, of whom Charles and Erasmus are the best known. The latter studied medicine, taking a degree at Cambridge, but never practised, living a retired and single life in London. Carlyle thus refers to him in his "Reminiscences":

"Erasmus Darwin, a most diverse kind of mortal, came to seek us out very soon ("had heard of Carlyle in Germany, etc.'), and continues ever since to be a quiet house-friend, honestly attached, though his visits latterly have been rarer and rarer, health 
so poor, I so occupied, etc., etc. He had something of original and sarcastically ingenious in him, one of the sincerest, naturally truest, and most modest of men; elder brother of Charles Darwin (the famed Darwin on Species of these days), to whom I rather prefer him for intellect, had not his health quite doomed him to silence and patient idleness. . . . My dear one had a great furor for this honest Darwin always; many a road, to shops and the like, he drove her in his cab (Darwingium Cabbum comparable to Georgium Sidus) in those early days when even the charge of omnibuses was a consideration, and his sparse utterances, sardonic often, were a great amusement to her. 'A perfect gentleman,' she at once discerned him to be, and of sound worth and kindliness in the most unaffected form."

This description failed to convey an idea of the truly lovable nature of Erasmus, and brought out the following letter, which was published by Miss Julia Wedgwood, in the Spectator, September 3, 188 I, giving a true pen picture of the genial and much beloved brother of Charles Darwin the naturalist:

"A portrait from Mr. Carlyle's portfolio, not regretted by any one who loved the original, surely confers sufficient distinction to warrant a few words of notice, when the character it depicts is drawn from mortal gaze. Erasmus, the only brother of Charles Darwin, and the faithful and affectionate old friend of both the Carlyles, has left a circle of mourners who need no tribute from illustrious pen to embalm the memory so dear to their hearts; but a wider circle must have felt some interest excited 
by that tribute, and may receive with a certain attention the record of a unique and indelible impression, even though it be made only on the hearts of those who cannot bequeath it, and with whom, therefore, it must speedily pass away. They remember it with the same distinctness as they remember a creation of genius; it has in like manner enriched and sweetened life, formed a common meeting-point for those who had no other; and, in its strong fragrance of individuality, enforced that respect for the idiosyncrasies of human character, without which moral judgment is always hard and shallow, and often unjust. Carlyle was one to find a peculiar enjoyment in the combination of liveliness and repose which gave his friend's society an influence at once stimulating and soothing, and the warmth of his appreciation was not made known first in its expression; his letters of anxiety nearly thirty years ago, when the frail life which has been prolonged to old age was threatened by serious illness, are still fresh in my memory. The friendship was equally warm with both husband and wife. I remember well a pathetic little remonstrance from her, elicited by an avowal from Erasmus Darwin, that he preferred cats to dogs, which she felt a slur on her little 'Nero'; and the tones in which she said, 'Oh, but you are fond of dogs! you are too kind not to be,' spoke of a long vista of small gracious kindnesses, remembered with a tender gratitude. He was intimate also with a person whose friends, like those of Mr. Carlyle, have not always had cause to congratulate themselves on their place in her gal- 


\section{Erasmus Compared to Charles Lamb. 165}

lery-Harriet Martineau. I have heard him more than once call her a faithful friend, and it always seemed to me a curious tribute to something in the friendship that he alone supplied; but if she had written of him at all, I believe the mention, in its heartiness of appreciation, would have afforded a rare and curious meeting-point with the other 'Reminiscences,' so like and yet so unlike. It is not possible to transfer the impression of a character; we can only suggest it by means of some resemblance; and it is a singular illustration of that irony which checks or directs our sympathies, that in trying to give some notion of the man whom, among those who were not his kindred, Carlyle appears to have most loved, I can say nothing more descriptive than that he seems to me to have had something in common with the man whom Carlyle least appreciated. The society of Erasmus Darwin had, to my mind, much the same charm as the writings of Charles Lamb. There was the same kind of playfulness, the same lightness of touch, the same tenderness, perhaps the same limitations. On another side of his nature, I have often been reminded of him by the quaint, delicate humour, the superficial intolerance, the deep springs of pity, the peculiar mixture of something pathetic with a sort of gay scorn, entirely remote from contempt, which distinguish the Ellesmere of Sir Arthur Helps' earlier dialogues. Perhaps we recall such natures most distinctly, when such a resemblance is all that is left of them. The character is not merged in the creation; and what we lose in the power to communicate our impres- 
sion, we seem to gain in its vividness. Erasmus Darwin has passed away in old age, yet his memory retains something of a youthful fragrance; his influence gave much happiness, of a kind usually associated with youth, to many lives besides the illustrious one whose records justify, though certainly they do not inspire, the wish to place this fading chaplet on his grave."

From such an ancestry, distinguished for its literary and scientific traits, our hero sprang, the bright light in a long line of men and women eminent for their intellectual superiority.

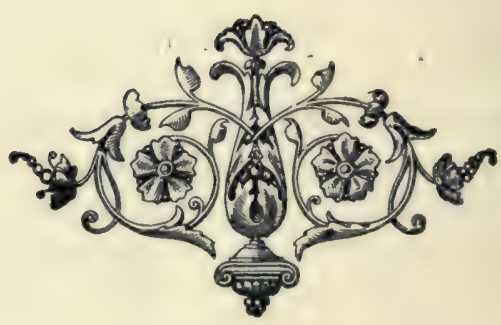




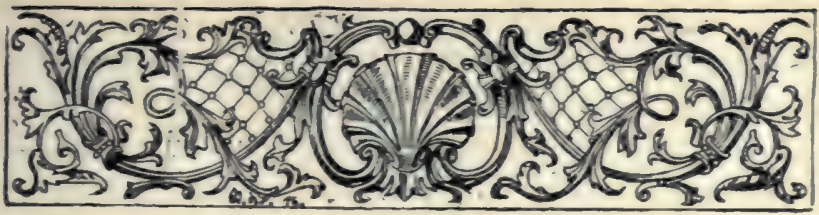

\section{CHAPTER XVIII.}

\section{DARWINISM.}

The Coining of the Word-What it Means-Its Relation to Evolution - "The Survival of the Fittest "- "The Struggle for Existence" -The Descent-Examples of Evolution.

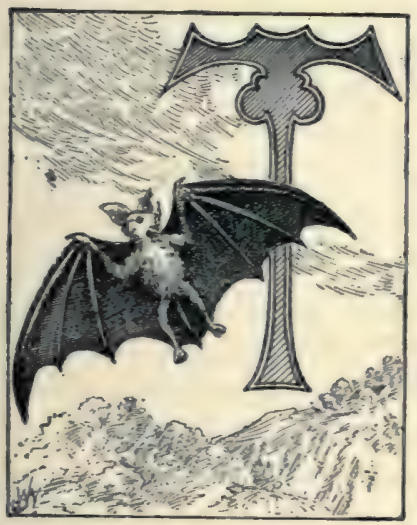

HE scientific labours of Darwin have resulted in the addition of a new w o r d-Darwipism - to the English language,indeed, to that of the world. Literally, Darwinism is Charles Darwin's explanation of the law or method of evolution.

To enable the reader to obtain a clear understanding of what was, in reality, the life-work of the great naturalist, we may refer briefly to the theory and history of evolution. We first hear of the word, or find it, in scientific literature in the early part of the eighteenth century. Previous to this, or in the seventeenth century, the popular idea of the generation of life was that promulgated by Aristotle, his 
theory finding at this time a brilliant advocate in Harvey, who is better known as the discoverer of the circulation of the blood. In the early part of the eighteenth century many naturalists combated Harvey and the theory of his day, and the term evolution was adopted as defining the belief of such naturalists as Bonnet, who claimed that in life nothing really new was created, but that there was a) expansion or growth from the invisible to the visible; an unfolding, as in the growth of a chicken, from the faint germ within the egg. (The term evolution, from the Latin e, out, and volvo, to roll, literally to unfold, implies this. XThe idea opposes direct creation, and evidences of it are found among the very ancient myths. Thus an old Egyptian belief was that all life sprang successively from an egg, and that there had been repeated destructions of the world. The doctrine of Thales was that every thing was originally in a fluid state, and had "progressed" to more substantial forms. Anaxagoras believed and taught that in the beginning every thing was atomic, out of which order and arrangement were brought by some infinite power. In later times (I693) Leibnitz first propounded the belief in inorganic evolution, stating that the world first existed in a fluid state. De Maillet, Wright, Lambert, and Kaul voiced the idea, while Herschel, La Place, and others gave it further and more lucid elaboration. In 1749 Buffon published a natural history, in which he evinced a belief in the transmutation of species.

- Buffon was the naturalist of the day in the time of Louis XV. and Louis XVI.-a period somewhat 


\section{Buffon's Theories.}

famous for the restrictions which were placed upon men, and the denunciations with which new and advanced ideas were received. Thus advanced thinkers found that their theories in many instances, instead of leading them on to fame, but opened the doors of the Bastile.

It is not improbable that Buffon was in accord with the feeling of the time, as while his great discursive work-" Histoire Naturelle," of 1749-1788 -fully outlines the theory of evolution, in which he was a believer, it is done in an ironical, partly satirical manner, so that he could, if attacked, retreat by claiming that it was a satire on the advanced scientific thought of the time.

Buffon refers to the fact that animals and plants are not bound to the limitation of certain fixed species, and expresses the belief that, affected by various influences, species may vary from a fixed standard. Even man might have sprung from some original stock, being merely a divergent form or branch. In other words, Buffon claimed that by simply following out the laws of nature the consequent variation would result in new species; and having arrived at this point, he was ready to believe that from a single unit in the beginning might have descended all the various forms of existing animal and plant life.

It is curious to note that this pioneer evolutionist suddenly corrects himself, and says: "But no; it is certain from revelation that every species was directly created by a separate fiat." We may suspect that this secession from a position so broadly taken 
was forced upon the evolutionist. Perhaps the clergy gave him close and suggestive attention, and he was offered the choice between the Bastile, the Sorbonne, and apology to offended orthodoxy. Be this as it may, Buffon was one of the early delineators of the modern theory of evolution, and despite his peculiar attitude history accords him this recognition.

Following Buffon came Wolff and his works in 1759-1764, in which the idea was still further elaborated. He emphasised the fact that the parts of plants and animals underwent transmutations of structure, so that from seeds, on the one hand, and eggs on the other, came the many complex and diverse organisms. In 1790 Goethe, in his work, "The Metamorphosis of Plants," worked out independently the same result, showing another instance as singular as that of Darwin and Wallace, previously alluded to in these pages. In I795 Geoffroy St. Hilaire, a French naturalist, announced his belief that all animals were the modified forms of previous existing types. Then came Oken (1803), Pander (I8I7), and Von Baer (1819), all adding many facts of value and interest bearing upon the subject. In I 838 Schleiden and Schwann proved that the cellform was alike in animals and plants ; and in 1850-61 Von Mohl and Max Schultze showed that the protoplasm of animals was similar to that of plants.

To go back again, we find that in 1774 Lord Monboddo announced that the descent of man from an ape was a possibility. In I795 Dr. Erasmus Darwin, grandfather of our hero, published his "Zoönomia," which contained the germ of the theory 
of evolution. He accepted the idea of Buffon, that species were the results of modifications in the slow generation of life, and added that these modifications arose from the actions and requirements of the animals themselves.

This work produced little or no immediate effect, but it undoubtedly influenced many naturalists who followed, including Lamarck, Lyell, Spencer, and, chief of all, the grandson of Erasmus, Charles Darwin, who in the present age stood as the leading apostle of the theory.

In I 80I Lamarck began his series of crusades against the opponents of evolution. Bold, frank, imperious in his mental sovereignty, he had neither the caution of Buffon nor the deference to the Church and public opinion shown by many of his predecessors. What he thought, he wrote, and what he believed in, he announced to the world, fortifying it with proofs from the abundant resources of his mind, stored with the results of a lifetime of research. Of this giant of science Charles Darwin writes: " $\mathrm{He}$ first did the eminent service of arousing attention to the probability of all change, in the organic as well as in the inorganic world, being the result of law and not of miraculous interposition. Lamarck seems to have been chiefly led to his conclusion on the gradual change of species by the difficulty of distinguishing species and varieties, by the almost perfect gradation of forms in certain groups, and by the analogy of domestic productions. With respect to the means of modification, he attributed something to the direct action of the physical conditions of 
life, something to the crossing of already existing forms, and much to use and disuse - that is, to the effects of habit. To this latter agency he seems to attribute all the beautiful adaptations in nature(such as the long neck of the giraffe for browsing on the branches of trees." Lamarck's theory may be expressed briefly: he avowed that all life, including man, had descended by various modifications from one or more primordial forms, and he believed that the various animals had to a greater or less extent been developed by their habits, their efforts to live, and the conditions which surrounded them.

No writer of the day produced the effect of Lamarck. His "Philosophie Zoölogique" influenced the scientific sentiment of all Europe, and the writings of the men of his time and ever since are tinctured with his philosophy.

In the year I 844 renewed interest was created in the subject by the appearance of a work entitled "Vestiges of Creation," supposed to be written by Robert Chambers. Humboldt now affirmed his belief that species are not immutable, and following came Owen, Asa Gray, Herbert Spencer, Youmans, and many more who had thought upon evolution and believed in it in some form.

It will be seen, then, that evolution as a theory is not of recent origin, but was discussed pro and con until the time described in a previous chapter, when Charles Darwin and Alfred Wallace came out simultaneously with their views on the subject; then Darwinism was born, and in it we find our hero's explanation of the method of evolution. 
This leads us to a review of Darwin's theories, which were, as we have seen, the result of years of thought and research, and which have conquered or won nearly the entire scientific world of thought. We have seen that his observations in South America and elsewhere created the germ which itself, by a series of evolutions, assumed the well-defined and philosophical form of the theory of Darwin of to-day.

The evolutionists taught that the various species were the simple result of an unfolding, a development, a growth with constant occurring change; but they did not tell us how the change was created. Darwin did, and this is how he accomplished it. Probably every reader of this work has, at some time in his life, been the owner of pets-rabbits, dogs, or cats, and has from experience obtained certain welldefined ideas of the results which can be produced by careful breeding and intelligent selection. It is known that the race-horse is one result of carefully selecting horses generation after generation which have shown similar characteristics. Trotters with a record are mated; so with running horses, those adapted for the carriage, or the plough, and the result is existing varieties of the domestic horse. Man began with the original blue-rock pigeon, and has produced all the famous varieties-the tumblers, pouters, carriers, and others, this being accomplished by careful and intelligent selection. In dogs, the original companion of early man was a wild animal allied to the wolf. To produce the many varieties (which some naturalists call species), 
man has acted with careful discrimination. A dog with especially long hair has been selected and bred with another showing like characteristics. Among the progeny of these all the long-haired dogs were selected and as carefully mated, until finally a welldefined long-haired variety was the result, so that in looking at it the observer, familiar with none but the wild, wolf-like dogs, would have said: "Yes, it seems to be a dog, but it differs from the others; it is a new variety of dog."

So the original jungle fowl, under the supervision of the breeder, has been made to produce the many curious varieties of fowl ; and so we could go on indefinitely, citing cases where man has shown his power of producing certain singular results in the shape and form of living beings. The greyhound, with its enormous chest, its narrow, pointed nose, its slender legs, every feature denoting speed, is a marked contrast to the Dachhound, with its short bow-legs and ungainly form; yet each can be traced back to a common stock. Man has produced this marvellous transformation by making a study of dogs, selecting those with certain peculiarities and mating them, which has resulted in a form which, when compared to the original, is called a variety.

That similar conditions also hold in the human race, and could be carried out indefinitely, is shown by a well-known instance cited by Professor Huxley. He says: "Gratio Kelleia, a Maltese with six fingers and six toes, married when he was twenty-two years of age, and, as I suppose there were no six-fingered ladies in Malta, he married an ordinary five-fingered 
person. The result of that marriage was four children; the first, who was christened Salvator, had six fingers and six toes, like his father; the second was George, who had five fingers and toes, but one of them was deformed, showing a tendency to variation; the third was André; he had five fingers and five toes, quite perfect; the fourth was a girl, Marie; she had five fingers and five toes, but her thumbs were deformed, showing a tendency towards the sixth.

"These children grew up, and when they came to adult years, they all married, and of course it happened that they all married five-fingered and fivetoed persons. Now let us see what were the results. Salvator had four children; they were two boys, a girl, and another boy: the first two boys and the girl were six-fingered and six-toed like their grandfather; the fourth boy had only five fingers and five toes. George had only four children; they were two girls with six fingers and five toes on the right side, and five fingers and five toes on the left side, so that she was half and half. The last, a boy, had five fingers and five toes. The third, André, you will recollect, was perfectly well formed, and he had many children whose hands and feet were all regularly developed. Marie, the last, who, of course, married a man who had only five fingers, had four children: the first, a boy, was born with six toes, but the other three were normal."

The appearance of the sixth finger in this man illustrates the fact that all life, from the lowest forms to man inclusive, is liable to variation; some peculi- 
arity may appear. We may call it a monstrosity, a freak, or an accident, but if the conditions are normal, the chances are that it will be perpetuated to some extent, while if they are extremely favourable it may be transmitted indefinitely. There is no controverting this; it is a simple fact understood by everyone. Darwin recognised it, and accumulated a vast amount of testimony showing its possibilities in all ranks of life; and seeing that varieties could be produced in domestic animals and plants, he laid down the theory that almost the same selection and discrimination are taking place in nature; the tendency being to perpetuate certain features, which in time become so prominent that they assume the dignity of varieties. As an illustration I cite an instance of my own observation. We have seen that man produces the trotter by weeding out those which vary from this type; now let us glance at nature and note how animals may gradually assume a like appearance by selection. Several years ago I was drifting along on the edge of the Sargasso Sea, when my attention was attracted to the remarkable fauna of the weed. Here was the curious fish, Antennarius, lying prone upon the weed near its nest-a ball of sargassum. Had I not been familiar with the little creature it would have escaped my notice, as its colouring was identical with that of its surroundings: not a fanciful resemblance but one in fact; the very tints and hues being imitated as if the fronds and leaves of the sargassum had been photographed on the sides of this curious mimic. The crabs all partook of the same protective favour, 


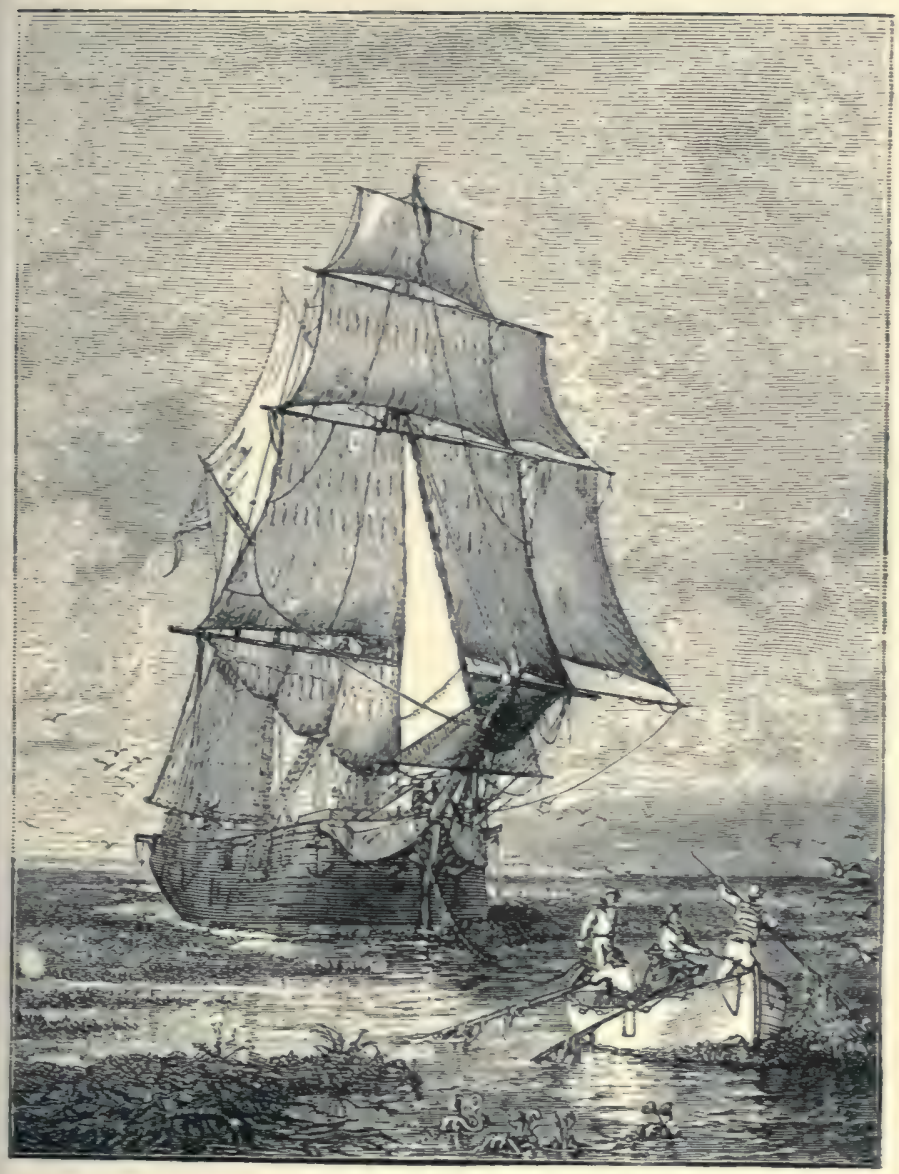

COLLECTING IN THE SARGASSO SEA. 

and could only be detected by the most careful observation. The worms were of deep tints of olive and yellow, and so on all through this floating city; the same brush, the same colours, the same artist had been employed, each and every living creature being in colour a mimic of the vast weed bed that constituted their floating home.

The fact that I could not find the crabs and other forms without difficulty, though they were floating upon the surface, often in full view, suggested at once that here nature had provided a wondrous protection, and that the inhabitants of the sargassum were safe from their many enemies in their mimicry.

But how was this condition obtained? The crabs, worms, and fishes of this mass of weed were not always thus protected. We know that long ago or in the past they lived elsewhere, and came as immigrants to the floating home, and were then in striking contrast to it. How then could this great change have been produced? Assuming that the crabs and other forms have recently taken up their residence here, we notice that they are not all alike in colour; there is a disposition to vary. Some are darker than others, some lighter, some are spotted, and a few perhaps resemble the colour of the weed. The latter are accidents, freaks, just as in the case of the dogs where perhaps one or two showed an abnormal development of hair. In this instance man did the selecting; but in the case of the crabs it is a gull, or many that are soaring over the weed in search of food. The freaks or varieties which happen to resemble the weed, being inconspicuous, are not 12 
noticed, while the others, presenting a marked contrast are seen, and devoured. This continues year in and year out ; crabs which are conspicuous are eaten, and the tendency is to weed them out, leaving those which bear a resemblance to their surroundings. These breed and produce others; some of which mimic the weed, and some do not. The latter are soon picked up by their enemies, the others being preserved to perpetuate their kind through the agency of the bird that acts in the place of the intelligent breeder.

We see, then, as Darwin believed, that nature is doing almost exactly what man does in producing varieties.

In the life of these animals there is a strife or struggle for existence with the conditions that work against them. Some survive, and only those which are the fittest to carry on the work of perpetuation. The struggle, the silent combats or tendencies to survive, are what Darwin calls natural selection, while Herbert Spencer styles it the survival of the fittest -terms which have become bywords in their familiarity to the readers of the present century.

An instance in plant life may still further illustrate the point that accident, a peculiarity, a series of conditions-climate, food, etc., may act in time in evolving from one form a variety of the same. We will assume, taking an adapted example of Darwin's, that the earth in a certain field on Staten Island possesses accidentally certain ingredients or qualities which impart to the plant growing in it peculiar strength to certain tissues, or such nourishment that 
certain parts of the plant develop to a greater extent than others. Assume that this abnormal growth finds expression in an unusual development of the hairs that are found on the plants, especially those on the seeds. It is entirely an accident we will say, just as in the case of the sixth finger of the Maltese, and it would perhaps at a casual glance appear a very insignificant feature; yet the contrary holds. We know that the past history of this plant has been that the seeds dropped about the parent became fixed, threatening to choke it, fairly covering the ground, so that many were killed, while only the strong and hardy survived. These seeds are carrying on a silent struggle for existence, and the survival of the fittest is expressed by the one that outlives the rest. Now when this accidental longhaired seed drops from the seed-pod it is at once subject to a new condition. The hairs like sails offer a greater resistance to the wind that is blowing over the field than the hairs on the seeds of former generations, and the result is that having more sail in the aërial flight the seed attains a longer distance, outstripping all its short-haired or shortsailed companions, and instead of falling to the earth with a score of others, to grow up in a bunch and contend and struggle for the food elements in the soil, it is hurled into the air, as you have seen the wonderful seed of the thistle, and goes bounding along, to fall perhaps half a mile away in a new field where there is more room and liberty. When the seeds sprout and grow, the resultant plants will be hardier than their immediate parent. Now assume 
that a seed has found in its new home the same nutrition that gave rise to the original abnormal growth, what will be the result? The long-haired seeds will not only be perpetuated, but will, owing to the absence of a struggle with others, be more pronounced, and the seeds presenting the most sail, to use the expression, will still lead in the race, and go sailing away to new fields where the competition and struggle are less. Suppose these conditions prevail generation after generation, and the seeds have been carried by the wind over the Narrows, down on to Long Island, and into Connecticut, and if after many years, ages perhaps, we could compare a seed with one that fell on the original field on Staten Island, we should note that the wanderer had deviated from the original; that while it resembled it, it was now a variety, and had taken what we might term a step in the march of evolution. Now suppose that other seeds from this plant where they had fallen had become affected or influenced by some other nutritious element that tended to give them a thicker coating or harder case ; in others it produced a greater secretion of some essential oil, and so on. By following up their histories and finally in after ages comparing all the wanderers with the primitive stock, we should find that we had not one but several varieties. The latter are the result of accidental conditions existing throughout long or short eras of time, and this, in brief, is Darwin's idea of how the diversities of life have been produced.

It will at once occur to the reader that the conditions that might create a variation are almost endless. 
Heat, cold, food supply, geographical distribution, winds, water supply, prevalence of certain birds or other animals,- - all these are the factors which must be taken into consideration when studying this problem and in trying to trace out definite results.

Huxley, in defining Darwin's hypothesis, says: "As I apprehend it, it is that all the phenomena of organic nature, past and present, result from, or are caused by, the interaction of those properties of organic matter, which we have called Atavism and Variability, with the Conditions of Existence; or, in other words-given the existence of organic matter, its tendency to transmit its properties, and its tendency occasionally to vary: and, lastly, given the conditions of existence; by which organic matter is surrounded-that these put together are the causes of the Present and of the Past conditions of Organic Nature."

Darwin himself says: "No one ought to feel surprise at much remaining as yet unexplained in regard to the origin of species and varieties, if he makes due allowance for our profound ignorance in regard to the mutual relations of all the beings which live around us. Who can explain why one species ranges widely and is very numerous, and why another allied species has a narrow range and is rare? Yet these relations are of the highest importance, for they determine the present welfare, and, as I believe, the future success and modification of every inhabitant of this world. Still less do we know of the mutual relations of the innumerable inhabitants of the world during the many past geological epochs in its his- 
tory. Although much remains obscure, I can entertain no doubt, after the most deliberate study and dispassionate judgment of which I am capable, that the view which most naturalists entertain, and which I formerly entertained-namely, that each species has been independently created-is erroneous. I am fully convinced that species are not immutable; but that those belonging to what are called the same genera are lineal descendants of some other and generally extinct species, in the same manner as the acknowledged varieties of any one species are the descendants of that species. Furthermore, I am convinced that natural selection has been the main but not exclusive means of modification."

It will be seen, then, that the various forms of nature, animal or vegetable, are continually changing, affected by the conditions or circumstances which surround them, and that evolution is the term applied to the change.

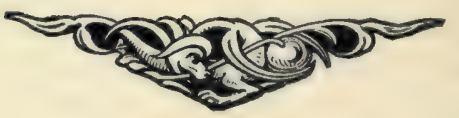




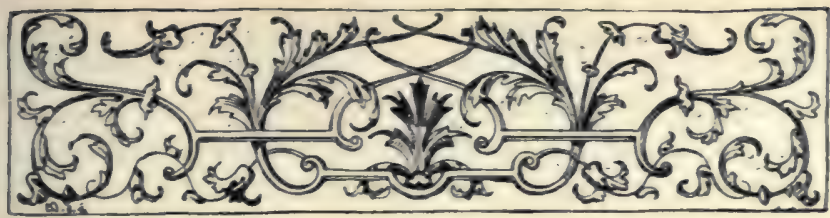

\section{CHAPTER XIX.}

\section{DARWINISM CONTINUED.}

How Change is Produced-Vast Eras of Time-The Age of the Earth-Evidences of Evolution-Extinct Animals.

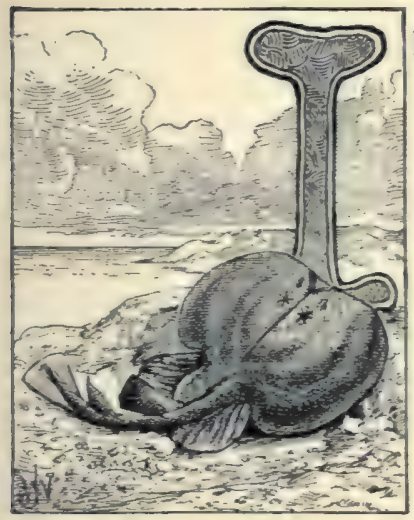

if we imagine that these changes have gradually been going on for unknown ages, periods which the mind of man cannot grasp, we begin to see the light ahead that Darwin saw.

In the present age geology and palæontology, or the history of extinct animals, through the investigations of Professors Cope, Marsh, Leidy in this country, 
and others in Germany and England, have become remarkably well understood. Though there is still a vast area unexplored, we know enough of the ancient earth and its history to enable us to view it comprehensively. If we could make a section of the crust we should find the rocks arranged layer by layer. At a certain depth would be what is known as the Eozoic rocks, which if they have contained life do not show evidences of it. Above this we find a layer containing shells and low forms, and so on up, layer after layer, for thirteen thousand feet in New York State, or nearly two miles of solid rock, nearly all the strata being characterised by peculiar forms of life. If we examine these, one after another, up through the crust, we notice that there appears to be an elaboration of structure the higher up we proceed. Thus in the Devonian, or just below it, we first find back-boned animals-fishes; then in a succeeding age reptiles; then milk-giving animals, and finally man. In other words, there has been an apparent evolutionary movement here, so that viewing the results we can easily imagine that one who had studied the rocks as did Darwin might arrive at the conclusion that he was looking at the different steps in the evolution of life.

How long was the thirteen thousand feet in New York forming? The mind fails to grasp the figures, nor can we realise it without taking up instances that are well defined and familiar. In one of the Western States there is an elevation, known as Amethyst Mountain, a mile or more high. One side has been worn away by the elements, so that it appears to 
have been cut down as with a knife, leaving a more or less sheer precipice. On the face of this can be counted twenty or thirty distinct forest levels. Thus at the base a forest is visible of trees standing upright; the trunks of large size but broken off about ten feet from the ground and completely silicified or turned into stone. The roots, like stone snakes, can be readily traced, while the trees and sections of trunks are so true to life that they might have been buried but yesterday. On top of these trees is seen a stratum of rock, which has given growth to another forest, which attained maturity and died down to form the birthplace of still another. So one after another these forests are piled up to the height of a mile. The reader is familiar with the time entailed in the growth of a forest of to-day, from saplings to trees of the largest size, hence can form some idea of the time which must have elapsed while these forests were dying and growing one upon another.

Those who have visited England and are familiar with the chalk cliffs of Dover have interesting testimony of the duration of time. This vast deposit is simply an ancient ocean bottom almost exactly identical with that being formed in the Atlantic to-day. By some convulsion of nature it has been elevated, and stands as a monument to the vast results attained in nature by the agency of minute organisms through long eras of time.

When the Atlantic cable was taken up for repair, it was found covered with a mud almost entirely made up of minute shells of rhizopods; and later investigations into the ocean bottom showed that 
everywhere, at a depth not greater than fifteen hundred fathoms, it was composed of these organisms. They filled the water, floating about, and in such numbers that it has been estimated that if they are as numerous, down to a depth of six hundred feet, as they are near the surface, there would be more - than sixteen tons of calcareous shells or carbonate of lime in the uppermost one hundred fathoms of every square mile.

These little creatures are continually dying, and the result is that a constant shower of their shells is dropping upon the bed of the ocean, and slowly tending to fill it up; how slowly can be understood from the minuteness of the animals. Yet we know that the enormous deposits of chalk, represented by the Dover cliffs, were formed by this silent rain.

The pyramids of Egypt are deposits of a small shell-nummulite; their accumulations on some ancient sea-bed forming the stone which was cut and piled up by the ingenuity of man. We wonder at these monuments, but how much more wonderful is the age they represent in the history of nature.

In England the Paleozoic strata is 57,154 feet in depth; the Secondary strata I3,I90 feet; and the Tertiary strata 2,240, according to Professor Ramsey; in all, 72,584 , or about thirteen miles of rock which has been piled up by animal deposits inch by inch.

Those who are careful observers, and who return to localities after an absence of many years, rarely notice any difference in a landscape. America has been inhabited by the white race for six hundred years, yet there has been little or no change in the 
appearance of the country. In England records show for centuries the measurements and limitations of estates upon which old oaks have been growing. The land looks the same; there is no apparent change; so that we may assume that the change of a thousand years would be scarcely noticeable, while in the matter of wear and tear a cliff five hundred feet in height would suffer a denudation of perhaps one inch per century for its whole length. Darwin estimates that the denudation of the wold in Great Britain must have required $306,662,400$ years, or say three hundred million years. A million, then, is but a drop in the bucket in the time since life began, and when endeavouring to imagine species as the result of Darwin's explanation, we must remember that periods beyond our power of appreciation are necessary to the result, and are an essential factor in evolution.

Having looked so far into Darwinism, having seen that the great naturalist outlines a theory and fully defines its scope, the question naturally arises, "Are there no proofs, no evidences to substantiate the belief?" And to this might be said, that the majority of leading biologists of to-day accept the Darwin hypothesis. The modern palæontologists have added to the information he accumulated, and many interesting evidences have been presented which are popularly called "missing links." Darwin says: "I am fully convinced that species are not immutable, but that those belonging to what are called the same genera are lineal descendants of some other and generally extinct species." 
This leads us to an examination of some of these extinct species which have been brought to the attention of science, and which we may consider the stepping-stones from the forms of to-day to an ancestor in the remote past. One of the most interesting examples is that of the horse. When white men first came to this country, the horse was not found here; indeed, there appeared to be no tradition of such an animal, and the Spaniard relied almost as much upon the terror these animals created in the land of the Incas, as they did upon their arms, the natives believing that horse and rider were one. Some of the horses of these adventurers and others escaped, and from them descended what are known as the wild horses of North and South America.

That horses were not found here by the white discoverers is to some extent singular, as it is now well known that these animals existed here in great numbers in the Quaternary and Tertiary times of geology; some climatic or other change producing their complete extirpation. Some idea of the extent of the distribution of horses in these early days can be realised when it is known that twelve species have been discovered in the Quaternary deposits, and more than thirty in the Tertiary; so that scientists have a remarkably complete chain of evolutionary evidence in their remains. The smallest of these, the Hipparion of the Eocene, was about as large as a fox. It had large canine teeth, three toes upon its hind feet, and four perfect toes and a splint on the forefeet. In this horse the head 
and neck were elongated, and the place for the bit or diastema was well defined, and develops materially as we follow the line down. Compare this form with the horse of the Lower Miocene (the Mesohippus), and we find that the latter was larger, being now about the size of a sheep. It has three toes behind and in front, while the fourth toe, which we saw in the previous form, is reduced to a mere splint. Following it, in the Miocene proper, was the Miohippus, in which the toes are about the same, though the fourth one, or splint, is hardly distinguishable. Now, the animals, though small, had well-defined horse-like shapes. Passing to the next form in the Lower Pliocene, we find a skeleton about as large as that of the present donkey. The splint has entirely disappeared, and there are three toes, the two outer ones being short, there being very evident disposition to rely upon the middle one, which was larger and stouter than in previous forms. Moving upward to the Pliocene, we come to a horse which scientists call Pliohippus, and which was very similar to the horse of to-day. The middle toe was now the hoof, while the other toes were useless splints. Another step brings us to the Quaternary and present horse, in which the middle toe has become the hoof, upon which the genus Equus stands, while the two toes are still represented by the disappearing side splints.

The striking nature of this evidence is shown in the accompanying diagram.

In referring to these animals Professor Marsh says: "The most marked changes undergone by 
these successive genera are the following: ist, increase in size, from Orohippus, as large as a fox, to the modern horse; $2 \mathrm{~d}$, increase in speed through concentration of the limb-bones; $3 \mathrm{~d}$, elongation of the head and neck and modification of the skull. The increase of speed was a direct result of a gradual and striking modification of the limbs. These were slowly concentrated by the reduction of their lateral elements and enlargement of the axial one, until the force exerted by each limb came to act directly through its axis in the line of motion. This concentration is well shown in the fore-limb. There was, Ist, a change in the scapula and humerus, especially in the latter, which facilitated motion in one plane only; $2 \mathrm{~d}$, an expansion of the radius and reduction of the ulna, until the former alone remained entire and effective; $3 \mathrm{~d}$, a shortening of all the carpal bones and enlargement of the median ones, ensuring a firm wrist; $4^{\text {th }}$, an increase in size of the third digit at the expense of those on each side, until the former alone supported the limb. The latter change is clearly seen in the accompanying diagram, which represents the forefeet of four typical genera in the equine series, taken in succession from each of the geological periods in which this group of mammals is known to have lived. The line of descent appears to have been direct, and the remains now known supply every important intermediate form. Considering the remarkable development of the group throughout the entire Tertiary period, and its existence even later, it seems very strange that none of the species should have survived, and that we are indebted for our present horse to the Old World." 
These changes were produced only after successive ages representing vast eras of time.

From this brief review it will be seen that Darwinism assumes that the side splints so familiar in the horse of to-day indicate an ancestry in which the splints were more fully developed. In other words, the splints are the remains of organs which in the course of the development of the animal have disappeared.

Adopting this line of argument Darwin would point to the teeth in the embryo of the whalebone whale, which do not appear as the animal grows, as evidence that the giant animal in the remote past possessed teeth, so the rudimentary pelvis, hip-bone, thigh, and leg bones suggest that at one time this huge creature possessed hind legs. In the Greenland whale especially, the hip- and knee-joint, with some of their muscles, are well defined beneath the skin, so that we can imagine that at one time in the remote past the whale was a shore-loving creature, which finally became more aquatic in its habits, and the hind legs, like the many toes of the horse, disappeared.

Among the early birds of this country the wonderful Odontornithes, or birds with teeth, discovered by Professor Marsh, we have examples of connecting links striking in the extreme, and pointing to an ancestry so remote that the imagination almost fails to grasp the reality, and the mind is bewildered by the testimony that shows conclusively that by following back the history of our feathered friends we should be led imperceptibly but surely into the domain of the reptiles. 
One of the most interesting events of the scientific world of America in the past twenty years was the announcement by Professor Marsh that he had discovered in the ancient sea-bed or shore of the West the remains of birds which possessed reptilian teeth and were evidently descendants of reptiles. This announcement was received with incredulity by the scientists of Europe; but their doubts were silenced when the remains of not one but scores of specimens were deposited in the Yale museum at New Haven, showing fully the remarkable nature of the diseovery. Professor Marsh states that the remains found by him represent birds which had remarkable reptilian affinities and were undoubtedly descended from some remote reptilian ancestor.

The most striking form discovered was the one called by him Hesperornis regalis. It represented a bird about six feet in length, resembling to some extent the loon of to-day. It was an aquatic bird, but flightless, being without a vestige of wings. Its neck was long, its feet extremely large, and its pointed bill, armed with sharp recurved teeth, admirably adapted for securing and holding prey. The size of the latter was not material, as the lower jaw was united in front by a cartilage, as in the snakes, giving them the power of swallowing a fish of large size. That a bird should be provided with teeth is extraordinary; but in this case they were almost identical with those of reptiles.

In referring to this bird Professor Marsh says: "Having thus shown what the skeleton of Hesperor$n i s$ is, and what its mode of life must have been, it 


\section{Remarkable Birds.}

remains to consider the more important question of how the peculiar combination of general and specialised characters manifested in its structure originated. The two most striking features of Hesperornis are the teeth and the limbs, and an inquiry in regard to them first suggests itself. The teeth of Hesperornis may be regarded as a character inherited from a reptilian ancestry. Their strong resemblance to the teeth of reptiles, in form, structure, and succession, is evidence of this, and their method of implantation, in a common alveolar groove (Holcodont), conforms strictly to what we have in one well-known group of reptiles, exemplified by Ichthy. osaurus. This method of insertion in the jaw is a primitive dental character, quite different from what we should naturally expect as an accompaniment of the modern style of vertebra, and is a much lower grade than the implantation of the teeth in distinct sockets (Thecodont), a feature characteristic of another group of Odontothores, of which Ichthyornis is the type. These teeth indicate unmistakably that Hesperornis was carnivorous in habit, and doubtless was descended from a long line of rapacious ancestors."

Equally remarkable was the Archaopteryx - a bird discovered in Germany. Here it is supposed was a bird but partly feathered, representing the time when feathers were developing. Its beaks were armed with teeth, while its tail was an elongation of the vertebræ, like the tail of a cat, from the sides of which grew feathers, so that when the reptilian bird flew, its tail constituted a rudder or guide. These 
singular creatures, with the gigantic Pteranodons were links in the wondrous chain of early life-evidences of a remarkable ancestry. A volume could be filled in describing the many recent discoveries which naturalists of to-day consider as evidences of the correctness of the deductions of Darwin. To him the story of nature was plain and simple; the Giver of all things created life; this, acted upon by the natural conditions of its environment, produced the varieties, which, in turn, in the long eras of time, became species; from these genera were evolved; and so the change went on, populating the world.

The story of this evolution is told in the "Origin of Species," "The Descent of Man," and other works of the great naturalist, which mark epochs in the history of scientific thought.

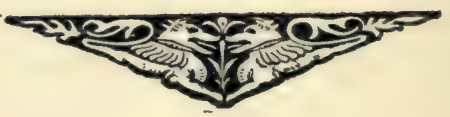




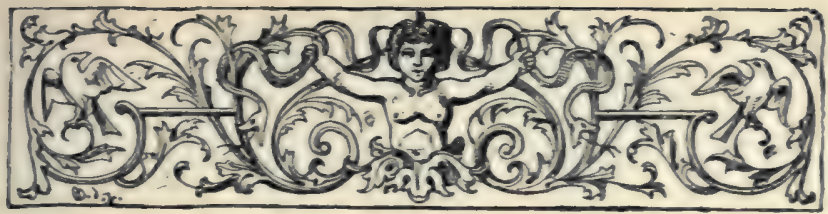

\section{CHAPTER XVIII.}

\section{THE DARWIN MEMORIAL.}

Addresses by American Scientists: Dr. Theodore Gill-W. H. Dall -Major John W. Powell-Richard Rathbun-Charles V. Riley - Lester F. Ward-Frank Baker-Frederick W. True.

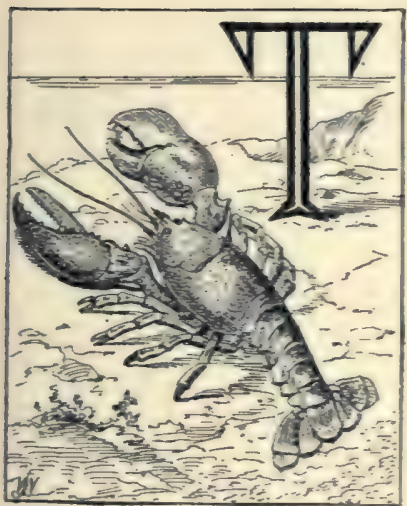

The American societies were unanimous in their appreciation of his greatness, and the memorial of the Biological Society of Washington was particularly interesting. The announcement of the death of the distinguished scientist was officially made to the society at its meeting of April 28, I882, at which 
it was voted that the next meeting of the society should be a Darwin memorial. The following committee was appointed to carry it out ; Messrs. Goode, Riley, Ward, Rathbun, and Gill. The result of their action appears in the memorial of the society, which consists of a series of papers, read by distinguished leaders of scientific thought in America, on the various branches of science with which Darwin was identified.

These papers give the most comprehensive view of Darwin's scientific attainments from a purely American standpoint, ever published.

The meeting of the Biological Society was called for the 12 th of May, a little over a month after the death of the great naturalist, and in the presence of a large and distinguished audience, among which were representatives of many of the leading scientific societies of the day, the following papers which will always remain permanent additions to Darwinian literature, were read:

THE DOCTRINE OF DARWIN.

BY THEODORE GILL, A.M., M.D., PH.D.,M.N.A.S.,

Smithsonian Institution.

The chief for many years of the leaders in science knows no longer the world he erstwhile knew so well. Charles Darwin has closed a life illustrious in the annals of biology, scarce full of years but very full of honours.

How fruitful was that life and how potent its influence on philosophy and on sociology the united 
voice of the civilised world proclaims-how grievous the loss the lamentations of mankind testify. Less than a quarter of a century has elapsed since the publication of "The Origin of Species by Means of Natural Selection." How great is the contrast between the beliefs and practice of naturalists before its appearance and those of their present successors! He would, indeed, have been a bold man who would have predicted that, in two decades after its appearance, the views therein promulgated would be universally accepted and be taken as the recognised platform of biologists. But the incredible has actually happened: all the students of nature, and in every land; zoölogists and botanists, palæontologists and geologists; in America and Europe, at the confines of Asia, the extreme of Africa, and in distant Australia,-all meet on common ground as evolutionists ; all recognise to a greater or less extent the operation of natural selection in the survival of the fittest. To appreciate the cause of the profound impression produced by the deceased naturalist's greatest work, some reference to the antecedent and succeeding conditions is fitting.

It had been, from time immemorial, a generally accepted idea that the living beings which people the globe had, in some mysterious manner, been each "created" separately; but how, few ventured to express in words, for the mere attempt to do so conjured up such strange fancies that the intelligent mind drew back in revolt and refused to consider them. Now, it is a recognised scientific creed that the animals and plants which have successively in- 
habited the earth were the descendants, with modification, from previous inhabitants since the dawn of life. A glimmer of the truth had now and then occurred to contemplative students. Philosophers had ventured to think that living forms like ancient ones might have descended from them. The investigators in various departments of biology had gradually deduced generalisations which all tended in a similar direction. The taxologists, in their very nomenclature, compared the animal kingdom to a tree of which the principal types were "branches" diverging from a common trunk, while the minor groups were successive offshoots; and the idea of genetic relationship suggested by the various degrees of likeness was expressed in the names conferred on other groups- "tribe," "family," etc. The embryologists had recognised a coincidence between the stages of development of the "superior" animals and the adults of animals inferior in the system. The palæontologists had discovered an approximate coincidence between the successive inhabitants of the earth and the successive stages in the development of the living animals of the same types. The series of facts thus obtained had even, to some extent, been co-ordinated.

All these series of facts were such as would have been the result of the derivation of existing types from previous ones. But the possibility that the seeming was the real did not commend itself to the consideration of naturalists. Instead thereof, it was assumed that the facts were "in accordance with a plan of the Creator"; that the Deity had conceived 
a few patterns, and that by those he constructed the animals which successively appeared on the globe, to be in time swept off and replaced by others. If answer was made that such was a puerile conception of creation and that it limited the power of Deity, excessive anger was displayed, and its opponents called infidels and atheists. But even those who doubted whether the accepted views of creation were tenable, hesitated to take the alternative view. An efficient factor in variation remained to be discovered, and a full presentation of the data had yet to be made.

It was in 1859 that the desiderata indicated were supplied in "The Origin of Species by Means of Natural Selection." "Variation under domestication" was compared and contrasted with "variation under nature." The "struggle for existence" which is the result of the progressive increase of living beings was considered, and "natural selection" was designated as the factor which determined the development and existence as "species" of forms which had descended, with modifications, from countless antecedent generations. With the successive changes in temperature and other conditions ensuing in the ever-changing world, the animals and plants which peopled it were compelled to keep pace by corresponding changes in structure, or to give place to others who could adapt themselves to the new conditions.

So much were the views thus enunciated opposed to the current ideas that a brief period of astonished silence ensued, and men felt about before they could realise their full purport, or that such opinions were 
broached in sober earnest. Then followed on every hand torrents of detraction and abuse. The naturalists of the old school and the priests of revelation met on common ground, and loud and bitter was the denunciation. Numerous were the arguments against the new theory.

But why this great turmoil and uproar? Darwin was not the first to believe that species had been derived and not created. So had philosophers believed before; the grandfather of Darwin believed and urged the belief; a great naturalist at the commencement of the century-Lamarck-boldly and wisely formulated a theory of evolution; the "Vestiges of Creation" took up the view, and gained marked attention in Britain. Even a clergyman of the English Church, the Savilian professor in orthodox Oxford, the Rev. Baden Powell, in I 855, had considered the "Philosophy of Creation" in a "masterly manner," and Darwin bore testimony that nothing can be more striking than the manner in which the enlightened priest showed that the introduction of new species is a regular phenomenon in contradistinction to a miraculous process. Darwin was not the first even to conceive of the principle of natural selection. An American resident in Englañd, Dr. W. C.Wells, as early as $18 \mathrm{I} 3$, had recognised the operation of the principle in the distribution of the human race. In 1831, Patrick Matthews also appreciated the principle of natural selection; so Darwin himself witnesses.

It was not, then, the mere enunciation of the theory of evolution, nor of the principle of natural 
selection, that characterised the "Origin of Species," and drew the attention of mankind to it. It was the recognition of the incessant and universal operation of the factors, the masterly co-ordination of the facts of biology - zoölogy, botany, anatomy, general morphology, physiology, embryology, palæontology -and geology, the marshalling in orderly array and concentration in one direction of all natural knowledge, the force of the logic, the clearness of the exposition, the judicial candour of the argument, that arrested men's attention, and provoked serious consideration of what before had been ignored as being beyond the domain or possibilities of investigation. In the time of Lamarck the world was not ready for a consideration of the question. Lamarck's was the prophecy of intuitive genius-genius the greater in that the facts that had been garnered were few. The "Vestiges of Creation" was so replete with errors of fact and misconceptions as to attract more attention to the fault of its details that to the logic of its argument. The principle of natural selection had been applied to very special fields by Wells and Matthews; no evidence had been furnished of its wide extension, and it even occupied a subordinate position in the thoughts of those investigators.

The author of the "Origin of Species" was a different man from his predecessors, and lived in a happier time. The facts had been accumulated and coordinated; men were ready to consider the reason why facts were such, and none was better fitted than Darwin-I should rather say none was so well fitted 
- to arrange and present the facts and to draw the deductions therefrom. Ever a close observer, practised in many lands, student of all nature-especially skilled as a geologist, a botanist, and a zoölogistendowed with a severely judicial mind, honest above all, none like him had ever grappled with the mystery of creation. For more than twenty years he had pondered on the subject ; with impartial severity he had weighed the evidence. He was, perforce, led to the conclusion that all the living had been derived from past forms, with modifications incident to individuality; the sums of the divergences, small in themselves, became large in the aggregate, became enormous in time. The increasing beings, crowding upon each other, invading each other's domains, struggled for the life into which they were born. Happy were those possessing some slight advantage - strength, swiftness, dexterity, or adaptability resulting from modification of structurefor they could procure place or food at the expense of their competitors, and the characters that gave them victory secured, likewise, the temporary ascendancy of their kind. How great is this variability our domesticated animals attest; how ancient is our globe geology teaches; that the race is to the strong or the cunning observation of inferior nature assures. With known variability, time, and space, what could not result? Which, then, was the more probable, that Nature-or, if you will, the Creator - had always operated under law, or that there had been constant interference?

Thus were the issues fairly joined. On the one 
hand, Creation was the rallying cry; on the other, Evolution and Darwin. But what meant the opposed terms? It is surely but reasonable to ask the question. The evolutionists conceded the reasonableness, and gladly accepted the ordeal. Could less be required of the creationists? In reverential mood would I submit the alternatives. If they repel, blame not me. I have long and fruitlessly searched for better.

Creation implies the actual fashioning of forms in full panoply, and with all the characteristics of their kind. But when it was asked how this had been effected the answer was vague and evasive. Did "elemental atoms flash into living tissues?" Was there vacant space one moment and an elephant apparent the next? Or did a laborious God mould out of gathered earth a body to then endue with life? The questions are surely pertinent, for only by such means can we conceive of creation. But passionate disclaimers and angry denunciations greeted him who would frame such conceptions in exact language. Metaphysical jargon and rhetoric about divine purposes might sophisticate, but could not answer.

Evolution denotes the derivation of living beings from preceding in endless succession. Variation in progeny, limited heredity, and time are its correlatives. These being conceded, the peopling of the globe with its life, past and present, is conceivable.

What was the evidence to support the conflicting conceptions?

For creation it was urged that the universal consensus of mankind supported it ; that divine revela- 
tion taught it ; and that the diversities and specialisation of organic forms forbade the idea of their derivation from a common parentage.

The universal consensus of mankind maintained till the sixteenth century the doctrine that the earth was flat; that the sun and other planets circled round the earth; and that the earth was the great centre of the universe. The universal consensus of mankind for thousands of years is not the universal consenus of the enlightened man, nor of the present century.

The teachers of revelation have been often mistaken. Many are they who once were contemned and denounced because their utterances were not in accordance with the opinions of their day, who are now accepted as the champions of a purer religion. One of the wisest priests of England has said that "with a certain class of religionists every invention and discovery is considered impious and unscriptural as long as it is new. Not only the discoveries of astronomy and geology, but steam, gas, electricity, political economy, have all in their turn been denounced; and not least chloroform. Its use in parturition has been anathematized as an infraction of the penalty, pronounced on Eve!"* It is not I, but a great clergyman, who expresses such sentiments.

The objection that the differentiation and specialisation of organic beings gainsay their derivation from a common source is a most weighty one. In

* Rev. Baden Powell's "Essay on the Spirit of the Inductive Philosophy," etc., p. 455. 
the infancy of our own knowledge it was unanswerable, and the less we know of nature the more we are impressed with these diversities. It is not, however, simply a question of whether evolution is true; but which is the more probable of two alternativesthat all the phenomena which point in one direction and which could have occurred in natural sequence, have taken place in such sequence; or that direct creative intervention has ensued again and again, when the same ends could have been produced without such intervention.

Nature was true to her disciple, and herself furnished the replies.

It was contended that if evolution were true, the evidence should be forthcoming in the existence in previous geological epochs of forms of a generalised character intermediate between still earlier ones and later widely separated forms; and that of such there were very few.

The graves of the distant past gave up their dead, and the ossuaries of our own far West yielded most cogent testimony to the truth. Forms from the Eocene and later beds, resurrected by the wand of the anatomist, rising in successive lines behind the wide gaps in the living files, proclaimed that all were of one blood, and showed the genealogy of the contemporaries of man.

Many were the forms thus connected. Few are those that may be mentioned on this occasion. The horse-like animals, the rhinoceroses, and tapirs, are so unlike, that proof of their derivation from one source might be thought to be impossible. But 
as we go back into the ages we find equines with lateral digits and hooflets becoming larger and longer, teeth shorter and more generalised, skeletons less characteristic; rhinoceroses with cutting teeth, and more slender forms; tapir-like animals without the peculiar tapirine teeth, with rhinocerotoid skulls, and with otherwise modified structure; all these, accompanied by innumerable other modifications, till finally we are almost at a loss to tell whether it is a horse-like, a rhinocerotoid, or a tapiroid animal that is before us, and they become lost in earlier forms with special characters of their own. And as we go still further back we are confronted with still other forms that are connected by series projected backward from the ruminants and from the elephantids. We do, in fine, know the genealogy of our own contemporaries-imperfectly, it is true, but still we know it.

It was objected that animals were segregated by such very wide intervals that they must be isolated in different branches, and that there could be no community of structure between such branches; they expressed fundamentally different plans of structure.

One by one zoölogy, anatomy, and embryology supplied the links between the old branches; the branches were at length completely uprooted, and it has even become a matter of simple convention what should be considered major groups. Plans of structure can no longer be claimed to be peculiar to different types.

That branch of which man is the primate-the 
vertebrates-was supposed to be perfectly unassailable and isolated; but zoölogy and anatomy have revealed to us amphioxus, and embryology the earlier stages of the tunicates. The evidence is now conclusive that these forms which once appeared to be among the most distant, are now the most closely related. The affinities of the tunicates with invertebrates are evident, and thus we may look far back to that time when vertebrates did not exist, but when the common ancestors, from which they and the related invertebrates should diverge, held sway.

It was even pretended that the evidence was insufficient to show that variation was possible or could be propagated.

From every hand testimony was forthcoming. The breeder could point to every domesticated animal-the horticulturist and pomologist to all cultivated plants-the systematist and zoögeographer to the limits of species which varied with knowledge of their distribution-the palæontologist to the gradation between the extinct forms and widely separated living species, as well as to that between forms which lived in successive earlier epochs.

It was urged that the Darwinian theory was opposed to revelation, and subversive of Christianity.

As students of nature and seekers after truth alone-so far as nature is concerned-we only ask whether the views of Darwin are true or not. But now, from many a pulpit, and from the most enlightened of the clergy, we hear the claim that evolution is in perfect accordance with revelation, and is a witness to the power, prescience, and goodness of God. 
It was contended that acceptance of the teachings of Darwin would have a pernicious tendency, and entail riot, lawlessness, and crime in the world.

A long life of singular purity and blamelessness in the person of Darwin was an answer. An unsullied heritage from an ancestor entertaining like views has been transmitted to heirs of his body without flaw. Sons of the great philosopher continue the studies of their great sire, and worthily wear the heavy mantle left to them.

One after another the scientific opponents of evolution became convinced of its verity, or died out. The naturalists of a new generation with one accord accepted "Darwinism" as a starting-point for their more profound studies. The methods and aims of biology became changed. Biology became exalted from empiricism into a science. Long before "The Origin of Species" had even "come of age," acceptance of its teachings had become an essential of scientific creed, and Darwin was acknowledged to have effected a greater revolution in science than any Englishman since the time of Newton. Most meet was it then that he should rest by the side of his great predecessor, whose rival he will ever be in fame.

\section{BIOGRAPHICAL SKETCH.}

BY WILLIAM H. DALL,

Honorary Curator, Dept. of Mollusks, U. S. National Museuri.

Charles Robert Darwin, son of Dr. Robert Waring Darwin, F.R.S., and Emma Wedgwood, grandson of Dr. Erasmus Darwin and Josiah Wedgwood, was born at Shrewsbury, England, February I2, 


\section{Dall's Sketch.}

1809. He died of disease of the heart at his residence, Down Court, Beckenham, Kent, at 4 P.M., April 19, 1882, and consequently had attained the age of seventy-three years, two months, and seven days. At Shrewsbury his childhood was passed and his education was obtained at the once famous Shrewsbury Grammar School, presided over by the Rev. Dr. Samuel Butler, afterward Bishop of Litchfield and Coventry.

At the age of sixteen he entered the University of Edinburgh (1825) where he remained two years. Even at this early period he had become a student of natural history, and read his first scientific paper before the Plinian Society. It was "On the Movement of the Ova of Flustra," one of the incrusting marine corallines.

In 1827 he entered Christ's College, Cambridge, where he graduated as a Bachelor of Arts four years later. Here he fell under the influence of the teachings of Prof. John Stevens Henslow, an excellent botanist, whose instruction doubtless did much to determine the field of study subsequently occupied by his pupil.

In I83 I Captain Fitz-Roy, R.N., offered to share his cabin with any competent naturalist who would accompany him on his prospecting voyage to South America in H. M. S. Beagle, detailed for surveys in that region. Mr. Darwin, then only twenty-two years of age, offered his services, with the stipulation that he should control the collections made, and was accepted. The Beagle sailed November 27, 1831, from Plymouth, and returned to England on the 2d of October, 1836. During a large part of the voyage 
Mr. Darwin suffered greatly from sea-sickness, or some difficulty which simulated it, and which, in some form, returned at intervals throughout his whole life, as sudden fits of illness which prostrated him for days together, and which were followed by long periods of wakeful convalescence. Under the circumstances, the amount of keen and patient observation, the vast accumulation of facts, and the extensive collections obtained by Mr. Darwin during his voyage, appear more marvellous than ever.

After his return his health was much shattered, and his studies more or less interrupted for some years. He took his Master's degree in course, and shortly after his return was elected a Fellow of the Royal Society (of which his father and grandfather were previously Fellows), and of the Geological Society, of which last he was made secretary.

In 1839 he published his epoch-making work " $\mathrm{A}$ Journal of Researches into the Geology and Natural History of the Various Countries Visited by H. M. S. Beagle" ; the first of that long series of investigations to which his life was devoted, and the publication of which revolutionised the study of biology, and gave to Darwin a position as a naturalist unparalleled in the history of science.

In the same year, I839, Mr. Darwin married his cousin, Emma Wedgwood, and retired to the secluded and beautiful district of Kent, where, in his country-house of Down Court, near Orpington, more than forty years of his life were spent. The district is purely agricultural, a plateau of chalk, some four hundred feet above the sea, interrupted by the wavy 
hollows characteristic of the English chalk country, with beech woods here and there on the slopes. His dwelling is one of the old square-built, red-brick mansions of the last century, to which has been added in more recent times a gable-fronted wing, with another square-built wing and pillared portico on the corresponding side. Shut in and almost hidden from the roadway by a high wall and belt of trees, it offers ideal seclusion for a quiet student. On the southern side the walled garden opens into a secluded meadow bounded by a tract of underwood through which there is a lovely view of the narrow valley which descends toward Westerham.

Here, and in the by-paths of adjacent woods and meadows, Mr. Darwin was accustomed to take daily exercise with a characteristic regularity. Up to ten or twelve years ago, his tall figure, mounted on a favorite old black horse, was a familiar object in the country lanes. This animal fell and died suddenly one day, after which it was noted that Mr. Darwin rode no more. His invariable hours for walking, in these later years, were seven in the morning, noon, and four o'clock in the afternoon, usually accompanied by one or more of his sons; one of whom, Mr. Francis Darwin, has long been established as a surgeon in the hamlet of Down. His habits were extremely regular. He rose at six, took a cold plunge bath (which was repeated in the evening), breakfasted alone, and after his first morning walk was usually in his library by 8 A.M. At nine he would spend a little time in the dining-room opening his mail, and in the evening would linger an hour or 
two in the society of his family, or that of some of his scientific friends who occasionally visited him; but the greater part of his time was spent in his library, his garden, and the adjacent grounds. A few friends, among whom were Sir John Lubbock and Dr. Farr, near residents, were often with him, and with such he was social, frank, and ever ready to enjoy a joke or frolic; with all men he was unpretentious, kind, and devoid of any artificiality of manner; but his life was essentially a secluded one, as may be judged from the fact that the news of his death did not reach London until noon of the following day.

Nevertheless, his life was far from solitary, for his family formed quite a colony in itself until the children reached maturity. Two children, a boy and a girl, were lost in infancy; one dying in 1842 and the other in 1858 , and are buried in the village churchyard of Down, near by some of the Wedgwoods.

In the family who lived Mr. Darwin was fortunate. His eldest son, William, is a banker at Southampton; the second, George, took high honours at Cambridge, and is now a Fellow of Trinity College and a distinguished mathematician; the third, Frank, having inherited his father's delicate constitution, acted as his secretary; the fourth, Leonard, an officer of artillery, has distinguished himself in the direction of astronomy; the fifth, Horace, is an excellent mathematician. One married and one unmarried daughter complete a family whose constant care has been to relieve its head from any trouble and anxiety.

Mr. Darwin has always been in easy circumstances, financially, so that he could use his time as he chose, 
without care. When young he pursued field-sports, with the combined interest of the hunter and the naturalist; in later years he found his chief relaxation in reading popular novels. His work was taken up with great method, and he never wrote for more than two hours at a time.

In 1853 he received the gold medal of the Royal Society for his various works; in 1859 that known as the Wollaston medal from the Geological Society; in $187 \mathrm{I}$ he received the Prussian Order of Knighthood "For Merit," and was elected a corresponding member of the Austrian Academy of Sciences; and in 1878 , foreign associate of the French Academy. $\mathrm{He}$ received honorary degrees from Leyden and Cambridge, and other scientific honours almost without number.

His death was unexpected. He had been slightly unwell for several weeks, and the weakness of the heart's action was such that he was not permitted to ascend the stairs, but, in the main, he was still able to pursue his ordinary routine. On Tuesday morning Sir John Lubbock found him apparently about as usual. That he was seriously ill, was first known in the village Wednesday afternoon by the arrival of his groom on horseback, horse and man reeking with foam, having galloped for ice six miles and back from the nearest point where it could be procured; but in vain, the relief arrived too late, Charles Darwin had already passed away, surrounded by his family, including several of his sons, Mrs. Darwin, and a married daughter. On the 26 th his mortal remains were laid in Westminster Abbey, near by the ashes of 
Isaac Newton, and were followed to the tomb, not only by dignitaries of Church and State, but by the universal reverence of the scientific world.*

\section{DARWIN'S CONTRIBUTIONS TO PHILOSOPHY.}

BY JOHN W. POWELL, PH.D., LL.D., M.N.A.S.,

Director of U. S. Geological Survey, Director Bureau of Ethnology, Smithsonian Institution.

Many are the definitions of philosophy. If we wish not to define what is true philosophy, but simply to define the term in all its uses when referring to all times and all men, this definition will do: Philosophy is the explanation of the phenomena of the universe.

Now, the phenomena of the universe are embraced in many vast categories.

First, we have the constitution of the heavenly bodies, and their real and apparent motions to be explained. What are they, and how came they to be what they are?

Then we have the earth itself; its forms, its lands and seas, its mountains and valleys, its rivers and lakes, the winds which blow about it, the storms which fall upon it, the lightnings that flash athwart the sky, the thunders that roll among the clouds. What are all these things, and whence came they, and why are they? Again, in the constitution of the earth we find rocks with their minerals, and geo-

* It is hardly necessary to state that this sketch is a compilation from all the different sources which happened to be available at the time. 
logic formations with their fossils. What are rocks and minerals, formations and fossils, and whence came they?

Look at the innumerable forms of plants covering the earth with verdure-the whole vegetable kingdom on the land and on the sea; forests, mosses, and confervæ. Who shall explain the meaning of the phenomena of the vegetable kingdom?

The oceans teem with animal life; reptiles crawl over all the land; the hills and the valleys, the mountains and the plains, are all inhabited by beasts; and the air itself is populated. Who shall tell us of all the living things, and then explain life itself?

Turn to the contemplation of man, organised into tribes and nations; man possessed of innumerable languages; man engaged in arts and industries; man endowed with reason and will; man in search of moral principles to guide his conduct. Whence came this man, and whither does he go.

Among all tribes and nations of the globe, and in all times, men have sought to discover the whence, the how, and the why of all things-the phenomena of the universe.

The explanation of the universe is philosophy.

The philosophies of the world may be classified as-

\section{Mythologic. \\ II. Metaphysic. \\ III. Scientific.}

Mythology and science constitute the two grand systems of philosophy, but between them stands 
metaphysic philosophy as a stepping-stone from the former to the latter.

In the lower stages of society, philosophy is purely mythologic. All savage and barbaric peoples explain the phenomena of the universe by a system of myths. A mythology is always a growth, and among every people there grows up by the employment of diverse and superficial analogies-curious suggestions - a body of mythic explanations which constitute its philosophy.

Among the Wintuns of California the world is three-storied. There is a world-a great chamberabove, and there is this world, and a world below. The waters fall from the world above because the sky, the floor of that upper world, leaks; and the waters come from the world below through the springs that issue from the flanks of the dead volcanoes of that land; so the waters from above and the waters from below meet and flow down the great Sacramento to the sea, where again they divide; the waters from above taking their way. to their upper home, and the waters from below taking their way to the lower world.

The mountains were formed by the great molegod, who crawled under the land and upheaved the mountain ranges that stand on either side of the Sacramento Valley. And so they explain all of the phenomena of the universe with which they are acquainted, in a system of myths which constitutes the philosophy of the Wintuns.

Now such a system of philosophy, a mythology, is found in every savage and barbaric tribe of the world. 
But there came a time in the history of mankind when some of the peoples changed their philosophy - their explanation of the phenomena of the universe-by changing their methods of reasoning.

\section{Origin of Metaphysic Philosophy.}

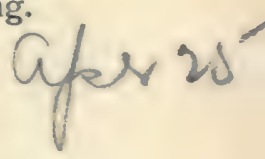

From three to two thousand years ago, Europe, Asia, and Africa established a commerce in ideasan exchange in philosophies carried on by the navigation of the Mediterranean. During that and some previous time there were built on the shores of this sea many cities. Through the building of these cities, and through the industries and arts which sprang up therewith, society was reorganised and placed upon a new basis-tribal society developed into national society-barbarism into civilisation.

The peoples of these cities spoke diverse languages, and entertained diverse mythologic philosophies. Through the intercourse which sprang up between them, each learned of the philosophy of the other, and the scholars of that day attempted to discover in all of these diverse mythologies a common body of truth upon the theory then widely accepted, that they had all sprung from a common source-a primitive philosophy itself the truth, -and that all the philosophies then existing were degenerations therefrom. This line of investigation led to a curious result.

All of the mythologies of the cities of the Mediterranean were found to be baseless-each a fabric 
of poetic but superficial analogies. In the mental activity of that time many new philosophies were proposed, diverse and contradictory ; and the wisest philosophers said, "How shall we know the truth?" And they endeavoured to discover some criterion by which truth should be known. This resulted in the development of formal $\log i c^{\star}$ as a testing machine into which opinions were put for the purpose of sifting truth from error.

Now the machine called logic, the tool of the metaphysician, is curiously constructed. Its chief hypothesis is that man was primitively endowed with fundamental principles as a basis of reasoning, and that these principles can be formulated. These fundamental principles are supposed to be universal, and to be everywhere accepted by mankind as selfevident propositions of the highest order and of the broadest generalisation. These fundamental propositions were called major propositions. The machine, in formal logic, was a verbal juxtaposition of propositions with the major propositions at the head, followed by the minor propositions, and from this truth was supposed to flow.

This formal logic of the Aristotelian epoch has lived from that period to the period of science. Logic is the instrument of metaphysics, and metaphysic philosophy, in its multifarious forms, is the product of logic. But during all that time-2,000 years-no truth has been discovered, no error has been detected by the use of the logical machine. Its fundamental assumption is false.

It has been discovered that man is not endowed 
with a body of major propositions. It is found that in the course of the evolution of mind minor propositions are discovered first, and major propositions are reached only by the combination of minor propositions; that always in the search for truth the minor proposition comes first, and that no major proposition can ever be accepted until the minor propositions included therein have been demonstrated.

The error in the metaphysic philosophy was the assumption that the great truths were already known by mankind, and that by the proper use of the logical machine all minor truths could be discovered, and all errors eliminated from philosophy. As metaphysic methods of reasoning were wrong, metaphysic philosophies were false; the body of metaphysic philosophy is a phantasmagoria.

\section{The Origin of Scientific Philosophy.}

While metaphysic philosophers have been playing with their logical kaleidoscopes, another body of philosophers have been at work gathering the materials for the philosophy of science. Their method is to collect facts and to discover their relations, and they accept no conclusions that are not reached by this method. All other conclusions they hold as undetermined or indeterminate.

And now must be given a definition of science. Science is the discernment, discrimination, and classifcation of facts, and the discovery of their relations of sequence. This is a simple statement, but for its full comprehension a little illustration may be necessary. 
A savage hears the voice of his fellow-man, he hears the voice of the beast, and of the bird; he also hears the noise of the thunder, and he supposes that the noise is a voice. In these cases he discerns noises, but he does not discriminate one noise from the other, and supposes them all to be voices, and that the noise of the thunder is the voice of the Thunder Bird. To understand facts we must not only discern, but discriminate.

The next step in the progress of science is classification. Having discerned and discriminated facts, they must be classified-all those of like nature thrown together. All noises made by living beings for conveying intelligence may be grouped into one class and called voices; all noises made by explosions grouped in another class; and so, as we go on discerning, discriminating, and classifying, we collect the materials of philosophy.

But this is not all of philosophy. Facts have genetic relations. If one thing is done something else will follow, and the highest function of scientific philosophy is to discover the order of succession of phenomena-how phenomena follow phenomena in endless procession, how every fact has had its antecedent fact, and every fact must have its consequent fact. This part of science is called evolution, and by this expression scientific men mean to be understood that phenomena go on in endless consequences, and that every act has been preceded by some other act, and that every act will be followed by some other act; that the causes of all of the phenomena of the universe that we wish to explain in a system of phil- 
osophy run back into the infinite past ; that the consequences of all of the phenomena which we may now observe in the universe will run on into the infinite future. This is evolution.

The statement now given of the three great systems of philosophy is, perhaps, sufficient for our purposes this evening, and it remains for us to point out the part contributed to scientific philosophy by Darwin, whom we mourn to-night.

When Darwin rose as a light in the scientific world, scientific philosophers had already discovered that the philosophic method of research should include the discernment, discrimination, and classification of facts. At that time the scientific men of the world were engaged chiefly in the collection and arrangement of facts. To some extent they were engaged in discovering their relations of sequence. Important and interesting sequences had been discovered in the vast realm of astronomy; other interesting sequences of facts had been discovered in the realm of geology; some interesting sequences of facts had been discovered in the realm of human history. In the realm of biology, in plant and animal life, the order of succession of facts, the method of evolution, had not been discovered; yet many men were thinking on the subject, many men searching for the method and course of biologic evolution. The facts relating thereto were partly known, and the course and laws of biologic evolution were dimly discerned.

It remained for Darwin to demonstrate the laws of biologic evolution, and the course of the progress 
(of life upon the globe. This he has done in a manner so masterly that there lives not in the world a working biologist, a scientific man engaged in this field of research, who has not, directly or indirectly, accepted his great conclusions, and the larger body of biologists have accepted them directly.

Let us now go back to the statement that, prior to the time of Darwin, scientific men engaged in researches relating to vegetal and animal life were occupied chiefly in the discernment, discrimination, and classification of facts.

Botanists and zoölogists were engaged in describing species, and classifying species, and this did not always enlist the highest talent; and naturalists had become wearied with discussions over minute differences and obscure resemblances, the origin and meaning of which were not understood.

The discovery, largely made by Darwin, of the laws of succession, or genesis, gave to this department of scientific research a wonderful impetus, and since that day thousands of men have sprung up throughout the civilised world to take part in biologic research.

In this field the greatest talent of the latest time is absorbed. The philosophy of biology satisfies the reason. In the universe of life, system is discovered, and biologists see visions of the origin of living beings, and dream dreams of the destiny of living beings.

Had philosophers discovered that the generations of living beings were degenerating, they would have discovered despair. Had they discovered that life 
moves by steps of generations in endless circlesthat what has been is, and what is shall be, and there is no progress, the gift of science to man would have been worthless.

The revelation of science is this: Every generation in life is a step in progress to a higher and fuller life; science has discovered hope.

Darwin demonstrated what others vaguely believed or dimly saw-the course and methods of biologic evolution. Darwin gave hope to philosophy.

The universe of phenomena may be classed in three great categories :

I. Physical.

II. Biologic.

III. Anthropologic.

Physical phenomena may be thrown into three categories: I. Molar or mechanical physics; 2. Stellar or astronomical physics ; 3 . Molecular physics.

Biologic phenomena may be classed as: 1. Vegetal ; 2. Animal.

Anthropologic phenomena may be classed as: I. Sociologic ; 2. Philologic; 3. Philosophic; 4, Psychologic.

To the discovery of the methods and course of physical evolution i.e. the order of succession in physical phenomena, many great men have contributed. Among these, Newton stands pre-eminent.

The discovery of biologic evolution, i.e., the succession of phenomena in vegetal and animal life, is in like manner due to the researches of many men, but among these Darwin stands pre-eminent. By his discoveries the discoveries of all other biologists 
have been correlated and woven into systematic philosophy. The methods and course of anthropologic evolution have yet to be systematised. Important discoveries have been made, but this portion of philosophy is yet inchoate.

\section{Working Hypotheses.}

But Darwin's investigations have not ended research or completed philosophy. He brought scientific men to the frontiers of truth, and showed them a path across the border. Yet more than this he did. He pointed out one of the fundamental methods of research. Before his time philosophers talked about deductive methods and inductive methods. Darwin has taught us that both are fruitless.

Deductive methods are the logical or metaphysical methods which have been already described, by which men arrive at conclusions from general principles supposed to be innate in the human mind. The vanity of these methods has already been characterised.

Inductive methods have found their best expression in the Baconian philosophy. By inductive methods men are to collect facts, unbiased by opinions or preconceived theories. They are to gather the facts, put them together, arrange and combine them to find higher and still higher generalisations.

But there are facts and facts-facts with value, and facts without value. The indiscriminate gathering of facts leads to no important discoveries. Men might devote themselves to counting the leaves on the trees, the blades of grass in the meadows, the 
grains of sand on the sea-shore;-they might weigh each one, and measure each one, and go on collecting such facts until libraries were filled, and the minds of men buried under their weight, and no addition would be made to philosophy thereby. There must be some method of selecting, some method of determining what facts are valuable and what facts are trivial. The fool collects facts; the wise man selects them.

Amid the multiplicity of facts in the universe, how does the wise man choose for his use? The true scientific man walks not at random through the world, making notes of what he sees; he chooses some narrow field of investigation. Within this field he reviews what is already known, and becomes conversant with the conclusions already reached. He then seeks to discern more facts in this field, and to make more careful discriminations therein, and then to make more homologic classifications; and, finally, more thoroughly to discover the complexity of sequences.

If he attain to success in doing all this his investigations are always suggested by some hypothesissome supposition of what he may discover. He may find that his hypothesis is wrong, and discover something else; but without an hypothesis he discovers nothing. A scientific man taking up a subject reviews the facts that are known, and imagines that they lead to conclusions that have not yet been reached by others. His imagination may lead him quite astray, yet he follows it, and says: "Now if this be true, then there must be certain yet undiscovered 
facts," and he seeks for them. He may find that which he seeks, or he may find something quite other. If he be an honest thinker, a true philosopher, it matters not to him. He substantiates his hypothesis or constructs a new one. If such hypothesis leads to many new discoveries scientific men accept it, and call it a working hypothesis, and if it still leads on to discovery scientific men call it a theory; and so working hypotheses are developed into theories, and these theories become the fundamental principles, the major propositions of science, the widest generalisations of philosophy.

Sometimes the inductive method-the Baconian method-is said to have been modified or improved by the addition of the method by working hypotheses, and then modern scientific methods are said to be inductive. With this understanding, it may be said that the deductive methods of metaphysics have been supplanted by the inductive methods of science. It would, perhaps, be better to say that deductive and inductive methods have been superseded by the method of working hypotheses.

Working hypotheses are the instruments with which scientific men select facts. By them, reason and imagination are conjoined, and all the powers of the mind employed in research.

Darwin, more than any other man, has taught the use of working hypotheses. Newton and Darwin are the two great lights of science-the Gemini in the heavens of philosophy; stars whose glory is the brightest of all.

There be good folk in the world who love mytho. 
logic and metaphysic philosophy-one or both. In the ears of such the praise of Darwin is not sweet music. Let me beg of such who may be here to consider that we come to-night to praise our dead, and to tell of our love for the man who gave us hope. You and I cannot contend over an open grave, and in my soul I find no cause for angry contention elsewhere. Every man's opinions are honest opinions-his opinions are the children of his own reasoning, and he loves his offspring.

When I stand before the sacred fire in an Indian village and listen to the red man's philosophy, no anger stirs my blood. I love him as one of my kind. He has a philosophy not unlike that of my forefathers, though widely separated from my own, and I love him as one near akin.

Among civilised men I find no one who has not a philosophy in part common with my own; and of those smaller portions of our philosophies which are not alike, I see no cause why anger should be kindled between us thereby. They and I are bound together by the same cord of honesty in opinion.

In Darwin's writings I find no word of reproach. Denunciation and ridicule, greater than any other man has endured, never kindled a spark of hatred in his breast. Wrapped in the mantle of his philosophy he received no wounds, but lived with and loved mankind,

Let us not gird science to our loins as the warrior buckles on his sword. Let us raise science aloft as the olive branch of peace and the emblem of hope. 
DARWIN'S WORK IN ENTOMOLOGY.

BY CHARLES V. RILEY, PH.D.,

Hon. Curator of Entomology, National Museum ; Entomologist of the Agricultural Department.

Charles Robert Darwin was one of the original members of the London Entomological Society, of whom only six are yet living. He always took the keenest interest in the science of entomology, and drew largely from insects for illustrations in support of the theory with which his name will forever be associated. Indeed, I have the authority of my late associate editor of the American Entomologist, Benjamin Dann Walsh, who was a classmate of Darwin's, at Cambridge, that the latter's love of natural history was chiefly manifested, while there, in a fine collection of insects; so that, as has been the case with so many noted naturalists, Darwin probably acquired from the study of insects that love of nature which first forever afterward inspired him in his endeavours to win her secrets and interpret aright her ways!

Though he has left no descriptive or systematic work of an entomological character, yet his writings abound in important facts and observations anent insects, and no branch of natural science has more fully felt the beneficial impulse and stimulus of his labors than entomology. Indeed, the varying conditions of life in the same individual or species; the remarkable metamorphoses; the rapid development ; the phenomena of dimorphism and heteromorphism; of phytophagic and sexual variation; the ready adaptation to changed conditions, and consequent 
rapid modification; the great prolificacy and immense number of individuals; the three distinctive states of larva, pupa, and imago, susceptible to modification, as well as other characteristics in insects-render them particularly attractive and useful to the evolutionist, and the changed aspect which natural history in general has assumed since the publication of the "Origin of Species" is perhaps more marked in entomology than in any other branch, for its author helped to replace ridicule by reason. During his voyage on the Beagle he collected a very large number of interesting species, especially in Coleoptera, and they formed the basis of many memoirs by Walker, Newman, and White, and particularly by G. R. Waterhouse, who named Odontoscelis Darwinii after him. These memoirs were published either in the Annals and Magazine of Natural History, and in the Transactions of the London Entomological Society, or in various entomological periodicals, and I append a list, which, in this connection, it is not necessary to read.

Scattered through his memorable works, a "Journal of Researches into the Natural History and Geology of the Countries Visited during the Voyage of H. M. S. Beagle round the World " (which is best known by the publisher's title, "A Naturalist's Voyage round the World"), and "The Origin of Species by Means of Natural Selection," are many interesting entomological facts, and in almost every instance they are illumined by his masterly genius and his keen, penetrating mind. These are so numerous, so varied, and withal so widely dispersed, 
that I can only make reference, at this time, to a few of the most important and striking of them.

He pointed out the great preponderance of phytophagous over predaceous species in the tropics as exemplifying the relation of the insect and plant worlds, both of which attain their maximum in those zones. Carabidae are few ; Scavengers and Brachely. tra very common; Rhynchophora and Chrysomelide astonishingly numerous. ("Journal of Researches," etc., p. 34.)

He showed by minute observations that the insect faunas of Tierra del Fuego, separated from Patagonia only by the Straits of Magellan, have nothing in common, and he discussed the influence of primary barriers on the distribution of species, as shown in the marked divergence of the faunas on the eastern and western slopes of the Cordillera. "We ought not," he remarks, "to expect any closer similarity between the organic beings on the opposite sides of great mountain ranges than on the opposite shores of the ocean, except for species which have been able to cross the barrier, whether of rock or salt water." (Ibid., pp. 326, 327.)

I believe he was the first to draw attention to the paucity of insects on islands, and to establish the principle that the smaller the area, the less favourable it is for the development of insect life. (Ibid., p. 39I.)

It is a fact of observation that islands predispose to the apterous condition among insects, a fact that is especially noticeable in Kerguelen's Land, as observed by Dr. Hooker, and particularly by our fellow member, Dr. Kidder. Darwin ("Origin of Species," 
etc., p. I09) first suggested the most plausible reason, viz. : that the indiscriminate use of wings might prove injurious to an insular species by tempting it out to sea and to destruction, so that the loss of the power of flight is a positive advantage to the species. - The argument against this explanation, viz.: that insular species should be gifted with strong powers of flight to fortify themselves against being blown to sea in heavy gales, has little force, because either requirement may be fulfilled; and, in reality, where flight is absolutely necessary, as in the majority of Lepidoptera, and flower-frequenting Coleoptera, the wing capacity, in insular species, is actually increased, or correlated with a diminution of bulk; whereas, in those less dependent on aërial progression, natural selection would decrease wing-power, and there would be just such a correlated increase of bulk as is generally the case.

The principle he laid down, that the accidental introduction of organic beings amongst others to whose interest they are hostile, may be a powerful means of keeping the latter in check, and of finally destroying them, finds vivid exemplification in insects, as I have shown in discussing those imported into this country.*

He gave reasons for the belief (now generally accepted) that the usual gaudy colouring of intertropical insects is not related either to the heat or light of those zones, but rather to the conditions of existence being generally favourable to life. ("Jour-

* "Second Annual Report on the Insects of Missouri,". 1879, pp. 8-13. 
nal of Researches," etc., p. 38r.) He has written on the phosphorescence of fire-flies, and on the habits of the larva of one of them-Lamphyris occidentalis. (Ibid., pp. 29, 30.) He discussed the foodhabits of stercovorous beetles, with reference to the origination of a new habit and the power of adaptation to new conditions. (Ibid., p. 490, note.)

At Port St. Julian, Patagonia, he found a species of Tabanus extremely common, and remarks: "We here have the puzzle that so frequently occurs in the case of mosquitoes-on the blood of what do these insects commonly feed? The guanaco is nearly the only warm-blooded quadruped, and is found in quite inconsiderable numbers compared with the multitude of flies." He has discussed the question of hibernation of insects, and shown that it is governed by the usual climate of a district, and not by absolute temperature. (Ibid., pp. 98, 99.) $\mathrm{He}$ gave the first true explanation of the springing power of the Elateride when laid on their backs, showing how much depended on the elasticity of the sternal spine. (Ibid., p. 3r.) He was the first, I believe, to record the exceptional powers of running and of making sound, in a butterfly, viz., Ageronia feronia of Brazil.

In his most famous work he lays stress particularly on the following facts and generalisations, for which he draws from insects: the individual differences in important characters; the remarkable manner in which individuals of the same brood often differ, dimorphism and trimorphism being only the extreme exaggeration of this fact; the difficulty of 
distinguishing between species and varieties; that geographical races are local forms completely fixed and isolated; that representative species are better distinguished from each other than local forms and sub-species; that the species of large genera vary more frequently than those of small genera, and that specific differences in the former are often exceedingly small ; that fecundity does not determine the rate of increase; that the struggle for life is most severe between species of the same genus; that secondary sexual characters are generally displayed in the same parts of the organisation in which the species of the same genus differ from each other; that distinct species present analogous variations; that similar structures are often independently developed; the varying importance for classification of the same important organ in the same group of beings; that analogical or adaptive resemblances are misleading for classification; that the great frequency of mimicry among insects is associated with their small size and general defencelessness, as no species furnished with a sting, or other defensive property, is known to mimic other species; the importance of relative position or connection in homologous parts; the remarkable changes of structure effected during development; that adaptation to the conditions of life in the insect larva is just as perfect and beautiful as in the adult animal, and that, consequently, larvæ of different orders are often similar, and larvæ belonging to the same order often very dissimilar; that larval and pupal stages are acquired through adaptation, 
and not through inheritance; that rudimentary organs plainly declare their origin and meaning.

Finally he brought together a large body of interesting facts in entomology, bearing on the development and perpetuation of mimicry, and of secondary sexual characters-all more or less explicable by, and furnishing convincing argument for, the general theory of natural selection; while he freely acknowledged that he found among insects facts that seemed to be most fatal to the theory. This is especially the case in social insects where the colony contains neuters and sterile females which often differ widely in instinct and in structure from the sexual forms, and yet cannot propagate their kind. This is not the place to enter into a diseussion of the subject, and I will simply remark that there are reasons for the belief that, in his candour, he has been led to exaggerate the difficulties in this case.

But Darwin's chief investigations into insect life were in its relations to plant life, and his work "On the Various Contrivances by Which British and Foreign Orchids are Fertilized by Insects, and on the Good Effect of Crossing," as also that on "Insectivorous Plants," are monuments of skill, industry, and lucid exposition.

Entomologists had often noticed the pollen masses of orchids attached to the proboscis of various moths, and in commenting upon the fact had pronounced it "curious." Darwin in this, as in so many other cases, gave meaning to the curious, and brought light out of darkness. 
Before his time we find frequent reference to the injury caused to plants by insects, and Sprengel, Gaertner, Herbert, and others had shown that insects were also, in many cases, beneficial and even necessary to plants ; the color, form, odor, secretions, and general structure of which have reference to their necessary insect pollinisers.

Yet their writings had produced but slight impression outside of a limited circle. It remained for Darwin to impress the world with a broader sense of the actual interrelation between the two, and to inspire a number of observers in this field in all parts of the globe, who are now constantly adding to the rich store of facts we already possess on the subject. I need only refer to the work of Hooker, Bennet, Axell, Delpino, Hildebrand, H. Müller, and others abroad, and to that of Dr. Gray and Mr. Wm. Trelease at home.

The importance of insects as agents in cross-fertilisation, was never properly appreciated till after Darwin's remarkable work on Primula and his researches on Orchids, Linum, Lythrum, etc.

He established the principle that "nature abhors close fertilization," and though some less careful observers in this country-exaggerating the importance of their isolated and often inaccurate observations-have opposed his views, the scientific world has been convinced alike by the force of his logic as by the eloquence of his innumerable facts.

We all know how palæontology has verified many of his anticipations as to missing links being supplied with increased knowledge of the geological record, 
and in connection with his work on the fertilisation of orchids we have a remarkable instance of similar verification. The nectaries of Angracum sesquipedale were found by him to sometimes reach I I $\frac{1}{2}$ inches in length, with only the lowest $\mathrm{I} \frac{1}{2}$ inches filled with nectar. He said "there must be moths with probosces capable of extension to a length of between IO and II inches." In Nature for July I7, I873, or some years later, Fritz Müller recorded through his brother, Herman Müller, the finding of a Brazilian Sphingid having a length of proboscis of 0.25 metres, or between $\mathrm{IO}$ and II inches.

I cannot do justice to Darwin's work on "Insectivorous Plants" within the time to which these remarks have been limited, nor without trenching on the ground to be covered by Professor Ward. I must be content to remark, therefore, that he demonstrated the new and wonderful fact in physiology that many plants are capable of absorbing soluble matter from captured insects, and that they have special contrivances and sensibilities that facilitate the capture of their prey: in other words, that plants actually capture and digest animal food; for the secretion of Drosera, and other insectivorous plants, with its ferment-acid belonging to the acetic series, resembles the gastric juice of animals with its pepsin and hydrochloric acid. The fact of absorption demonstrated, it follows that the process would prove serviceable to plants growing in very poor soil, and that it would tend to be perfected by natural selection.

The pleasure Darwin took in observing the hab- 
its and ways of insects and the simple and lucid manner in which he recorded his observations are frequently exemplified in his "Journal of Researches," and his account of sundry Brazilian species on page 35 , and following, may be consulted as an example.

In the same way that he has influenced all lines of thought and investigation, he has influenced entomology. We find everywhere in his treatment of insects the same acute perception, the same candour and impartiality, the same clearness of expression, the same aptitude to get at the significance and bearing of facts observed, as well as the same readiness to deduce a theory, which is only equalled by the devotion with which he clings to the truth, whether favourable or unfavourable to the theory.

In the light of Darwinism, insect structure and habit have come to possess a new significance and a deeper meaning. It has, in short, proved a new power to the working entomologist who, for all time, will hold in reverence the name of him who, more than any other man, helped to replace scholasticism by induction, and who gave to the philosophic study of insects as great an impetus as did Linnæus to their systematic study.

In his private life Darwin has given us a lesson of patience, courtesy, and consideration, that will be best appreciated by those who have the misfortune to be endowed with more irritable and aggressive natures.

As the above account of Darwin's entomological work is doubtless rather uninteresting to most of those gathered here, I will close, by request, with a few personal impressions. 
I have had the pleasure, on two occasions, of visiting Darwin at his invitation. On the first occasion, in the summer of $187 \mathrm{I}$, I was accompanied by Mr. J. Jenner Wier, one of his life-long friends and admirers. From Mr. Wier I first learned that Darwin was, in one sense, virtually a confirmed invalid, and that his work had been done under physical difficulties which would have rendered most men of independent means vapid, self-indulgent, and useless members of society.

It is eloquent of the indomitable will and perseverance of the man that, during the long voyage on the Beagle, he suffered so from sea-sickness that he never fully recovered from the shock to his system, and could not again venture on the ocean. He had, in fact, on his return from the voyage, to go through a long course of hydropathic treatment. We also now know that though he had suffered much for some months past from weakness and recurring fits of faintness, and had been confined to the house, yet as late as Tuesday evening before the day of his death, at 4 P.M., Wednesday, he was in his study examining a plant which he had had brought to him, and that he read that night before retiring, while as late as the I6th of March, he read two papers on special botanical subjects before the Linnæan Society.

The village of Down is fifteen miles south-east of London, four miles from Orpington station on the South-Eastern Railway. The country is among the most beautiful agricultural suburbs of London, and I shall never forget the impression of peaceful, quiet seclusion experienced, as we drove from the station 
and finally through one of those characteristic English lanes, just wide enough for one vehicle, and worn down several feet below the general level-the sense of confinement being enhanced by the luxuriant hedge on either side. This lane skirts the orchard wall for one hundred yards and then goes in front of the house, from which it is separated by a grass plot and flint wall overgrown with ivy.

The Darwin residence is a plain, but spacious, oldfashioned house of the style so common in England, and which, with the surrounding well-kept grounds and conservatory, conveys that impression of ease and comfort that belong to the average home of the English country-gentleman. A noticeable feature is a bow window extending through three stories and covered with trellis and creepers. In Darwinian phrase, the environment was favourable for just such calm study and concentration as he found necessary to his health and his researches.

Upon introduction I was at once struck with his stature (which was much above the average, and I should say fully six feet), his ponderous brow, and long white beard - the moustache being cut on a line with the lips and slightly brown from the habit of snuff-taking. His deep-set eyes were light blue-gray.

He made the impression of a powerful man reduced somewhat by sickness. The massive brow and forehead show in his later photographs, but not so conspicuously as in a life-size head of him when younger, which hung in the parlour.

In the brief hours I then spent at Down the proverbial modesty and singular simplicity and sweet. 
ness of his character were apparent, while the delight he manifested in stating facts of interest was excelled only by the eagerness with which he sought them from others, whether while strolling through the greenhouse or sitting round the generously spread table.

Going to him as a young entomologist with no claim on his favour, he seemed to take delight in manifesting appreciation. I had occasion, in my "Third Report on the Insects of Missouri," published in the spring of that year, to discuss the question of natural selection in its bearings on mimicry, as exemplified in two of our North American butterflies (Danais archippus and Limenitis disippus). This report I found in his study with many leaves turned down, and he appeared to take especial pleasure in conveying a sense of his appreciation of particular parts.

The few letters which I received from Darwin were in his own handwriting, which was rapid and better calculated to save time than to facilitate the reading. I take the liberty of reproducing here the first and last as indicating his attitude toward all workers in the field of natural science, however humble or however undeserving of his praise they may have been ; and this generous trait in his character will explain, in some measure, the stimulus and encouragement which he gave to investigators:

JUNE I, [1871.]

Down, BECKENHAM, KeNT.

My Dear Sir: I received some little time ago your "Report on Noxious Insects," and have now read the whole with the greatest interest. There is a vast number of facts and generalisations of value 
to me, and I am struck with admiration at your power of observation. The discussion on mimetic insects seems to me particularly good and original. Pray accept my cordial thanks for the instruction and interest which $I$ have received.

What a loss to natural science our poor mutual friend, Walsh, has been: it is a loss ever to be deplored.

Pray believe me, with much respect,

\section{Yours, very faithfully,}

CH. DARWIN.

SEPTEMBER 28, 188 r.

Down, BECKENHAM, KeNT.

My Dear Mr. RiLey : I must write half-a-dozen lines to say how much interested I have been by your "Further Notes" on Pronuba, which you were so kind as to send me. I had read the various criticisms, and though I did not know what answer would be made, yet I felt full of confidence in the result, and now I see I was right.

If you make any further observation on Pronuba it would, I think, be well worth while for you to observe whether the moth can or does occasionally bring pollen from one plant to the stigma of a distinct one; for I have shown that the cross-fertilisation of the flowers on the same plant does very little good, and, if I am not mistaken, you believe that the Pronuba gathers pollen from the same flower which she fertilises.*

* This is a misapprehension. Pronuba is an effectual cross-fertiliser, running from flower to flower, and often flying from raceme to raceme with one and the same load of pollen. The omitted passages in this letter refer to the work of a gentleman still living. 
What interesting and beautiful observations you have made on the metamorphoses of the grasshopperdestroying insects!

Believe me, my dear sir,

\section{Yours sincerely,}

CH. DARWIN.

My own experience in this regard is the common experience, for an interest in natural science was an open sesame to his generous soul. His consideration, without aggression, was the secret of the gratitude and respect which all felt who had the honour to know him, either personally or through correspondence.

His approval of the work of others was coupled with a depreciation of his own, which was very marked on the occasion of my second visit to Europe, in 1875 , when I crossed the ocean with his son Leonard on his way from the Transit of Venus expedition. "Insectivorous Plants" was just finished, and Darwin was worn and in feeble health, staying, in fact, at Abinger Hall for rest. He was quite disgusted with the book, to use his son's expression, and doubted whether it could prove of sufficient interest, with its long and dry records of experiments, to be read by anyone.

\section{DARWIN AS A BOTANIST.}

BY LESTER F. WARD, A.M., LL.D.,

Hon. Curator Department of Fossil Plants, U. S. National Museum; Paleobotanist U. S. Geological Survey.

Appointed by the committee to furnish a brief sketch on this occasion of the contributions of 
Charles Darwin to the science of plants, I have purposely chosen the title, "Darwin as a Botanist," in order to emphasise the contrast which may be drawn between different classes of botanists, and to do what I can to accustom the public mind to associate with the terms botanist and botany certain great fields of investigation which are now rarely suggested by these words.

If I had entitled my paper: Darwin's researches into the phenomena of the vegetable kingdom, I fear it might not have occurred to some of you that this great investigator was a botanist, as he is not generally known as such. Yet I fail to see why the science of botany is not fully entitled to receive its share of the dignity and the lustre which Darwin's investigations have reflected upon biology in general.

The popular idea of botany, however, is very different from this. Not ignorant people alone, but scientific men as well, place all botanists under two general classes: "field botanists" and " closet botanists."

The field botanist is one who, being passionately fond of plants, and having mastered the rudiments of botany and become familiar with the names and classification of plants, searches the country for new and rare species, and for new localities for old ones, and makes large collections. Success in these objects is his triumph, and occasionally becoming the proud discoverer of hitherto unknown forms of vegetable life, he finds the scientific world quick and generous in awarding him due credit.

The closet botanist is one who, disdaining the 
boyish pursuit of flowers, devotes himself to the study of the characters of plants as revealed by the herbarium specimens which the field botanist so copiously furnishes, and by which method he, too, can discover " new species," and obtain prompt recognition. The closet botanist performs the further useful service of "revising" intricate families and genera of plants, unravelling the entanglements of previous authors, and making such changes in the classification and names as are best suited to secure the maximum personal credit.

I need not tell this audience that Charles Darwin belonged to neither of these classes of botanists. A lover of nature, he yet never wasted precious time in the idle pursuit of rarities. Thoroughly familiar with the distinctive characters upon which botanical classification rests, he yet never pursued to any marked extent the investigation of specimens from the hortus siccus. I doubt whether a single species of plant was ever named after him by reason of his having either discovered it in a wild state or detected its specific distinctness by the examination of its characters. I even doubt whether he possessed an herbarium in the accepted sense of the word.

And yet this man has probably contributed more to our real knowledge of plants than any other single botanist.

In what, then, have Darwin's botanical investigations consisted?

There is a little French book entitled "Voyage d'un Botaniste dans sa Maison," a title which, allowing for the characteristic hyperbole of the French 
tongue, suggests the general nature of Darwin's botanical studies. His researches were conducted in his laboratory, in pots of plants at his window, in his aquarium, in his greenhouse, in his garden. He worked with instruments of precision, recorded his observations with exactness, and employed every mechanical device for making his results reveal important truths of which the genius of man would seem to be capable.

Darwin looked upon plants as living things. $\mathrm{He}$ did not study their forms so much as their actions. He interrogated them to learn what they were doing.

The central truth, towards which his botanical investigations constantly tended, was that of the universal activity of the vegetable kingdom-that all plants move and act. He has, so to speak, animated the vegetable world. He has shown that whichever kingdom of organic nature we contemplate, to live is to move.

He blandly rebukes the vulgar notion that "plants are distinguished from animals by not having the power of movement," and still more modestly says that "plants acquire and display this power only when it is of some advantage to them." But is this the whole? Do animals display this power except when it is of some advantage to them? Certainly not.

Darwin shows us that certain parts of all plants are at all times in motion; not merely the molecular activities of their tissues and of the living protoplasm in their cells, but organised movement of parts. Every leaf, every tendril, every rootlet, pos- 
sesses the power of spontaneous movement, and under nearly all circumstances actually exercises that power.

There are a great many distinct kinds of movement, depending in all cases upon the special advantages thereby gained to the plant. The laws under which these movements take place have received from him an admirable terminology. Most of them are conditioned either by light, by gravity, by radiation, or by insect agency.

We thus have of the first class: heliotropism, or movement towards the light; apheliotropism, or movement from the light ; diaheliotropism, or movement at right angles to the source of light; and paraheliotropism, embracing such movements as screen the plant from excess of light.

To the second class belong: geotropism, or movement towards the earth or into the soil; apogeotropism, or movement contrary to the force of gravity; and diageotropism, or movement at right angles to the force of gravity.

The third class embraces the so-called nyctotropic movements of plants by which they appear to sleep, and which prove to be devices for the prevention of excessive radiation of the plants' heat.

Under the fourth class fall all those wonderful movements which aid the plant in preventing selfand securing cross-fertilisation, a subject of the most absorbing interest, and of which you have already listened to so able a presentation by Professor Riley from the point of view of the entomologist.

But Darwin's great service has been to show that 
these varieties of activity are simply modes in which inherent and spontaneous activities manifest themselves under these varying external influences.

His preliminary investigations into the nature of these innate powers of movement were directed to that large class of plants known as twiners and climbers, whose revolving motions were so thoroughly described in his work on "Climbing Plants." It was here that he laid the foundation for those later studies which eventually resulted in that great work, almost his last, on the "Power of Movement in Plants." In this work he demonstrates by an enormous induction that the ample sweeps of the twining plant are but the most obvious manifestations of a class of phenomena which are common to the entire vegetable kingdom.

Amid the varied forms of movement which plants present, Darwin has succeeded in finding one fundamental and generic one to which every other may be referred. To this universal form of plant activity he gives the name "circumnutation." Not only twining stems and tendrils, but parts of flowers, tips of growing shoots, caps of penetrating roots and rootlets, radicles, epicotyls, cotyledons, and even full-grown leaves, are incessantly describing circles, ellipses, and other more or less regular geometrical figures; and he conclusively shows that it is out of this primary form of activity that all the more specialised forms already mentioned have been developed. All movements of the parts of plants are thus to be interpreted as modified forms of this innate periodic circumnutation which is common to 
all plant life. Such modifications are always in the direction of the plant's advantage, and may be so great as to become difficult of recognition as forms of circumnutation.

I need not labour to convince you that any modification which is an advantage to the plant will be secured by the process of natural selection. It is the glory of the great genius whose labours we are here to commemorate to have demonstrated this truth to the entire satisfaction of the united scientific world.

Darwin has actually solved the great problem of phytolngy, so long supposed to be incapable of solution, viz.: Why does the root grow downward and the stem upward? Briefly and roughly stated, the answer to this question is that, as the bursting seed pushes out its two germinal points these circumnutate from the first, and thus explore their surroundings for the means of benefiting the plant. To employ Darwin's own word, they "perceive" the advantage that would result from the penetration of the soil on the one hand, and from the ascent into the free air and sunlight on the other, and through the pre-Darwinian law of the "physiological division of labour," the one becomes geotropic and the other heliotropic - the one develops into a radicle and then into a root, while the other develops into an epicotyl and then into a stem.

I will only add to the thoughts already presented, that Darwin's discovery of the existence in all plants of an innate and spontaneous mobility belonging to them as forms of organic life possesses an important ulterior significance. 
The law of natural selection, as a fundamental process, has long since passed the stage of discussion. But there has always remained one unsettled question lying at its very base, which Darwin himself admitted to be an open one. That question concerns the cause itself of variation. It is granted that, admitting the tendency to vary, all the results claimed for natural selection must follow; but many declare that, in this very tendency to vary, there is a mystery as great as the mystery of life itself.

It is only in this work on the "Power of Movement in Plants" that Darwin has really assailed this last fortress of supernaturalism. Not that he has avowed any such purpose, for of this he would have been incapable, but so skilfully and so powerfully has he marshalled the facts that the conclusion follows without being stated. No one can doubt that he perceived this, and I, for one, am convinced that he saw it from afar, and that it was the great end of his labours; but with his characteristic wisdom he has declined to invoke the odium theologicum, correctly judging that the truth must ultimately assert itself.

The tendency to vary, then, is a mechanical result of the proved fact of universal movement coupled with the admitted law of natural selection. By means of the former all plants and growing parts of plants are perpetually exploring their immediate surroundings in search, as it were, for conditions favourable to development. By means of the latter they are able to avail themselves of such favourable conditions when found. Nothing further than this is required to complete the natural explanation of all 
the phenomena presented by the organic world, and thus, at last, the whole domain of biology is emancipated from teleological fetters, and placed on the high plane of rational investigation.

In conclusion, let me simply say that, while we can but deeply mourn the irreparable loss which science has sustained in the death of Charles Darwin, we have still the highest grounds for congratulation in the fact that he lived to complete that great work which, next to the "Origin of Species," will, I firmly believe, be awarded by posterity the highest place, viz.: "The Power of Movement in Plants"; for, while the former auspiciously opened the great debate by stating the profoundest of all biological problems, the latter has fittingly closed the argument by answering the last objection.

\section{DARWIN ON THE EXPRESSION OF THE EMOTIONS.}

BY FRANK BAKER, M.D.

From the tendency of the imagination to magnify the unknown and remote, arises a popular error that to attain eminence a man of science must be able to gather facts from great distances-from the sources of the Nile, and from polar snows. But the near and commonplace are subject to the same laws as the atoms of interstellar space, and true scientific insight may discover in the very dust under our feet secrets hitherto concealed.

Darwin's work upon the "Expression of the Emotions" is continuous with and supplementary to his larger and better-known treatise on the "Descent of 
Man." As with other matter bearing directly upon the development hypothesis, its publication was deferred as long as possible, in order that the evidence might be fully weighed. Projected in 1838 , it was not published until thirty-five years later. One class of objections to the hypothesis was not considered in the main work. It was generally held that, by his emotional expression, man was widely separated from the lower animals. The eminent anatomist, Duchenne, who remains to-day the best authority on * muscular movements, merely expressed the views of the time when he stated that no cause could be assigned for facial expression, except the "divine fantasy" of the Great Artificer.

Having projected his work, how does Darwin proceed? From the gentlemen who have preceded me you have learned of his methods. To test the truth of his conceptions he commences a series of most minute and careful observations, amitting nothing within his reach. His most important field is that which is nearest; his own children, his friends and companions, even the dogs that accompany his daily walks, come under that powerful scrutiny. Where, indeed, can we find so perfect an observer? The calm sanity of his mind keeps him equally aloof from egotism and from self-depreciation. A fact is a fact, to be stated with the fairness and openness of perfect daylight. Here is a man who cares more for the truth than for himself. The black spot in man's sunshine, the shadow of himself, seems non-existent for him. He stands by his work, that is enough; if it has worth, well-if not, still well; the elemental 
drift of action and reaction will continue, the outcome will still be good. As Carlyle has said, "A noble unconsciousness is in him. He does not engrave truth on his watch-seal; no, but he stands by truth, speaks by it, works and lives by it."

But not as a fact gatherer do we find him greatest. Many others have struggled with ant-like toil to amass piles of facts which, like the ant-heap, remain but sand after all. Darwin brings to his work an informing spirit, the genius of scientific hypothesis. Breathed upon by this spirit, the dry bones of fact come together "bone to his bone," the sinews and the flesh come upon them, they become alive and stand upon their feet "an exceeding great army." He searches always for the principles which underlie the facts and make them possible, realising that the phenomena, the things which are seen, are temporal and transitory; the things which are not seen, the cosmical forces which govern and control, are eternal.

In his examination of the expression of the emotions he found that both in man and animals they can be referred to three general principles which may be termed habit, antithesis, and nervous overflow. By habit, or repetition, serviceable movements become fixed-involuntary, or semi-voluntary. By antithesis, opposite frames of mind are expressed by opposite actions, even though those actions may not be serviceable. The theory of nervous overflow is that unusual quantities of force generated by the cerebro-spinal system are discharged by unusual channels of expression when the ordinary channels are insufficient. 
He finds that emotional expressions are generally direct consequences of anatomical structure, and clearly shows the interdependence of anatomy and physiology. For structure can no more be divorced from function than matter can be dissociated from force. All the complex expressions of grief-from the twitching of the eyelids and mouth to the shedding of tears-he has shown to depend upon the necessity for preventing engorgement of the eyes during screaming, an act originally useful solely to attract attention. The steps by which he arrived at this conclusion are typical of his method. Starting first with animals, he finds that their expressions of grief are much less complex and various than those of man. They are confined to noises, such as screaming, barking, whining, in higher forms accompanied by changes in facial expression, particularly by contraction of the muscles surrounding the eye. There is a physiological necessity for this, as otherwise the expiratory effort caused by screaming might engorge and rupture the small ocular blood-vessels. By pressing on the lachrymal gland this causes, in some of the higher animals, a flow of tears. What at first was accidental, merely occasioned by the proximity of the gland, becomes at last habitual, and the nervous force automatically follows the line of its accustomed action, causing a flow of tears after emotional excitement, even though no screaming take place, The correctness of this view is supported by the fact that infants do not shed tears until several weeks old, although they scream violently. The functional activity of the lachrymal gland, in connection with 
grief, is, therefore, later in phylogenetic development. The laws of heredity and adaptation are found to be operating here, as elsewhere, in the domain of life; the supposed gap between the emotions of man and of other animals is successfully bridged over, and another anthropocentric fallacy is consigned to the limbo of ignorant superstitions.

Many expressions of the lower emotions are found to be disfiguring vestiges of acts useful to lower animals for offence and defence, or for obtaining food. - These survive-relics of the previous history of our race-as rudimentary organs are preserved long after their use has ceased. The erection of the hair during fear is remotely derived from the same cause that makes puss bristle when attacked and the puff adder swell out when approached. Originally used for the purpose of exciting fear in an enemy by an increase of size, it now involuntarily accompanies the somewhat changed emotion of which some of the phases are extinct. It is not very rare to find persons who can make the hair over the front of the head bristle at will. Rage is habitually expressed by uncovering the teeth, which is, in the lower animals, an attempt to frighten their enemies by a show of weapons. This expression may become softened and modified to express the milder emotions of contempt and disdain. I have met a lady who has to perfection the rather rare accomplishment mentioned by Darwin of drawing up the upper lip in a triangular notch directly over the canine teeth so as to display them alone, usually on one side at a time. This most expressive gesture of disdain can be per- 
formed under the influence of the emotions by many who cannot do it at will.

Of an opposite class are certain higher expressions, which, having arisen later, are not yet entirely fixed. Blushing is one of the most curious of these. It is not found in infants, and varies greatly in frequency and amount in adults, accompanying the sentiment of modesty, almost unknown among animals. The reddening is usually confined to the face and neck. Darwin suggests an ingenious explanation for this. The blood-vessels most exposed to variations of temperature acquire the habit of expanding and contracting-their vaso-motor nerves become more sensitive. The chief expression of personal appearance is in the face; the attention of the mind is, therefore, directed there whenever the emotion of modesty is aroused. This interferes with the ordinary tonic contraction of the blood-vessels, and an excess of blood suffuses the surface.

A remarkable confirmation of Darwin's views is the recent discovery of localised centres in the brain which control emotional expression, and exist in animals as well as in man. It may some time be possible to read the currents and counter-currents of the brain by means of feature-play with a precision approaching that by which we estimate the force of a distant battery by the play of a galvanometer needle. Many phenomena of expression, which were obscure before this discovery, can now be satisfactorily explained. Among these are the phenom. ena of associated movements. It has been stated that the variety and complexity of the movements 
involved in the simple act of walking are such that it would be impossible ever to perform it were it necessary to think what had to be done, and weigh in the judgment the precise amount of force necessary to distribute to each muscle at each moment of the act. It is now known that the cerebral centres which control the separate muscles put in action are closely contiguous in the brain, and that they probably intercommunicate and excite each other in a definite manner, predetermined by habit and heredity. The conscious mind has only to set in motion the subordinate apparatus, when it goes on, and works out the problem with matchless skill, like the system of cogs and eccentrics that produce the intricate pattern in an engraver's lathe. All have noticed the uncouth manner in which children and untrained persons follow with lips and tongue the motions of their hands when using a tool of any kind. Darwin ascribes this to unconscious imitation, but it can be explained more strictly in accordance with his own principles. The facial muscles are actuated from a cerebral centre in close proximity to those which move the arms and hands. In the lower animals this is necessary, for the mouth is an organ of prehension, used in strict association with the fore-limbs in seizing prey, and in other acts. As this associated movement became strongly fixed by long habit, it survives with greai obstinacy, and though it has not been useful to the race since the historical period, we have yet to caution our children not to put their tongues out when they write.

My limit of time forces me to conclude this hasty and imperfect summary. The practical bearing of 
these views is not without importance. Physicians have always depended greatly upon emotional expression as a means of diagnosis. Unconsciously the face of the patient reveals his physical state. Yet too much has been left in the empirical borderland of science. Why a certain pathological state should be indicated by a definite combination of expressions has not always been clearly shown. To-day the whole subject is studied from the point of view of anatomy and physiology. No occult force is admitted, the correlative nerve-supply of muscles and the effect of excitation of nerve-centres are rationally investigated.

Aside from the great special value of the work, of what tremendous import to the race are Darwin's deductions! For he has shown us that our every thought and act mould our physical frames, and through them the generations yet unborn, either to beauty and grace, or to uncouth ugliness and deformity. As the struggle for existence filled the rocks with organisms forever extinct, because not for the highest use, so may we, too, fossilise and outgrow habits and desires of ignoble birth, ascending by the "power of leasts," by that wondrous calculus of nature, to purer and nobler existence. Darwin has taught us that the forces which, acting through countless cycles, have brought us up from formless slime, now remain in our hands to use for good or ill-

"That life is not as idle ore,

But iron dug from central gloom, And heated hot with burning fears, And dipt in baths of hissing tears, And battered with the shocks of doom For shape and use." 


\section{A DARWINIAN BIBLIOGRAPHY.}

BY FREDERICK W. TRUE, M.S.,

Librarian of the U.S. National Museum, and Curator of Department of Mammals.

The complete bibliography of Darwinism should contain, not alone the works which emanated from the busy brain and ready pen of Darwin himself, but the many other productions which these called into life. The acquiescences of friends, the objections of critics, the censures of foes, should all be enrolled in their proper places as representing the ripples and counter-ripples in the sea of thought, produced by the weighty ideas which dropped from the clear mind of the philosopher. It is not to the merits of these, however, that I can call your attention, but only to a few facts relative to the books of Darwin himself.

I would not have you suppose, if indeed one could, after the lucid remarks to which you have listened, that the faulty-and, I fear, almost indiscernible-list of published works, which I have attempted to exhibit before you, reveals more than a moiety of Darwin's writings.* A large number of comprehensive papers, pregnant notes, and incisive queries are contained in those storehouses of precise knowledge, the journals of science, and the publications of learned societies. During more than half a century, from the beginning of Darwin's career to its very close, scarcely a year passed in which a

* The speaker referred to two large scrolls hanging on the lectureroom walls, upon which were inscribed a list of Darwin's most important publications. 
number of articles did not issue from his pen. His first paper, on the Ova of Flustra, and another of similar nature were read before the Plinian Society of Edinburgh in 1825. His last note, on the Distribution of Fresh-Water Bivalves, appeared in $\mathrm{Na}$ ture but a few days before his death.

During the first twenty-five years the articles have mostly a geological and zoölogical bearing, but later botanical and anthropological subjects come into prominence. They were contributed to many publications, including a few American, German, and French journals. The mass of papers, however, are to be found in the Proceedings and Transactions of the Geological Society of London, the Philosophical Transactions, the Philosophical Magazine, the Annals and Magazine of Natural History, and Nature.

It is in these papers that we first find the germs of many of those more elaborate works to which general attention has been attracted. Thus the works on the "Origin of Species," the "Fertilisation of Plants by Insects," the "Action of EarthWorms," and others, were foreshadowed at a time considerably antedating their final appearance.

Darwin seemed to prefer to work out and write out his ideas alone. Once at least, however, he shared the toil with his friend, Mr. Wallace, and later, in several instances, with his sons Francis and George Darwin.

Regarding the separately published works of Darwin there is much of interest from the bibliographical point of view. The conscientiousness with which 
the author profited by the criticisms of others, revising, improving, and extending his generalisations, makes each new edition seem like a separate production. Whole chapters were stricken out and new ones inserted; facts of doubtful character were replaced by others of a more positive nature and more recent acquisition.

Time forbids that I should refer to the details of publication of more than one work. The inquiring student will find his wants satisfied in the several lists which have already been published.

I will give the history of but one work, the most important of all, the "Origin of Species by Means of Natural Selection." The first edition of this work received the signature of the author on November 24, 1859, and was published the same year. The second edition, which appeared soon after, "was little more than a reprint of the first." "The third edition was largely corrected and added to, and the fourth and fifth still more largely." The sixth edition, which appeared in 1872, was likewise largely amended, and had reached its twenty thousand in 1878. In the meantime foreign editions and translations began to appear. The American and French editions at first kept pace with the English, the second American being from the second English, and the third French from the third English. The Germans, coming in a little later, published their second edition from the third English, and their third from the fourth English one. The last editions in all these languages were derived, I believe, from the sixth English one. "The Italian is from the third, 
the Dutch and three Russian editions from the second English editions, and the Swedish from the fifth English edition."

At least twelve of the more important works have been issued in one or more editions in German and French, and a number in other European languages as well.

The sage of Down was undoubtedly honest in his surprise at the ever-extending circle of his influence. A wider and more intelligent audience could scarcely be desired. The number of books in which his opinions are discussed or alluded to is legion. As the illustrious Asa Gray has remarked: "Dante literature and Shakespeare literature have been the growth of centuries, but Darwinism filled teeming catalogues during the lifetime of the author."

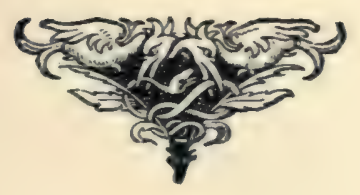





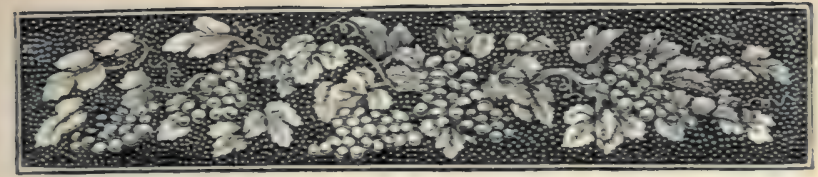

\section{APPENDIX.}

\section{LIST OF WORKS BY CHARLES DARWIN.}

Narrative of the Surveying Voyages of her Majesty's Ships Advenlure and Beagle between the years 1826 and 1836 , describing their examination of the southern shores of South America, and the Beagle's circumnavigation of the globe. Vol. iii., Journal and Remarks, 1832-36. By Charles Darwin. 8vo. London, I839.

Journal of Researches into the Natural IIistory and Geology of the countries visited during the voyage of H. M. S. Beagle round the world, under the command of Capt. Fitz-Roy, R. N. 2d edition, corrected, with additions. 8vo. London, r845. (Colonial and Home Library.)

A Naturalist's Voyage. Journal of Researches, etc. 8vo. London, 1860. [Contains a postscript dated Feb. I, I860.]

Zoölogy of the Voyage of H. M. S. Beagle. Edited and superintended by Charles Darwin. Part I., Fossil Mammalia, by Richard Owen. With a Geological Introduction, by Charles Darwin. 4to. London, 1840 .

Zoölogy of the Voyage of H. M. S. Beagle. Part II., Mammalia, by George R. Waterhouse. With a Notice of their Habits and Ranges, by Charles Darwin. 4to. London, 1839.

Zoölogy of the Voyage of H. M. S. Beagle. Part III., Birds, by John Gould. An "Advertisement" (2 pp.) states that, in consequence of Mr. Gould's having left England for Australia, many descriptions were supplied by Mr. G. R. Gray of the British Museum. 4to. London, I84I.

Zoölogy of the Voyage of H. M. S. Beagle. Part IV., Fish, by Rev. Leonard Jenyns. 4to. London, I842. 
Zoölogy of the Voyage of H. M. S. Beagle. Part V., Reptiles, by Thomas Bell. 4to. London, 1843 .

The Structure and Distribution of Coral Reefs. Being the First Part of the Geology of the Voyage of the Beagle. 8vo. London, 1842.

The Structure and Distribution of Coral Reefs. 2d edition. 8vo. London, 1874 .

Geological Observations on the Volcanic Islands visited during the Voyage of H.M. S. Beagle. Being the Second Part of the Geology of the Voyage of the Beagle. 8vo. London, 1844.

Geological Observations on South America. Being the Third Part of the Geology of the Voyage of the Beagle. 8vo. London, 1846.

Geological Observations on the Volcanic Islands and parts of South America visited during the Voyage of H. M. S. Beagle. 2d edition. 8vo. London, 1876 .

A Monograph of the Fossil Lepadidæ; or, Pedunculated Cirripedes of Great Britain. 4to. London, 1851. (Palæontographical Society.)

A Monograph of the Sub-class Cirripedia, with Figures of all the Species. The Lepadidæ; or, Pedunculated Cirripedes. 8vo. London, 1851. (Ray Society.)

A Monograph of the Sub-class Cirripedia, with Figures of all the Species. The Balanidx (or Sessile Cirripedes); the Verrucidæ, etc. 8vo. London, 1854. (Ray Society.)

A Monograph of the Fossil Balanidæ and Verrucidæ of Great Britain. 4to. London, 1854. (Palæontographical Society.)

On the Origin of Species by Means of Natural Selection, or the Preservation of Favoured Races in the Struggle for Life. 8vo. London, 1859. (Dated October I, I859, published November 24, I859.)

On the Origin of Species by means of Natural Selection, or the Preservation of Favoured Races in the Struggle for Life. Fifth thousand. 8vo. London, 1860 .

On the Origin of Species by Means of Natural Selection, or the Preservation of Favoured Races in the Struggle for Life. 3d edition, with additions and corrections. (Seventh thousand.) 8vo. London, 186r. (Dated March, I86r.)

On the Origin of Species by Means of Natural Selection, or the Preservation of Favoured Races in the Struggle for Life. 4th edition, with additions and corrections. (Eighth thousand.) 8vo. London 1866. (Dated June, 1866.) 
On the Origin of Species by Means of Natural Selection, or the Preservation of Favoured Races in the Struggle for Life. 5th edition, with additions and corrections. (Tenth thousand.) 8vo. London, 1869. (Dated May, 1869.)

On the Origin of Species by Means of Natural Selection, or the Preservation of Favoured Races in the Struggle for Life. 6th edition, with additions and corrections to 1872 . (Twenty-fourth thousand.) 8vo. London, I882. (Dated January, 1872.)

On the Various Contrivances by which Orchids are Fertilised by Insects. 8vo. London, 1862.

The Various Contrivances by which Orchids are Fertilised by Insects. 2d edition. 8vo. London, 1887. [In the second edition the word "On" is omitted from the title.]

The Movements and Habits of Climbing Plants. 2d edition. 8vo. London, 1875. [First appeared in the ninth volume of the Fournal of the Linnean Society.]

The Variation of Animals and Plants under Domestication. 2 vols. 8 vo. London, 1868.

The Variation of Animals and Plants under Domestication. 2d edition, revised. 2 vols. 8 vo. London, 1875.

The Descent of Man, and Selection in Relation to Sex. 2 vols. 8vo. London, 1871.

The Descent of Man, and Selection in Relation to Sex. 2d edition. 8vo. London, 1874. (In I vol.)

The Expression of the Emotions in Man and Animals. 8vo. London, 1872 .

Insectivorous Plants. 8vo. London, 1875.

The Effects of Cross- and Self-Fertilisation in the Vegetable Kingdom. 8vo. London, 1876 .

The Effects of Cross- and Self-Fertilisation in the Vegetable Kingdom. 2d edition. 8vo. London, 1878 .

The Different Forms of Flowers on Plants of the Same Species. 8vo. London, 1877 .

The Different Forms of Flowers on Plants of the Same Species. $2 d$ edition. 8vo. London, 1880.

The Power of Movement in Plants. By Charles Darwin, assisted by Francis Darwin. 8vo. London, 1880.

The Formation of Vegetable Mould, through the Action of Worms, with Observations on their Habits. 8vo. London, 188I. 


\section{LIST OF BOOKS CONTAINING CONTRIBUTIONS BY CHARLES DARWIN.}

A Manual of Scientific Enquiry; Prepared for the Use of Her Majesty's Navy ; and Adapted for Travellers in General. Ed. by Sir John F. W. Herschel, Bart. 8vo. London, r849. (Section VI. Geology. By Charles Darwin.)

Memoir of the Rev. John Stevens Henslow. By the Rev. Leonard Jenyns. 8vo. London, 1862. [In Chapter III., Recollections by C. Darwin.]

A letter (1876) on the "Drift" near Southampton, published in Prof. J. Geikie's "Prehistoric Europe."

Flowers and Their Unbidden Guests. By A. Kerner. With a Prefatory letter by Charles Darwin. The translation revised and edited by W. Ogle. 8 vo. London, 1878 .

Erasmus Darwin. By Ernst Krause. Translated from the German by W. S. Dallas. With a Preliminary Notice by Charles Darwin. 8vo. London, 1879.

Studies in the Theory of Descent. By Aug. Weismann. Translated and edited by Raphael Meldola. With a Prefatory Notice by Charles Darwin. 8vo. London, 1880-.

The Fertilisation of Flowers. By Hermann Maller. Translated and edited by D'Arcy W. Thompson. With a Preface by Charles Darwin. 8vo. London, 1883.

Mental Evolution in Animals. By G. J. Romanes. With a Posthumous Essay on Instinct by Charles Darwin, I883. [Also published in the fournal of the Linnaan Society.]

Some Notes on a curious habit of male humble bees were sent to Prof. Hermann Müller, of Lippstadt, who had permission from Mr. Darwin to make what use he pleased of them. After Müller's death the Notes were given by his son to Dr. E. Krause, who published them under the title, "Ueber die Wege der Hummel-Männchen" in his book, "Gesammelte kleinere Schriften von Charles Darwin "(I886).

\section{LIST OF SCIENTIFIC PAPERS, INCLUDING A SELEC-} TION OF LETTERS AND SHORT COMMUNICATIONS TO SCIENTIFIC JOURNALS.

Letters to Professor Henslow, read by him at the meeting of the Cambridge Philosophical Society, held Nov. r6, 1835. 31 pp. $8 \mathrm{vo}$. Privately printed for distribution among the members of the Society. 
Geological Notes Made During a Survey of the East and West Coasts of South America in the Years $I S_{32}, I S_{33}, I 3_{34}$, and $13_{35}$ : with an account of a transverse section of the Cordilleras of the Andes between Valparaiso and Mendoza. [Read Nov. IS. IS 35.] Geol. Soc. Proc., ii., IS 33 , pp. 2ro-212. [This Paper is incorrectly described in Geol. Soc. Proc., ii., p. 2ro, as follows: "Geological Notes, etc., by F. Darwin, Esq., of St. John's College, Cambridge : communicated by Prof. Sedgwick." It is Indexed under C. Darwin.]

Notes upon the Rhea Americana. Zoōl. Soc. Proc., Part V., 1837. Pp. 35, 36 .

Observations of Proofs of Recent Elevation on the Coast of Chili, Made During the Survey of H.M.S. Beagle, Commanded by Capt. Fitz-Ror. [1537.] Geol. Soc. Proc.. ii., 15335, pp. $46-449$.

A Sketch of the Deposits Containing Extinct Mammalia in the Jeighbourhood of the Plata. [1837.] Geol. Soc. Proc., ii., I838, Pp. 542-544

On Certain Areas of Elevation and Subsidence in the Pacific and Indian Oceans, as Deduced from the Study of Coral Formations. [1537.] Geol. Soc. Proc., ii., IS 38 , pp. 552-554

On the Formation of Mould. [Read Nor. I, 1837.] Geol. Soc. Proc., ii., 1533, pp. 574-576; Geol. Soc. Trans,, v., 1840, pp. 505-510.

On the Connexion of Certain Volcanic Phenomena and on the Formation of Mountain-chains and the Effects of Continental Elevations. [Read March 7, I533.] Geol. Soc. Proc., ii., I333, pp. 654-660; Geol. Soc. Trans., $5 ., 1340$, pp. 60I-632. [In the Society's Transactions the wording of the title is slightly different.]

Origin of Saliferous Deposits. Salt Lakes of Patagonia and La Plata. Geol. Sor. Fourn., ii. (Part II.), IS 33, pp. 127-123.

Note on a Rock Seen on an Iceberg in 16" South Latitude. Geogr. Sac. Fosern., ix., I539, pp. 528, 529 .

Observations on the Parallel Roads of Glen Roy, and of Other Parts of Lochaber in Scotland: with an attempt to prove that they are of marine origin. Phil. Trans.. I 3939. pp. 39-32.

On a Remarkable Bar of Sandstone off Pernambuco, on the Coast of Brazil. Phil. Mag., xir., IS41, Pp. 257-260.

On the Distribution of the Erratic Boulders and on the Contemporaneous Unstratified Deposits of South America. [I84I.] Geol. Soc. Proc., iii., IS 42 , pp. $425-430$; Geol. Soc. Trans., vi., I 842, pp. $415-452$. 
Notes on the Effects Produced by the Ancient Glaciers of Caernarvonshire, and on the Boulders Transported by Floating Ice. London Philosoph. Mag., vol. xxi., p. 180, 1842 .

Remarks on the Preceding Paper, in a Letter from Charles Darwin, Esq., to Mr. Maclaren. Edinb. Nero Phil. Fourn., xxxiv., 1843. pp. 47-50. [The "preceding" paper is : "On Coral Islands and Reefs as described by Mr. Darwin. By Charles Maclaren, Esq., F.R.S.E."]

Observations on the Structure and Propagation of the Genus Sagitta. Ann. and Mag. Nat. Hist., xiii., 1844, pp. I-6.

Brief Descriptions of several Terrestrial Planariæ, and of Some Remarkable Marine Species, with an Account of their Habits. Ann. and Mag. Nat. Hist., xiv., 1844, pp. 24I-25I.

An Account of the Fine Dust which often falls on Vessels in the Atlantic Ocean. Geol. Soc. Fourn., ii., 1846, pp. 26-30.

On the Geology of the Falkland Islands. Geol. Soc. Fourn., ii., I846, pp. 267-274.

A review of Waterhouse's "Natural History of the Mammalia." [Not signed.] Ann. and Mag. of Nat. Hist., 1847, vol. xix. p. 53.

On the Transportal of Erratic Boulders from a lower to a higher level. Geol. Soc. Fourn., iv., 1848, pp. 315-323.

On British Fossil Lepadidx. Geol. Soc. Fourn., vi., I850, pp. 439, 440. [The G.S. F. says: "This paper was withdrawn by the author with the permission of the Council."]

Analogy of the Structure of Some Volcanic Rocks with that of Glaciers. Edinb. Roy. Soc. Proc., ii., I85I, pp. I7, 18.

On the Power of Icebergs to Make Rectilinear, Uniformly-directed Grooves across a Submarine Undulatory Surface. Phil. Mag., x. I855, pp. 96-98.

Vitality of Seeds. Gardeners' Chronicle, Nov. 17, 1855, p. 758.

On the Action of Sea-water on the Germination of Seeds. [1856.] Linn. Soc. Fourn., i., 1857 (Botany), pp. 130-140.

On the Agency of Bees in the Fertilisation of Papilionaceous Flowers. Gardeners' Chronicle, p. 725, 1857.

On the Tendency of Species to Form Varieties; and on the Perpetuation of Varieties and Species by Natural Means of Selection. By Charles Darwin, Esq., F.R.S., F.L.S., and F.G.S., and Alfred Wallace, Esq. [Read July Ist, 1858.] Fourn. Linn. Soc., 1859, vol. iii. (Zoölogy), p. 45.

Special titles of C. Darwin's contributions to the foregoing: (i.) Extract from an Unpublished Work on Species by C. Darwin, Esq., con- 
sisting of a portion of a chapter entitled, On the Variation of Organic Beings in a State of Nature ; on the Natural Means of Selection; on the Comparison of Domestic Races and true Species. (ii.) $\mathrm{Ab}$ stract of a Letter from C. Darwin, Esq., to Professor Asa Gray, of Boston, U. S., dated Sept. 5, 1857 .

On the Agency of Bees in the Fertilisation of Papilionaceous Flowers, and on the Crossing of Kidney Beans. 'Gardeners' Chronicle. I858, p. 828, and Ann. Nat. Hist., 3d series, ii., 1858, pp. 459-465.

Do the Tineina or Other Small Moths Suck Flowers, and if so what Flowers? Entom. Weekly Intell., vol. viii., 1860, p. 103.

Note on the Achenia of Pumilio Argyrolepis. Gardeners' Chronicle, Jan. 5, 186r, p. 4 .

Fertilisation of Vincas. Gardeners' Chronicle, pp. 552, 831, 832, 186r.

On the Two Forms, or Dimorphic Condition, in the Species of Primula, and on their Remarkable Sexual Relations. Linn. Soc. Fourn., vi., 1862 (Botany), pp. 77-96.

On the Three Remarkable Sexual Forms of Catasetum tridentatum, an Orchid in the Possession of the Linnzan Society. Linn. Soc. Fourn., vi., 1862 (Botany), pp. 151-157.

Yellow Rain. Gardeners' Chronicle, July 18, 1863, p. 675.

On the Thickness of the Pampean Formation near Buenos Ayres, Geol. Sor. Fourn., xix., 1863, pp. 68-71.

On the So-called " Auditory-sac" of Cirripedes. Nat. Hist. Review, 1863, Pp. I15-116.

A Review of Mr. Bates' Paper on Mimetic Butterflies. Nat. Hist. Revieze, 1863, p. 221-. [Not signed.]

On the Existence of Two Forms, and on their Reciprocal Sexual Relation, in Several Species of the Genus Linum. Linn. Sor. Fourn., vii., 1864 (Botany), pp. 69-83.

On the Sexual Relations of the Three Forms of Lythrum salicaria. [1864.] Linn. Soc. Fourn., viii, 1865 (Botany), pp. 169-196.

On the Movement and Habits of Climbing Plants. [1865.] Linn. Soc. Fourn., ix., 1867 (Botany), pp. I-118.

Note on the Common Broom (Cytisus scoparius). [1866.] Linr. Sac. Fourn., ix., 1867 (Botanv), p. 358.

Notes on the Fertilisation of Orchids. Ann. and Mag. Nat. Hist., 4th series, iv., 1869, pp. 141-159.

On the Character and Hybrid-like Nature of the Offspring from the Illegitimate Unions of Dimorphic and Trimorphic Plants. [1868.] Linn. Soc. Fourn., X., I869 (Bolany), pp. 393-437. 
On the Specific Difference between Primula veris Brit. Fl. (var. officinalis, of Linn.), P. vulgaris, Brit. Fl. (var. acaulis, Linn.), and $P$. elatior, Jacq. ; and on the Hybrid Nature of the common Oxslip. With Supplementary Remarks on naturally produced Hybrids in the genus Verbascum. [1868.] Linn. Soc. Fourn., x., 1869 (Botany). pp. 437-454.

Note on the Habits of the Pampas Woodpecker (Colaptes campestris). Zoöl. Soc. Proc., Nov. 1, 1870, pp. 705, 706.

Fertilisation of Leschenaultia. Gardeners' Chronicle, p. II66, I87.

The Fertilisation of Winter-flowering Plants. Nature, Nov. 18, r869, vol. i., p. 85 .

Pangenesis. Nature, April 27, 1871, vol. iii., p. 502.

A New View of Darwinism. Nature, July 6, 1871, vol. iv., p. 180 .

Bree on Darwinism. Nature, Aug. 8, 1872, vol. vi., p. 279.

Inherited Instinct. Nature, Feb. 13, 1873, vol. vii., p. 281 .

Perception in the Lower Animals. Nature, March 13, 1873, vol. vii., p. 360 .

Origin of Certain Instincts. Nature, April 3, 1873, vol. vii., p. $4 \mathrm{I} 7$.

Habits of Ants. Nature, July 24, 1873, vol, viii., p. 244.

On the Males and Complemental Males of Certain Cirripedes, and on Rudimentary Structures. Nature, Sept. 25, 1873, vol. viii., p. 431.

Recent Researches on Termites and Honey-bees. Nature, Feb. I9, 1874, vol. ix., p. 308.

Fertilisation of the Fumariacex. Nature, April 16, 1874, vol. ix., p. 460 .

Flowers of the Primrose Destroyed by Birds. Nature, April 23, 1874, vol. ix., p. 482; May 14, 1874, vol. x., p. 24.

Cherry Blossoms. Nature, May 11, 1876, vol. xiv., p. 28.

Sexual Selection in Relation to Monkeys. Nature, Nov. 2, 1876, vol. xv., p. 18. Reprinted as a supplement to the "Descent of Man," I8-.

Fritz Muller on Flowers and Insects. Nature, Nov. 29, 1877, vol. xvii, p. 78 .

The Scarcity of Holly Berries and Bees. Gardeners' Chronicle, Jan. 20,1877, p. 83 . 
Note on Fertilisation of Plants. Gardeners' Chronicle, vol. vii., p. 246,1877 .

A Biographical Sketch of an Infant. Mind, No. 7, July, 1877.

Transplantation of Shells. Valure, May 30, 1878, vol, xviii., p. I20.

Fritz Muller on a Frog having Frers on its back-on the Abortion of the Hairs on the Legs of Certain Caddis-Flies, etc. Nature, March 20, 1879, vol. xix., p. 462.

Rats and Water-Casks. Nature, March 27, 1879, vol. xix., p. 481 .

Fertility of Hybrids from the Common and Chinese Goose. $\mathrm{Na}$ ture, Jan. 1, 1880, vol. xxi., p. 207.

The Sexual Colours of Certain Butterflies. Nature, Jan. 8, I880, vol. xxi., p. 237.

The Omori Shell Mounds. Nalure, April I5. I880, vol. xxi., p. $56 \mathrm{r}$.

Sir Wyville Thomson and Natural Selection. Naiure, Nov. II, I880, vol. xxiii., p. 32.

Black Sheep. Nalure, Dec. 30, I880, vol. xxiii., p. 193.

Movements of Plants. Nature, March 3, 1881, vol. xxiii., p. 409.

The Movements of Leaves. Nature, April 28, 188r, vol. xxiii., p. 603 .

Inheritance. Nature, July 21, I88 r, vol. xxiv., p. 257.

Leaves Injured at Night by Free Radiation. Nature, Sept. 15, 1881, vol. xxiv., p. 459.

The Parasitic Habits of Molothrus. Nature, Nov. 17, 1881, vol. xxv., p. 51,

On the Dispersal of Freshwater Bivalves. Nature, April 6, I882, vol. xxv., p. 529 .

The Action of Carbonate of Ammonia on the Roots of certain Plants. [Read March I6, I882.] Linn. Soc. Fourn. (Botany), vol. xix., 1882, pp. 239-261.

The Action of Carbonate of Ammonia on Chlorophyll-bodies. [Read March 6, 1882.] Linn. Soc. Fourn. (Botany), vol. xix., 1882, pp. 262-284.

On the Modification of a Race of Syrian Street-Dogs by Means of Sexual Selection. By W. Van Dyck. With a Preliminary Notice by Charles Darwin. [Read April 18, 1882.] Proc. Zoölog. Soc., 1882, pp. $367-370$. 
WORKS ON DARWINISM FOR FURTHER-REFERENCE.

\section{ENGLISH.}

Contributions to the Theory of Natural Selection. A. R. Wallace. Darwiniana. Prof. Asa Gray.

On the Origin of Species, or the Causes of the Phenomena of Organic Nature. Prof. Huxley.

The Scientific Evidences of Organic Evolution (London, 1882).

G. J. Romanes.

Man and Apes (Am. ed., 1874). St. George Mivart.

Animal Life as Affected by the Natural Conditions of Existence. Karl Semper.

Degeneration, a Chapter in Darwinism (London, 1880). E. R. Lankester.

Mind in the Lower Animals (London, 1879). Lindsay.

Animal Intelligence. G. J. Romanes.

The Fertilisation of Flowers (Transl., London, 1883, 669 pp.). Hermann Müler.

Inquiries into Human Faculty and its Development. Francis Galton.

Philosophical Discussions. Chauncey Wright.

On the Philosophic Aspects of Darwinism. G. H. Schneider : Der Thierischen Wille (xx. and 447 pp., Leipzig, 1880).

The Theory of Evolution of Living Things, and the Application of the Principle of Evolution to Religion. George Henslow.

Religion and Science. Joseph Leconte.

Natural Law, an Essay on Ethics. Edith Simcox.

The Theistic Argument, as Affected by Recent Theories. J. L. Diman.

What is Darwinism? Charles Hodge.

The Story of the Earth and Man. J. W. Dawson.

Winds of Doctrine, being an Examination of the Modern Theories of Atomism and Evolution (London, 1877). C. Elam.

On the Genesis of Species. St. George Mivart.

Lessons from Nature as Manifested in Mind and Matter. St. George Mivart.

Contemporary Evolution. St. George Mivart.

Contributions to the Natural History of the United States, vol. i., Essay on Classification; also Amer. Fourn. Sci., July, 1860. L. Agassiz. 
FOREIGN.

Beiträge zur Descendenz-Theorie (Leipzig, 1876). Georg Seidlitz.

Entwickelungsgeschichte des Menschen und der höheren Thiere Iste Hälfte (Leipzig, 1876). A. Kolliker.

Anthropogenie, Entwickelungsgeschichte des Menschen (Leipzig, 1874). E. Haeckel.

Die neuere Schöpfungsgeschichte (Leipzig, 1875). Arnold Dodel.

Die Verwandtschaftsbeziehungen der gegliederten Thiere (Wurtzburg, 1875). C. Semper.

Für Darwin (Leipzig, 1864)。 Fritz Müler.

Ueber die erste Entstehung organischen Wesen u. deren Spaltung in Arten (Berlin, 1866). A. Muller.

Zur Entwickelungstheorie (Jena, I876). Otto Zacharias.

Der Kampf der Theile in Organismus (Leipzig, 1881). W. Roux.

In Sachen Darwin's insbesondere contra Wigand (Stuttgart, 1874).

Gustav Jäger.

Études sur la sélection dans ses rapports avec l'héredité chez l'homme. P. Jacoby.

Der Darwinismus und seine Stellung in der Philosophie (Berlin, 1877). Eugen Dreher.

Philosophische Consequenzen der Lamarck-Darwin'schen Entwickelungstheorie (Leipzig and Heidelberg). Georg Von Gizycki.

Kant und Darwin, ein Beitrag zur Geschite der Entwickelungslehre (Jena, 1875). Fritz Schultze.

Die Darwin'schen Theorien und ihre Stellung zur Philosophie, Religion, und Morals (Stuttgart). Rudolf Schmid.

La Teoria di Darwin Criticamente Exposta, Biblioteca Scientifica Internationale (Milano, 1880). G. Canestrini.

Der Darwinismus und die Naturforschung Newtons und Cuviers (3 vols., 1874-7). A. Wigand.

Wahrheit und Irrthum in Darwinismus (Berlin, 1875). E. Von Hartmann.

Die Freiheit der Wissenschaft im modernen Staai (Berlin, 1877). R. Virchow.

Haeckelismus in der Zoőlogie (Hamburg, 1876). C. Semper.

Anti-Darwinistische Beobachtungen (Bonn, 1877). F. Michaelis.

A journal of highest ability devoted to evolution is Kosmos, Zeitschrift fur cinheilliche Weltanschaung auf Grund der Entwickelungslehre, in Verbindring mit Charles Darwin und Ernst Haekel, sowie einer Reihe hervorragenden Forscher auf den Gebielen des Darwinismus (monthly, 80 pp., since 1876). 



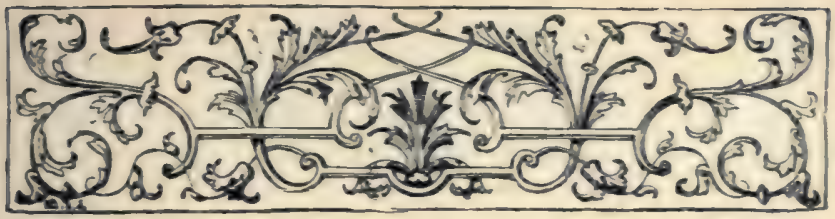

INDEX.

A

Abinger $\mathrm{Hall}, 242$

Aconcagua, 89

Adventure Island, 263

Agassiz, Louis, 272

Agonti, 49

Albermarle Island, I ro

Allen, Dr., 30

Amblyrhynchus, 108

America, 186

Amethyst Mountain, 184

Ant-eater, 49

Antennarius, I 76

Antuco, 93

Archseopterix, I93

Aristotle, 167

Armadillo, 49

Ascenium, 121

Aspalax, 44

Atavism, I8I

Atlantic cable, 184

Atoll, II 7

Azara, 45, 65

Azores, 122

\section{B}

Bahia, 28

Bahia Blanca, I04

Baker, Frank, I95, 250

Banda Oriental, I04

Bastile 170

Beagle, 5, 19, 263

Beagle Inlet, 80
Berkeley Sound, 78

Bibliography, 259

Biological Society, 195

Birgos, I 15

Biscacha, $5^{8}$

Bolas, 42

Botofogo Bay, 29

Brazil, 37

Buenos Ayres, 46, 49

Buffon, 168

Burmeister, Prof., 73

Butler, Dr., 2

Butterflies, 37 ; shower of, 69

C

Callao, $\mathrm{IO}_{3}$

Cape Horn, 70

Cape of Good Hope, 128

Cape Verde Islands, 22

Capybara, 43

Cattle, peculiar breed of, 67

Chacao, 87

Chamisso, II 4

Charles Island, III

Chatham, 107

Chile, 37

Chiloe, 87

Chonos Archipelago, 87

Cirripedia, 264

Cocoa-nut, II 5

Colorado River, 48

Concepcion, 90

Condor, 77

Confervae, 32 
Cope, E. D., $\mathrm{r}_{3}$

Cophias, 53

Copiapó, 96

Coral, $1 \times 7$

Coral-eating fish, II6

Cormorant, 8 I

Coseguina, 89

Crabs, 86 ; mimicry of, 176

Creation, 203

Crocodile, 55

Cuttle-fish, 25

Dagger, 4r

Dall, W. H., I95, 208

Darwin, birth, 2 ; school days, 2 ; religious feeling, 3 ; collections, 4; walks, 4-9; at Maer, 4-9; laboratory work, 5 ; university life, 6 ; nickname of, 6 ; wealth of, 6 ; vacation of, 9 ; as a hunter, Io ; college life, 12; books read by, 14 ; on slavery, 33 ; on birds, 88 ; works on coral, II 7, 26I ; appearance of, I 3I, 239; daily life of, I33; early papers of, 137 ; services to science, $\mathbf{I} 40$; conclusions, I4I ; publication of

$\therefore$ his great work, I43; birth of Darwinism, I44 ; botanical researches, 145 ; religious reticence, 147 ; buried in Westminster Abbey, 148; membership in societies, 149; a birthday gift, I5I ; honors, I52-I55 ; family, I56 memorial, 167; theory of, 184; memorial on, 195; doctrine of, Ig6; Children, 212 ; friends of, 212 ; death of, 213 ; philosophy of, $2 \mathrm{I} 4$; as an entomolngist, 228 ; home of, 239 ; letters of, 240 ; as a botanist, 244 ; bibliography of, 259 ; papers of, 268 ; foreign works on, 273

Darwin, E. G., 9ז

Darwinism, works on, 162, 272

Dawson, J. W., 272

Deer, 43
De Maillet, I68

Descent, I94

Desmodus, 33

Diman, J. L., 272

Diodon, 29

Doubleday, Mr., 38

Dover cliffs, 6,184

Dreher, Eugene, 273

Drouths, 64

Duncan, Dr., 6

Dust showers, 23

E

East Falkland Islands, 78

Edinburgh, 7

Ehrenberg, 23, 24

Egg collecting, 3

Egypt, I 86

Elater, 36

El Bramador, IO3

El Carmen, 47

Embryo, I9r

Emotions, 265

Eocene, 188

Epeira, web of, 39

Equus, 189

Evolution, 173

Extinction, 64, 76

F

Falmouth, 122

Fernando Noronha, 26, 27

Fire-fly, 36

Floating islands, 85

Flustra, 2, 8

Flying fish, 26, 34

Fossils, 68

Fuegians, 79

G

Galapagos, 32, ro6

Geographical distribution, 62

Geological Society, I25

Germany, I93

Giants, 79

Giant-weed, 8 I

Gill, Theo., I95 
Glaciers, 82

Goethe, I 70

Goode, Prof., I g6

Grant, Dr, 7

Gray, 172

Greenland, Igr

Greenwich, I24

Greyhound, I74

\section{II}

Haeckel, Ernst, 273

Hairless dog, 60

Hartman, Von E., 2'/3

Harvey, W. H., I68

Head, Sir F., Ior

Hecla, go

Henslow, Prof., I4

Hesperornis, I92

Herschel, Sir J., I68

Hibernation, 53. 54

Hill, Major, Io

Hipparion, 188

Hippocampus, 47

Hodge, Charles, 272

Holcodont, 193

Holder, J. B., I3

Horner, L., 8

Horse, 62, 66, I 88

Hot springs, 84

Humboldt, 17, 172

Huxley, I 74

Hydrocharus, 43

\section{I}

Iceberg, 82

Incas, $\mathbf{I} 88$

Indians, 5 I, 56

Insectivorous plants, 242

\section{$\mathrm{J}$}

Jacoby, P., 273

James Islands, Iog

Jaguar, 44, 65

Jelly-fish, $58,7 \mathrm{r}$

Jenyns, Rev. L., 263

Jungle fowl, 173

\section{K}

Keeling Island, II4

Kolliker, Prof., 273

L.

Lagostomus, 58

Lamarck, 44, I7 I

Lambert, I68

Lampyris, 36

Lancaster, E. R., 272

La Place, I 68

La Plata, 53

Lianes, 34

Lightning, 45

Lima, ros

Linnæean Society, I 26

Lizards, 53, I08

Llama, 72

Lobster, 195

Locusts, I00

Luxan, ror

Lyell, Sir Chas., 6r, I7I

\section{M}

Mackintosh, Sir John, I I, I7

Macrauchenia, 73, 104

Macrocystis, $8 \mathrm{r}$

Malay, II $_{5}$

Maldonado, 40

Marsh Prof., 62

Mathews, P., 200

Mauritius, 120

Megatherium, 49

Mendoza, IO2

Megalonyx, 49

Mesohippus, I89

Michaelis, 273

Mimics, 53, 79

Minerals, 7

Mines, 84

Miohippus, 189

Mivart, St. G., 27 I

Monboddo, I 70

Monkeys, 35

Monte Video, 43, 46

Moresby, Capt., I Io

Mould, 265 
Muller, F., 273

Murderers, 40

Mylodon, 49

Myopotamus, 87

\section{N}

Neptune, 28

Noddy, 26

Nummulite, $\mathbf{1} 86$

O

Octopus, 24, 3 I

Odontornithes, I9I

Oken, $\mathbf{I} 70$

Orchid, 265

Origin of species, 264

Orohippus, Igo

Osorno, 87

Ostrich, 42, 5I

Otter, 8I

Owen, Prof., 49

Owen, Sir R., 172 .

\section{$\mathrm{P}$}

Paleozoic, 180

Pampas, 6I

Pander, 170

Papilio, 37

Parane, 59

Parrot-fish, II6

Patagonia, 72

Penguin, 39

Peru, I04

Philosophy, 218

Phosphorescence, 70

Planarian, 35

Plata, 39

Pliocene, 189

Polyborus, 45

Porpoise, 39

Portillo Pass, 97

Porto Praya, 24

Powell, J. W., 195, 214

Protococcus, 98

Pteranodon, 44

Puma, 85, 86

Pyramid, 186

Pyrophorus, 30
Plinian Society, I

Pernambuco, I2I

Philosophical Society of Cam. bridge, 124

\section{Q}

Quail, 43

Quiriquina Island, 9r

$\mathrm{R}$

Ramsay, Prof., 186

Razor clam, 99

Red snow, 98

Reefs, barrier, $\mathrm{II}_{7}$

Reefs, coral, II7, 264

Reptiles, I93

Rhea, 52

Rhizopods, 184

Ribeira Grande, 23

Riley, C. V., 228

Rio Negro, 33, 47

Rio Tercero, 59

Robber-crab, 27

Romanes, G. J., 272

Rosas, Gen., 55

Roux, W., 273

Royal navy, 17

Royal Society, 264

Ruins, 85

Reef structures, II 9

Royal Academy, 125

Rhea Americanus, I26

\section{$\mathrm{S}$}

Sacred tree, $4^{8}$

Salt lake, 48

San Carlos, 86

San Carlos Bay, 89

San Lorenzo, IO4

Santa Cruz, 5I, 73

Santa Fé, 60

Santa Maria, 94

Sarandis, 67

Sargassum, 176

Scarus, 116

Schleiden, 170

Schmidt, R., 273

Schultze, F., I70, 273 
Schwann, 170

Scott, Sir W., S

Seals, 39

Sea-horse, 47

Sea-sickness, 3I

Sea-slug, 24

Sea spiders, 35

Sedgwick, I3

Seeds, Iso

Semper, K., 272

Sharks, 27

Sorbonne, 170

Spencer, 172

Starling, 45

St. Hilaire, I 70

St. Jago, 27, 73

Stokes, Lord, 2 I

Stone forest, IS+

St. Helena, I20

St. Paul's Rocks, 26

Strata, 184

Survey, 40 .

Symonds, Sir W., 27

$\mathrm{T}$

Tahiti, II3

Talcahuana, gI

Teneriffe, $\mathrm{x} 7$

Tern, 26

Terra del Fuego, 32

Tertiary, 186

Thales, 168

Tidal wave, 92

Torpedo, 183

Toxodon, 50

Trotters, 173
True, Fred. W., I95, $25^{8}$

Tucutuco, 44

Turtles, II4

U

Uruguay, 59

Uspullata, IOI

V

Valdivia, 90

Valparaiso, 67, 83

Vampire, 33

Variability, I $8 \mathrm{r}$

Varieties, 173

Von Baer, 170

Von Mohl, 170

w

Wallace, Alfred, 172

Walleechu, 49

Ward, Lester F., I95, 242

Wills, Dr., 200

Wolf, I70

Woodhouse, 9

Wright, C., 168, 272

I

Yale College, 192

Yaquil, 85

Youmans, E. L。, 172

Z

Zacharias, Otto, 273 



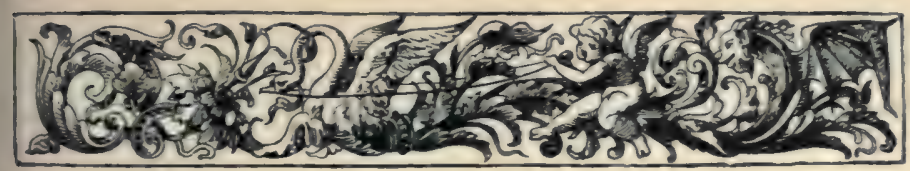

\section{Iheroes of the Iflations.}

EDITED BY

EVElyn ABbotT M.A., Fellow of Balliol College, Oxford.

A SERIES of biographical studies of the lives and work of a number of representative historical characters about whom have gathered the great traditions of the Nations to which they belonged, and who have been accepted, in many instances, as types of the several National ideals. With the life of each typical character will be presented a picture of the National conditions surrounding him during his career.

The narratives are the work of writers who are recognized authorities on their several subjects, and, while thoroughly trustworthy as history, will present picturesque and dramatic "stories" of the Men and of the events connected with them.

To the Life of each "Hero" will be given one duo. decimo volume, handsomely printed in large type, provided with maps and adequately illustrated according to the special requirements of the several subjects. The volumes will be sold separately as follows :

Cloth extra

Half morocco, uncut edges, gilt top

\$1 50

Large paper, limited to 250 numbered copies for

I 75

subscribers to the series. These may be obtained in sheets folded, or in cloth, uncut edges 
The first group of the Series will comprise twelve volumes, as follows:

Nelson, and the Naval Supremacy of England. By W. CLARK RusseLL, author of "The Wreck of the Grosvenor," etc. (Ready April 15, I89o.)

Gustavus Adolphus, and the Struggle of Protestantism for Existence. By C. R. L. Fletcher, M.A., late Fellow of All Souls College, Oxford.

Pericles, and the Golden Age of Athens. By Evelyn Aвbott, M.A., Fellow of Balliol College, Oxford.

Alexander the Great, and the Extension of Greek Rule and of Greek Ideas. By Prof. Benjamin I. Wheeler, Cornell University.

Theoderic the Goth, the Barbarian Champion of Civilization. By THOMAS Hodgkin, author of "Italy and Her Invaders," etc.

Charlemagne, the Reorganizer of Europe. By Prof. GEORge L. BURR, Cornell University.

Henry of Navarre, and the Huguenots in France. By P. F. Willert, M.A., Fellow of Exeter College, Oxford.

William of Orange, the Founder of the Dutch Republic.

By Ruth Putnam.

Cicero, and the Fall of the Roman Republic. By J. L. Strachan Davidson, M.A., Fellow of Balliol College, Oxford.

Louis XIV., and the Zenith of the French Monarchy. By ArTHUR Hassall, M.A., Senior Student of Christ Church College, Oxford.

Sir Walter Raleigh, and the Adventurers of England.

By A. L. Smith, M.A., Fellow of Balliol College, Oxford.

Bismarck. The New German Empire : How It Arose; What It Replaced; And What It Stands For. By JAMEs SimE, author of "A Life of Lessing," etc.

To be followed by:

Hannibal, and the Struggle between Carthage and Rome.

By E. A. Freeman, D.C.L., LL.D., Regius Prof. of History in the University of Oxford.

Alfred the Great, and the First Kingdom in England. By F. YORK Powell, M.A., Senior Student of Christ Church College, Oxford.

Charles the Bold, and the Attempt to Found a Middle Kingdom. By R. Lodge, M.A., Fellow of Brasenose College, Oxford.

John Calvin, the Hero of the French Protestants. By OwEN M. EDWARDS, Fellow of Lincoln College, Oxford.

Oliver Cromwell, and the Rule of the Puritans in England.

By Charles Firth, Balliol College, Oxford.

Mariborough, and England as a Military Power.

By C. W. C. Oman, A.M., Fellow of All Souls College, Oxford.

Julius Cæsar, and the Organization of the Roman Empire.

By W. IVARde Fowler, M.A., Fellow of Lincoln College, Oxford.

G. P. PUTNAM'S SONS

NEW YORK

27 AND 29 WEST TWENTY-THIRd STREET
LONDON

27 King William Street, Strand 


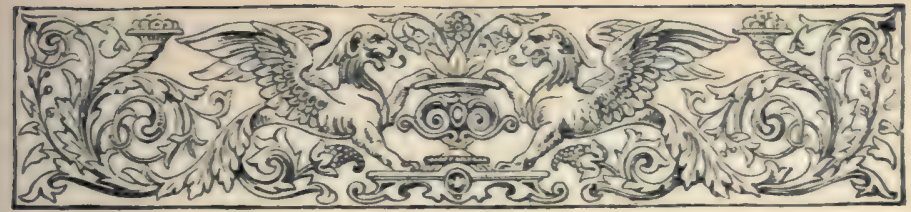

\section{The Ftory of the filations.}

Messrs. G. P. PUTNAM'S SONS take pleasure in announcing that they have in course of publication, in co-operation with $\mathrm{Mr}$. T. Fisher Unwin, of London, a series of historical studies, intended to present in a graphic manner the stories of the different nations that have attained prominence in history.

In the story form the current of each national life is distinctly indicated, and its picturesque and noteworthy periods and episodes are presented for the reader in their philosophical relation to each other as well as to universal history.

It is the plan of the writers of the different volumes to enter into the real life of the peoples, and to bring them before the reader as they actually lived, labored, and struggled - as they studied and wrote, and as they amused themselves. In carrying out this plan, the myths, with which the history of all lands begins, will not be overlooked, though these will be carefully distinguished from the actual history, so far as the labors of the accepted historical authorities have resulted in definite conclusions.

The subjects of the different volumes have been planned to cover connecting and, as far as possible, consecutive epochs or periods, so that the set when completed will present in a comprehensive narrative the chief events in 
the great Story of THE Nations; but it is, of course, not always practicable to issue the several volumes in their chronological order.

The "Stories" are printed in good readable type, and in handsome $12 \mathrm{mo}$ form. They are adequately illustrated and furnished with maps and indexes. Price, per vol.. cloth, \$1.50. Half morocco, gilt top, \$1.75.

The following volumes are now ready (January, I89I) :

THE STORY OF GREECE. Prof. JAs. A. Harrison.

" " " ROME. ARTHUR GILMAN.

" " "THE JEWS. Prof. JAMES K. Hosmer.

" " " CHALDEA. Z. A. RAGozIN,

" " "GERMANY. S. BARING-GoUld.

" " " NORWAY. HJalmar H. BoYesen.

" " "SPAIN. Rev. E. E. and SUSAN Hai.e,

" " "HUNGARY. Prof. A. VAMBERY.

" " "CARTHAGE. Prof. AlFred J. Church.

" " "THE SARACENS. ARTHUR GILMAN.

" " "THE MOORS IN SPAIN. STANLEY LANE-Poole.

" " $"$ THE NORMANS. SARAH ORNE JEWETT.

" " " PERSIA. S. G. W. BENJAMIN.

" " " ANCIENT EGYPT. Prof. GEo. RAwlinson.

" " "ALEXANDER'S EMPIRE. Prof. J. P. MAHAFFY.

" " "ASSYRIA. Z. A. RAGOZIN,

" " "THE GOTHS. HeNRY BradLey.

" " " "IRELAND. Hon. EMily Lawless.

" " "TURKEY. STANLey Lane-Poole,

" " " $"$ MEDIA, BABYLON, AND PERSIA. Z. A. RAGozIN.

" " " MEDIAVAL FRANCE. Prof. Gustav Masson,

" " "HOLLAND. Prof. J. THOROLD ROGERs.

" " " MEXICO. Susan Hale.

" " " $"$ "HCENICIA. Prof. GEO. RAwlinson.

" " " THE HANSA TOWNS. HELEN ZIMMERN.

" " " $"$ EARLY BRITAIN. Prof. AlFRED J. CHURCH.

" " "THE BARBARY CORSAIRS. STANLEY LANE-POOLE.

" " " RUSSIA. W. R. MORFILL.

" " " THE JEWS UNDER ROME. W. D. MORRISON.

" " "SCOTLAND. JOHN MACKINTOSH.

" " “ SWITZERLAND. R. STEAD and Mrs. ARnold Hug,

Now in Press for immediate issue:

THE STORY OF PORTUGAL. H. MoRse Stephens.

" " "VEDIC INDIA. Z. A. RAGOZIN.

" " " $"$ THE THIRTEEN COLONIES. HELEN A. SMITH.

" " "W WALES AND CORNWALL. OWEN M. EDWARDS.

" " " CANADA. A. R. MACFARLANE. 
PUBLICATIONS OF G. P. PUTNAM'S SONS

Robert Fulton and Steam Navigation. Ву Тноs. W. Knox, editor of "The Travels of Marco Polo," author of "Boy Travellers in the East," etc., etc. One large I2mo volume, profusely illustrated . . . . . . \$1 75

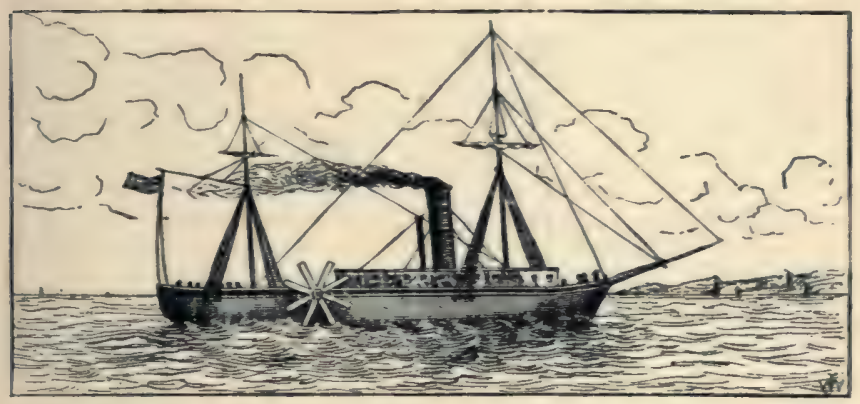

This book tells the story of a life of constant activity and usefulness, and describes the rise and progress of steam navigation in a manner most remarkable and clear. It is free from technical terms of all description, and is written in that charmingly narrative and picturesque form for which Mr. Knox is so justly famous.

The book is composed of 500 pages, and contains 82 elegant engravings, which go to emphasize its usefulness.

The early struggles of Fulton to get recognition for his inventions, his perseverance, and his dogged determination to succeed, are depicted forcefully and sympathetically. All the great ocean, war, and river steamers of the century, their principles of construction, the gradual evolution of speed by means of improved application of the original idea, and the development of the original crude machinery, are described and exemplified by numerous illustrations.

G. P. PUTNAM'S SONS, New York AND LoNdoN. 
Life of Abraham Lincoln. By NOAH BRooks. Crown octavo, with many illustrations . . . . \$1 75

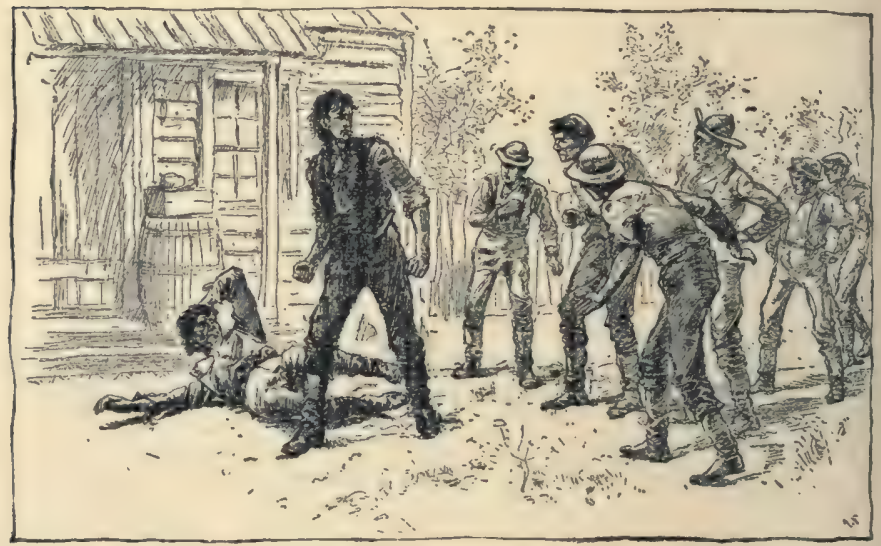

LINCOLN'S WRESTLE WITH ARMSTRONG.

(Reduced from "Life of Abraham Lincoln.")

"In writing this brief biography, I have been moved by a desire to give the generation of young people, who will never know aught of Abraham Lincoln but what is traditional, a life-like picture of the man as many men knew him. . . Many things relating to his early life herein set down were derived from his own lips, often during hours of secluded companion. ship."-From Author's Preface.

"An excellent and timely book."-New Albany Ledger.

"An admirably written book."-Buffalo Christian Advocate.

"It is a capital book."-Pittsburgh Chronicle.

"A more interesting biography we have not read."-Hartford Times.

G。 P. PUTNAM'S SONS, NEW YORK AND LONDON 


\section{The Life of George Washington Studied Anew. By}

EDWARD EVERETT HALE, author of "Man without a Country," "Ten Times One is Ten," etc., etc. Large 12 mo. Fully illustrated. In the Library of American Biography. . . . . . ... \$ 75

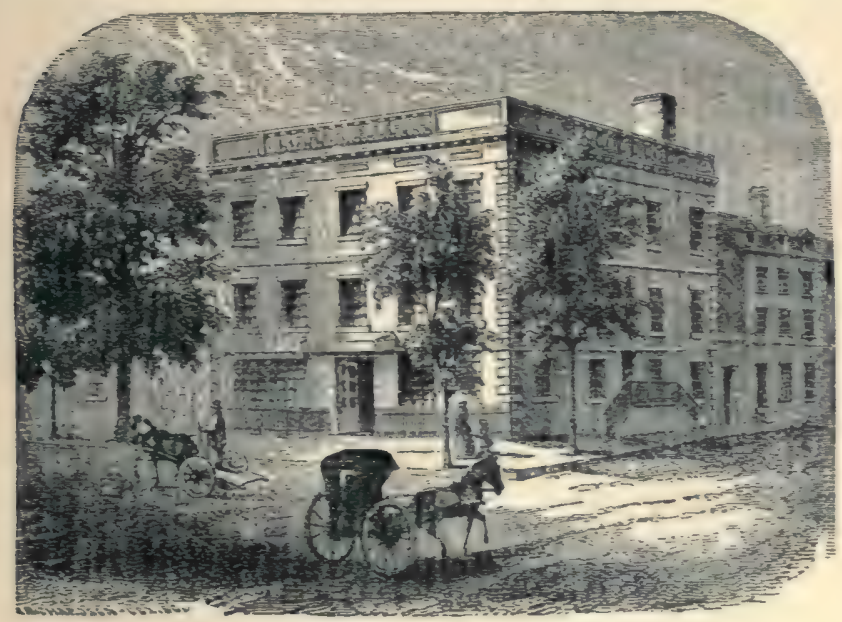

FIRST PRESIDENTIAL MANSION, FRANKLIN SQUARE, NEW YORK.

(From "Life of George Washington.")

"Mr. Hale, in this volume, written though it be in a quiet and subdued manner, brings us, as it were, closer to that illustrious one every man, woman, and child in this country should worship."-1. I. Times.

“. . As the reader of this book will learn, Washington left, arranged in careful order, perhaps more materials for his biography than any man of his century; but a certain habit of deifying him has thus far prevented writers of his life from approaching the study of the man . . It has been my aim, using chiefy in my narrative the diaries and letters of the man himself, to present to the new generation of Americans, the human Washington in such a way that ther may have some conception of the man and of the advantages and the disadvantages with which he worked through his great career."-Extrad from -A uthor's Preface.

G. P. PUTNAM'S SONS, NEW YORK AND LoNdoN. 
HISTORIC GIRLS : Stories of girls who have influenced the history of their times. By E. S. Brooks. Profusely illustrated . . . . . . . . . . . \$2 00

In these progressive days when so much energy and discussion are devoted to what is termed equality and the rights of women, it is well to remember that there have been in the distant past women, and girls even, who by their actions and endeavors proved themselves the equals of the men of their time in valor, shrewdness, and ability.

This volume seeks to tell for the girls and boys of to-day the stories of some of their sisters of the long ago-girls who by eminent position or valiant deeds became historic even before they had passed the charming season of girlhood.

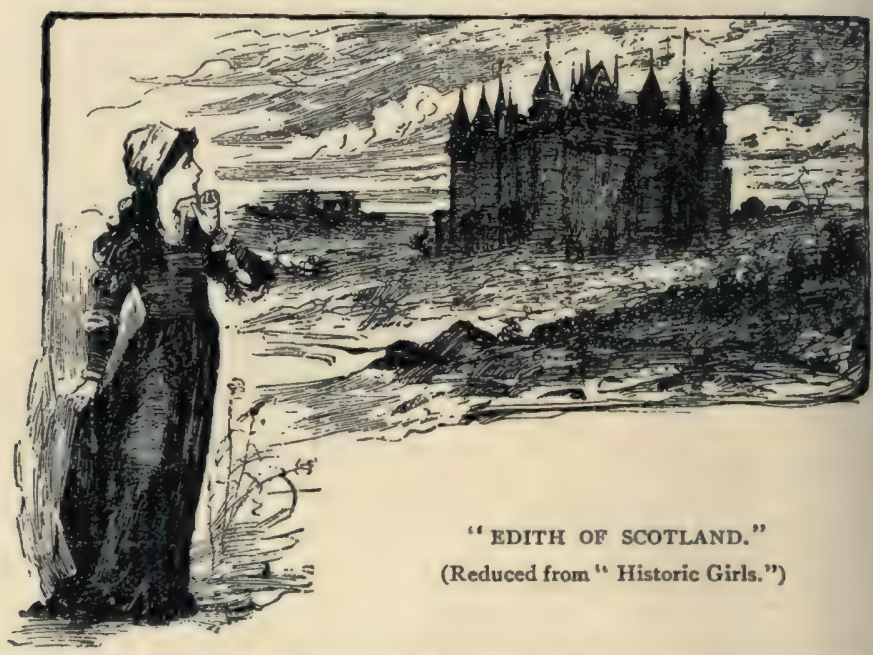

Their stories are fruitful of varying lessons ; for some of these historic girls were wilful as well as courageous, and mischievous as well as tender-hearted.

Contents of HISTORIC GIRLS : Zenobia of Palmyra, the Girl of the Syrian Desert ; Helena of Britain, The Girl of the Essex Fells; Pulcheria of Constantinople, The Girl of the Golden Horn; Clotilda of Burgundy, The Girl of the French Vineyards; Woo of Hwang-ho, The Girl of the Yellow River; Edith of Scotland, the Girl of the Norman Abbey; Jacqueline of Holland, The Girl of the Land of Fogs; Catarina of Venice, The Girl of the Grand Canal; Theresa of Avila, The Girl of the Spanish Sierras: Elizabeth of Tudor, The Girl of the Hertford Manor: Christina of Sweden, The Girl of the Northern Fiords : Ma-ta-oka of Pow-ha-tan, The Girl of the Virginia Forests.

$$
\text { G. P. PUTNAM'S SONS, NEW YoRK AND LoNDON. }
$$


0 






\section{PLEASE DO NOT REMOVE CARDS OR SLIPS FROM THIS POCKET}

\section{UNIVERSITY OF TORONTO LIBRARY}

$\mathrm{QH}$

31

D2H65
Holder, Charles Frederick Charles Darwin

Biological

a Micdical

$\cdots$ 
16.

fer 